\title{
‡USGS
}

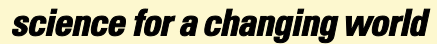

Prepared in cooperation with the U.S. Fish and Wildlife Service

\section{Species Accounts for the Alamosa/Monte Vista/Baca National Wildlife Refuge Complex}

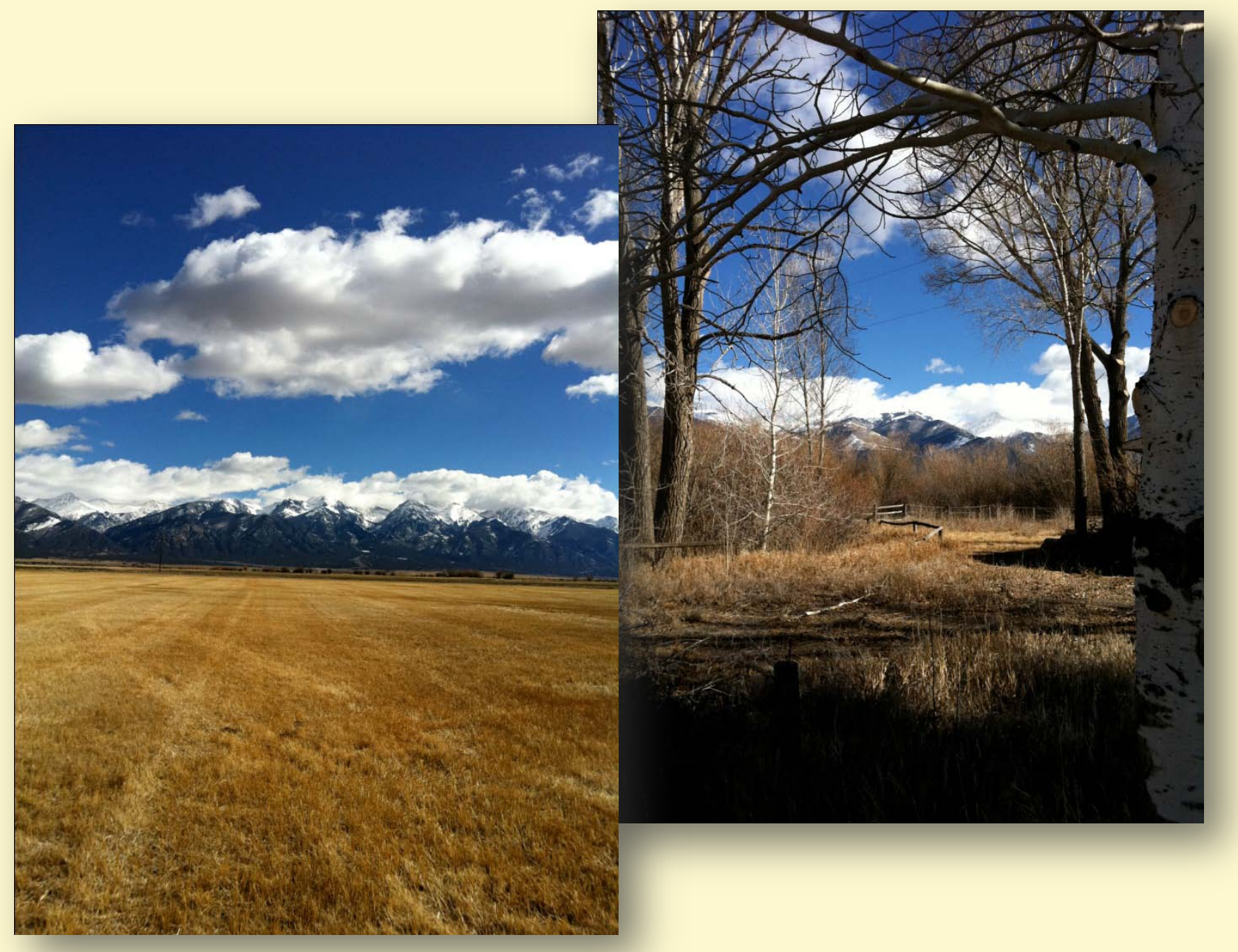

Open-File Report 2011-1285

U.S. Department of the Interior

U.S. Geological Survey 
Cover photographs: Baca National Wildlife Refuge, courtesy of Laura Ellison. 
Prepared in cooperation with the U.S. Fish and Wildlife Service

\section{Species Accounts for the Alamosa/Monte Vista/Baca National Wildlife Refuge Complex}

By Laura E. Ellison

Open-File Report 2011-1285

U.S. Department of the Interior

U.S. Geological Survey 


\section{U.S. Department of the Interior \\ KEN SALAZAR, Secretary}

\section{U.S. Geological Survey \\ Marcia K. McNutt, Director}

U.S. Geological Survey, Reston, Virginia 2011

For product and ordering information:

World Wide Web: http://www.usgs.gov/pubprod

Telephone: 1-888-ASK-USGS

For more information on the USGS-the Federal source for science about the Earth, its natural and living resources, natural hazards, and the environment:

World Wide Web: http://www.usgs.gov

Telephone: 1-888-ASK-USGS

Suggested citation:

Ellison, L.E., 2011, Species accounts for the Alamosa/Monte Vista/Baca National Wildlife Refuge Complex: U.S. Geological Survey Open-File Report 2011-1285, 195 p.

Any use of trade, product, or firm names is for descriptive purposes only and does not imply endorsement by the U.S. Government.

Although this report is in the public domain, permission must be secured from the individual copyright owners to reproduce any copyrighted material contained within this report. 


\section{Contents}

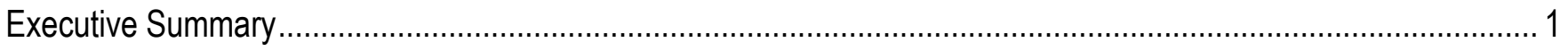

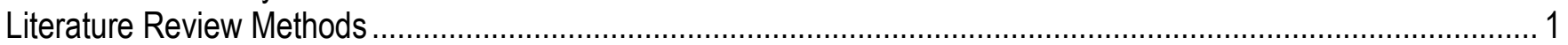

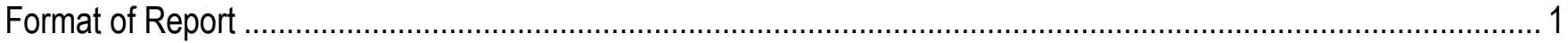

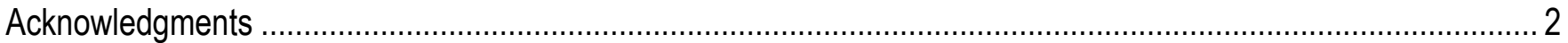

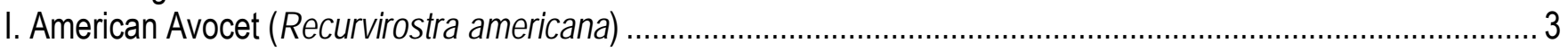

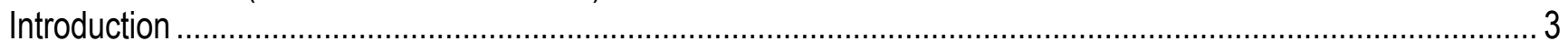

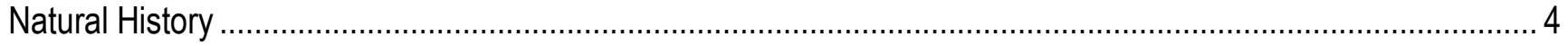

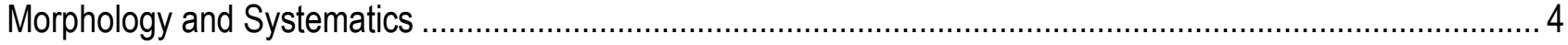

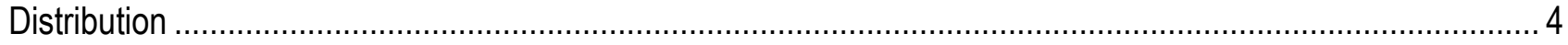

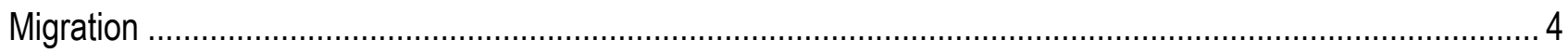

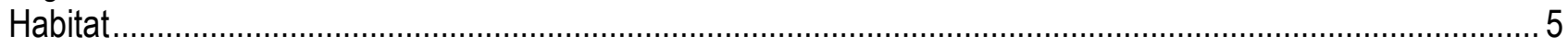

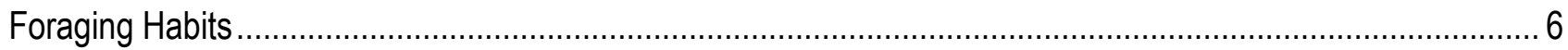

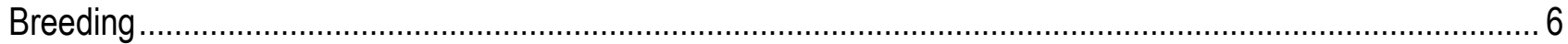

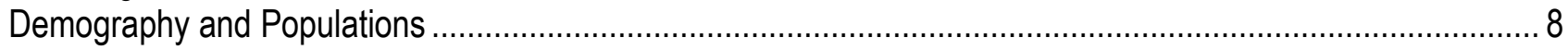

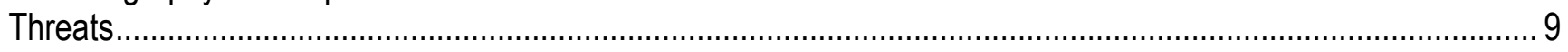

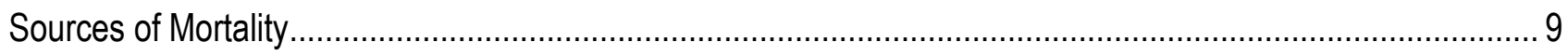

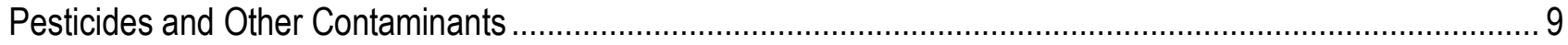

Loss and Degradation of Wetlands ................................................................................................. 11

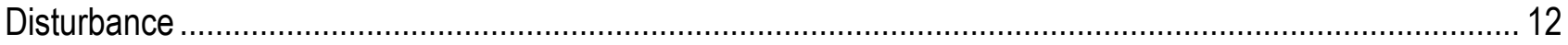

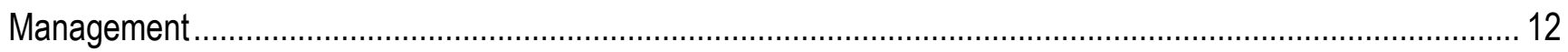

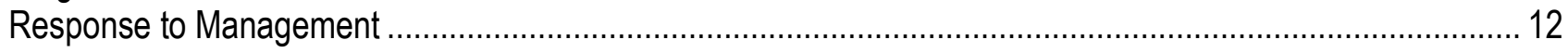

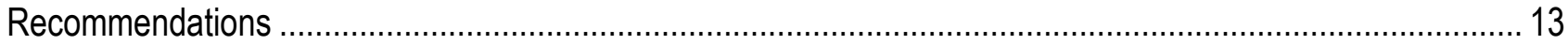

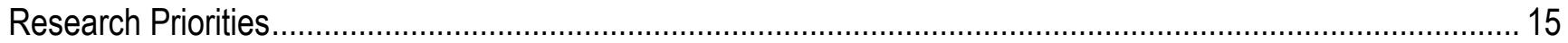

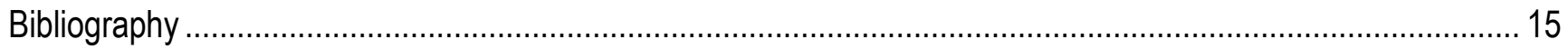

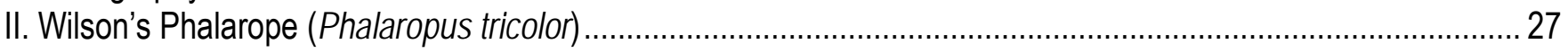

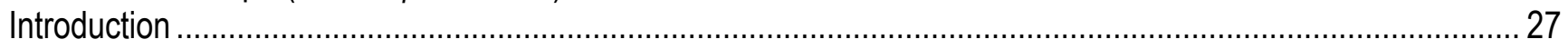

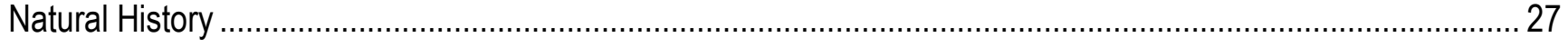

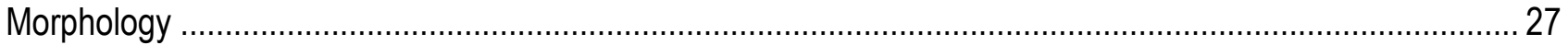

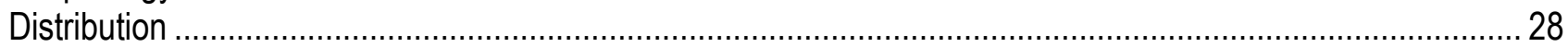

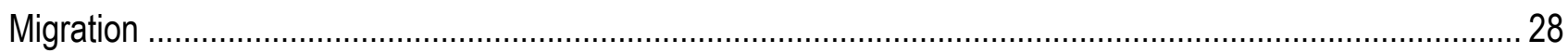

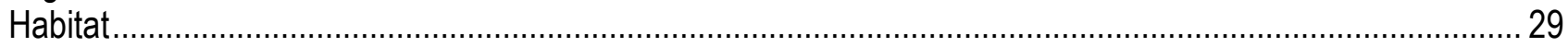

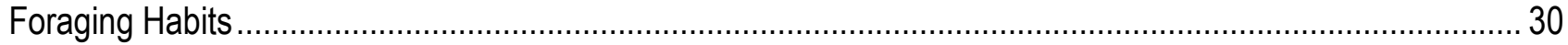

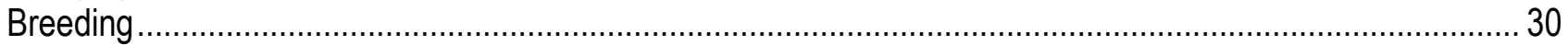

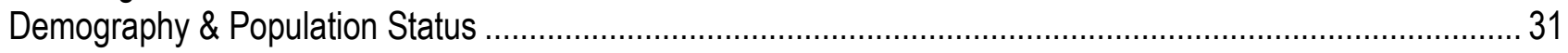

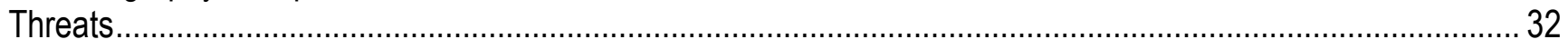

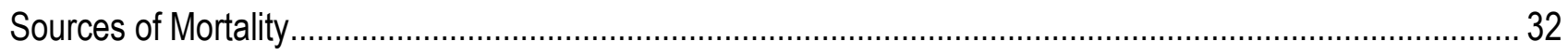

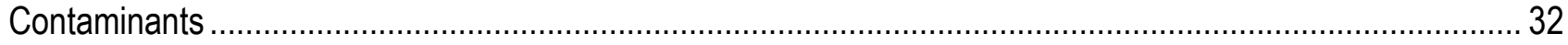

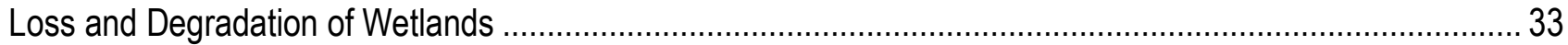

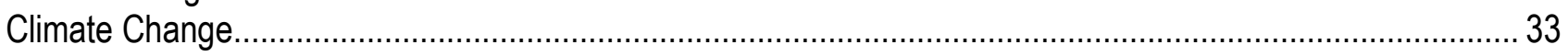

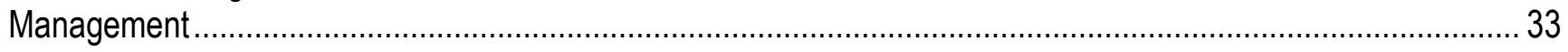

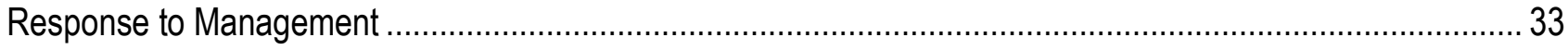

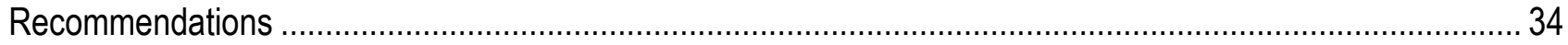

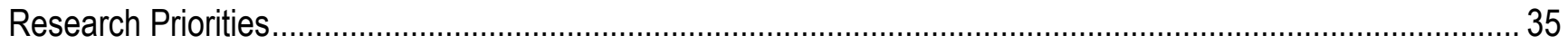

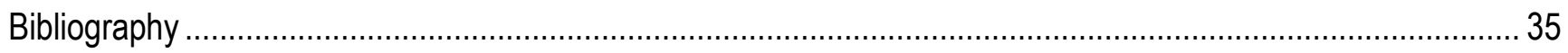

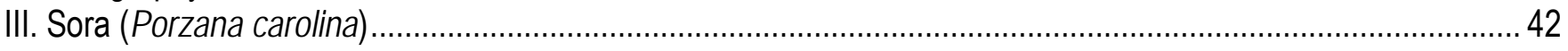

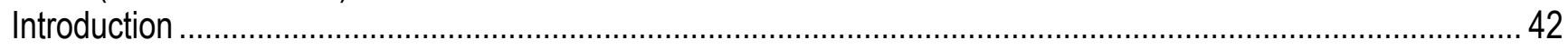




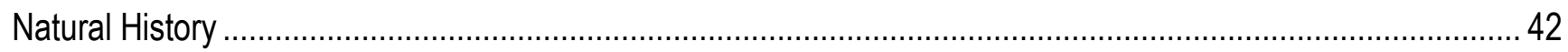

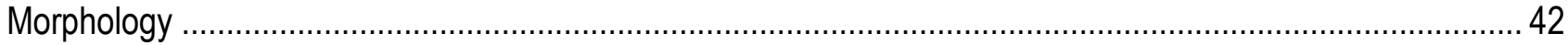

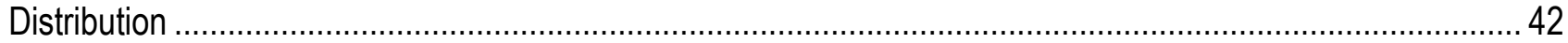

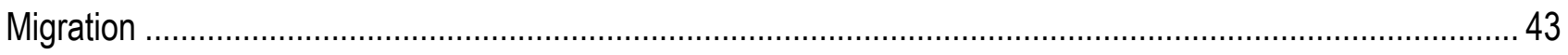

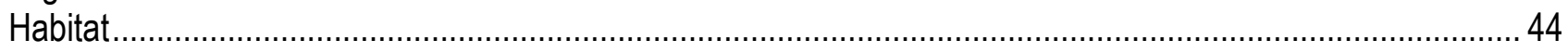

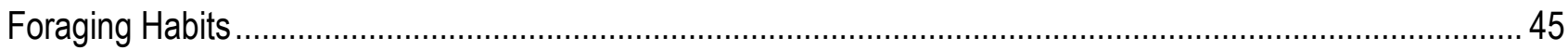

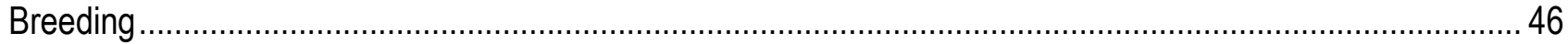

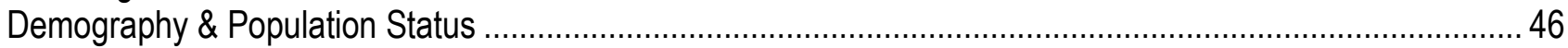

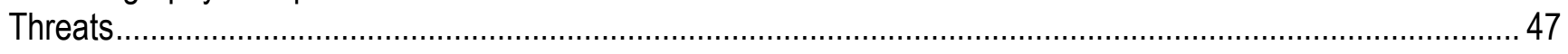

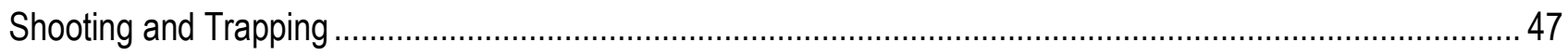

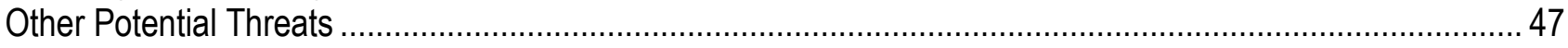

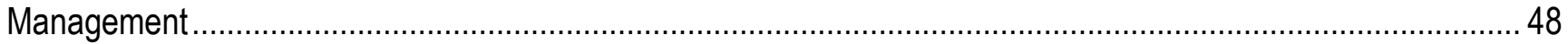

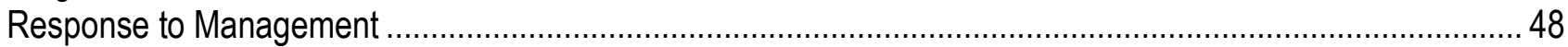

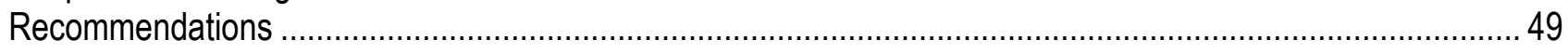

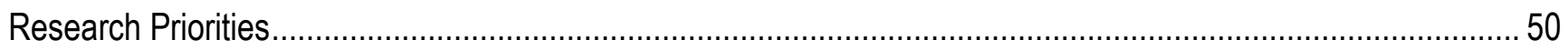

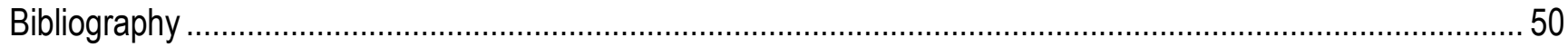

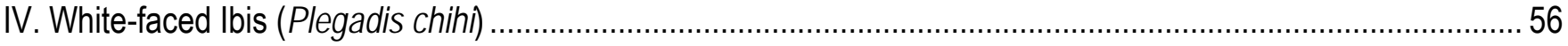

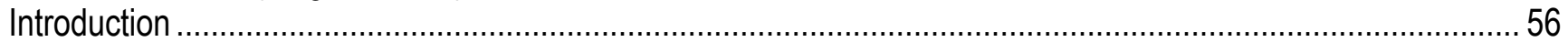

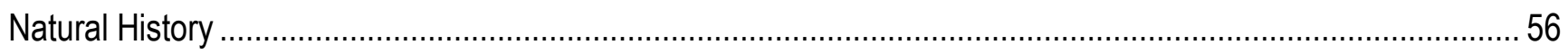

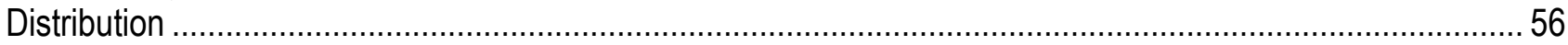

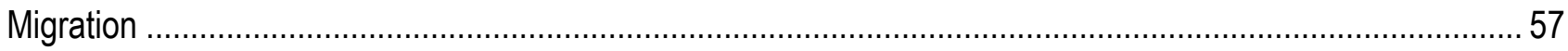

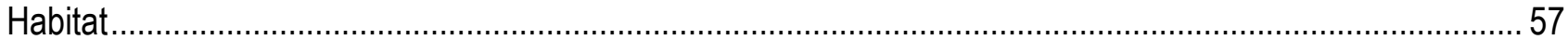

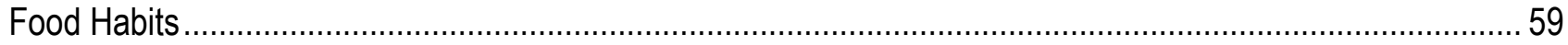

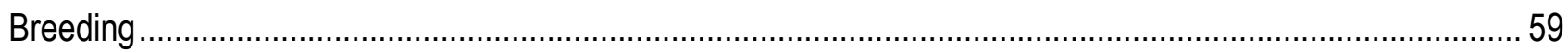

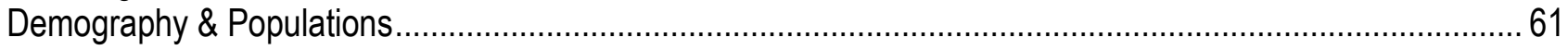

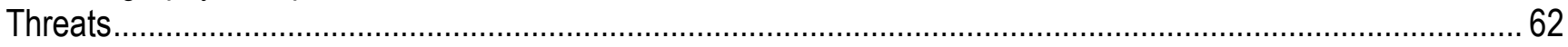

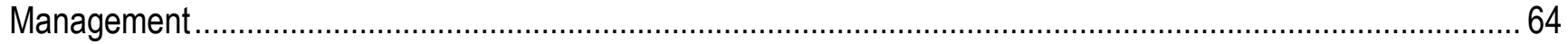

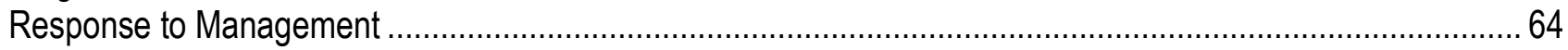

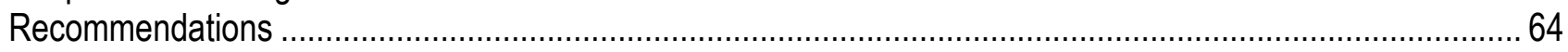

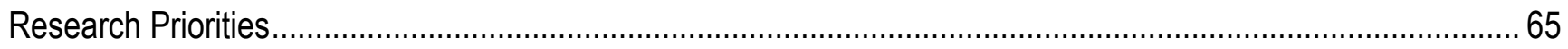

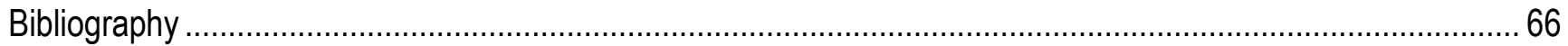

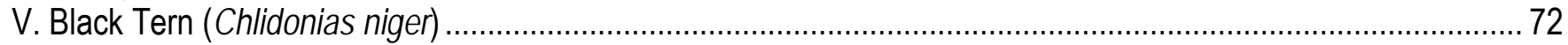

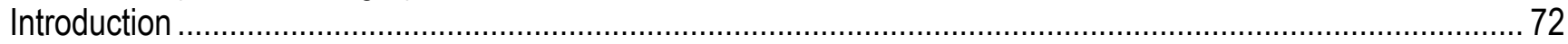

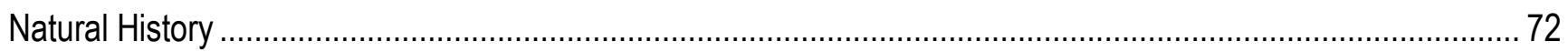

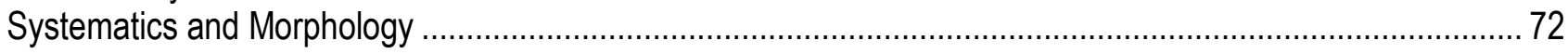

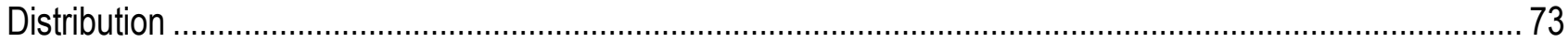

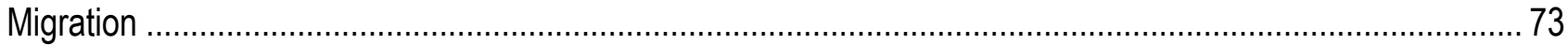

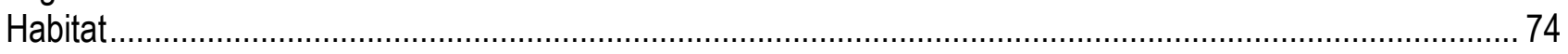

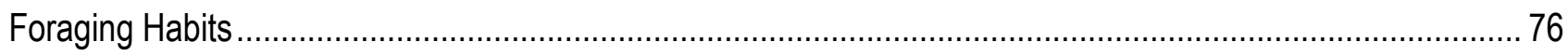

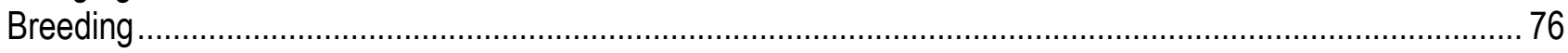

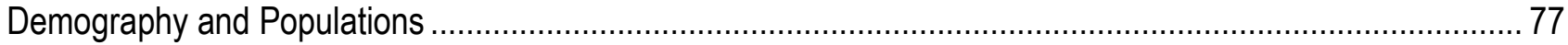

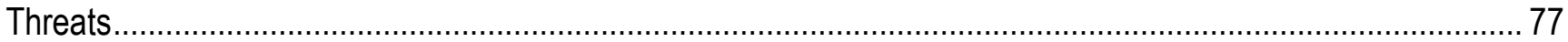

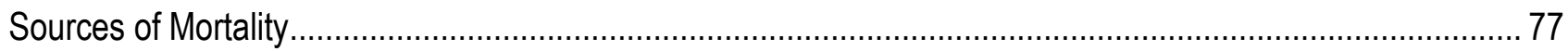

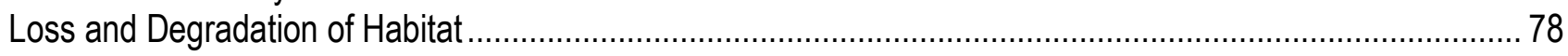

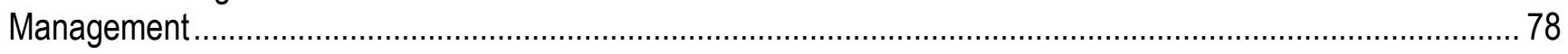

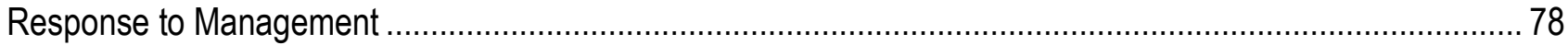

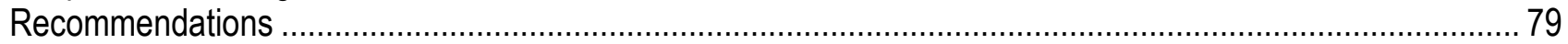

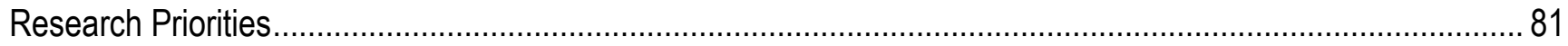




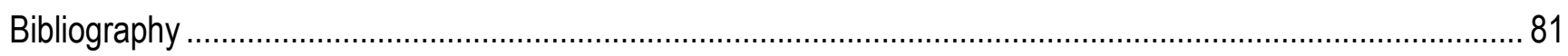

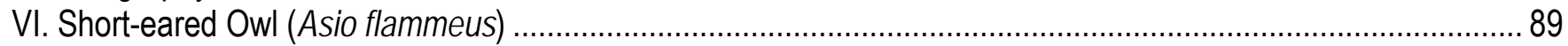

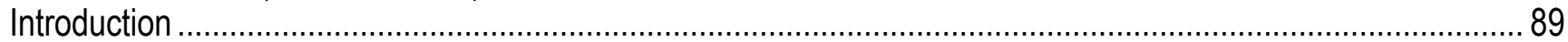

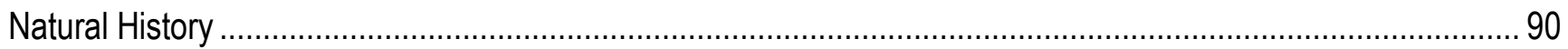

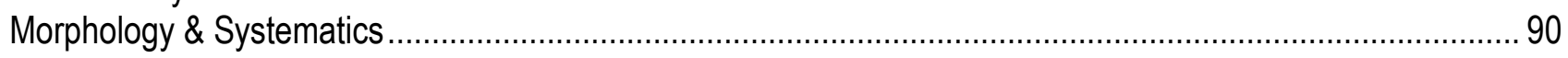

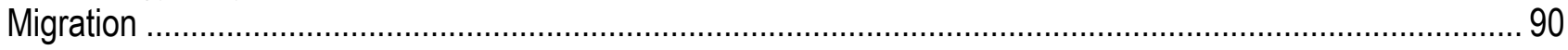

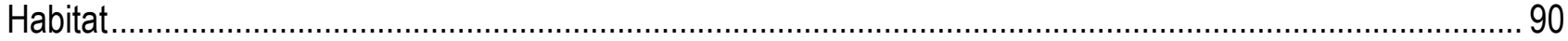

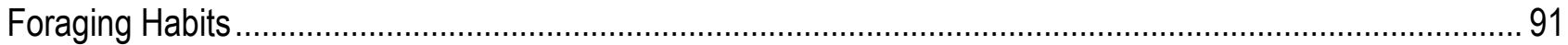

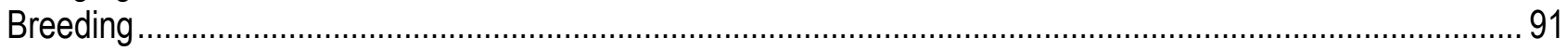

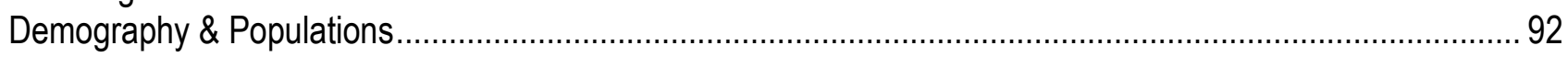

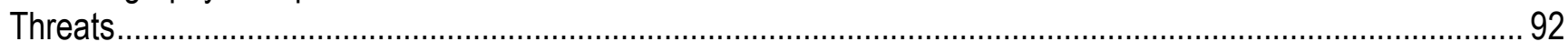

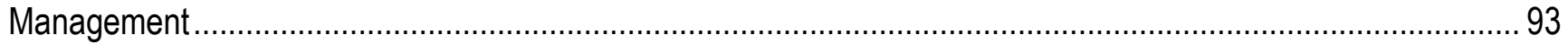

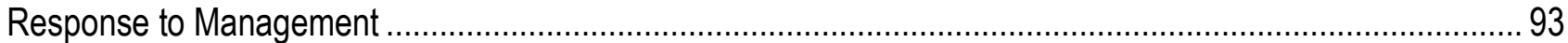

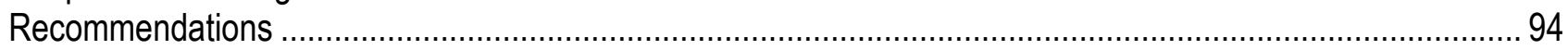

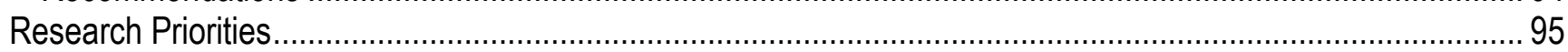

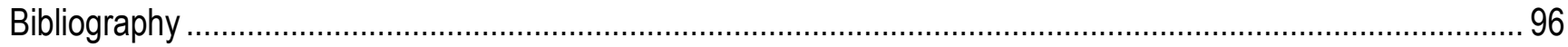

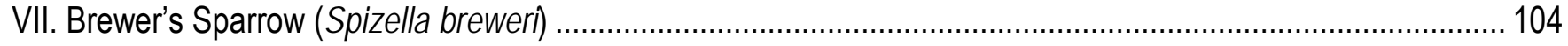

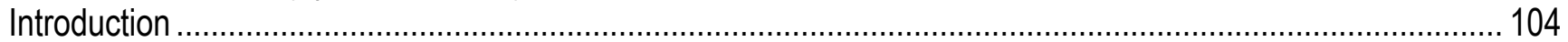

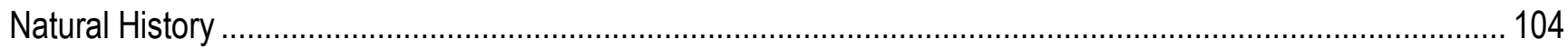

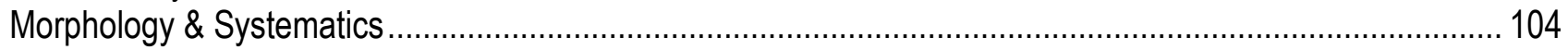

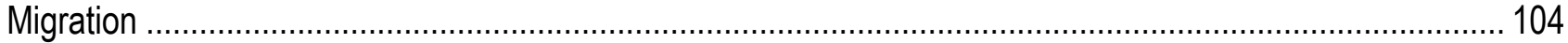

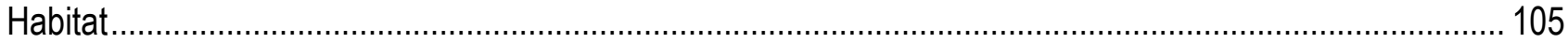

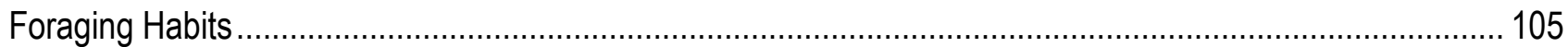

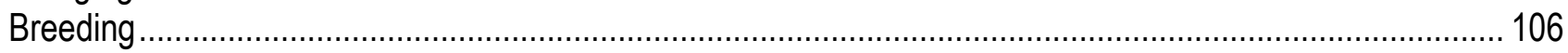

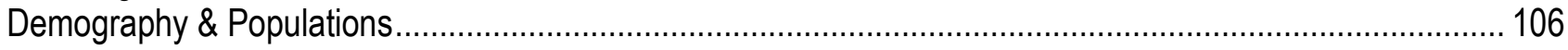

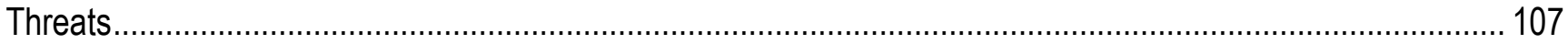

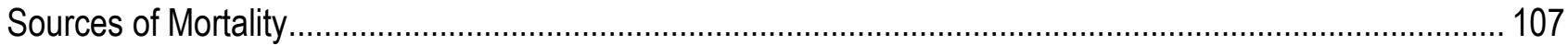

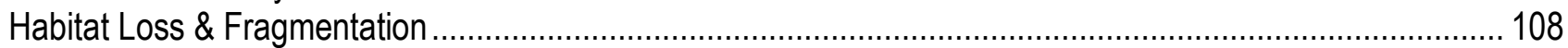

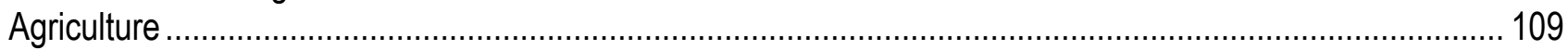

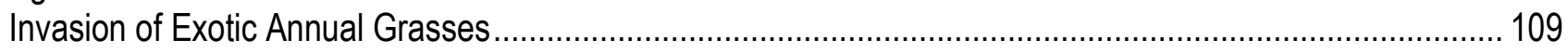

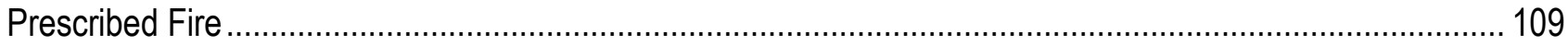

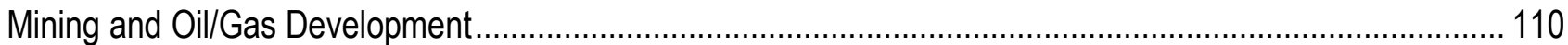

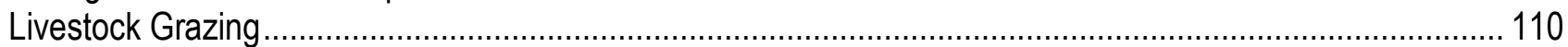

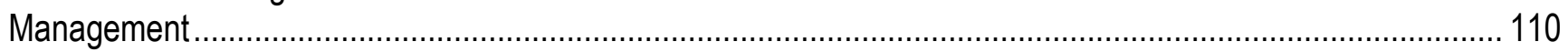

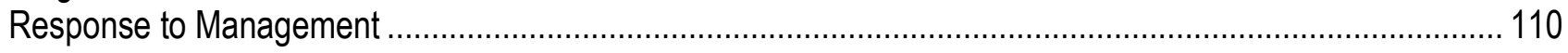

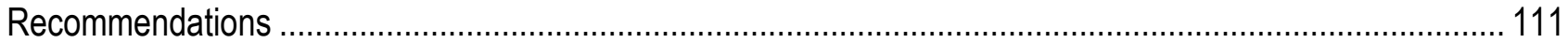

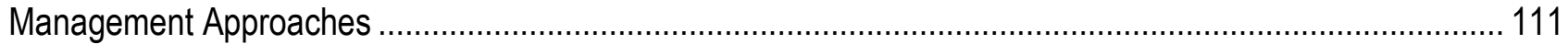

Research Priorities and Information Needs ....................................................................................... 112

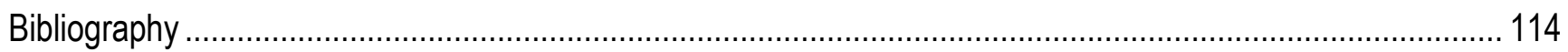

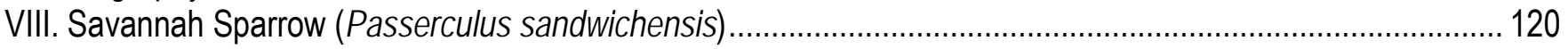

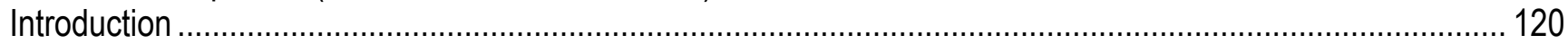

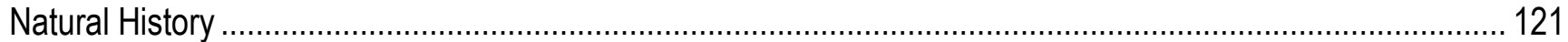

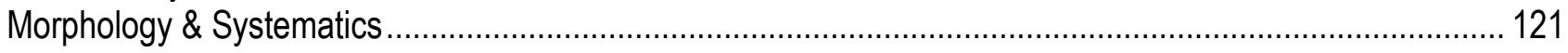

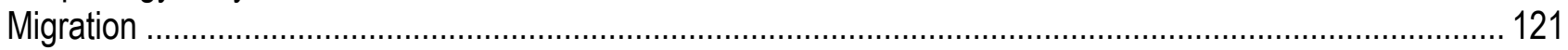

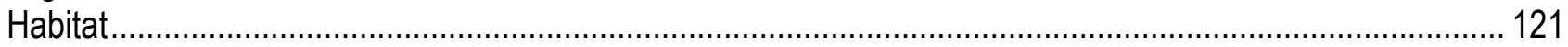

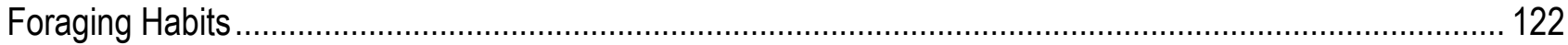

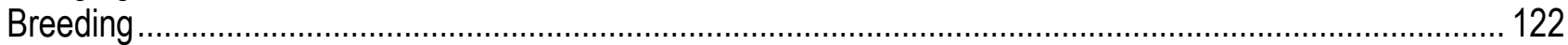

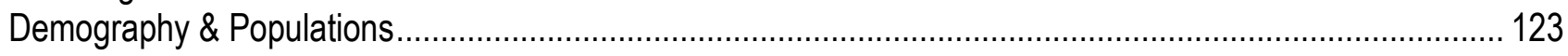




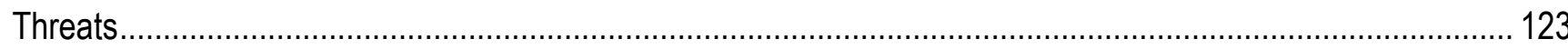

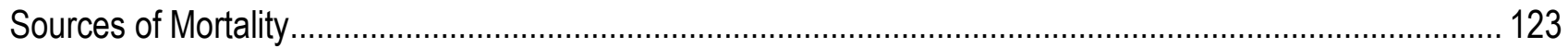

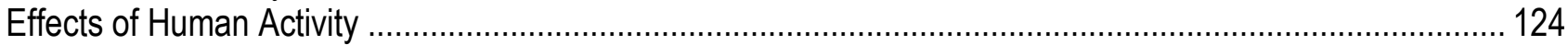

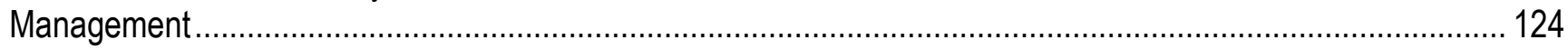

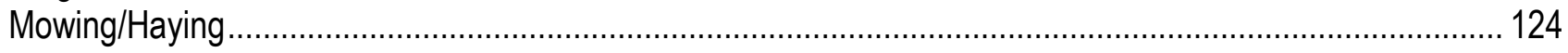

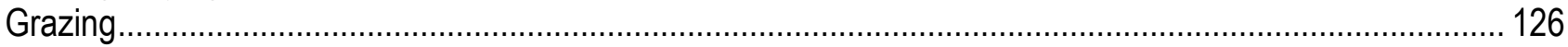

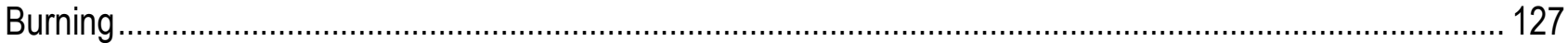

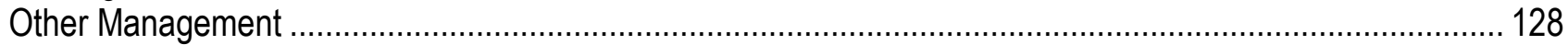

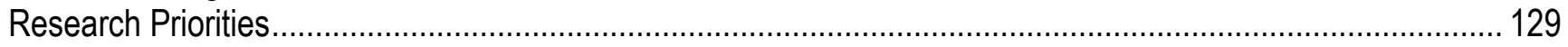

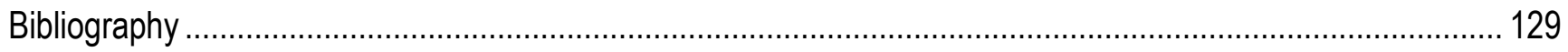

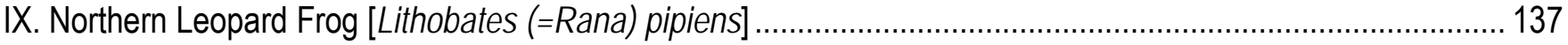

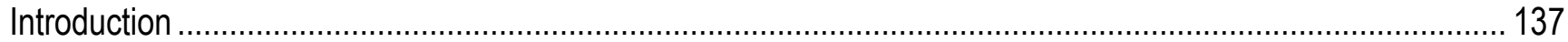

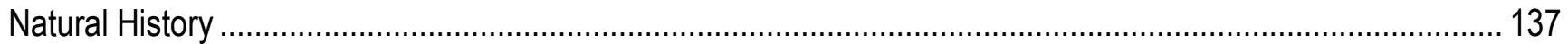

Morphological Characteristics .................................................................................................... 137

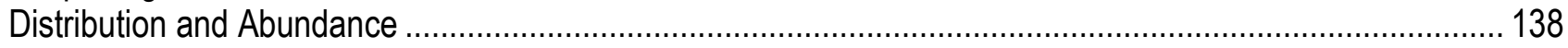

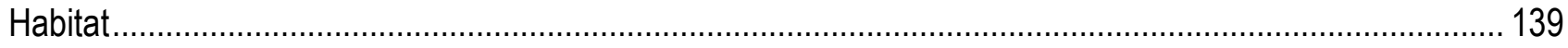

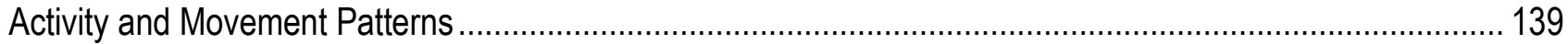

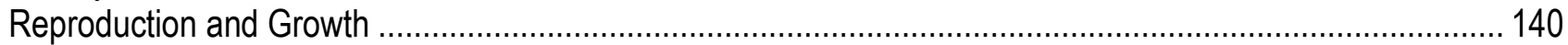

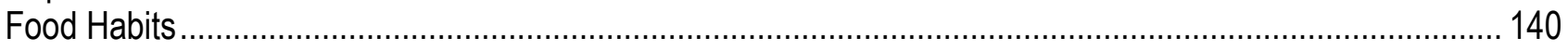

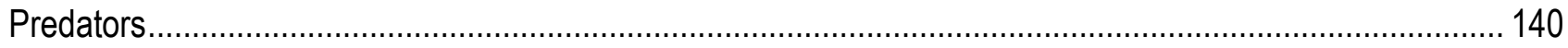

Threats

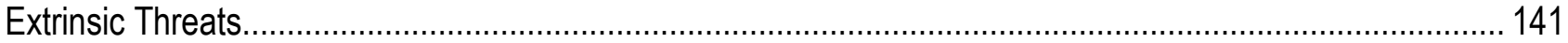

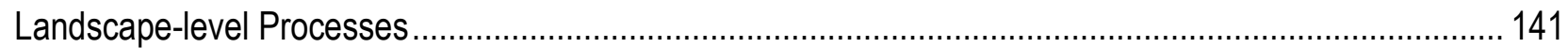

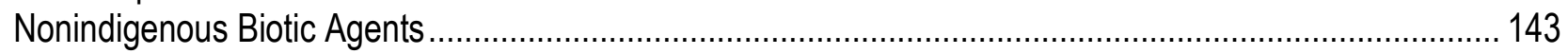

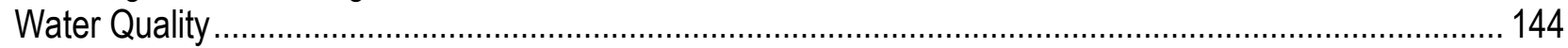

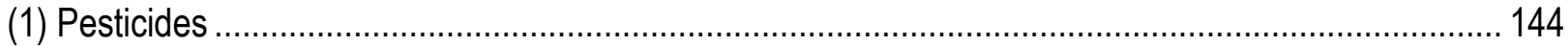

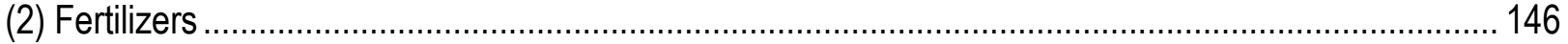

(3) Mining \& Heavy Metals ......................................................................................................... 146

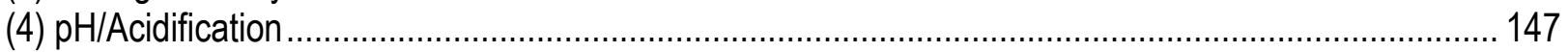

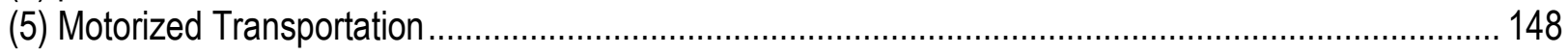

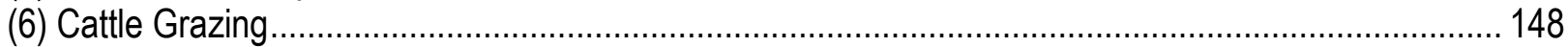

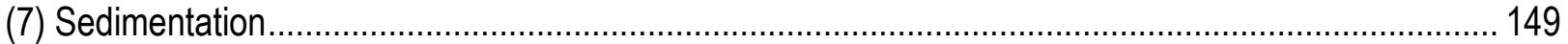

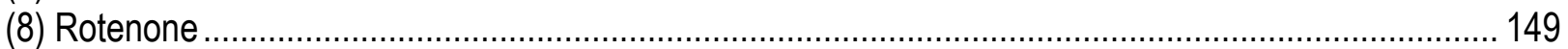

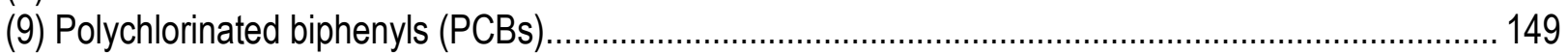

(10) Other Contamination and Limb Malformation .................................................................... 149

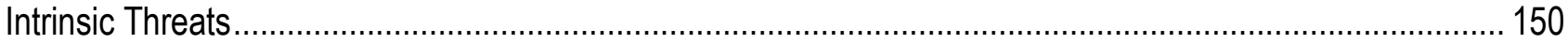

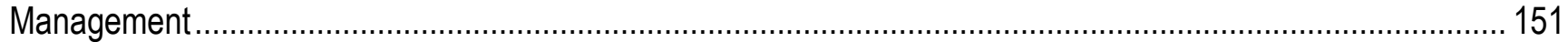

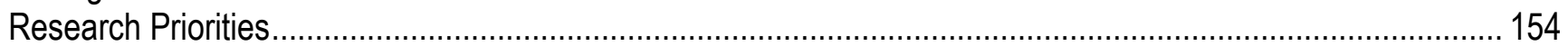

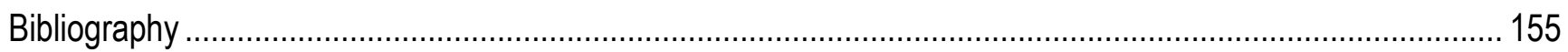

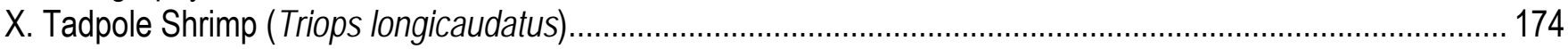

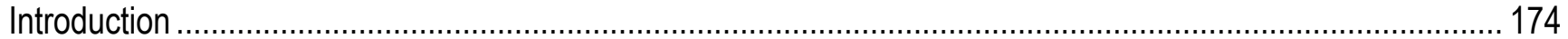

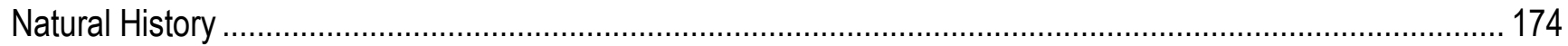

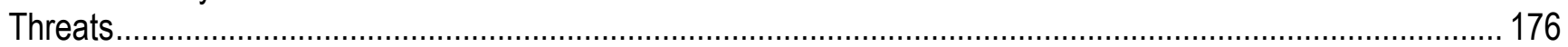

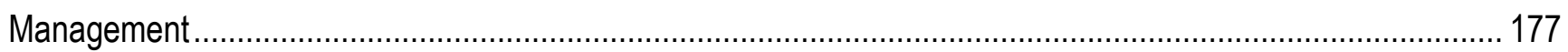

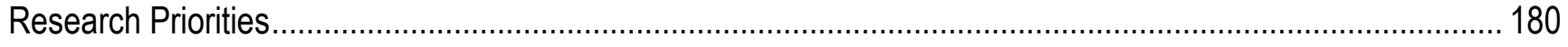

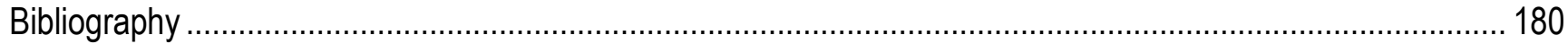

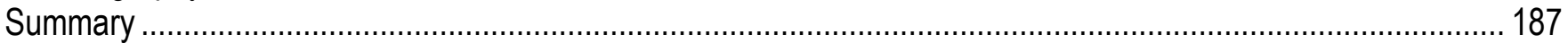




\title{
Species Accounts for the Alamosa/Monte Vista/Baca National Wildlife Refuge Complex
}

\author{
By Laura E. Ellison
}

\section{Executive Summary}

As part of an interagency agreement between the U.S. Geological Survey (USGS) and the U.S. Fish and Wildlife Service (USFWS), the Alamosa/Monte Vista/Baca National Wildlife Refuge Complex requested help with the synthesis of scientific information for 10 focal species and their habitat requirements in response to common Refuge management activities in the San Luis Valley, Colorado. This information will be instrumental in developing the Service's Comprehensive Conservation Plan (CCP), which is required by law for each unit of the National Wildlife Refuge System. After consultation with Refuge managers and USGS staff, the 10 species chosen for detailed literature reviews and synthesis of information were the following: (1) American Avocet (Recurvirostra americana); (2) Wilson's Phalarope (Phalaropus tricolor); (3) Sora (Porzana carolina); (4) Whitefaced Ibis (Plegadis chihi); (5) Black Tern (Chlidonias niger); (6) Short-eared Owl (Asio flammeus); (7) Brewer's Sparrow (Spizella breweri); (8) Savannah Sparrow (Passerculus sandwichensis); (9) Northern Leopard Frog [Lithobates (=Rana) pipiens]; and, (10) Tadpole Shrimp (Triops longicaudatus).

\section{Literature Review Methods}

A detailed literature review was conducted for each of the focal species using Internet resources and databases. The keywords chosen for these searches included the species common and scientific names, alone and in combination with the terms management, grazing, haying, mowing, threats, fire and prescribed fire, burning, water and water management, and Colorado. Databases and search engines used included Google (http://www.google.com), Google Scholar (http://scholar.google.com), SciVerse Scopus (http://www.scopus.com), ISI Web of Knowledge (http://apps.isiknowledge.com), and the U.S. Geological Survey (USGS) Library’s Digital Desktop (http://library.usgs.gov). The literature cited sections of manuscripts obtained from keyword searches were cross-referenced to identify additional citations or "gray literature" that was missed by the Internet search engines.

Although Colorado was a keyword in the literature searches, information gathered to develop the different species accounts is based on research conducted throughout the United States. As a result, research conclusions based on coastal or plains studies may, or may not, be applicable to the high elevation, intermountain basin in which the Alamosa/Monte Vista/Baca complex is located, but do provide general context to each topical theme being discussed herein.

\section{Format of Report}

This report is divided into 10 sections, with each section pertaining to one of the focal species. Each section is formatted on the basis of the following themes: an introduction to the species, a natural history subsection with pertinent facts about its unique biology and habitat requirements, a subsection describing threats to the species, a subsection on management activities of concern to the species, and a 
bibliography. Not all bibliographic references are cited within the text of the document. The final Summary subsection provides a table of general habitat requirements for the 10 focal species.

\section{Acknowledgments}

I thank Megan K. Eberhardt-Frank [U.S. Geological Survey (USGS), Fort Collins Science Center (FORT)] for her invaluable help with the detailed literature reviews for each species. David Hamilton (USGS, FORT) and Murray Laubhan (U.S. Fish and Wildlife Service, Quivira National Wildlife Refuge) provided helpful peer review comments. Eleanor Briccetti, photographer, provided the photographs of American avocets, savannah sparrow, short-eared owl, white-faced ibis, and Wilson's phalarope. The USFWS provided photographs of the Brewer's sparrow and sora. The northern leopard frog photograph is by Laurie Averill-Murray, Pacific Southwest Region, USFWS. The tadpole shrimp photograph is from Wikipedia (http://en.wikipedia.org/wiki/File:Triops_longicaudatus.jpg). The photograph of the black tern is by Jessi Miller. Jennifer Shoemaker (USGS, Science Publishing Network) provided assistance with formatting the final report. 


\section{American Avocet (Recurvirostra americana)}

\section{Introduction}

The American Avocet

(Recurvirostra americana) is among the most abundant avian species inhabiting inland, saline wetlands in North America (Wells, 2003). The American Avocet, hereafter "avocet," specializes in using temporally unpredictable wetlands of the arid western United States and breeds in large numbers at the marshes of Great (Robinson, 1996; Robinson and others, 1997). In the arid west, wetland priorities and urban priorities compete directly for limited supplies of fresh water. The use of water to meet the needs of healthy wetlands is competing with other uses for water, including human population growth and increasing urbanization (Meyer and others, 2007). Some wetlands that were once important avocet breeding centers have declined in area by as much as 90 percent. Avocets have also been victims of the Kesterson effect - a set of embryo deformities associated with selenium contamination in irrigation drain water first noted at Kesterson National Wildlife Refuge, California (Presser, 1994). Avocets were extirpated from much of their eastern range in the 1900s, and their continued persistence in the western United States will depend on inland wetland conservation and restoration efforts. Avocets are protected from unregulated destruction under general wildlife laws such as the Federal Migratory Bird Treaty Act and various state codes (Robinson and others, 1997).

Research on avocets has primarily focused on behavior and population ecology (Robinson and others, 1997). Hamilton (1975) described and compared the behaviors of avocets and black-necked stilts (Himantopus mexicanus) in California. Gibson $(1971 ; 1978)$ recorded breeding-season time budgets from Oregon. The conspicuous antipredator behaviors of avocets were studied in depth by Sordahl (1980; 1981; 1982; 1984; 1986; 1988; 1990; 1994; 2004) in Utah. Winter behavior and habitat use was the focus of research conducted in South Carolina (Boettcher, 1994; Boettcher and others, 1994; 1995) and in California (Evans, 1988; Evans and Harris, 1994). Avocets and black-necked stilts also have been a primary focus of ecotoxicological studies on the effects of irrigation drainage water on breeding waterbirds (for example, studies by Ohlendorf, Skorupa). Robinson and Oring (Robinson, 1996; Robinson and Oring, 1996; 1997) conducted population studies of hundreds of marked individuals in California, Nevada, and Utah, providing data on migratory movements, natal and breeding dispersal, population regulation, and population spatial structure (Robinson and others, 1997).

A simple Google search on the Internet for "Recurvirostra americana" revealed 115,000 results and a Google Scholar search provided 1,820 results (accessed 11 July 2011). "American avocet” revealed 474,000 results through Google and 2,040 results through Google Scholar (accessed 11 July 2011). 


\section{Natural History}

\section{Morphology and Systematics}

Avocets are long-legged shorebirds approximately 43-47 cm (centimeters) long with a bill length of 8.2-9.5 cm and a wingspread up to $91 \mathrm{~cm}$. They weigh between 275 and $350 \mathrm{~g}$ (grams). Sexes have similar plumage, but differ in size; females are smaller and have a shorter and more strongly recurved bill than males (Robinson and others, 1997). The plumage and morphology of this species are distinctive among other North American shorebirds. They are distinguished by strikingly contrasted black-and-white upperparts, white underparts, either rusty or gray head and neck, long upturned bill, large size, and long, grayish blue legs. Plumage changes seasonally; head and neck are rusty in breeding plumage and light gray in basic (winter) plumage.

Avocets are members of the Recurvirostridae family, which comprises three genera: Recurvirostra (avocets), Cladorhynchus (banded stilt), and Himantopus (stilts). Chu (1995) reviewed the multiple phylogenetic data analyses for this clade; the clade is probably most closely related to plovers, lapwings, and oystercatchers. There is also some fossil evidence that Recurvirostridae and flamingoes (Phoenicopteridae) are related (Olson and Feduccia, 1980). A hybrid avocet and blacknecked stilt hatched in captivity and the morphological characteristics were intermediate between the two species (Principe, 1977).

\section{Distribution}

Avocets breed commonly throughout the West in the Great Basin and Great Plains south to California and Texas (Robinson and others, 1997). The northern extent of their breeding range is central Alberta, southern Alberta, southern Saskatchewan, southwestern Manitoba, and western Minnesota. They winter on the Pacific and Gulf coasts from southern California into Mexico.

\section{Migration}

Avocets are medium-distance continental migrants from southern Canada to Mexico. The patterns of migration are poorly known and variable among years (Robinson and others, 1997). In the western United States, migration has both a north-south component and an inland-coastal component. They are known to stop for prolonged periods of time at intermediate sites throughout the migratory period (Robinson and Oring, 1996). The greatest fall and spring migration concentrations are through southeastern Oregon, central California, San Francisco Bay, Lahontan Valley, Nevada, and the Great Salt Lake, Utah. In central United States, the migration pattern is more dispersed and opportunistic (Skagen and Knopf, 1993).

In the western Great Basin, avocets exhibited movement prior to fall migration, possibly due to advantages of flocking during molt, location of an abundant food source, or assessing future potential breeding or staging sites (Plissner and others, 2000). For 25 avocets known to have remained in the survey region from early June through late September, the average number of lakes used was 2.1. Of 161 banded and radio-tagged birds, the mean distance traveled between lakes within the region prior to migration was $145 \mathrm{~km}$. No difference was detected between sexes in number of movements, number of lakes visited, or persistence in the region. Contrary to fall migratory movements, avocets during the premigratory (both spring and fall) period tended to move in a northerly rather than southerly direction, possibly to areas of abundant food resources. Resightings of color-banded avocets on breeding grounds in California and Utah indicated that avocets used several migratory routes, migrating individuals spent as long as 48 days at stopover sites, and traveled relatively short (about 250-500 km) distances between 
wetland sites, and siblings may travel together (Robinson and Oring, 1996). Compared to adults, firstyear avocets were more likely to be at coastal sites rather than inland sites.

\section{Habitat}

The Colorado Breeding Bird Atlas reported 74 percent of their avocet sightings occurred in emergent wetland marshes and lakes (Winternitz, 1998). Little is known about the area requirements of avocets. However, in a study in Manitoba examining the effects of wetland size on the occurrence of bird species, Daub (1993) found that avocets occurred only on wetlands 6-19.3 ha in size. Daub (1993) sampled wetlands ranging from $<1$ to $19.3 \mathrm{ha}$, and concluded that the avocet is an area-dependent species.

Avocets use exposed, sparsely vegetated salt flats, sandbars, peninsulas, mudflats, or islands adjacent to shallow ( $<1 \mathrm{~m}$ deep) water, conditions that occur in wetlands, lakes, fallow and flooded fields, or impoundments (Mitchell, 1917; Bent, 1962; Vermeer, 1971; Maher, 1974; Kondla, 1977; Kondla and Pinel, 1978; Grover, 1979; Grover and Grover, 1981; Grover and Knopf, 1982; Sidle and Arnold, 1982; Weber and others, 1982; Hirsch and Fouchi, 1992; Gunderson and others, 1992; See and others, 1992; Faanes and Lingle, 1995; Robinson and others, 1997; Beaver, 1998). Breeding habitat can be found in tilled, alkali, ephemeral, temporary, seasonal, semipermanent, and permanent wetlands, and in impoundments, sewage lagoons, and evaporation ponds (Stewart and Kantrud, 1965; Weber, 1978; Faanes, 1982; Weber and others, 1982; Kantrud and Steward, 1984; Giroux, 1985; Colwell, 1986; Dole, 1986; Prescott and others, 1995; Baylor, 1996; Robinson and others, 1997). In North Dakota, density of avocets was greatest in tilled wetlands, followed by alkali, seasonal, and semipermanent wetlands (Kantrud and Stewart, 1984). In South Dakota, avocets most frequently occurred in ephemeral wetlands, followed by tilled wetlands and wetlands located in pastures (Weber, 1978; Weber and others, 1982). In Alberta, avocets were most abundant in large ( $>8 \mathrm{ha}$ ) saline wetlands, followed by medium-sized (1-8 ha) saline wetlands, large ( $>8 \mathrm{ha}$ ) fresh wetlands, small ( $<1 \mathrm{ha})$ saline wetlands, medium-sized fresh wetlands, and small fresh wetlands (Prescott and others, 1995). Avocets may exhibit annual variation in nest site selection, moving to deeper, more permanent wetlands in dry years (Colwell, 1986; 1991). In Colorado, avocets preferred seasonal wetlands and habitats dominated by Baltic rush (Juncus balticus), sedges (Carex spp.), and grasses $<40 \mathrm{~cm}$ tall over semipermanent wetlands, habitats dominated by cattail (Typha spp.) and softstem bulrush (Scirpus validus) $>40 \mathrm{~cm}$ tall, saltgrass habitats, or upland shrub habitats (Laubhan and Gammonley, 2000).

Avocets generally nest on unvegetated ground or in areas with short, sparse vegetation that provide an unobstructed view from the nest (Sidle and Arnold, 1982; Giroux, 1985; Dole, 1986; Robinson and others, 1997; Conway and others, 2005b). Of 199 avocet pairs in Montana, 65 percent nested on bare ground, 13 percent nested in short ( $<12 \mathrm{~cm}$ tall) grasses, 15 percent nested in grasses of moderate height (13-37 cm tall), 7 percent nested in tall $(38-61 \mathrm{~cm})$ grasses, and no avocets nested in very tall $(>61 \mathrm{~cm})$ grasses (Dole, 1986). Nests are often slightly elevated $(2-15 \mathrm{~cm})$ above the surrounding substrate (Sidle and Arnold, 1982; Dole, 1986). In North Dakota and Montana, nests that were closest to the water's edge, on very wet sites, or in frequently flooded areas usually were elevated from the ground with vegetation (Sidle and Arnold, 1982; Dole, 1986).

Avocet nests are often placed near water and near clumps of vegetation or debris (for example, driftwood, fence posts) (Grover, 1979; Winton and Leslie, 1997). Distance of avocet nests to water range from 0 to $300 \mathrm{~m}$, although most nests are located within $60 \mathrm{~m}$ of water (Grover, 1979; Grover and Knopf, 1982; Sidle and Arnold, 1982; Giroux, 1985; Gunderson and others, 1992; Kuyt and Johns, 1992). Nests in Oklahoma were significantly closer to water than random points on a study area (Grover, 1979; Grover and Knopf, 1982). Of 23 nests in Oklahoma, 57 percent were located within 5 
cm of debris (Grover, 1979). In another Oklahoma study, 52 percent of 41 avocet nests were found within $5 \mathrm{~cm}$ of driftwood clumps or dead vegetation, 29 percent on human-made elevated habitat structures (for example, on plowed ridges and gravel mounds), 12 percent on open soil or sand, and 7 percent within $5 \mathrm{~cm}$ of live vegetation. Nests on open soil/sand experienced the lowest apparent nest success.

In the prairie regions of Alberta, Manitoba, Saskatchewan, and North Dakota, breeding densities of avocets were higher on islands than along wetland shorelines (Kondla and Pinel, 1978; Sidle and Arnold, 1982). Nest densities of avocets on islands in Montana, North Dakota, and South Dakota were significantly and positively related to percent bare ground and presence of saline wetlands (Lokemoen and Woodward, 1992). [However, the frequency of intraspecific brood parasitism is greater on islands and in the more northerly portions of the breeding range (Kondla and Pinel, 1978; Robinson and others, 1997) so drawing conclusions from nest "densities" as opposed to nest "success” can be misleading.] On constructed islands in wetlands of the Prairie Pothole Region of North Dakota, the density of avocet nests was higher on islands with beaches than than on islands without beaches (Dahl and others, 2003). In Alberta, the density of nesting avocets on islands in wetlands created to enhance waterfowl production was positively related to percentage of the island surface covered by sparse vegetation and with maximum water depth between the island and the nearest shoreline (Giroux, 1985). Newly constructed islands were preferred over older, more vegetated islands. Amount of sparse vegetation was inversely related to years since island construction. In Colorado, a series of newly constructed shallow wetlands and resting spots created for waterfowl contained nonvegetated areas suitable for nesting avocets (Beaver, 1998).

\section{Foraging Habits}

Avocets forage at various water depths, depending on age and bill length (Dole, 1986). Young (0-3 week-old) chicks forage at water depths of 0-90 mm (millimeters), but mainly at about $8 \mathrm{~mm}$. Older (3-6 week-old) chicks forage at depths from 0 to $100 \mathrm{~mm}$, but mostly at about $53 \mathrm{~mm}$. Adult females forage at water depths $>80 \mathrm{~mm}$, and adult males forage at depths of about $100 \mathrm{~mm}$. Osmundson (1990) also reported that adult avocets forage at depths ranging from 90 to $160 \mathrm{~mm}$. Avocets partition food resources depending on water depth and method of prey capture. Food is obtained by scythe-like movements in shallow water or in pools of water standing on the mud or by pecking (Burger and Gochfeld, 1986). Foraging avocets use habitats with fine sediments (Quammen, 1982; Danufsky and Colwell, 2003). The main foods taken by avocets are aquatic invertebrates in the water column and in sediment. They also eat terrestrial invertebrates, small fish, and seeds (Robinson and others, 1997). Ceratopogonidae (biting midges) and Chironomidae (nonbiting midges) were the dominant families of invertebrates eaten by avocets in migratory stopover sites in the Southern Great Plains (Andrei and others, 2009). Chironomid larvae were the major dietary component (44-77 percent) for migrating avocets on the Texas high plains (Baldassare and Fischer, 1984). Avocets also preferred intermediate and larger prey than conspecific foragers such as least and western sandpipers (Davis and Smith, 2001). In hypersaline foraging conditions, through a combination of behavioral and anatomical adaptations, avocets are able to rid their prey of most of the adherent lake water and thereby largely avoid problems of salt-loading and the ingestion of harmful ions (Mahoney and Jehl, 1985).

\section{Breeding}

Avocets arrive on the breeding grounds from early April to mid-May and depart from midAugust to mid-October (Bent, 1962; Salt and Salt, 1976; Knapton, 1979; Johnsgard, 1980; Sidle and Arnold, 1982; Hill, 1985; Dole, 1986; Janssen, 1987; Colwell and others, 1988; See and others, 1992; 
Robinson and others, 1997; Svingen, 1998). In Montana, peak egg-laying occurred in May (Dole, 1986). The species is single-brooded but commonly will renest following failure of the initial nest (Gibson, 1971; Sordahl, 1984; Dole, 1986; Robinson and others, 1997). Colorado Breeding Bird Atlasers found the earliest nest in April in Colorado, but the remainder were found from mid-May to 30 June. Precocial young were observed only from mid-June to mid-July. Atlas workers also found most nests and young in marshes (42 percent), around lakeshores (30 percent), and in salt meadows (8 percent). In 1875, the first avocet nest discovered in Colorado was found by Henshaw of the Wheeler Survey in Costilla County in the San Luis Valley (SLV) (Winternitz, 1998). Large numbers of avocets nest around the Great Salt Lake in Utah and a gap in their distribution used to exist between there and breeding avocets in the Colorado mountain parks. Since 1986, however, avocets have extended their breeding range to the western slope of Colorado. The Colorado Breeding Bird Atlas map showed substantial breeding in northeastern Colorado, both along the South Platte corridor and the edge of the Front Range from Denver north. A cluster of avocets in east-central Colorado consisted of birds scattered at reservoirs and at permanent and ephemeral ponds from the Arkansas River north to the Smoky Hill River in Cheyenne County. The SLV and North Park had concentrations of breeding avocets, but Atlasers also found more in South Park than expected and a surprising cluster in four blocks surveyed east of Interstate 25 in Huerfano and Las Animas Counties. The Atlas map suggested a gradual expansion of breeding populations of avocets in Colorado (Winternitz, 1998).

Avocets are semicolonial nesters (Robinson and others, 1997). Nesting most often occurs in loose colonies, although solitary nests also occur (Gibson, 1971; Grover, 1979; Grover and Knopf, 1982; Sidle and Arnold, 1982; Giroux, 1985; Dole, 1986; Robinson and others, 1997). Avocets also may nest in association with other species. In Oklahoma, avocets nested near snowy plovers (Chardrius alexandrines) and least terns (Sterna antillarum) (Hill, 1985; Winton and Leslie, 1997). Of 41 avocet nests, 64 percent nested $<180 \mathrm{~m}$ and 37 percent nested $\geq 180 \mathrm{~m}$ from another active plover, tern, or avocet nest (Hill, 1985). Mortality rate was lowest for nests in which the nearest nest belonged to a least tern, suggesting that avocets benefitted from nest defense behaviors of least terns. Mortality rates of nests of colonial and solitary avocets, however, were not significantly different. In North Dakota and Montana, mean distance between nests varied according to habitat (Sidle and Arnold, 1982; Dole, 1986). Mean distance between nests on islands or isolated sandbars ranged from 0 to $19 \mathrm{~m}$, whereas mean distance between nests on open salt flats, peninsulas, or shorelines ranged from 10 to $141 \mathrm{~m}$ (Vermeer, 1971; Grover, 1979; Grover and Knopf, 1982; Sidle and Arnold, 1982, Giroux, 1985; Dole, 1986). In North Dakota, islands occupied by American white pelicans (Pelecanus erythrorhynchos), double-crested cormorants (Phalacrocorax auritus), and gulls (Larus spp.) were avoided by nesting avocets (Sidle and Arnold, 1982).

Intraspecific brood parasitism commonly occurs within avocet colonies (Bent, 1962; Vermeer, 1971; Kondla, 1977; Kondla and Pinel, 1978; Giroux, 1985; Koonz, 1985; Dole, 1986; Kuyt and Johns, 1992; Robinson and others, 1997). The normal clutch size for avocets is four eggs, but when two or more females lay eggs in the same nest, superclutches of $\geq 6$ eggs can occur (Gibson, 1971; Koonz, 1985). The frequency of intraspecific brood parasitism is greater on islands and in more northerly portions of the breeding range (Kondla and Pinel, 1978; Robinson and others, 1997). Reported frequencies of intraspecific brood parasitism ranged from 8 percent of 13 nests to 50 percent of 30 nests (Vermeer, 1971; Kondla and Pinel, 1978; Giroux, 1985; Koonz, 1985). Dole (1986) found that nest success was greater for four-egg clutches than clutches with either less than or greater than 4 eggs. Dole suggested that clutches of $<4$ eggs do not stimulate adult avocets to incubate, whereas it may be physically difficult for avocets to effectively incubate clutches with $>4$ eggs. 
Preference for islands by breeding avocets may be due to greater protection from nest predators (Sidle and Arnold, 1982; Giroux, 1985). Robinson and others (1997) suggested that breeding densities of avocets were most influenced by the availability of nest sites, especially on islands, rather than overall wetland area. In Montana, hatching success was associated with island size and the distance of the island from shore (Dole, 1986). In contrast to findings in North Dakota, hatching success in Montana was lower on islands than along shorelines, mudflats, or a dry lake bed. Mammalian predators may have been able to swim or wade to islands that were near shore. Small islands with high nest densities were at risk of greater depredation because of the ease with which predators located nests (actual island sizes and distance of islands to shore were not given in the publication).

Although intraspecific brood parasitism is considered common, interspecific brood parasitism rarely occurs. An incident of interspecific brood parasitism by avocets was noted by Kuyt and Johns (1992) on breeding grounds in the Northwest Territories. Avocet eggs were found in two Mew gull (Larus canus) nests that were located near a small group of avocet nests. No known records of brood parasitism by brown-headed cowbirds (Molothrus ater) exist. Avocets are not suitable hosts for cowbirds because avocet young are precocial, whereas cowbird young are altricial.

Adult avocets occasionally return to the same breeding sites in subsequent years and may retain their mates of the previous year or years (Gibson, 1971; Sordahl, 1984; Colwell and Oring, 1988b; Robinson and Oring, 1997; Robinson and others, 1997). In California and Nevada, 116 of 478 adults (24 percent) bred one to two years after banding within $20 \mathrm{~km}$ of the banding site, 140 (29.3 percent) were seen in subsequent years as nonbreeders or as migrants, and 222 (46.4 percent) were never seen again (Robinson and Oring, 1997). No evidence of sex difference in philopatry was detected. Of 25 females and 35 males, 13 (52 percent) and 14 (40 percent), respectively, retained their mates from previous years (Robinson and Oring, 1997). In Oregon, one pair was observed with young the first year after banding, was absent the second year after banding, but was seen together again the third year after banding (Gibson, 1971). One pair remained paired for at least 3 years. In Utah, six of 21 (29 percent) adults returned to the study area the first year after banding (Sordahl, 1984). One pair was seen in two consecutive years, and one adult male was seen during three years. In Saskatchewan, two of two males and one of two females returned to the study area one year after marking (Colwell and Oring, 1988b).

After-hatch-year avocets occasionally return to breed at natal sites. In California, of 811 nestling avocets banded at one site, 34 (4.2 percent) returned when they were one or two years old (Robinson and Oring, 1997). Most avocets do not breed until they are two years old; of the 811 nestlings, 13 (1.6 percent) returned as breeding adults (Robinson and Oring, 1997). One example of long-distance dispersal was documented: a male banded as a chick was captured on a nest $480 \mathrm{~km}$ from the banding location. In Saskatchewan, of 13 marked chicks, none returned to the breeding site (Colwell and Oring, 1988b). In Utah, of 49 banded young, none returned in subsequent years (Sordahl, 1984).

\section{Demography and Populations}

An adult avocet banded in 1977 was later recovered in 1985, so the bird was at least 9 years old (Robinson and others, 1997). There are no data available on annual survival of avocets. Population status of breeders is not known (Robinson and others, 1997). At least 100,000 individuals winter in North America west of the Rocky Mountains (Page and Gill, 1994). These numbers are probably reduced compared to those of presettlement conditions because of wetland losses during the last 200 years (Page and Gill, 1994). Peak numbers of migrants are approximately 14,000 in southeastern Oregon, 10,000 in the Central Valley, California (Shuford and others, 1994a); 100,000 at the Salton Sea, California (Setmire and others, 1993), 24,000 in the Lahontan Valley, Nevada, and 252,000 at the Great Salt Lake, Utah (Shuford and others, 1994b). 
Breeding Bird Survey (BBS) data showed no significant trends for the period 1966-1994 in the conterminous United States, its regions, or the entire survey area (Sauer and others, 1996). During 19651979, statistically significant trends in avocet numbers were detected, with increases in the central region, in the conterminous United States, and continentwide (Robbins and others, 1986). There were no significant trends for these regions, however, during 1980-1994 (Sauer and others, 1996). The BBS regional trend analysis for avocets along 30 Colorado BBS routes from 1966 to 1999 showed a negative trend estimate of -4.8 (-9.8, 0.2; 95 percent CI) (Sauer and others, 2011). From 1999 to 2009, the trend was also negative and estimated to be -5.0 (-12.4, 2.2; 95 percent CI). However, the regional credibility measure for this species for Colorado was category "yellow," meaning that data were deficient because of overall low abundances of avocets per route and/or the results were too imprecise to detect long-term trends.

\section{Threats}

\section{Sources of Mortality}

Avocets and black-necked stilts are the shorebird species most frequently stricken with botulism, a disease caused by the bacterium Clostridium botulinum type C (Rosen, 1971; Adams and others, 2003). The diets, ranges, and habitat preferences of avocets all correspond to risk factors for occurrence of avian botulism epidemics. Large numbers of individuals are most likely to be affected in the western United States, especially California, Utah, and Nevada, in late summer and early fall, and in years when higher-than-normal precipitation produces abundance of shallow, stagnant wetlands (Robinson and others, 1997). The botulism toxin causes flaccid paralysis, eliminating the ability to use legs (Rosen, 1971), and in avocets, causes twisting of the neck (Alcorn, 1942).

Major predators of adult avocets are peregrine falcons (Falco peregrinus; Evans, 1988; Porter and White, 1973), prairie falcon (F. mexicanus; Porter and White, 1973), great-horned owl (Bubo virginianus; Robinson and others, 1997), northern harrier (Circus cyaneus; Evans, 1988), and red fox (Vulpes vulpes; Robinson and others, 1997). On young avocets, predators include peregrine falcon, northern harrier, and mink (Mustela vison; Robinson and others, 1997). Egg predators include California (Larus californicus) and ring-billed (L. delawarensis) gulls, common raven (Corvus corax), badger (Taxidea taxus), striped skunk (Mephitis mephitis), long-tailed weasel (Mustela frenata), coyote (Canis latrans), raccoon (Procyon lotor), red fox, and gopher snake (Pituophis melanoleucus) (Gibson, 1971; Grover and Knopf, 1982; Sidle and Arnold, 1982; Alberico, 1993; Robinson and others, 1997).

In addition to disease and predation, mortality of flightless young was observed following unseasonably cold storms, and chick mortality due to the effects of contaminants was observed (Robinson and others, 1997 - see next section for more information on contaminants). Shooting and trapping led to population declines, particularly on the Atlantic Coast, before the 1900s (Robinson and others, 1997). Avocets were formerly an important game bird in California, and large numbers were sold in markets in Stockton and San Francisco (Grinnell and others, 1918). Avocets are now protected under the Migratory Bird Treaty Act of 1918 and illegal shooting and trapping is now probably a minor source of mortality.

\section{Pesticides and Other Contaminants}

Eight years after DDT was banned in the United States, DDE was still accumulating in wintering avocets along the south Texas coast (Robinson and others, 1997). The levels of these organic compounds detected in birds increased by 40 percent from October to December, then remained stable until February (White and others, 1983). Elevated, but most likely nontoxic, levels of the residues of 
DDT metabolites (particularly DDE) in eggs were detected in California, Idaho, Oregon, Montana, and Wyoming from 1986-1991 (Knapton and others, 1988; Lambing and others, 1988; Peterson and others, 1988; Schroeder and others, 1988; Rinella and Schuler, 1992; Rinella and others, 1994; Henny and others, 2008). The maximum recorded DDE concentration of 5.7 ppm (parts per million; wet weight) was found in an egg from Montana (1986-1987). The presumptive adverse effects threshold for DDE is from 3-8 ppm (wet weight).

Many wetlands used by avocets in the western United States have been contaminated as a result of irrigation and other human activities (U.S. Fish and Wildlife Service, 1992). The first indication that irrigation practices were contaminating wetlands on a dramatic scale was at Kesterson National Wildlife Refuge, San Joaquin Valley, California (Ohlendorf and others, 1986b; 1989; 1990). Irrigation drainage water was diverted to the Refuge for disposal and the project was initially viewed as a habitat replacement success. Like other waterbirds, however, avocets breeding at Kesterson failed to reproduce successfully (Williams and others, 1989) because drain water supplying the wetland was contaminated with selenium concentrated through soil-leaching and water-recycling (Ohlendorf and others, 1986a). Bioaccumulation of these toxicants resulted in low hatchability of eggs, dramatic developmental defects in embryos that survived to later stages of development (teratogenesis; Hoffman and others, 1988), and subsequent death of chicks that did not hatch (Ohlendorf and others, 1986b; 1989; 1990; Williams and others, 1989). Selenium also impairs growth and immune function of avocet chicks (Fairbrother and others, 1994). Kesterson has since been filled with uncontaminated soil in order to displace breeding birds to wetlands of better habitat quality, and habitat managers are monitoring potential bioaccumulation through the new terrestrial food chain (Wu and others, 1995). Selenium pollution has since been documented to be a widespread problem associated with irrigated agriculture in the western United States (Seiler and Skorupa, 1995). Normally, sets of eggs average $<3$ ppm selenium (dry weight), but at contaminated sites, they can average up to 86 ppm (Skorupa and Ohlendorf, 1991; See and others, 1992).

Hoffman (2002) reviewed the role of selenium toxicity and oxidative stress in aquatic birds, including avocets. Below are a few examples of studies examining selenium and its adverse effects on avocets:

- In California, an exposure-response relationship existed between egg selenium concentration and incidence of embryo deformity (Robinson and others, 1997; Skorupa, 1998). Eggs with selenium concentrations $\geq 40$ ppm dry weight had 0 percent incidence (based on 486 eggs) of deformed embryos; eggs with 41-60 ppm selenium had 5 percent (based on 26 eggs) deformity, eggs with 61-80 ppm selenium had 8.3 percent (based on 14 eggs) deformity, and eggs with $81-110$ ppm had 25 percent (based on 15 eggs) deformity. Percentages were calculated by weighting results for each 5-ppm interval equally. Skorupa (1998) conducted a logistic regression analysis of the embryonic response for avocet eggs exposed to selenium and reported effect concentrations of 41 , 74, and 105 ppm selenium dry weight for 1 percent, 10 percent, and 50 percent rates of embryo deformities, respectively (for example, in toxicological nomenclature the EC50 $=105 \mathrm{ppm})$. These effect concentrations indicated that avocets were significantly less vulnerable to selenium poisoning than were black-necked stilts (Himantopus mexicanus), a closely related and ecologically similar species of shorebird.

- Selenium-contaminated evaporation ponds in Tulare Basin, California, are used by avocets migrating from uncontaminated sites in the western United States (Robinson and Oring, 1996). Some birds occupy these ponds for as long as 48 days, long enough for significant amounts of selenium to accumulate in their bodies (Heinz and others, 1990; 
Robinson and Oring, 1996). A potential for significant population-level impacts exists at the selenium-contaminated Salton Sea, California, where an estimated 100,000 avocets winter (Setmire and others, 1993).

- In Wyoming, selenium levels of 38 to 54 ppb (parts per billion) in lakes were associated with high selenium levels in eggs ( $>8 \mathrm{ppm})$ and livers $(>30 \mathrm{ppm})$ of adult avocets (both live and dead birds) (Skorupa, 1998; See and others, 1992). Of 102 avocet eggs, selenium concentrations ranged from 24.2 to 135 ppm dry weight and averaged 82.7 ppm dry weight. Mean egg concentrations of >13-24 ppm dry weight were associated with embryo deformities. No malformed embryos were found in the first year of the study, but in the second year 24 percent of 37 embryos had malformations. Crossed bills and malformed legs and feet were the most common types of deformities. Mean concentrations of $>8$ ppm dry weight were associated with impaired egg hatchability. Cause of selenium embryotoxicity was irrigation over soils derived from Cody shale, which tend to have a high selenium content. Selenium discharge from sub-basins was related to irrigation intensity (measured by the area of irrigated land) and the concentrations of selenium in groundwater.

- At Freezout Lake Wildlife Management Area and Benton Lake National Wildlife Refuge in westcentral Montana, elevated levels of selenium were found in avocet embryos and livers (Nimick and others, 1996). Water sources for both lakes were irrigation return flow, surface runoff, and direct precipitation. At Freezout Lake, based on 73 embryos collected one year and 17 embryos collected the following year, geometric mean selenium concentrations ranged from 6 to 17 ppm. Livers from 16 avocets contained selenium concentrations that ranged from 13 to $43 \mathrm{ppm}$ and averaged $22 \mathrm{ppm}$. At Benton Lake, based on 36 embryos collected one year and 10 embryos collected the following year, geometric mean selenium concentrations ranged from 3.4 to $3.7 \mathrm{ppm}$. Livers from 28 avocets contained selenium concentrations that ranged from 9.3 to $45 \mathrm{ppm}$ and averaged $20 \mathrm{ppm}$.

\section{Loss and Degradation of Wetlands}

Wetland losses and conversion in North America (Dahl, 1990) have led to population declines of avocets (for example, Bent, 1927; 1962; Page and Gill, 1994). Many traditional breeding areas depend on vernal flooding, which is now rare because of agricultural diversion of in-stream flows and urban flood control projects (Robinson and others, 1997). Rangewide loss of historical perennial wetlands and coastal intertidal wetlands also has been severe (Helmers, 1992). Use of salt ponds, sewage ponds, agricultural evaporation ponds, and wet agricultural areas such as rice fields and flood-irrigated fields may counterbalance some historical wetland losses. These surrogate habitats, however, are not as likely as natural habitats to include predator-safe islands for nesting (Robinson and others, 1997). Avocets are also threatened by widespread agricultural and industrial degradation of water quality. Major breeding, staging, and wintering areas in the Pacific Flyway, such as the San Francisco estuary, the San Joaquin Valley, and the Salton Sea are already seriously polluted (Moore and others, 1990; Harvey and others, 1992).

Increased salinization of water from agricultural drain water, surface flow, and subsurface flow is a problem in at least some inland wetlands in every western state in the United States (U.S. Fish and Wildlife Service, 1992). Because of the multitude of ecosystem-level changes that salinization produces, salinization is likely to have significant impacts on populations of temperate-breeding shorebirds, 
including avocets (Rubega and Robinson, 1997; Hill, 1989). At highly salinized wetlands, avocet chick survival is likely reduced (Hannam and others, 2003; Robinson and others, 1997).

The ability of avocets to colonize newly available habitats provides some protection from the effects of locally changing patterns of habitat availability, but it will not help the species cope with the effects of permanent habitat loss. Avocets show fidelity to their breeding areas and they show little tendency to disperse in response to nest failure. Because avocets use ephemeral wetlands and wet playas extensively, they are likely to be affected by changing precipitation patterns associated with climate change.

\section{Disturbance}

At agricultural evaporation ponds, sewage ponds, and probably commercial salt ponds, routine grading of levees destroys many avocet eggs (Robinson and others, 1997). At one evaporation pond, 160 of 769 eggs were lost in one season (21 percent) (Robinson and others, 1997). At another evaporation pond, 100 chicks died because they were trapped inside discarded motor vehicle tires placed at shorelines to stabilize earthen levees against erosion (Robinson and others, 1997). Wintering flocks of avocets are easily disturbed, taking flight in response to cars, trucks, motorcycles, mopeds, airplanes, airboats, motorboats, shooting, human activity, and dogs. At Humboldt Bay, California, levels of human disturbance were probably not as detrimental to avocets relative to natural disturbances by raptors (Evans, 1988).

Research activities have been shown to negatively affect avocets. Nests visited early, when only one egg is present, have moderately high probability of being abandoned (Robinson and others, 1997). In Lassen County, California, 36 percent of 201 nests found with one egg were abandoned, while 9.5 percent of 1,056 nests found with $>1$ egg were abandoned (Robinson and others, 1997). Abandonment rates were similar for nests in Tulare Basin, California (35 percent if found with one egg, 0 percent otherwise). Nest-trapping and banding can also influence movement behaviors of individuals. For example, 16 percent (4 of 25) of incubating birds disappeared from a study area immediately after being captured and were resighted at migration sites (some within as few as 3 days; Robinson and Oring, 1996). Nest-trapping and banding also affected dispersal distances in the year immediately after banding (Robinson and Oring, 1997).

\section{Management}

\section{Response to Management}

Little is known concerning the direct effects of burning, mowing, or grazing on avocets (Dechant and others, 2002). In North Dakota, avocets nested along a burned shoreline (Sidle and Arnold, 1982). However, nests on this shoreline had lower hatching success (number of eggs hatched per nest) than nests on an island, a sandbar, and four peninsulas. In this location, preference for islands by breeding avocets may have been due to greater protection from nest predators (Sidle and Arnold, 1982; Giroux, 1985). Because avocets prefer islands for nesting, prescribed burning on islands during the breeding season is usually not recommended because fire eliminates all suitable nesting cover such as tall weeds, grasses, or low shrubs (Lokemoen, 1993).

Gradual drawdowns of water levels in wetlands, mowing, burning, and shallow disking have been suggested to be beneficial to migrating shorebirds, including avocets. Davis and Smith (1998) studied the ecology and management of migrant shorebirds in the Playa Lakes Region of Texas. They suggested that for migrant shorebirds, the focus should be on creating and maintaining habitats characterized by sparse vegetation cover, and an adequate area of mudflat (at least 10-15 percent) and 
shallow water (at least 10-20 percent). Because invertebrates are important foods for migrant shorebirds, management should focus on enhancing invertebrate populations in playas (Eldridge, 1992). Gradual drawdowns of playas with deep water and flooding of dry playas were suggested to provide available habitat for shorebirds throughout the migration period. If vegetation cover in playas is dense $(>50$ percent), mowing, shallow disking (for example, partially bury plant biomass), or controlled burning could be used to reduce vegetation cover and provide a detrital food base to enhance invertebrate populations (Davis and Smith, 1998). Aquatic invertebrates increase when wetlands are fertilized by mowing and grazing, but water control impoundments are easier management tools (Eldridge, 1992). The proper regime of drawdown and flooding can stimulate plant growth and decomposition and create a detrital food source for invertebrates. When water is drawn down slowly (2 to $4 \mathrm{~cm}$ per week) during the appropriate times of the year, migrating shorebirds are attracted to the available invertebrates. Complete drawdowns during migration, however, especially of semi-permanent wetlands, are discouraged because invertebrates are reduced or eliminated (Swanson and Meyer, 1977).

Agricultural drainage can be successfully used to provide highly productive managed wetlands for avocets (and black-necked stilts)(Davis and others, 2008). In the Tulare Lake Drainage District, California, operators of selenium-contaminated evaporation ponds are required via Waste Discharge Permits to provide mitigation habitat targeted for breeding recurvirostrids (California State Water Resources Control Board, 1995). In a 10-year study of this area, a 117-ha (hectare) wetland was designed, constructed, and operated to provide foraging and nesting habitat for avocets (Davis and others, 2008). The design for this constructed wetland incorporated a 2:1 ratio of foraging habitat to nesting habitat and water depths of 10-15 cm. The constructed wetland included low-profile lanes (shoreline) immediately adjacent to extensive shallow-water areas to support macroinvertebrate production and provide extensive foraging habitat. There were 34 lanes, each approximately $1.6 \mathrm{~km}$ long, providing more than $59 \mathrm{~km}$ (kilometers) of nesting habitat approximately $10 \mathrm{~m}$ wide and wetted foraging areas approximately $20 \mathrm{~m}$ wide, with shoreline slope of 10-12:1 (horizontal: vertical). Water supply for the wetland was from low-selenium saline agricultural drainage water, or a blend of freshwater and saline supplies. Selenium concentrations and electrical conductivity were monitored. Invertebrate breeding ponds were created throughout the interior of the wetland habitat. The wetland was encircled by an electrified perimeter fence to inhibit large mammalian predators (for example, coyotes). Coincident with the wetland construction, 2 evaporation basins totaling 1,174 ha were physically modified, and hazing was implemented to discourage use by shorebirds. In the first year of wetland operation (1995), avocet and black-necked stilt nest construction density was 17.6 nests/ha. Before the mitigated wetland went into operation (1994), there was a combined density of only 1.9 nests/ha at the evaporation basins. From 1995 to 2004, nesting attempts by avocets and stilts at the wetland averaged 2,896 per year (24.8 nests/ha). Nest success at the constructed wetland averaged 82 percent for avocets and nest predation was estimated to be $<1$ percent, whereas predation at the evaporation ponds exceeded 30 percent.

\section{Recommendations}

Fluctuations in water levels can place avocet nests at risk during the breeding season (Plissner and others, 2000); careful consideration of human-caused changes in water levels, or construction of nest ridges to elevate nests, may be necessary to prevent or at least minimize nest losses. For breeding avocets, elevated nest structures, such as ridges, and exclosures made of electrical fencing may increase nesting success of avocets by reducing loss of nests due to flooding and nest predation, respectively (Koenen, 1995; Winton and Leslie, 1997). Nest losses due to flooding and predation may be considerable. Of 193 avocet nests in California, 84 (44 percent) were lost to predation and 11 (6 
percent) to changes in water level (Ohlendorf and others, 1989). In Oklahoma, exclosures and nest ridges were used to reduce nest predation and flooding, respectively, on snowy plovers and least terns (Koenen, 1995). Although the effects of exclosures and ridges on avocet nest success were not examined, avocets did nest in proximity to the plovers and terns. Fluctuations in water levels may cause the destruction of nests because of the proximity (usually $<60 \mathrm{~m}$ ) with which avocets place their nests to water (Plissner and others, 2000). Nest ridges were $10 \mathrm{~m}$ long by $1 \mathrm{~m}$ wide by $0.5 \mathrm{~m}$ high and were spaced 20-30 m apart. Electric fences (1,000-6,000 volt) were used to form predator exclosures ranging in size from 3.75 to 24 ha. Five strands of wire were placed from 14 to $86 \mathrm{~cm}$ from the ground.

To reduce risk of avian contamination and toxicity due to drainage and irrigation water, either the amount of contaminants in drainage water should be reduced, or avian use of contaminated ponds should be reduced (Skorupa and Ohlendorf, 1991; Skorupa, 1998). To prevent avian toxicity but not avian contamination, drainage water should be purified to $<10 \mathrm{ppb}$ waterborne selenium. However, as these standards cannot be met with current technology, deterring avian use of contaminated drainage water may be the only option. Drainage water containing 3-20 ppb selenium should be considered potentially hazardous to waterbirds, whereas concentrations $>20 \mathrm{ppb}$ should be considered hazardous.

Power lines should not be constructed through or within $1 \mathrm{~km}$ of known historical high-water marks of wetlands, through dry basins known to hold water intermittently, or through heavily used waterbird migration routes (Malcolm, 1982). In cases where power lines must cross wetlands, an attempt should be made to hide the lines with structures such as bridges (McKenna, 1976). Power lines should be buried where possible and/or corridors established where power lines can be clumped to reduce their negative effects on shorebirds (McKenna, 1976).

The Central Plains/Playa Lakes Regional Shorebird Conservation Plan (Fellows and others, 2001) suggested that management for shorebirds should focus on enhancing invertebrate populations and maintaining sparse vegetative cover and adequate mudflat (at least 10-15 percent) and shallow water (at least 10-20 percent) habitats throughout the period used by the birds. Habitat can be managed through gradual drawdowns of playas with deep water and flooding of dry playas where water movement capabilities exist. Mowing and shallow discing can be used to create preferred habitat conditions and provide a detrital food base to enhance invertebrate populations. Variations of current moist-soil management practices used by waterfowl managers (Frederickson and Taylor, 1982; Haukos and Smith, 1993) may also benefit shorebirds, especially in the spring (Fellows and others, 2001).

The Nevada Conservation Strategy for the American avocet (http://www.gbbo.org/pdf/bcp/32_American\%20Avocet.pdf, Accessed 1 July 2011) provided the following habitat strategies:

- Promote seasonal fresh-water runoff into ephemeral wetlands and playas, as well as into sparsely-vegetated permanent marshes, sufficient to create mudflats and maintain a shallow-water shoreline for the longest possible period.

- Manage and restrict playa activities to protect the integrity of the clay soil pan and maximize water retention.

- Promote wetlands with uneven bottoms and shallow islands, which are especially important for nesting.

- Artifically mitigate wetlands to provide productive breeding habitat. Ideal configuration is $>130$ ha wetland with a 2:1 ratio of shallow water $(<15 \mathrm{~cm})$ feeding areas that transition to elevated nesting areas. 


\section{Research Priorities}

No species-specific research priorities for avocets were found during this literature search; however, the U.S. Shorebird Conservation Plan (Oring and others, 2000) provided the following priority research topics:

- Identification of population limiting factors such as those influencing breeding success, juvenile and adult mortality, and disturbances that affect breeding success and mortality;

- Understanding patterns of distribution and abundance, and the factors controlling them;

- $\quad$ Space use and dispersal, including movements within and among years;

- Increasing understanding of the dynamics of migration patterns, including how and why populations move among sites;

- Understanding the timing of landscape level habitat use, which is critical for monitoring studies, and understanding factors affecting turnover rates;

- Analysis of dietary requirements, elucidation of dietary preferences, nutritional requirements, and metabolic needs;

- Identifying geographic population subdivision, determining conservation issues below the species level, and identification of the role of subspecies in the overall population dynamics of the species;

- Modeling potential impacts of an development of protocols to mitigate effects of global climate change;

- Development of techniques to deter predators, for example, including aversive conditioning to reduce losses from both avian and mammalian predators;

- Disturbance effects on foraging and breeding, including measuring disturbance impact and/or studying ways of reducing disturbance;

- Techniques for increasing productivity, including captive breeding reintroduction and associated techniques;

- Development of models to predict population trends;

- Exploration of population fluctuations, and their impact on estimates of numbers using sites; and

- Evaluation of the validity of sampling techniques.

\section{Bibliography}

Ackerman, J.T., Takekawa, J.Y., Eagles-Smith, C.A., and Iverson, S.A., 2008, Mercury contamination and effects on survival of American avocet and black-necked stilt chicks in San Francisco Bay: Ecotoxicology, v. 17, p. 103-116.

Adams, S.G., Conly, F.M., Gratto-Trevor, C.L., Cash, K.J., and Bollinger, T., 2003, Shorebird use and mortality at a large Canadian prairie lake impacted by botulism: Waterbirds, v. 26, p. 13-25.

Ahern, W.B., and Schmidt, G.D., 1976, Parasitic helminthes of the American avocet Recurvirostra americana: four new species of the families Hymenolepididae and Acoleidae (Cestoda:

Cyclophyllidae): Parasitology, v. 73, p. 381-398.

Alberico, J.A.R., 1993, Drought and predation cause avocet and stilt breeding failure in Nevada: Western Birds, v. 24, p. 43-51.

Alcorn, J.R., 1942, Birds affected by botulism at Soda Lake, Nevada: Condor, v. 44, p. 80-81. Alcorn, J.R., 1988, Birds of Nevada: Fairview West Publications, Fallon, Nevada.

Altmann, J., 1974, Observational study of behavior: sampling methods: Behaviour, v. 49, p. 227-265. 
Andrei, A.E., Smith, L.M., Haukos, D.A., and Surles, J.G., 2006, Community composition and migration chronology of shorebirds using the saline lakes of the Southern Great Plains, USA: Journal of Field Ornithology, v. 77, p. 372-383.

Andrei, A.E., Smith, L.M., Haukos, D.A., Surles, J.G., and Johnson, W.P., 2009, Foraging ecology of migrant shorebirds in saline lakes of the southern Great Plains: Waterbirds, v. 32, p. 138-148.

Andrews, R., and Righter, R., 1992, Colorado birds: a reference to their distribution and habitat: Denver Museum of Natural History, Denver, Colorado.

Ashley, M.C., Robinson, J.A., Oring, L.W., and Vinyard, G.A., 2000, Dipteran standing stock biomass and effects on aquatic bird predation at a constructed wetland: Wetlands, v. 20, p. 84-90.

Austin, J.E., and Pyle, W.H., 2004, Nesting ecology of waterbirds at Grays Lake, Idaho: Western North American Naturalist, v. 64, p. 277-292.

Bailey, F.M., 1928, Birds of New Mexico: New Mexico Department of Game and Fish, Santa Fe, New Mexico.

Baldassarre, G.A., and Fischer, D.H., 1984, Food habits of fall migrant shorebirds on the Texas high plains: Journal of Field Ornithology, v. 55, p. 220-229.

Baumgartner, F.M., and Baumgartner, A.M., 1992, Oklahoma bird life: University of Oklahoma Press, Norman, Oklahoma.

Baylor, L.M., 1996, American avocets breeding in Harding County: South Dakota Bird Notes, v. 49, p. 9.

Beaver, D.L., 1998, Nesting records for black-necked stilt, American avocet, western grebe, and Clark’s grebe in Brown's Park National Wildlife Refuge, Moffat County, Colorado: Journal of Colorado Field Ornithology, v. 32, p. 61-63.

Bent, A.C., 1927, Life histories of North American shorebirds, Part 1: U.S. National Museum Bulletin, v. 142,

Bent, A.C., 1962, Life histories of North American shorebirds, Part 1: Dover Publications, Inc., New York, New York, 602 pp.

Bergeron, D., Jones, C., Genter, D.L., and Sullivan, D., 1992, P.D. Skaar’s Montana bird distribution, $4^{\text {th }}$ edition: Montana Natural Heritage Program, Helena, Montana.

Blick, D.J., Jr., 1980, Advantages of flocking in some wintering shorebirds: Unpublished PhD Dissertation, University of Michigan, Ann Arbor, Michigan.

Boettcher, R., 1994, Winter ecology of American avocets in coastal South Carolina: Unpublished M.S. Thesis, Clemson University, Clemson, South Carolina.

Boettcher, R., Haig, S.M., and Bridges, W.C., 1994, Behavioral patterns and nearest neighbor distances among nonbreeding American avocets: Condor, v. 96, p. 973-986.

Boettcher, R., Haig, S.M., and Bridges, W.C., 1995, Habitat-related factors affecting the distribution of nonbreeding American avocets in coastal South Carolina: Condor, v. 97, p. 68-81.

Blick, D.J., Jr., 1980, Advantages of flocking in some wintering shorebirds: Unpublished PhD Dissertation, University of Michigan, Ann Arbor, Michigan.

Brown, R.G., and Engleman, L., 1988, First record of American avocet from the Republic of Panama: American Birds, v. 42, p. 28.

Brush, T., 1995, Habitat use by wintering shorebirds along the lower Laguna Madre of south Texas: Texas Journal of Science, v. 47, p. 179-190.

Burger, J., and Gochfeld, M., 1986, Age differences in foraging efficiency of American avocets, Recurvirostra americana: Bird Behavior, v. 6, p. 66-71.

California State Water Resources Control Board, 1995, Acceptance of settlement agreements and revision of waste discharge requirements for six operators of agricultural subsurface drainage 
evaporation ponds in the Tulare Basin: Resolution No. 95-46, California State Water Resources Control Board, Sacramento, California.

Clapp, R.B., Klimkiewicz, M.K., and Kennard, J.H., 1982, Longevity records of North American birds: Gaviidae through Alcidae: Journal of Field Ornithology, v. 53, p. 81-124.

Colwell, M.A., 1986, Intraspecific brood parasitism in three species of prairie-breeding shorebirds: Wilson Bulletin, v. 98, p. 473-475.

Colwell, M.A., 1991, Effects of fluctuating wetland conditions on prairie shorebirds: Pp. 173-180 in Holroyd, G.L., Burns, G., and Smith, H.C., eds., Proceedings of the second endangered species and prairie conservation workshop, Natural History Occasional Paper, 15, Provincial Museum of Alberta, Edmonton, Alberta.

Colwell, M.A., and Oring, L.W., 1988a, Habitat use by breeding and migrating shorebirds in southcentral Saskatchewan: Wilson Bulletin, v. 100, p. 554-566.

Colwell, M.A., and Oring, L.W., 1988b, Return rates of prairie shorebirds: sex and species differences: Wader Study Group Bulletin, v. 55, p. 21-24.

Colwell, M.A., and Oring, L.W., 1990, Nest-site characteristics of prairie shorebirds: Canadian Journal of Zoology, v. 68, p. 297-302.

Colwell, M.A., Fellows, S.D., and Oring, L.W., 1988, Chronology of shorebird migration at Last Mountain National Wildlife Area, Saskatchewan, Canada: Water Study Group Bulletin, v. 52, p. 1822.

Conners, P.G., Myers, J.P., and Pitelka, F.A., 1979, Seasonal habitat use by Arctic Alaskan shorebirds: Studies in Avian Biology, v. 2, p. 101-111.

Conway, W.C., Smith, L.M., and Ray, J.D., 2005a, Shorebird breeding biology in wetlands of the Playa Lakes, Texas, USA: Waterbirds, v. 28, p. 129-138.

Conway, W.C., Smith, L.M., and Ray, J.D., 2005b, Shorebird habitat use and nest-site selection in the Playa Lakes Region: Journal of Wildlife Management, v. 69, p. 174-184.

Dahl, T.E., 1990, Wetlands: losses in the United States 1780’s to 1980’s: U.S. Department of the Interior, Fish and Wildlife Service, Washington, D.C.

Dahl, A.L., Johnson, D.H., Igl, L.D., Baer, K.L., Shaffer, T.L., Johnson, M.A., and Reynolds, R.E., 2003, American avocet nesting on constructed islands in North Dakota: Prairie Naturalist, v. 35, p. 95-105.

Danufsky, T., and Colwell, M.A., 2003, Winter shorebird communities and tidal flat characteristics at Humboldt Bay, California: Condor, v. 105, p. 117-129.

Daub, B.C., 1993, Effects of marsh area and characteristics on avian diversity and nesting success: Unpublished M.S. Thesis, University of Michigan, Ann Arbor, Michigan, 37 pp.

Davis, C.A., and Smith, L.M., 1998, Ecology and management of migrant shorebirds in the Playa Lakes Region of Texas: Wildlife Monographs, v. 140, p. 5-45.

Davis, C.A., and Smith, L.M., 2001, Foraging strategies and niche dynamics of coexisting shorebirds at stopover sites in the southern Great Plains: Auk, v. 118, p. 484-495.

Davis, D.E., Hanson, C.H., and Hansen, R.B., 2008, Constructed wetland habitat for American avocet and black-necked stilt foraging and nesting: Journal of Wildlife Management, v. 72, p. 143-151.

Davis, J.M., 1939, More shore-birds from the Humboldt Bay region: Condor, v. 41, p. 124.

Day, J.H., and Colwell, M.A., 1998, Waterbird communities in rice fields subjected to different postharvest treatments: Colonial Waterbirds, v. 21, p. 185-197.

Dechant, J.A., Zimmerman, A.L., Johnson, D.H., Goldade, C.M., Jamison, B.E., and Euliss, B.R., 2002, Effects of management practices on wetland birds: American Avocet: Northern Prairie Wildlife Research Center, Jamestown, North Dakota, 24 pp. 
DeLeon, M. T., 1996, Use of habitat and behavior of migrant shorebirds in North Dakota: Unpublished M.S. Thesis, Texas Tech University, Lubbock, Texas.

Demers, S.A., 2007, Space use of American avocets (Recurvirostra americana) in south San Francisco Bay, California: Unpublished M.S. Thesis, Humboldt State University, Humboldt, California.

Demers, S.A., Takekawa, J.Y., Ackerman, J.T., Warnock, N., and Athearn, N.D., 2010, Space use and habitat selection of migrant and resident American Avocets in San Francisco Bay: Condor, v. 112, p. 511-520.

Dinsmore, J.J., 1977, Notes on avocets and stilts in Tampa Bay, Florida: Florida Field Naturalist, v. 5, p. 25-30.

Dinsmore, J.J., Kent, T.H., Koenig, D., Peterson, P.C., and Roosa, D.M., 1984, Iowa birds: Iowa State University Press, Ames, Iowa.

Dodd, S.L., and Colwell, M.A., 1996, Seasonal variation in diurnal and nocturnal distributions of nonbreeding shorebirds at North Humboldt Bay, California: Condor, v. 98, p. 196-207.

Dole, D.A., 1986, Nesting and foraging behavior of American avocets: Unpublished M.A. Thesis, University of Montana, Missoula, Montana, 85 pp.

Eagles-Smith, C.A., Ackerman, J.T., Yee, J., and Adelsbach, T.L., 2009, Mercury demethylation in waterbird livers: dose-response thresholds and differences among species: Environmental Toxicology and Chemistry, v. 28, p. 568-577.

Edwards, D.D., and Bush, A.O., 1989, Helminth communities in avocets: importance of the compound community: Journal of Parasitology, v. 75, p. 225-238.

Eldridge, J., 1992, Management of habitat for breeding and migrating shorebirds in the Midwest: U.S.

Fish and Wildlife Service Leaflet, 13.2.14, 6 pp.

Elphick, C.S., and Oring, L.W., 1998, Winter management of Californian rice fields for waterbirds: Journal of Applied Ecology, v. 35, p. 95-108.

Evans, T.J., 1988, Habitat use and behavioral ecology of American avocets (Recurvirostra americana) wintering at Humboldt Bay, California: Unpublished M.S. Thesis, Humboldt State University, Arcata, California.

Evans, T.J., and Harris, S.W., 1994, Status and habitat use by American avocets wintering at Humboldt Bay, California: Condor, v. 96, p. 178-189.

Faanes, C.A., 1982, Avian use of Sheyenne Lake and associated habitats in central North Dakota: U.S. Fish and Wildlife Service, Resource Publication, 144, 24 pp.

Fairbrother, A., Fix, M., O’Hara, T., and Ribic, C.A., 1994, Impairment of growth and immune function of avocet chicks from sites with elevated selenium, arsenic and boron: Journal of Wildlife Diseases, $\mathrm{v}$. 30, p. 222-233.

Fellows, S., Stone, K., Jones, S., Damude, N., and Brown S., 2001, Central Plains/Playa Lakes regional shorebird conservation plan, Version 1.0, Online at http://www.fws.gov/shorebirdplan/RegionalShorebird/downloads/CPPLR.pdf. Accessed 11 July 2011.

Frederickson, L.H., and Reid, F.A., 1986, Wetland and riparian habitats: a nongame management overview: Pp. 59-96 in Hale, J.B., Best, L.B., and Clawson, R.L., eds., Management of nongame wildlife in the Midwest: a developing art, North Central Section Wildlife Society, Chelsea, Michigan.

Frederickson, L.H., and Taylor, T.S., 1982, Management of seasonally flooded impoundments for wildlife: U.S. Fish and Wildlife Service Resource Publication, no. 148, 29 pp.

Fry, D.M., 2001, An investigation into the ecotoxicology of selenium bioaccumulation in birds: 19981999 Technical Progress Reports, 1999, Online at ucblibrary3.berkeley.edu.

Gammonley, J.H., and Laubhan, M.K., 2002, Patterns of food abundance for breeding waterbirds in the San Luis Valley of Colorado: Wetlands, v. 22, p. 499-508. 
Garcia, A., and Canaris, G., 1987, Metazoan parasites of Recurvirostra americana Gmelin (Aves), from southwestern Texas and Monte Vista National Wildlife Refuge, Colorado, with a checklist of helminth parasites hosted by this species in North America: Southwestern Naturalist, v. 32, p. 85-91.

Garrett, K., and Dunn, J., 1981, Birds of southern California: status and distribution: Los Angeles Audubon Society, Los Angeles, California.

Gibbs, J.P., 1993, Importance of small wetlands for the persistence of populations of wetland-associated animals: Wetlands, v. 13, p. 25-31.

Gibson, F., 1971, The breeding biology of the American avocet (Recurvirostra americana) in central Oregon: Condor, v. 73, p. 444-454.

Gibson, F., 1978, Ecological aspects of the time budget of the American avocet: American Midland Naturalist, v. 99, p. 65-82.

Gill, R.E., and Handel, C.M., 1990, The importance of subarctic intertidal habitats to shorebirds: a study of the central Yukon-Kuskokwim Delta, Alaska: Condor, v. 92, p. 709-725.

Gilligan, J., Smith, M., Rogers, D., and Contreras, A., 1994, Birds of Oregon: status and distribution: Cinclus Publications, McMinnville, Oregon.

Giroux, J.F., 1985, Nest sites and superclutches of American avocets on artificial islands: Canadian Journal of Zoology, v. 63, p. 1302-1305.

Gordus, A.G., 1999, Selenium concentrations in eggs of American avocets and black-necked stilts at an evaporation basin and freshwater wetland in California: Journal of Wildlife Management, v. 63, p. 497-501.

Grant, G.S., 1982, Avian incubation: egg temperature, nest humidity, and behavioral thermoregulation in a hot environment: Ornithological Monographs, v. 30, p. 1-75.

Grinnell, J., Bryant, H.C., and Storer, T.I., 1918, The game birds of California: University of California Press, Berkeley, California.

Grover, P.B., 1979, Habitat requirements of charadriiform birds nesting on salt flats at Salt Plains National Wildlife Refuge: Unpublished M.S. Thesis, Northeastern Oklahoma University, Tahlequah, Oklahoma, 38 pp.

Grover, P.B., Jr., and Grover, M., 1981, Breeding charadriiform birds of the Great Salt Plains: Bulletin of the Oklahoma Ornithological Society, v. 15, p. 11-14.

Grover, P.B., and Knopf, F.L., 1982, Habitat requirements and breeding success of Charadriiform birds nesting at Salt Plains National Wildlife Refuge, Oklahoma: Journal of Field Ornithology, v. 53, p. 139-148.

Gunderson, M., Gunderson, E., Lease, E., and Moriarty, P., 1992, Nesting American avocets in Big Stone County: Loon, v. 64, p. 125-126.

Haig, S.M., Mehlman, D.W., and Oring, L.W., 1998, Avian movements and wetland connectivity in landscape conservation: Conservation Biology, v. 12, p. 749-758.

Hamilton, R.B., 1975, Comparative behavior of the American avocet and the black-necked stilt (Recurvirostridae): Ornithological Monographs, v. 17, p. 1-98.

Hands, H.M., Ryan, M.R., and Smith, J.W., 1991, Migrant shorebird use of marsh, moist-soil, and flooded agricultural habitats: Wildlife Society Bulletin, v. 19, p. 457-464.

Hannam, K.M., Oring, L.W., and Herzog, M.P., 2003, Impacts of salinity on growth and behavior of American avocet chicks: Waterbirds, v. 26, p. 119-125.

Harrington, B.A., 1992, A coastal aerial winter shorebird survey on the Sonora and Sinaloa coasts of Mexico: Water Study Group Bulletin, v. 67, p. 44-49.

Harrington, B., 2007, Conserving shorebirds on Department of Defense lands: Department of Defense Partners in Flight, Technical Series No. 3, 36 pp. 
Harvey, T.E., Miller, K.J., Hothem, R.L., Rauzon, M.J., Page, G.W., and Keck, R.A., 1992, Status and trends report on wildlife of the San Francisco Estuary: San Francisco Estuary Project, San Francisco, California.

Haukos, D.A., and Smith, L.M., 1993, Moist-soil management of playa lakes for migrating and wintering ducks: Wildlife Society Bulletin, v. 21, p. 288-298.

Heinz, G.H., 1996, Selenium in birds: Pp. 453-464 in Beyer, W.N., Heinz, G.H., and Redmon, A.W., eds., Interpreting environmental contaminants in animal tissues, Lewis Publications, Boca Raton, Florida.

Helmers, D.L., 1992, Shorebird management manual: Western Hemisphere Shorebird Reserve Network, Manomet, Massachusetts, 58 pp.

Henny, C.J., Anderson, T.W., and Crayon, J.J., 2005, Organochlorine pesticides, polychlorinated biphenyls, metals, and trace elements in waterbird eggs, Salton Sea, California, 2004: Hydrobiologia, v. 604, p. 137-149.

Hill, D., 1988, Population dynamics of the avocet (Recurvirostra avosetta) breeding in Britain: Journal of Animal Ecology, v. 57, p. 669-683.

Hill, D.A., 1989, Manipulating water habitats to optimize wader and wildfowl populations: Pp. 328-343 in Biological habitat reconstruction, Buckley, G.P., editor, Belhaven Press, London, United Kingdom. Hill, L.A., 1985, Breeding ecology of interior least terns, snowy plovers, and American avocets at Salt Plains National Wildlife Refuge, Oklahoma: Unpublished M.S. Thesis, Oklahoma State University, Stillwater, Oklahoma, 106 pp.

Hinojos, J.G., Campbell, B.K., and Canaris, A.G., 1993, Helminth parasites of the American avocet Recurvirostra americana (Aves), from the Salt Lake Basin, Utah: Journal of Parasitology, v. 79, p. 114-116.

Hirsch, K.V., and Fouchi, C.M., 1984, American avocets nesting in Traverse County: Loon, v. 56, p. 204-205.

Hoffman, D.J., 2002, Role of selenium toxicity and oxidative stress in aquatic birds: Aquatic Toxicology, v. 57, p. 11-26.

Hoffman, D.J., Ohlendorf, H.M., and Aldrich, T.W., 1988, Selenium teratogenesis in natural populations of aquatic birds in central California: Archives of Environmental Contamination and Toxicology, v. 17, p. 519-525.

Hoffman, D.J., Hallock, R.J., Rowe, T.G., Lico, M.S., Burge, H.L., and Thompson, S.P., 1990, Reconnaissance investigation of water quality, bottom sediment, and biota associated with irrigation drainage in and near Stillwater Wildlife Management area, Churchill County, Nevada, 1986-87: Water-Resources Investigations Report 89-4105, U.S. Geological Survey.

Hoffman, D.J., Marn, C.M., Marois, K.C., Sproul, E., Dunne, M., and Skorupa, J.P., 2002, Sublethal effects in avocet and stilt hatchlings from selenium-contaminated sites: Environmental Toxicology and Chemistry, v. 21, p. 561-566.

Hotker, H., 2000, Intraspecific variation in size and density of avocet colonies: effects of nest-distances on hatching and breeding success: Journal of Avian Biology, v. 31, p. 387-398

Janssen, R.B., 1987, Birds in Minnesota: University of Minnesota Press, Minneapolis, Minnesota, 352 pp.

Jehl, J.R., Jr., 1968, Relationships in the Charadrii (shorebirds): a taxonomic study based on color patterns of the downy young: San Diego Society of Natural History Memoirs, v. 3.

Johnsgard, P.A., 1979, Birds of the Great Plains: breeding species and their distribution: University of Nebraska Press, Lincoln, Nebraska. 
Johnsgard, P.A., 1980, A preliminary list of the birds of Nebraska and adjacent Plains states: University of Nebraska, Lincoln, Nebraska, 156 pp.

Kantrud, H.A., and Stewart, R.E., 1984, Ecological distribution and crude density of breeding prairie birds on prairie wetlands: Journal of Wildlife Management, v. 48, p. 426-437.

Kennard, J.H., 1975, Longevity records of North American birds: Bird-Banding, v. 46, p. 55-73.

Knapton, J.R., Jones, W.E., and Sutphin, J.W., 1988, Reconnaissance investigation of water quality, bottom sediment, and biota associated with irrigation drainage in the Sun River Area, west-central Montana, 1986-87: Water-Resources Investigations Report 87-4244, U.S. Geological Survey, Helena, Montana.

Koenen, M.T., 1995, Breeding ecology and management of least terns, snowy plovers, and American avocets: Unpublished M.S. Thesis, Oklahoma State University, Stillwater, Oklahoma, 108 pp.

Kondla, N.G., 1977, An unusual American avocet nest: Blue Jay, v. 35, p. 94-95.

Kondla, N.G., and Pinel, H.W., 1978, Clutch size of the American avocet in the prairie provinces: Blue Jay, v. 36, p. 150-153.

Koonz, W.H., 1985, Manitoba breeding range extension and large clutch size for an American avocet:

Blue Jay, v. 43, p. 57.

Kuyt, E., and Johns, B.W., 1992, Recent American avocet, Recurvirostra americana, breeding record in the Northwest Territories, with notes on avocet parasitism of mew gull, Larus canus, nests: Canadian Field-Naturalist, v. 106, p. 507-510.

Lambing, J.H., Jones, W.E., and Sutphin, J.W., 1988, Reconnaissance investigation of water quality, bottom sediment, and biota associated with irrigation drainage in Bowdoin National Wildlife Refuge and adjacent areas of the Milk River Basin, northeastern Montana, 1986-87: Water-Resources Investigations Report 87-4243, U.S. Geological Survey, Helena, Montana.

Lasky, W.R., 1952, A case of avian tuberculosis in an immature avocet: Condor, v. 54, p. 316.

Laubhan, M.K., and Gammonley, J.H., 2000, Density and foraging habitat selection of waterbirds breeding in the San Luis Valley of Colorado: Journal of Wildlife Management, v. 64, p. 808-819.

Lokemoen, J.T., 1993, Increasing waterfowl nesting success on islands and peninsulas: Pp. 1-7 in U.S. Fish and Wildlife Service Waterfowl Management Handbook, University of Nebraska, Lincoln, Nebraska.

Lokemoen, J.T., and Woodward, R.O., 1992, Nesting waterfowl and other water birds on natural islands in the Dakotas and Montana: Wildlife Society Bulletin, v. 20, p. 163-171.

Mahoney, S.A., and Jehl, J.R., Jr., 1985, Adaptations of migratory shorebirds to highly saline and alkaline lakes: Wilsons phalarope and American avocet: Condor, v. 87, p. 520-527.

Malcolm, J.M., 1982, Bird collisions with a power transmission line and their relation to botulism at a Montana wetland: Wildlife Society Bulletin, v. 10, p. 297-304.

McKenna, M.G., 1976, Avian mortality from wire collisions: North Dakota Outdoors, v. 39, p. 16-18. McVaugh, W., Jr., 1978, American avocet breeding at Pea Island, N.C.: Chat, v. 42, p. 31-32.

Meyer, J.L., Sale, M.J., Mulholland, P.J., and Poff, N.L., 1999, Impacts of climate change on aquatic ecosystem functioning and health: Journal of the American Water Resources Association, v. 35, p. 1373-1386.

Mitchell, H.H., 1917, Peculiar nesting habits of the avocet: Condor, v. 19, p. 101.

Mora, M.A., and Anderson, D.W., 1995, Selenium, boron, and heavy metals in birds from the Mexicali Valley, Baja California, Mexico: Bulletin of Environmental Contaminants and Toxicology, v. 54, p. 198-206.

Nimick, D.A., Lambing, J.H., Palawski, D.U., and Malloy, J.C., 1996, Detailed study of selenium in soil, water, bottom sediment, and biota in the Sun River Irrigation Project, Freezout Lake Wildlife 
Management Area, and Benton Lake National Wildlife Refuge, west-central Montana, 1990-92:

Water-Resources Investigations Report 95-4170, U.S. Geological Survey, Helena, Montana, 120 pp.

Ohlendorf, H.M., 1989, Bioaccumulation and effects of selenium on wildlife: Pp. 133-177 in Jacobs, L.W., ed., Selenium in agriculture and the environment, Special Publication 23, American Society of Agronomy and Soil Science Society of America, Madison, Wisconsin.

Ohlendorf, H.M., Hoffman, D.J., Saiki, M.K., and Aldrich, T.W., 1986a, Embryonic mortality and abnormalities of aquatic birds: apparent impacts of selenium from irrigation drainwater: Science of the Total Enivornment, v. 52, p. 49-63.

Ohlendorf, H.M., Hothem, R.L., Bunck, C.M., Aldrich, T.W., and Moore, J.F., 1986b, Relationships between selenium concentrations and avian reproduction: Transactions of the North American Wildlife and Natural Resources Conference, v. 51, p. 330-342.

Ohlendorf, H.M., Hothem, R.L., Aldrich, T.W., and Krynitsky, A.J., 1987, Selenium contamination of the grasslands, a major California waterfowl area: Science of the Total Environment, v. 66, p. 169183.

Ohlendorf, H.M., Hothem, R.L., and Welsh, D., 1989, Nest success, cause-specific nest failure, and hatchability of aquatic birds at selenium contaminated Kesterson Reservoir and a reference site: Condor, v. 91, p. 787-796.

Ohlendorf, H.M., Hothem, R.L., Bunck, C.M., and Marois, K.C., 1990, Bioaccumulation of selenium in birds at Kesterson Reservoir, California: Archives of Environmental Contaminants and Toxicology, v. 19, p. 495-507.

Ohlendorf, H.M., Hothem, R.L., and Welsh, D., 1989, Nest success, cause-specific nest failure, and hatchability of aquatic birds at selenium-contaminated Kesterson Reservoir and a reference site: Condor, v. 91, p. 787-796.

Oring, L., Harrington, B., Brown, S., and Hickey, C., eds., 2000, National Shorebird Research Needs: a Proposal for a National Research Program and Example High Priority Research Topics: Manomet Center for Conservation Sciences, http://www.Manomet.org/USSCP/files.htm.

Osmundson, B.D., 1990, Feeding of American avocets (Recurvirostra americana) during the breeding season: Unpublished M.S. Thesis, Utah State University, Logan, Utah, 91 pp.

Page, G.W., and Gill, R.E., Jr., 1994, Shorebirds in western North America: late 1800s to late 1900s: Studies in Avian Biology, v. 15, p. 147-160.

Palmer, R.S., 1967, Family Recurvirostridae: Pp. 150-152 in Stout, G.D., ed., Shorebirds of North America, Viking Press, New York, New York.

Paton, P.W.C., Kneedy, C., and Sorensen, E., 1992, Chronology of shorebird and ibis use of selected marshes at Great Salt Lake: Utah Birds, v. 8, p. 1-19.

Peterson, D. A., Jones, W.E., and Morton, A.G., 1988, Reconnaissance investigation of water quality, bottom sediment, and biota associated with irrigation drainage in the Kendrick Reclamation Project Area, Wyoming, 1986-87: Water-Resources Investigations Rpt. 87-4255, U.S. Geological Survey, Cheyenne, Wyoming.

Pinkowski, B.C., 1981, Further notes on Wilson's phalarope-American avocet feeding associations: Journal of Field Ornithology, v. 52, p. 147.

Plissner, J.H., Haig, S.M., and Oring, L.W., 2000, Postbreeding movements of American avocets and implications for wetland connectivity in the western Great Basin: Auk, v. 117, p. 290-298.

Porter, R.D., and White, C.M., 1973, The peregrine falcon in Utah, emphasizing ecology and competition with the prairie falcon: Brigham Young University Science Bulletin, Biological Series, v. 18, p. 1-74.

Presser, T.S., 1994, “The Kesterson Effect”: Environmental Management, v. 18, p. 437-454. 
Principe, W.L., Jr., 1977, A hybrid American avocet x black-necked stilt: Condor, v. 79, p. 128-129.

Quammen, M.L., 1982, Influence of subtle substrate differences on feeding by shorebirds on intertidal mudflats: Marine Biology, v. 71, p. 339-343.

Recher, H.F., 1966, Some aspects of the ecology of migrant shorebirds: Ecology, v. 47, p. 393-407.

Reed, J.M., and Oring, L.W., 1992, Reconnaissance for future breeding sites by spotted sandpipers: Behavioral Ecology, v. 3, p. 310-317.

Rehfisch, M.M., 1994, Man-made lagoons and how their attractiveness to waders might be increased by manipulating the biomass of insect benthos: Journal of Applied Ecology, v. 31, p. 383-401.

Rinella, F. A. and Schuler, C.A., 1992, Reconnaissance investigation of water quality, bottom sediment, and biota associated with irrigation drainage in the Malheur National Wildlife Refuge, Harney County, Oregon, 1988-89: Water-Resources Investigations Rpt. 91-4085, U.S. Geological Survey, Portland, Oregon.

Rinella, F. A., Mullins, W.H., and Schuler, C.A., 1994, Reconnaissance investigation of water quality, bottom sediment, and biota associated with irrigation drainage in the Owyhee and Vale Projects, Oregon and Idaho, 1990-91: Water-Resources Investigations Rpt. 93-4156, U.S. Geological Survey, Portland, Oregon.

Robbins, C.S., Bystrak, D., and Geissler, P.H., 1986, The Breeding Bird Survey: its first fifteen years, 1965-1979: Resource Publication 157, U.S. Department of the Interior, Fish and Wildlife Service, Washington, D.C.

Robinson, J.A., 1996, Shorebird populations and fragmented wetlands: Unpublished PhD Dissertation, University of Nevada, Reno, Nevada.

Robinson, J.A., 1997, American avocet (Recurvirostra americana): American Ornithologists’ Union, Washington, D.C.

Robinson, J.A., and Oring, L.W., 1996, Long-distance movements by American avocets and blacknecked stilts: Journal of Field Ornithology, v. 67, p. 307-320.

Robinson, J.A., and Oring, L.W., 1997, Natal and breeding dispersal of American avocets: Auk, v. 114, p. 416-430.

Robinson, J.A., Oring, L.W., Skorupa, J.P., and Boettcher, R., 1997, American Avocet (Recurvirostra americana): The Birds of North America Online, Poole, A., ed., Ithaca: Cornell Lab of Ornithology, Retrieved from the Birds of North America Online: http://bna.birds.cornell.edu/bna/species/275. Accessed on 5 April 2011.

Rosen, M.N., 1981, Botulism: Pp. 100-117 in Davis, J.W., Anderson, R.C., Karstad, L., and Trainer, D.O., eds., Infectious and parasitic diseases of wild birds, Iowa State University Press, Ames, Iowa. Rubega, M.A., and Oring, L.W., 2004, Excretory organ growth and implications for salt tolerance in hatchling American avocets Recurvirostra americana: Journal of Avian Biology, v. 35, p. 13-15.

Rubega, M.A., and Robinson, J.A., 1997, Water salinization and shorebirds: emerging issues: Pp. 45-54 in Reed, J.M., Warnock, N., and Oring, L.W., eds., Conservation and management of shorebirds in the western Great Basin of North America, International Wader Studies, v. 9.

Rundle, W.D., and Frederickson, L.H., 1981, Managing seasonally flooded impoundments for migrant rails and shorebirds: Wildlife Society Bulletin, v. 9, p. 80-87.

Salt, W.R., and Salt, J.R., 1976, The birds of Alberta: Hurtig Publishers, Edmonton, Alberta, 498 pp.

Sauer, J.R., Schwartz, S., Peterjohn, B.G., and Hines, J.E., 1996, The North American Breeding Bird Survey Home Page, Version 95.1, Patuxent Research Center, Laurel, Maryland, Online at http://www.pwrc.usgs.gov/BBS/index.html. Accessed 11 July 2011. 
Sauer, J.R., Hines, J.E., Fallon, J.E., Pardieck, K.L., Ziolkowski, D.J., Jr., and Link, W.A., 2011, The North American Breeding Bird Survey, Results and Analysis 1966 - 2009: Version 3.23.2011. Online at http://www.mbr-pwrc.usgs.gov/bbs/bbs.html. Accessed on 12 July 2011.

Schroeder, R. A., Palawski, D.U., and Skorupa, J.P., 1988, Reconnaissance investigation of water quality, bottom sediment, and biota associated with irrigation drainage in the Tulare Lake Bed area, southern San Joaquin Valley, California, 1986-87: Water Resources Investigations Rpt. 88-4001, U.S. Geological Survey, Sacramento, California.

See, R.B., Naftz, D.L., Peterson, D.A., Crock, J.G., and Erdman, J.A., 1992, Detailed study of selenium in soil, representative plants, water, bottom sediment, and biota in the Kendrick Reclamation Project Area, Wyoming, 1988-1990: Water-Resources Investigations Report 91-4131, U.S. Geological Survey, Cheyenne, Wyoming, $142 \mathrm{pp}$.

Seiler, R.L., and Skorupa, J.P., 1995, Identification of areas at risk for selenium contamination in the western United States: Pp. LL85-LL94 in Water Resources at Risk, American Institute of Hydrology, Denver, Colorado.

Setmire, J.G., Schroeder, R.A., Densmore, J.N., Goodbred, S.L., Audet, D.J., and Radke, W.R., 1993, Detailed study of water quality, bottom sediment, and biota associated with irrigation drainage in the Salton Sea Area, California, 1988-90: Water-Resources Investigations Report 93-4014, U.S. Geological Survey, Sacramento, California.

Shipley, F.S., 1984, The 4-egg clutch limit in the Charadrii: an experiment with American avocets: Southwestern Naturalist, v. 29, p. 143-147.

Shuford, W.D., Page, G.W., Kjelmyer, J., and Hickey, C.M., 1994a, Seasonal abundance and habitat use of shorebirds in California’s Central Valley, November 1993 to August 1994: Point Reyes Bird Observatory, Stinson Beach, California.

Shuford, W.D., Roy, V.L., Page, G.W., and Paul, D.S., 1994b, A comprehensive survey of shorebirds in wetlands at Great Salt Lake, Utah, 10-11 August 1994: Contribution no. 655, Point Reyes Bird Observatory, Stinson Beach, California.

Shuford, W.D., Warnock, N., and McKernan, R.L., 2004, Patterns of shorebird use of the Salton Sea and adjacent Imperial Valley, California: Studies in Avian Biology, v. 27, p. 61-77.

Sidle, J.G., and Arnold, P.M., 1982, Nesting of the American avocet in North Dakota: Prairie Naturalist, v. 14, p. 73-80.

Skagen, S.K., and Knopf, F.L., 1993, Toward conservation of midcontinental shorebird migrations: Conservation Biology, v. 7, p. 533-541.

Skagen, S.K., and Knopf, F.L., 1994, Migrating shorebirds and habitat dynamics at a prairie wetland complex: Wilson Bulletin, v. 106, p. 91-105.

Skagen, S.K., Sharpe, P.B., Waltermire, R.G., and Dillon, M.B., 1999, Biogeographical profiles of shorebird migration in midcontinental North America: Biological Science Report USGS/BRD/BSR2000-0003, U.S. Government Printing Office, Denver, Colorado, 167 pp.

Skorupa, J.P., 1998, Selenium poisoning of fish and wildlife in nature: lessons from twelve real-world examples: Pp. 315-354 in Frankenberger, W.T., Jr., and Engberg, R.A., eds., Environmental chemistry of selenium, Marcel Dekker, Inc., New York, New York.

Skorupa, J.P., and Ohlendorf, H.M., 1991, Contaminants in drainage water and avian risk thresholds: Pp. 345-368 in The economics and management of water and drainage in agriculture (Dinar, A., and Zilbermann, D., editors), Kluwer Academic Publication, Norwell, Massachusetts.

Sordahl, T.A., 1980, Antipredator behavior and parental care in the American avocet and black-necked stilt (Aves: Recurvirostridae): Unpublished PhD Dissertation, Utah State University, Logan, Utah. 
Sordahl, T.A., 1981, Phenology and status of the shorebirds in northern Utah: Western Birds, v. 12, p. 173-180.

Sordahl, T.A., 1982, Antipredator behavior of American avocet and black-necked stilt chicks: Journal of Field Ornithology, v. 53, p. 315-325.

Sordahl, T.A., 1984, Observations on breeding site fidelity and pair formation in American avocets and black-necked stilts: North American Bird Bander, v. 9, p. 8-11.

Sordahl, T.A., 1986, Evolutionary aspects of avian distraction display: variation in American avocet and black-necked stilt antipredator behavior: Pp. 87-112 in Deception: perspectives on human nonhuman deceit (Mitchell, R.W., and Thompson, N.S., editors), State University of New York Press, Albany, New York.

Sordahl, T.A., 1988, The American avocet (Recurvirostra americana) as a paradigm for adult automimicry: Evolutionary Ecology, v. 2, p. 189-196.

Sordahl, T.A., 1990, Sexual differences in antipredator behavior of breeding American avocets and black-necked stilts: Condor, v. 92, p. 530-532.

Sordahl, T.A., 1994, Eggshell removal behavior of American avocets and black-necked stilts: Journal of Field Ornithology, v. 65, p. 461-465.

Sordahl, T.A., 1996, Breeding biology of the American avocet and black-necked stilt in northern Utah: Southwestern Naturalist, v. 41, p. 348-354.

Sordahl, T.A., 2004, Field evidence of predator discrimination abilities in American avocets and blacknecked stilts: Journal of Field Ornithology, v. 75, p. 376-385.

Stewart, R.E., and Kantrud, H.A., 1965, Ecological studies of waterfowl populations in the prairie potholes of North Dakota: U.S. Fish and Wildlife Service, Bureau of Sport Fisheries and Wildlife, 1965 Progress Report, 14 pp.

Svingen, P., 1998, The American avocet in Minnesota: Loon, v. 70, p. 11-20.

Swanson, G.A., and Meyer, M.I., 1977, Impact of fluctuating water levels on feeding ecology of breeding blue-winged teal: Journal of Wildlife Management, v. 41, p. 426-433.

Takekawa, J., Miles, A., Tsao-Melcer, D., Schoellhamer, C., Fregien, S., and Athearn, N.D., 2009, Dietary flexibility in three representative waterbirds across salinity and depth gradients in salt ponds of San Francisco Bay: Hydrobiologia, v. 626, p. 155-168.

Tulare Lake Drainage System, 1996, Supplement to the 1995 annual report: Tulare Lake Drainage District, Corcoran, California.

U.S. Fish and Wildlife Service, 1992, An overview of irrigation drainwater techniques, impacts on fish and wildlife resources, and management options: Division of Environmental Contaminants, U.S. Fish and Wildlife Service, Washington, D.C.

Vermeer, K., 1971, Large American avocet clutches at Dowling Lake, Alberta: Blue Jay, v. 29, p. 88.

Warnock, N., Haig, S.M., and Oring, L.W., 1998, Monitoring species richness and abundance of shorebirds in western Great Basin: Condor, v. 100, p. 589-600.

Weber, L.M., and Haig, S.M., 1996, Shorebird use of South Carolina managed and natural coastal wetlands: Journal of Wildlife Management, v. 60, p. 73-82.

Weber, M.J., 1978, Non-game birds in relation to habitat variation on South Dakota wetlands: Unpublished M.S. Thesis, South Dakota State University, Brookings, South Dakota, 54 pp.

Weber, M.J., Vohs, P.A., Jr., and Flake, L.D., 1982, Use of prairie wetlands by selected bird species in South Dakota: Wilson Bulletin, v. 94, p. 550-554.

Weller, M.W., 1999, Wetland birds: habitat resources and conservation implications: Cambridge University Press, Cambridge, New York, 271 pp. 
Wells, K.M., 2003, The effects of salinity on territoriality, nest placement, reproductive success, and foraging behavior of American avocets (Recurvirostra americana) breeding at an inland wetland complex: Unpublished M.A. Thesis, University of Nebraska, Omaha, Nebraska.

Wetmore, A., 1925, Food of American phalaropes, avocets, and stilts: Bulletin 1359, U.S. Department of Agriculture, Washington, D.C.

White, D.H., King, K.A., and Prouty, R.M., 1980, Significance of organochlorine and heavy metal residues in wintering shorebirds at Corpus Christi, Texas, 1976-77: Pesticides Monitoring Journal, v. 14, p. 58-63.

White, D.H., Mitchell, C.A., and Kaiser, T.E., 1983, Temporal accumulation of organochlorine pesticides in shorebirds wintering on the South Texas coast, 1979-1980: Archives of Environmental Contamination and Toxicology, v. 12, p. 241-245.

Williams, M.L., Hothem, R.L., and Ohlendorf, H.M., 1989, Recruitment failure in American avocets and black-necked stilts nesting at Kesterson Reservoir, California, 1984-1985: Condor, v. 91, p. 797802.

Winternitz, B.L., 1998, American avocet, Recurvirostra americana: Pp. 174-175 in Kingery, H.E., ed., Colorado Breeding Bird Atlas, Colorado Bird Atlas Partnership, Copublished by Colorado Division of Wildlife, Denver, Colorado.

Winton, B.R., and Leslie, D.M., Jr., 1997, Breeding ecology of American avocet (Recurvirostra americana) in north-central Oklahoma: Bulletin of the Oklahoma Ornithological Society, v. 30, p. 2532.

Wu, L., Chen, J., Tanji, K.K., and Banuelos, G.S., 1995, Distribution and biomagnification of selenium in a restored upland grassland contaminated by selenium from agricultural drain water: Environmental Toxicology and Chemistry, v. 14, p. 733-742. 


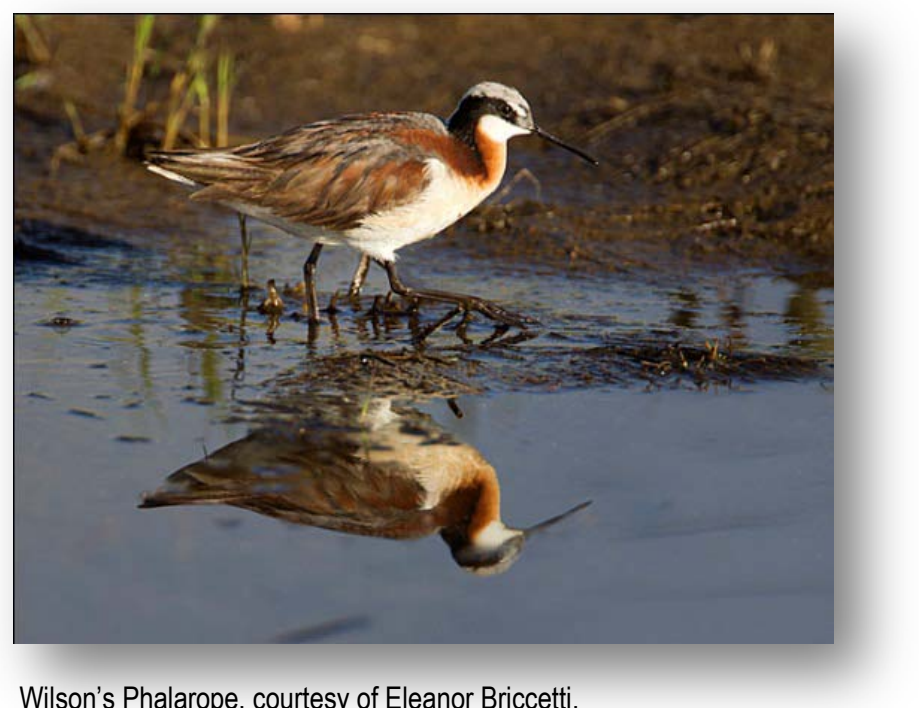

\section{Wilson's Phalarope (Phalaropus tricolor)}

\section{Introduction}

Wilson's Phalarope (Phalaropus tricolor) is the largest and most terrestrial of the three phalarope species (Colwell and Jehl, 1994). All three species of phalaropes are known for their reversed sex-role mating system. The larger and more brightlyplumaged females compete for mates and are sometimes polyandrous, whereas males provide all the parental care (Johns, 1969). Unlike the other two phalarope species [Rednecked Phalarope ( $P$. lobatus) and Red Phalarope ( $P$. fulicarius)], which have Holarctic breeding ranges and pelagic nonbreeding distributions, Wilson's phalaropes breed exclusively within the Nearctic, and its nonbreeding distribution is entirely continental. Wilson's Phalaropes breed at shallow wetlands of interior western North America, but for most of the year the species is a salt-lake specialist (Colwell and Jehl, 1994). After the breeding season, virtually all adults undertake a molt migration and stage, often in huge flocks, at hypersaline/alkaline lakes of western North America, before migrating to similar wintering habitats mainly in the altiplano of Bolivia and Argentina. Small numbers winter at wetlands in the pampas and as far south as Tierra del Fuego. Relatively little is known about habitats in wintering areas for this species. Loss of prairie wetlands in the early to mid-twentieth century reduced overall habitat for this phalarope, and likely its numbers as well. However, its range has expanded dramatically in recent decades, with breeding occurring from regions as far east as Massachusetts, as far south (and west) as New Mexico, and as far north as Alaska and the Yukon (Colwell and Jehl, 1994).

A simple Google search on the Internet for "Phalaropus tricolor" revealed 167,000 results and a Google Scholar search provided 1,180 results (accessed 11 July 2011). “Wilson’s phalarope” revealed 150,000 results through Google and 2,020 results through Google Scholar (accessed 11 July 2011).

\section{Natural History}

\section{Morphology}

Wilson's phalaropes are small (22 to $24 \mathrm{~cm}$ in length), aquatic sandpipers with toes bordered by a narrow fleshy fringe, needle-like bills, and white underparts and rumps (Colwell and Jehl, 1994). During the breeding season, the larger females are also more brightly plumaged than the males. Breeding females possess pale blue-gray foreheads and crowns; a white streak trails from the back of the head, down the nape to the upper back; the throat is cinnamon buff-colored; scapulars and mantle are chestnut; the wings are gray brown; underparts and rump are white; the tail is pale grayish; bill is black; and legs are grayish to black (Colwell and Jehl, 1994). Breeding males are smaller in overall size and less brightly plumaged than females, with considerable individual variability. The sexes are similar in basic (nonbreeding) plumage (Colwell and Jehl, 1994). 


\section{Distribution}

Wilson's phalaropes breed from the southern Yukon Territories through British Columbia, southcentral Alberta, and southern Manitoba, south to central California, southern Nevada, southern Colorado, northern New Mexico, and northern Texas, and east to central Kansas, northwestern Iowa, and northwestern Minnesota (Dechant and others, 2002). They also breed from eastern Wisconsin and northeastern Illinois, east to Michigan, northern Ohio, eastern Ontario, and northern New York (National Geographic Society, 1987). An expanding population breeds around the Great Lakes and recently reached southwest Quebec (first recorded breeding in 1974). Outside the usual breeding range, isolated nests have been recorded from many areas, including southeastern Alaska east to James Bay, Ontario, and New Brunswick, south to central California, Arizona, New Mexico, Texas, Ohio, and Massachusetts. Recently, phalaropes have been suspected of nesting in Delaware, New Jersey, and New York (Veit and Peterson, 1993).

In Colorado, phalaropes summer across much of the state, although their breeding status is not always easy to determine (Nelson, 1998). They prefer to nest in moist sedge and rush meadows characterized by low plant height (Nelson, 1998). Low sedges may grow in highly alkaline soil. Adjacent open water is also a habitat requirement (Bent, 1927). In Colorado, the known range in the late 1800s restricted phalaropes to the northeast quarter of the state (Cooke, 1897), but by 1965 they were regarded as common nesters not only in prairie marshes but also mountain valleys. That situation has changed; the current Colorado Breeding Bird Atlas map indicates they nest in scattered places across much of the state, but nesting has subsided somewhat in the plains where many marshes have been converted to wheat fields, corn patches, or subdivisions. Colorado nesting habitat currently centers on the intermountain valleys at 7,000 - 10,000 ft (2135-2048 m). Nesting strongholds during the Atlas surveys included North Park, San Luis Valley (SLV), Gunnison Valley, and the Yampa watershed. Nest-finding for this species was considered exasperating by Bent (1927). Males sit tight when incubating, and nests avoid human detection unless the male flushes at the last possible moment. Young stay in heavy vegetation until old enough to fly, and shortly after fledging depart the breeding grounds. Six out of ten breeding confirmations from the Colorado Breeding Bird Atlas were from Alamosa, Monte Vista, and Arapahoe NWRs.

\section{Migration}

Wilson's phalaropes are transequatorial migrants (Colwell and Jehl, 1994). They are one of two shorebird species to undergo molt migration and they are one of the earliest fall migrants (Jehl, 1987; 1990). Their post-breeding migratory movements are staggered by sex: females depart the breeding area and arrive at staging areas by mid-June, followed by adult males, and finally, the juveniles (Colwell and Oring, 1988a; Jehl, 1988). The southbound migration is characterized by large numbers of adults staging at hypersaline lakes (for example, the Great Salt Lake, Utah; Mono Lake, California) of western North America, where abundant food enables them to rapidly molt and store fat for migration. Wilson's phalaropes amass greater fat loads (up to 54 percent) than the maximal 45 percent fat load necessary for most shorebird migrants (Jehl, 1997). For a brief period of time, they can become too heavy to fly. Southward migration of adults is characterized by a rapid and direct nonstop flight from the staging areas in the United States to coastal, western South America. The adults evidently use a "Great Circle Route" across the Pacific as indicated by a virtual absence of fall records of phalaropes from Central America and northern South America. Juvenile movements are slower and cross a broader overland front in western and central United States, through northern Mexico, and Central America to northern South America. Adults arrive in South America in early August after a flight of approximately 54 hours. Juveniles arrive in late August. The spring migration northward is largely overland and through the 
highlands of South America in mid-March, through Central America or across the Gulf of Mexico, through the intermountain west and southern plains (Oring and Davis, 1966; Skagen and Knopf, 1993), where 90 percent of the population is thought to pass through Cheyenne Bottoms in Kansas (Morrison and Myers, 1987) in some years. Breeding areas are first occupied in late April to early May.

\section{Habitat}

During the breeding season, Wilson's phalaropes use both fresh and alkali wetlands with three characteristics: open water, emergent vegetation, and open shoreline (Saunders, 1914; Stewart and Kantrud, 1965; Hohn, 1967; Stewart, 1975; Prescott and others, 1995; Naugle, 1997). Nesting habitat varies widely, including wetlands, wet meadows, upland grasslands, and road rights-of-way (Roberts, 1932; Bent, 1962; Hohn, 1967; Stewart, 1975; Murray, 1983; Bomberger, 1984; Colwell, 1987; Colwell and Oring, 1990; Einemann, 1991; Faanes and Lingle, 1995; Dinsmore and Schuster, 1997). Wilson’s phalaropes occasionally occur in Conservation Reserve Program (CRP) fields and dense nesting cover (Johnson and Schwartz, 1993; Prescott and others, 1993). In North Dakota, Wilson phalarope densities were highest in undifferentiated tillage wetlands (wetlands with frequently tilled soils), followed by temporary, seasonal, semipermanent, fen, alkali, and permanent wetlands (Kantrud and Stewart, 1984). Wilson's phalaropes often occupied the peripheral low-prairie and wet-meadow areas of most classes of wetlands in North Dakota. In South Dakota, the occurrence of Wilson's phalaropes was associated positively with the presence of seasonal and semipermanent wetlands, stock ponds, and intermittent streams; area of alfalfa (Medicago sativa) hayland; area of surface water; and the percentage of grazed shoreline (Weber, 1978; Weber and others, 1982). In eastern South Dakota, the probability of occurrence of Wilson's phalaropes in semipermanent wetlands was related positively to the proportion of untilled uplands and the number of emergent hydrophyte species (for example, willow [Salix spp.]) composing >10 percent of the vegetated wetland area; Wilson's phalaropes were associated negatively with wetlands dominated by thick-stemmed plants (for example, cattail [Typha spp.] and river bulrush [Schoenoplectus fluviatilis]) (Naugle, 1997). Within seasonal wetlands, the probability of occurrence of Wilson's Phalaropes was related negatively to wetlands dominated by thick-stemmed plants (Naugle, 1997). In Colorado, Wilson's phalaropes preferred seasonal wetlands and habitats dominated by baltic rush (Juncus balticus), sedges (Carex spp.), and grasses $<40 \mathrm{~cm}$ tall over semipermanent wetlands, habitats dominated by cattail and softstem bulrush (Schoenoplectus tabernaemontani) $>40 \mathrm{~cm}$ tall, saltgrass habitats, or upland shrub habitats (Laubhan and Gammonley 2000).

Nest site selection varies seasonally for this species. Wilson's phalaropes nest in upland vegetation early in the breeding season and wet-meadow vegetation later in the season (Colwell and Oring, 1990). They usually nest <100 m from shoreline (Hohn, 1967; Hatch, 1971; Colwell and Oring, 1990; Eldridge, 1992). They also exhibit annual variation in nest site selection, moving to deeper, more permanent wetlands in dry years (Hohn, 1967; Colwell, 1991). Nest sites in Nebraska were in wet sedge meadows (Faanes and Lingle, 1995). In North Dakota and Iowa, Wilson's phalaropes nested in wetlands associated with river floodplains (Murray, 1983; Koenig, 1984). In Alberta, Saskatchewan, and North Dakota, the birds nested in grasses of various heights on islands or in wet-meadow zones around lakes and wetlands; in Saskatchewan, brood rearing occurred in patches of foxtail barley (Hordeum jubatum) (Bent, 1962; Hohn, 1967; Kagarise, 1979; Colwell 1987). In Saskatchewan, Colwell and Oring (1990) found that nest sites of Wilson's phalaropes had taller, denser, and more homogeneous vegetation and less bare ground than randomly selected sites. In the Nebraska sandhills, however, nest sites had shorter vegetation than random sites (Bomberger, 1984). A table near the end of this account lists the specific habitat characteristics for Wilson's phalaropes by study. 
Naugle and others (1999) conducted bird surveys throughout South Dakota in 1995 and 1996 to assess the effects of woody vegetation encroachment on nongame wetland birds. They found that wetland bird species richness decreased as the extent of woody vegetation encompassing wetland perimeters increased. Logistic regression analyses indicated that Wilson's phalaropes were less likely to occur in wetlands surrounded by trees.

\section{Foraging Habits}

The main foods eaten by Wilson's phalaropes are small aquatic invertebrates (dipterans, crustaceans, particularly brine flies and brine shrimp) in freshwater or hypersaline environments (Colwell and Jehl, 1994). They also feed on some terrestrial invertebrates and occasionally on seeds of aquatic plants (Colwell and Jehl, 1994; O’Brien and others, 2006). Wilson's phalaropes are the most terrestrial of the 3 phalarope species, but are still highly aquatic (Baldassare and Fischer, 1984; Colwell and Oring, 1988b). On the breeding grounds they forage in open-water, flooded meadows, and less frequently in upland habitats and long beaches (Colwell, 1987; Colwell and Oring, 1988b). Males use a wide array of aquatic and terrestrial habitats whereas females are more aquatic (Colwell, 1987). Wilson's phalaropes often forage in close proximity (commensally) with other aquatic species, including the northern shoveler (Anas clypeata; Siegfried and Batt, 1972), American avocet (Williams, 1953; Pinkowski, 1981), Chilean flamingoes (Phenicopterus chilensis; Hurlbert and others, 1984), and blue-winged teal (Anas discors).

Unlike most shorebirds, Wilson's phalaropes forage principally while swimming. The birds forage visually, except when probing soft substrates, and use the surface tension of water between their mandibles to transport prey from the beak tip to their mouths (Rubega and Obst, 1993; Rubega, 1997; Estrella and others, 2007). Foraging methods include typical phalarope "spinning," chasing and pecking prey from water or mud surfaces (Wetmore, 1925), standing still and lunging/stabbing passing flies, probing soft substrates, and rarely, "hawking” insects (Benning, 1974) and scything in the manner of avocets. Spinning behavior is rarely used at Mono Lake and other major staging areas where food is abundant. Foraging behavior varies with location, season, and environmental conditions, which influence the available prey (Colwell and Jehl, 1994).

\section{Breeding}

In the central and northern Great Plains (Minnesota, Nebraska, and North Dakota), Wilson's phalaropes arrive on the breeding grounds from mid-April to early May and depart from mid-August to early September (Roberts, 1932; Howe, 1972; Johnsgard, 1980; Murray, 1983). In Alberta, Manitoba, and Saskatchewan, Wilson's phalaropes arrive on the breeding grounds from late April to early May and are observed until early September (Hohn, 1967; Maher, 1974; Reynolds and others, 1986; Colwell, 1987; Colwell and Oring, 1988a; 1988b). Females arrive on the breeding grounds earlier than males (Reynolds et al. 1986, Colwell 1987), and commonly depart from breeding areas earlier than males, usually from early June to early July (Hohn, 1967; Howe, 1972; Colwell, 1987; Colwell and Oring, 1988a; 1988b).

Most of the information on breeding biology is based on a 6-year banding study in Saskatchewan near the northern extent of the breeding range (Reynolds and others, 1986; Colwell and Oring, 1988a; 1988b; 1988c; 1988d; 1988e; 1988f; Colwell and Oring, 1990; Colwell, 1992). Early season female-biased sex ratios and intense competition among females for mates suggest that birds arrive unpaired. The duration and types of interactions between pair members vary greatly. The average interval between pair formation and clutch completion is 8 days (range 7-10). About half (16/29) of the females desert mates upon clutch completion. 
Wilson's phalaropes may renest after nest failure, and females are capable of laying multiple clutches (Colwell and Jehl, 1994). Incubation and brood-rearing is performed exclusively by males (Delehanty and others, 1998). Polyandry was first documented in the species in Saskatchewan, where a color-banded female laid two clutches with two individual males (Colwell, 1986a; Colwell, 1987). Philopatry is uncommon in Wilson's phalaropes, although males return to breeding areas in successive years more often than females (Colwell, 1987; Colwell and Oring, 1988b). Of 154 adult male phalaropes banded over $4 \mathrm{yr}$ in Saskatchewan, 16 percent returned to their previous breeding area in successive years, whereas only 2 percent of 69 banded adult females returned (Colwell 1987).

The Wilson's phalarope is an accidental and unsuitable host of the brown-headed cowbird (Molothrus ater), an obligate brood parasite (Friedmann, 1963; Hatch, 1971). In North Dakota, 0 of 20 nests were parasitized (M. Winter and D. H. Johnson, unpublished data, cited in Colwell and Jehl, 1994). In Saskatchewan, 1 percent of 386 nests were parasitized (Colwell and Jehl, 1994). One record of multiple parasitism has been reported (Friedmann, 1963). One case of intraspecific brood parasitism was reported by Colwell (1986a) in Saskatchewan.

\section{Demography \& Population Status}

Data on longevity of Wilson's phalaropes is restricted to individuals returning to a Saskatchewan site where they were banded (Colwell and Oring, 1988f). Most males (87 percent, $n=55$ ) and females (88 percent, $n=8$ ) were observed breeding for one year after banding as adults, 7 percent of males and 12 percent of females were present in two consecutive years, and 6 percent of males and no females were present for three years. These estimates were probably low because of dispersal to new, unmonitored breeding sites (Colwell and Jehl, 1994). Many other sandpiper species live 8-10 years in the wild (Colwell and Jehl, 1994). No estimates of annual survival for Wilson's phalaropes exist, according to the extensive literature search conducted for this project.

There is considerable temporal and spatial variation in breeding densities of Wilson's phalaropes owing to use of ephemeral wetlands and a nonterritorial mating system. Estimated nest densities vary between 0 and 45 at a 40 ha ephemeral wetland, and 55-110 at a 100-ha permanent wetland in Saskatchewan (Colwell, 1986b; 1991; Colwell and Oring, 1988a). Breeding densities may be lower than this because of renesting by some males.

Several population estimates for Wilson's phalaropes have been published. Jehl (1988) estimated North American populations at 1.5 million birds in fall, based upon counts from major staging areas. Jehl's estimate was based on a total count of 741,000 individuals (primarily adults) reported from all major known staging sites in North American in July 1986. Stewart and Kantrud (1972) estimated 172,000 breeding pairs in North Dakota. The great majority of adult Wilson's phalaropes is thought to stage at the Great Salt Lake, Utah, Mono Lake, California, and/or Lake Albert, Oregon, before making a nonstop flight to South America. Their concentrations at these few localities provides an exceptional opportunity for studying trends species-wide (Jehl, 1999). Observations from 1980 through 1997 indicated that numbers of staging adults approximated 500,000-600,000 in the 1980s, then declined by about half in the 1990s.

Currently, it is unclear whether Wilson's phalarope populations are increasing, declining, or stable (Lesterhuis and Clay, 2010). While its breeding range has considerably expanded in recent decades, the species no longer breeds at a number of former sites, and the population has not shown a marked increase. At the national level, Wilson's phalaropes have been considered a "Species of High Concern" in the United States and Canadian Shorebird Conservation Plans (Donaldson and others, 2000; Brown and others, 2001; USFWS, 2004). The Breeding Bird Survey (BBS) regional trend analysis for Wilson's phalaropes along 35 Colorado routes from 1966 to 1999 showed a negative trend 
estimate of -1.2 (-5.0, 2.7; 95 percent CI) (Sauer and others, 2011). From 1999 to 2009, the trend was also negative and estimated to be -0.2 (-6.9, 9.0; 95 percent CI). However, the regional credibility measure for this species was in the "yellow" category meaning that data have deficiencies such as overall low abundances of phalaropes per route and/or the results were too imprecise to detect long-term trends.

\section{Threats}

\section{Sources of Mortality}

The potential predators of eggs and young of Wilson' phalaropes include garter snake (Thamnophis spp.), various gulls (Larus spp.), common crow (Corvus brachyrhynchos), red-winged blackbird (Agelaius phoeniceus), yellow-headed blackbird (Xanthocephalus xanthocephalus), striped skunk (Mephitis mephitis), Franklin's ground squirrel (Spermophilus franklini), Richardson's ground squirrel (S. richardsoni), and raccoon (Procyon lotor) (Kagarise, 1979; Colwell and Oring, 1988).

Clutch mortality is predominately due to predation (average 59 percent) (Colwell and Jehl, 1994). The next highest losses for clutches (average 17 percent) are due to abandonment, which often follows partial clutch loss to predators (Colwell and Oring, 1988a; Delehanty and Oring, 1993).

Predation rates for nests are highest during the years of greatest human activity around nests (Colwell, 1992). In Saskatchewan, there was no association between nest success and degree of concealment from predators provided by vegetation in the immediate vicinity of the nest cup.

The responses of Wilson's phalaropes to predators vary seasonally. They are fairly tolerant of humans on nesting grounds and shortly after arriving at staging lakes prior to weight gain for migration. However, they are very wary of humans and gulls shortly before departure to South America, when they are obese and less mobile (Colwell and Jehl, 1994). The major diurnal predators of phalaropes at salt lake staging areas include peregrine falcons, prairie falcons, and northern harriers.

\section{Contaminants}

Wilson's phalaropes are found in close proximity to agricultural areas, especially during the breeding season, where the widespread use of agrochemicals and irrigation water may be causing unrecognized mortality or other problems (Lesterhuis and Clay, 2010). Agricultural practices can result in elevated sedimentation rates (Martin and Hartman, 1986; Gleason and Euliss, 1996), and drift of agricultural chemicals into wetlands (Grue and others, 1989), large inputs of nutrients (Neely and Baker, 1989), unnatural variance in water-level fluctuation (Euliss and Mushet, 1996), and altered vegetative communities (Kantrud and Newton, 1996).

In Wyoming, high levels of selenium in lakes appeared to lead to high levels in the eggs (>13 $\mu \mathrm{g} / \mathrm{g}$ ) and livers $(>30 \mu \mathrm{g} / \mathrm{g}$ ) of adult Wilson's phalaropes (See and others, 1992). One adult, dead bird had a liver selenium content of $>30 \mu \mathrm{g} / \mathrm{g}$, a level associated with biological risk. Mean concentrations of selenium $>13 \mu \mathrm{g} / \mathrm{g}$ dry weight were associated with embryo deformities. Of six eggs collected over 2 years, selenium concentrations ranged from 5 to $19.9 \mu \mathrm{g} / \mathrm{g}$ dry weight and averaged $11.7 \mu \mathrm{g} / \mathrm{g}$ dry weight. Irrigation of soils with a high selenium content caused leaching of selenium from the soil to the ground water. Selenium discharge from basins was related to intensity of irrigation (measured by the area of irrigated land) and the concentration of selenium in the ground water. Also in Wyoming, mortality of Wilson's phalarope was observed after fenthion, a chemical used to control mosquitoes (Culicidae), was aerially applied at a rate of $47 \mathrm{~g} / \mathrm{ha}$ to an irrigated meadow (DeWeese and others, 1983). Fenthion is a cholinesterase inhibitor, and activity of brain cholinesterase was significantly lower for 15 days post spray in phalaropes collected from treated areas than in phalaropes from control areas. 


\section{Loss and Degradation of Wetlands}

The contraction of breeding range for the Wilson's Phalarope in the early $20^{\text {th }}$ century is likely linked to the loss of prairie wetlands (Dahl and Johnson, 1991). For example, in Iowa there has been an 89 percent loss in wetlands since the 1870s. The recent range shifts for the Wilson's phalarope suggests this species is sufficiently vagile in discovering new habitats (Skagen and Knopf, 1993). In some areas of western North America, water diversion or reclamation projects are changing the ecology of hypersaline lake staging areas, which could have a potentially negative affect on phalaropes (Colwell and Jehl, 1994; Jehl, 1994). The main reason for the loss of habitat on breeding grounds has been hypothesized to be the conversion of most of the North American prairie grasslands and associated wetlands to agriculture (tillage)(Lesterhuis and Clay, 2010). Habitat loss and/or degradation of habitat during migration has also been implicated in declines (Lesterhuis and Clay, 2010). Wilson's phalaropes are particularly susceptible to habitat loss and degradation at the few sites that hold significant molt congregations prior to the main migratory movement to wintering grounds (for example, up to 50 percent of the population is believed to congregate at the Great Salt Lake, Utah). Extraction of water for agricultural use and the degradation of water quality at these sites are of particular concern. The majority of the population is believed to winter in the saline lakes of the altiplano in Argentina, Bolivia, and Peru, where mining activities are affecting the quality of water and the extent of saline lagoons. Large concentrations of phalaropes also are known to winter in saline lakes on the Argentinean Pampas and the Central Chaco (Argentina and Paraguay), where ever-expanding agriculture and increasing severity of drought are significant threats.

In Minnesota, a possible reason for declines in Wilson's phalaropes was postulated to be fire suppression (Hanowski and others, 1999). Fire suppression increased the shrub vegetation and subsequently decreased open grass/sedge areas in wetland ecosystems that phalaropes require for nesting.

\section{Climate Change}

The species could be particularly vulnerable to the effects of climate change on its breeding habitat (Lesterhuis and Clay, 2010). Parts of the prairies are predicted to become drier, and drought has already been documented as main reasons for abandonment of breeding areas. On the other hand, other areas of prairie are predicted to become wetter; however, it is uncertain whether these areas will provide suitable nesting habitat for the species. The future availability of water in saline lakes and Southern Cone lowlands in the nonbreeding areas is also a cause for concern. For example, it has been shown that drought at Mar Chiquita, a large saline lagoon in Argentina, negatively affects the number of Wilson's phalaropes.

\section{Management}

\section{Response to Management}

Wilson's phalaropes nest in idle, hayed, and grazed grasslands adjacent to wetlands (Hohn, 1967, Kantrud and Higgins, 1992). Management of grassland can create essential upland habitat for breeding shorebirds, including Wilson's phalaropes, through grazing, mowing, or prescribed burning. Before European settlement, breeding shorebirds specialized in exploiting the grassland mosaics created by bison herbivory and fires (Eldridge, 1992). Prescribed burning can improve nesting habitat for all shorebirds (Eldridge, 1992). 
In North Dakota, Wilson's phalaropes nested at higher densities in hayland mowed the previous year than in grazed areas (Kantrud, 1981). Idle grasslands and previously grazed areas provided habitat for nesting, but areas with cattle present during the breeding season were less suitable (Renken, 1983; Renken and Dinsmore, 1987; Kantrud and Higgins, 1992). In Alberta, Wilson's phalaropes were present in deferred-grazed (grazed after 15 July) native pasture (Prescott and others, 1993). Nesting occurred in areas that were moderately grazed in Nebraska (Faanes and Lingle, 1995) and heavily grazed in Saskatchewan (Colwell, 1987). Although Wilson's phalaropes occasionally nested in cropland (smallgrain stubble) in North Dakota (Higgins, 1975), native grassland was preferred over cropland and tame grassland in southern Canada and the northern United States (Owens and Myres, 1973; Eldridge 1992; Kantrud and Higgins, 1992). In the northern Great Plains, Wilson's phalaropes favor Conservation Reserve Program (CRP) grassland blocks $>100$ ha in size (D. H. Johnson, unpublished data). Johnson and Schwartz (1993) reported that Wilson's Phalaropes were present in low numbers in CRP fields in the northern Great Plains (North Dakota, South Dakota, and eastern Montana). In Saskatchewan aspen parkland, Wilson's phalaropes were observed in dense nesting cover that contained wetlands (Prescott and others, 1993; 1995).

Tillage agriculture is expanding into western prairie landscapes and the effects of this land-use change on habitats used by nongame wetland birds are unknown (May and others, 2002). From 19992000, May and others (2002) surveyed 196 stock ponds within grassland (>95 percent grass) and cropland ( $>75$ percent tillage) landscapes to evaluate effects of land use on nongame wetland bird densities in western South Dakota. Abundance of Wilson's phalaropes was greater in grassland study areas where cattle grazing limited growth of thick-stemmed emergent vegetation and reduced the overall vegetative cover in stock ponds.

In Montana, instances of Wilson's phalaropes fatally colliding with a power transmission line were reported (Malcolm, 1982). Highest mortalities occurred in August and September during fall migration period. The power transmission line structure was constructed over a wetland that was intermittently flooded. The structure consisted of steel towers that supported six pairs of 25-mm diameter conductor wires in two layers below two static or lightning interceptor wires of 14-mm diameter. Distances from the water to the conductor wires ranged from 14 to $33 \mathrm{~m}$.

\section{Recommendations}

Several specific management actions and considerations pertinent to Wilson's phalaropes were suggested by Dechant and others (2002):

- Protect wetland complexes with both seasonal and semipermanent wetlands to provide suitable habitat during both wet and dry years (Kantrud and Stewart, 1984; Colwell and Oring, 1988c). Wilson's phalaropes exhibit annual variation in nest site selection, moving to deeper, more permanent wetlands in dry years (Hohn, 1967; Colwell 1991).

- Ensure the presence of wet-meadow areas near deeper wetlands during the breeding season (Colwell and Oring, 1988c). This may make it easier for adults to move young from nests to wetlands by decreasing overland travel distance. Wilson's phalaropes nest in upland vegetation early in the breeding season and wet-meadow vegetation later in the season (Colwell and Oring, 1990).

- Prevent diversion of water from saline lakes and wetlands in western staging areas (Colwell and Jehl, 1994). Preserve and/or restore wetlands (Johnson, 1996).

- Consider shorebird needs when creating impoundments for waterfowl; provide nesting islands and beaches with gentle inclines (Colwell and Oring, 1988c). Wilson's phalaropes in 
Alberta, Saskatchewan, and North Dakota nested on islands or in wet-meadow zones around lakes and wetlands (Bent, 1962; Hohn, 1967; Kagarise 1979).

- Do not disturb (for example, drain, mow, burn, or heavily graze) nesting habitat during the breeding season, which generally extends from early May to late July (Kantrud and Higgins, 1992).

- Use prescribed burning to improve nesting habitat (Eldridge, 1992).

- Defer livestock grazing (after 15 July) in pastures that contain wetlands important to breeding Wilson's phalaropes (Prescott and others, 1993). Idle grasslands and previously grazed areas provide habitat for nesting, but areas with cattle present during the breeding season are less suitable (Renken, 1983; Renken and Dinsmore, 1987; Kantrud and Higgins, 1992). In Alberta, Wilson's phalaropes were present in deferred-grazed (grazed after 15 July) native pasture (Prescott and others, 1993).

- Do not construct power lines through or within $1 \mathrm{~km}$ of known historical high-water marks of wetlands or dry basins known to hold water intermittently (Malcolm, 1982). Avoid constructing power lines through flight lines or heavily used waterbird migration routes.

A conservation plan for Wilson's phalarope was prepared in 2010 (Lesterhius and Clay, 2010). Many of the conservation strategies they suggested were broad and not specific to local areas. A few of their general recommendations included ensuring quality of wetland habitats on breeding grounds, and maximizing recruitment into the population by minimizing breeding failure (as a result of nest predation and abandonment to disturbance). Lesterhius and Clay (2010) pointed out the lack of information about the species during its migration outside of North America and on the South American nonbreeding (wintering) grounds. Other important areas of research they noted were the need to (a) quantify the exposure to and the likely impacts of agrochemicals, heavy metals, and other contaminants on phalaropes; (b) determine the extent to which agricultural land uses alter the ecology of wetland breeding and migration habitats; (c) determine methods for reducing/eliminating nest predation; (d) investigate the impact of the introduction of exotic species (for example, exotic fish species, cheatgrass); and (e) develop and refine models to explore the likely effects of climate change on breeding and nonbreeding habitats (Lesterhius and Clay, 2010).

\section{Research Priorities}

Wilson's phalaropes have been relatively well-studied on their breeding grounds and at several staging sites in North America (Lesterhaus and Clay, 2010). Therefore, research priorities found in the literature focused on the following: (a) how to better understand the use of saline lakes in the altiplano of Argentina, Bolivia, Chile, and Peru; (b) how to quantify the importance of wintering areas and habitats away from the altiplano saline lakes; and, (c) identification of the habitats used and flyways followed during the northbound migration (Lesterhaus and Clay, 2010). However, the U.S. Shorebird Conservation Plan research priorities listed for avocets in the previous section could also apply to breeding Wilson’s phalaropes in North America (Oring and others, 2000).

\section{Bibliography}

Andrei, A.E., Smith, L.M., Haukos, D.A., and Surles, J.G., 2006, Community composition and migration chronology of shorebirds using the saline lakes of the Southern Great Plains, USA: Journal of Field Ornithology, v. 77, p. 372-383.

Andrei, A.E., Smith, L.M., Haukos, D.A., Johnson, W.P., 2007, Behavior of migrant shorebirds in saline lakes of the Southern Great Plains: Waterbirds, v. 30, p. 326-334. 
Andrei, A.E., Smith, L.M., Haukos, D.A., Surles, J.G., and Johnson, W.P., 2009, Foraging ecology of migrant shorebirds in saline lakes of the southern Great Plains: Waterbirds, v. 32, p. 138-148.

Ashley, M.C., Robinson, J.A., Oring, L.W., and Vinyard, G.A., 2000, Dipteran standing stock biomass and effects on aquatic bird predation at a constructed wetland: Wetlands, v. 20, p. 84-90.

Austin, J.E., and Pyle, W.H., 2004, Nesting ecology of waterbirds at Grays Lake, Idaho: Western North American Naturalist, v. 64, p. 277-292.

Baldassarre, G.A., and Fischer, D.H., 1984, Food habits of fall migrant shorebirds on the Texas high plains: Journal of Field Ornithology, v. 55, p. 220-229.

Benning, W.E., 1974, Phalaropes hawking insects over the water at Montezuma: Kingbird, v. 21, p.11. Bent, A.C., 1962, Life histories of North American shorebirds, Part 1: Dover Publications, Inc., New York, New York, 602 pp.

Bomberger, M.L., 1984, Quantitative assessment of the nesting habitat of Wilson's Phalarope: Wilson Bulletin, v. 98, p. 473-475.

Brown, S., Hickey, C., Harrington, B., and Gill, R., eds., 2001, The United States Shorebird Conservation Plan, $2^{\text {nd }}$ edition: Manomet Center for Conservation Sciences, Manomet, Massachusetts.

Burger, J., and Howe, M., 1975, Notes on winter feeding behavior and molt in Wilson's phalaropes: Auk, v. 92, p. 442-451.

Colwell, M.A., 1986a, The first documented case of polyandry for Wilson's phalarope (Phalaropus tricolor): Auk, v. 103, p. 611-612.

Colwell, M.A., 1986b, Intraspecific brood parasitism in three species of prairie-breeding shorebirds: Wilson Bulletin, v. 98, p. 473-475.

Colwell, M.A., 1987, Breeding biology, intrasexual competition, and philopatry in Wilson's phalarope (Phalaropus tricolor): Unpublished PhD Thesis, University of North Dakota, Grand Forks, North Dakota.

Colwell, M.A., 1991, Effects of fluctuating wetland conditions on prairie shorebirds: Pp. 173-180 in Holroyd, G.L, Burns, G., and Smith, H.C., eds., Proceedings of the second endangered species and prairie conservation workshop, Prov. Mus. Alberta, Edmonton, Alberta.

Colwell, M.A., 1992, Wilson phalarope nest success is not influenced by vegetation concealment: Condor, v. 94, p. 767-772.

Colwell, M.A., and Jehl, J.R., Jr., 1994, Wilson’s phalarope (Phalaropus tricolor): The Birds of North America Online (Poole, A., editor), Ithaca, Cornell Lab of Ornithology; Retrieved from the Birds of North America Online: http://bna.birds.cornell.edu/bna/species/083. Accessed 20 April 2011.

Colwell, M.A., and Oring, L.W., 1988a, Breeding biology of Wilson’s phalarope in southcentral Saskatchewan: Wilson Bulletin, v. 100, p. 567-582.

Colwell, M.A., and Oring, L.W., 1988b, Habitat use by breeding and migrating shorebirds in southcentral Saskatchewan: Wilson Bulletin, v. 100, p.554-566.

Colwell, M.A., and Oring, L.W., 1988c, Variable female mating tactics in a sex-role reversed shorebird, Wilson’s Phalarope (Phalaropus tricolor): National Geographic Research, v. 4, p. 408-415.

Colwell, M.A., and Oring, L.W., 1988d, Sex ratios and intrasexual competition for mates in a sex-role reversed shorebird, Wilson's phalarope (Phalaropus tricolor): Behavioral Ecology and Sociobiology, v. 22, p. 165-173.

Colwell, M.A., and Oring, L.W., 1988e, Wing fluttering and intrasexual competition for mates in a sexrole reversed shorebird, Wilson's Phalarope (Phalaropus tricolor): Behavioral Ecology and Sociobiology, v. 22, p. 165-173.

Colwell, M.A., and Oring, L.W., 1988f, Return rates of prairie shorebirds: sex and species differences: Wader Study Group Bulletin, v. 55, p. 21-24. 
Colwell, M.A., and Oring, L.W., 1990, Nest characteristics of prairie shorebirds: Canadian Journal of Zoology, v. 68, p. 297-302.

Colwell, M.A., Reynolds, J.D., Gratto, C.L., Schamel, D., and Tracy, D., 1988, Phalarope philopatry: Proceedings of the XIXth International Ornithological Congress.

Cunningham, M.A., and Johnson, D.H., 2006, Proximate and landscape factors influence grassland bird distributions: Ecological Applications, v. 16, p. 1062-1075.

Dahl, T.E., and Johnson, C.E., 1991, Status and trends of wetlands in the conterminous United States, mid-1970s to mid-1980s: U.S. Fish and Wildlife Service, Washington, D.C.

Davis, C.A., and Smith, L.M., 1998, Ecology and management of migrant shorebirds in the Playa Lakes Region of Texas: Wildlife Monographs, v. 140, p. 5-45.

Dechant, J.A., Johnson, D.H., Igl, L.D., Goldade, C.M., Zimmerman, A.L., and Euliss, B.R., 2002, Effects of management practices on grassland birds: Wilson's Phalarope: Northern Prairie Wildlife Research Center, Jamestown, North Dakota.

Delehanty, D.J., 1991, The effect of clutch size on prolactin, testosterone, and incubation persistence in male Wilson's Phalaropes, Phalaropus tricolor: Unpublished M.S. Thesis, University of North Dakota, Grand Forks, North Dakota.

Delehanty, D.J., and Oring, L.W., 1993, Effect of clutch size on incubation persistence in male Wilson's phalaropes (Phalaropus tricolor): Auk, v. 110, p. 521-528.

Delehanty, D.J., Fleischer, R.C., Colwell, M.A., and Oring, L.W., 1998, Sex-role reversal and the absence of extra-pair fertilization in Wilson's phalaropes: Animal Behaviour, v. 55, p. 995-1002.

DeWeese, L.R., Lowell, C., McEwen, L.A.S., and Deblinger, R.D., 1983, Effects on birds of fenthion aerial application for mosquito control: Journal of Economic Entomology, v. 76, p. 906-911.

Dinsmore, J.J., and Schuster, W., 1997, Wilson's phalarope nest in Boone County: Iowa Bird Life, v. 67, p. 67.

Dittman, D.L., Zink, R.M., and Gerwin, J.A., 1989, Evolutionary genetics of phalaropes: Auk, v. 106, p. 326-331.

Donaldson, G., Hyslop, C., Morrison, G., Dickson, L., and Davidson, I., 2000, Canadian shorebird conservation plan: Canadian Wildlife Service, Hull, Quebec.

Duebbert, H.F., and Kantrud, H.A., 1987, Use of no-till winter wheat by nestling ducks in North

Dakota: Journal of Soil and Water Conservation, v. 42, p. 50-53.

Einemann, L., 1991, A nesting report of a Wilson’s Phalarope in Lancaster County: Nebraska Bird Review, v. 59, p. 59-61.

Eldridge, J., 1992, Management of habitat for breeding and migrating shorebirds in the Midwest: U.S. Fish and Wildlife Service Leaflet 13.2.14, 6 pp.

Ellis, H.I., and Jehl, J.R., 1991, Total body water and body composition in phalaropes and other birds: Physiological Zoology, v. 64, p. 973-984.

Estrella, S.M., Masero, J.A., and Perez-Hurtado, A., 2007, Small-prey profitability: Field analysis of shorebirds' use of surface tension of water to transport prey: Auk, v. 124, p. 1244-1253.

Euliss, N.H., Jr., and Mushet, D.M., 1996, Water-level fluctuation in wetlands as a function of landscape condition in the prairie pothole region: Wetlands, v. 16, p. 587-593.

Faanes, C.A., and Lingle, G.R., 1995, Breeding birds of the Platte River Valley of Nebraska: Northern Prairie Wildlife Research Center home page, Jamestown, North Dakota, Online at http://www.npwrc.usgs.govindex.htm (version 02SEP99).

Fivizzani, A.J., Colwell, M.A., and Oring, L.W., 1986, Plasma steroid levels in free-living Wilson's Phalaropes, Phalaropus tricolor: Gen. Comp. Endocrinol., v. 62, p. 137-144. 
Fivizzani, A.J., Oring, L.W., El Halawani, M.E., and Schlinger, B.A., 1990, Hormonal basis of male parental care and female intrasexual competition in sex-role reversed birds: Pp. 273-286 in Wada, M., ed., Endocrinology of birds: molecular to behavioral, Springer Verlag, Berlin, Germany.

Friedmann, H., 1963, Host relations of parasitic cowbirds: U.S. National Museum Bulletin, v. 233, p. 1276.

Gammonley, J.H., and Laubhan, M.K., 2002, Patterns of food abundance for breeding waterbirds in the San Luis Valley of Colorado: Wetlands, v. 22, p. 499-508.

Gleason, R.A., and Euliss, N.H., Jr., 1996, Impact of agricultural land-use on prairie wetland ecosystems: experimental design and overview: Proceedings of the North Dakota Academy of Science, v. 50, p. 103-107.

Gochfeld, M., 1984, Antipredator behavior: aggressive and distraction displays of shorebirds: Pp. 289377 in Burger, J., and Olla, B.L., eds., Shorebirds: breeding behavior and populations: Plenum Press, New York, New York.

Grue, C.E., Tome, M.W., Messmer, T.A., Henry, D.B., Swanson, G.A., and DeWeese, L.R., 1989, Agricultural chemicals and prairie pothole wetlands: meeting the needs of the resource and the farmer-U.S. perspective: Transactions of the North American Wildlife and Natural Resources Conference, v. 54, p. 43-58.

Hanowski, J.M., Christian, D.P., and Nelson, M.C., 1999, Response of breeding birds to shearing and burning in wetland brush ecosystems: Wetlands, v. 19, p. 584-593.

Hatch, D.R.M., 1971, Brown-headed cowbird parasitism on spotted sandpiper and Wilson's phalarope: Blue Jay, v. 29, p. 17-18.

Higgins, K.F., 1975, Shorebird and game bird nests in North Dakota croplands: Wildlife Society Bulletin, v. 3, p. 176-179.

Hohn, E.O., 1967, Observations on the breeding biology of Wilson's phalarope (Steganopus tricolor) in central Alberta: Auk, v. 84, p. 220-244.

Holmes, P.F., 1939, Some oceanic records and notes on the winter distribution of phalaropes: Ibis, $v$. 51, p. 329-342.

Howe, M.A., 1972, Pair bond formation and maintenance in Wilson's Phalarope, Phalaropus tricolor: Unpublished PhD Dissertation, University of Minnesota, Minneapolis, Minnesota, 169 pp.

Howe, M.A., 1975a, Social interactions in flocks of courting Wilson’s Phalaropes (Phalaropus tricolor): Condor, v. 77, p. 24-33.

Howe, M.A., 1975b, Behavioral aspects of the pair bond in Wilson's Phalarope: Wilson Bulletin, v. 87, p. 248-270.

Hurlbert, S.H., Lopez, M., and Keith, J.O., 1984, Wilson's Phalarope in the central Andes and its interaction with the Chilean Flamingo: Revista Chilena de Historia Natural, v. 57, p. 47-57.

Jehl, J.R., 1968, Relationships in the Charadrii (shorebirds): a taxonomic study based on color patterns of the downy young: San Diego Society of Natural History, v. 18, p. 25-74.

Jehl, J.R., 1988, Biology of eared grebe and Wilson's phalarope in the nonbreeding season: a study of adaptations to saline lakes: Studies in Avian Biology, v. 12, p. 1-74.

Jehl, J.R., 1994, Changes in saline lake avifaunas in the past 150 years: Pp. 258-272 in Jehl, J.R., and Johnson, N.K., eds., A century of avifaunal change in western North America: Studies in Avian Biology, v. 15.

Jehl, J.R., 1997, Fat loads and flightlessness in Wilson's phalaropes: Condor, v. 99, p. 538-543. Jehl, J.R., 1999, Population studies of Wilson's phalaropes at fall staging areas, 1980-1997: a challenge for monitoring: Waterbirds, v. 22, p. 37-46.

Johns, J.E., 1969, Field studies of Wilson’s phalarope: Auk, v. 86, p. 660-670. 
Johnson, D.H., 1996, Management of northern prairies and wetlands for the conservation of Neotropical migratory birds: Pp. 53-67 in Thompson, F.R., ed., Management of Midwestern landscapes for the conservation of Neotropical migratory birds, U.S.D.A. Forest Service General Technical Report NC187.

Johnson, D.H., and Schwartz, M.D., 1993, The Conservation Reserve Program: habitat for grassland birds: Great Plains Research, v. 3, p. 273-295.

Kagarise, C.M., 1979, Breeding biology of the Wilson’s phalarope in North Dakota: Bird Banding, v. 50, p. 12-22.

Kantrud, H.A., 1981, Grazing intensity effects on the breeding avifauna of North Dakota native grasslands: Canadian Field-Naturalist, v. 95, p. 404-417.

Kantrud, H.A., and Higgins, K.F., 1992, Nest and nest site characteristics of some ground-nesting, nonpasserine birds of northern grasslands: Prairie Naturalist, v. 24, p. 67-84.

Kantrud, H.A., Newton, W.E., 1996, A test of vegetation-related indicators of wetland quality in the prairie pothole region: Journal of Aquatic Ecosystem Health, v. 5, p. 177-191.

Kantrud, H.A., and Stewart, R.E., 1984, Ecological distribution and crude density of breeding birds on prairie wetlands: Journal of Wildlife Management, v. 48, p. 426-437.

Koenig, D., 1984, A Wilson’s Phalarope nest in Allamakee County: Iowa Bird Live, v. 54, p. 123. Lack, D., 1968, Ecological adaptations for breeding in birds: Methuen, London, United Kingdom.

Laubhan, M.K., and Gammonley, J.H., 2000, Density and foraging habitat selection of waterbirds breeding in the San Luis Valley of Colorado: Journal of Wildlife Management, v. 64, p. 808-819.

Lesterhuis, A.J., and Clay, R.P., 2010, Conservation plan for Wilson's phalarope (Phalaropus tricolor), Version 1.1: Manomet Center for Conservation Sciences, Manomet, Massachusetts. Online at http://www.rhrap.org/sites/default/files/file/Wilsons_Phalarope_Conservation_Plan_10_0228_v1.1.pdf. Accessed 11 July 2011.

Mahoney, S.A., and Jehl, J.R., Jr., 1985, Adaptations of migratory shorebirds to highly saline and alkaline lakes: Wilsons phalarope and American avocet: Condor, v. 87, p. 520-527.

Malcolm, J.M., 1982, Bird collisions with a power transmission line and their relation to botulism at a Montana wetland: Wildlife Society Bulletin, v. 10, p. 297-304.

Martin, D.B., and Hartman, W.A., 1986, The effect of cultivation on sediment and deposition in prairie pothole wetlands: Water, Air, and Soil Pollution, v. 34, p. 45-53.

May, S.M., Naugle, D.E., Higgins, K.F., 2000, Effects of land use on nongame wetland birds in Western South Dakota stock ponds, USA: Waterbirds, v. 25, p. 51-55.

Mcalpine, D.F., Phinney, M., and Makepeace, S., 1988, New Brunswick breeding of Wilson’s Phalarope, Phalaropus tricolor, confirmed: Canadian Field-Naturalist, v. 102, p. 77-78.

Morrison, R.I.G., and Manning, T.H., 1976, First breeding records of Wilson's Phalarope for James Bay, Ontario: Auk, v. 93, p. 656-657.

Morrison, R.I.G., and Myers, J.P., 1987, Wader migration systems in the New World: Wader Study Group Bulletin, v. 49, p. 57-69.

Murray, B.G., 1983, Notes on the breeding biology of Wilson’s phalarope: Wilson Bulletin, v. 95, p. 472-475.

National Geographic Society, 1987, Field guide to the birds of North America, $2^{\text {nd }}$ edition: National Geographic Society, Washington, D.C., 464 pp.

Naugle, D.E., 1997, Habitat area requirements of prairie wetland birds in eastern South Dakota: Unpublished PhD Dissertation, South Dakota State University, Brookings, South Dakota, 85 pp.

Naugle, D.E., Higgins, K.F., and Nusser, S.M., 1999, Effects of woody vegetation on prairie wetland birds: Canadian Field-Naturalist, v. 113, p. 487-492. 
Neely, R.K., and Baker, J.L., 1989, Nitrogen and phosphorus dynamics and the fate of agricultural runoff: Pp. 92-131 in van der Valk, A.G., ed., Northern Prairie Wetlands, Iowa State University Press, Ames, Iowa.

Nelson, D.L., 1998, Wilson’s phalarope, Phalaropus tricolor: Pp. 186-187 in Kingery, H.E., ed., Colorado Breeding Bird Atlas, Colorado Bird Atlas Partnership, Copublished by Colorado Division of Wildlife, Denver, Colorado.

Nelson, E.W., 1877, A contribution to the biography of Wilson's phalarope: Bulletin of the Nuttall Ornithological Club, v. 2, p. 38-43.

O’Brien, M., Crossley, R., and Karlson, K., 2006, The shorebird guide: Houghton Mifflin Company, New York, New York.

Ogg, J.E., Ryder, R.A., and Smith, H.L., Jr., 1989, Isolation of vibrio cholera from aquatic birds in Colorado and Utah: Applied Environmental Microbiology, v. 55, p. 95-99.

Oring, L.W., and Davis, W.M., 1966, Shorebird migration at Norman, Oklahoma: 1961-1963: Wilson Bulletin, v. 78, p. 166-174.

Oring, L.W., Fivizzani, A.J., Colwell, M.A., and El Halawani, M.E., 1988, Hormonal changes associated with natural and manipulated incubation in the sex-role reversed Wilson's Phalarope: Gen. Comp. Endocrinol., v. 72, p. 247-256.

Owens, R.A., and Myres, M.T., 1973, Effects of agriculture upon populations of native passerine birds of an Alberta fescue grassland: Canadian Journal of Zoology, v. 51, p. 697-713.

Pinkowski, B.C., 1981, Further notes on Wilson's phalarope-American avocet feeding associations: Journal of Field Ornithology, v. 52, p. 147.

Renken, R.B., 1983, Breeding bird communities and bird-habitat associations on North Dakota waterfowl production areas of three habitat types: Unpublished M.S. Thesis, Iowa State University, Ames, Iowa, 90 pp.

Renken, R.B., and Dinsmore, J.J., 1987, Nongame bird communities on managed grasslands in North Dakota: Canadian Field-Naturalist, v. 101, p. 551-557.

Reynolds, J.D., Colwell, M.A., and Cooke, F., 1986, Sexual selection and spring arrival times of rednecked and Wilson's phalaropes: Behavioral Ecology and Sociobiology, v. 18, p. 303-310.

Rubega, M.A., 1997, Surface tension prey transport in shorebirds: How widespread is it?: Ibis, v. 139, p. 488-493.

Rubega, M.A., and Obst, B.S., 1993, Surface-tension feeding in phalaropes: discovery of a novel feeding mechanism: Auk, v. 110, p. 169-178.

Sauer, J.R., Hines, J.E., Fallon, J.E., Pardieck, K.L., Ziolkowski, D.J., Jr., and Link, W.A., 2011, The North American Breeding Bird Survey, Results and Analysis 1966 - 2009: Version 3.23.2011. Online at http://www.mbr-pwrc.usgs.gov/bbs/bbs.html. Accessed on 12 July 2011.

Schlinger, B.A., Fivizzani, A.J., and Callard, G.V., 1989, Aromatase, 5-alpha and 5-beta reductase in brain, pituitary and skin of the sex-role reversed Wilson's Phalarope: Journal of Endocrinology, v. 122, p. 573-581.

Schmidt, G.D., and Frantz, D.W., 1972, Helminth parasites of Wilson's Phalarope, Steganopus tricolor, 1819, in Montana and Colorado: Proc. Helm. Soc. Wash., v. 39, p. 269-270.

See, R.B., Naftz, D.L., Peterson, D.A., Crock, J.G., and Erdman, J.A., 1992, Detailed study of selenium in soil, representative plants, water, bottom sediment, and biota in the Kendrick Reclamation Project Area, Wyoming, 1988-1990: Water-Resources Investigations Report 91-4131, U.S. Geological Survey, Cheyenne, Wyoming.

Siegfried, W.R., and Batt, B.D.J., 1972, Wilson’s phalaropes forming feeding associations with shovelers: Auk, v. 89, p. 667-668. 
Skagen, S.K., and Knopf, F.L., 1992, Toward conservation of midcontinental shorebird migrations: Conservation Biology, v. 7, p. 533-541.

Sordahl, T.A., 1981, Predator mobbing in the shorebirds of North America: Wader Study Group

Bulletin, v. 31, p. 41-44.

Steeves, J.B., and Holohan, S., 1975, Wilson's phalarope nesting range extended to the St. Lawrence Valley in Quebec: Canadian Field-Naturalist, v. 89, p. 185.

Stewart, R.E., and Kantrud, H.A., 1965, Ecological studies of waterfowl populations in the prairie potholes of North Dakota: U.S. Fish and Wildlife Service, Bureau of Sport Fisheries and Wildlife, 1965 Progress Report, 14 pp.

Stewart, R.E., and Kantrud, H.A., 1972, Population estimates of breeding birds in North Dakota: Auk, v. 89, p. 766-788.

Stout, G.D., 1967, The shorebirds of North America: Viking Press, New York, New York.

Strauch, J.G., 1978, The phylogeny of the Charadriiformes (Aves): a new estimate using the method of character compatibility analysis: Transactions of the Zoological Society London, v. 34, p. 263-345.

Tymstra, Y.R., 1989, Ah, sweet sewage lagoon!: from domestic wastes an idyllic wildlife habitat: Canadian Geographic, v. 109, p. 66-72.

Unitt, P., 1984, The birds of San Diego County: San Diego Society of Natural History, San Diego, California.

U.S., Shorebird Conservation Plan, 2004, High Priority Shorebirds - 2004: Unpublished Report, U.S. Fish and Wildlife Service, Arlington, Virginia.

Viet, R., and Peterson, W., 1993, Birds of Massachusetts: Massachusetts Audubon Society, Lincoln, Massachusetts.

Weber, M.J., 1978, Non-game birds in relation to habitat variation on South Dakota wetlands: Unpublished M.S. Thesis, South Dakota State University, Brookings, South Dakota, 54 pp.

Weber, M.J., Vohs, P.A., and Flake, L.D., 1982, Use of prairie wetlands by selected bird species in South Dakota: Wilson Bulletin, v. 94, p. 550-554.

Wetmore, A., 1925, Food of American phalaropes, avocets and stilts: U.S. Department of Agriculture Bulletin No. 1359.

Williams, G.C., 1953, Wilson’s phalaropes as commensals: Condor, v. 55, p. 158. 


\section{Sora (Porzana carolina)}

\section{Introduction}

Sora (Porzana carolina) is the most abundant and widely distributed North American rail (Melvin and Gibbs, 1996). Soras breed and winter primarily in freshwater marshes dominated by emergent vegetation, but they also occur in brackish coastal marshes during migration. Soras are more often heard rather than seen and have one of the most distinctive calls of any marsh bird, a loud descending whinny call. Soras feed primarily on seeds of wetland plants and invertebrates. Wild rice is a favorite food in the late summer and fall. Although appearing

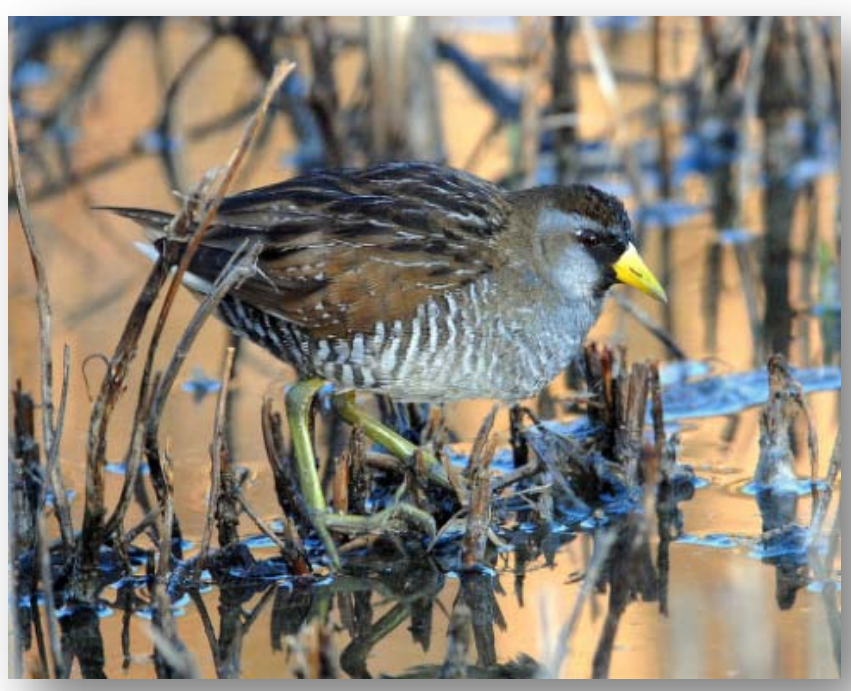

Sora, courtesy of Dave Menke, U.S. Fish and Wildlife Service. to be weak and reluctant fliers, soras migrate hundreds of kilometers each spring and fall between breeding and wintering wetlands. Many wetlands important to soras rank among the most threatened in the United States, including the coastal marshes of California, Florida, Louisiana, New Jersey, and Texas. The sora is legally hunted in 31 states and two Canadian provinces. Bag limits are generally liberal, but little information is available on harvest, population trends, or effect of harvest on populations. Key studies of the sora's breeding biology, ecology, and behavior have been conducted in the midwestern United States by Walkinshaw (1940), Pospichal and Marshall (1954), Tanner and Hendrickson (1956), and Kaufmann (1983; 1987; 1989). Some researchers report that the sora population plunged in central North America during the past 30 years, largely the result of natural loss of wetlands from a long drought from which both wetlands and rail populations may yet recover (Conway and others, 1994). Others report that sora population trends are uncertain (Melvin and Gibbs, 1994).

A simple Google search on the Internet for "Porzana carolina" revealed 108,000 results and a Google Scholar search provided 2,070 results (accessed 11 July 2011). "Sora” revealed 111,000 results through Google and 1,610 results through Google Scholar (accessed 11 July 2011).

\section{Natural History}

Morphology

The sora is a medium-sized rail (20 to $25 \mathrm{~cm}$ total length) with grayish-brown plumage, greenish legs, and long toes (Melvin and Gibbs, 1996). Adult mass averages 71.9 to $88.0 \mathrm{~g}$ and the mean mass of males is greater than that of females. Soras are the only North American rail with a combination of a stubby, yellow bill and black mask on the face and throat (Melvin and Gibbs, 1996). Adults of both sexes have similar plumage, but females have darker bills.

\section{Distribution}

Soras breed in North America in suitable wetland habitat. The northern limits of their breeding range include north-central British Columbia (Campbell and others, 1990), northern Saskatchewan (Smith, 1996), northern Manitoba, northern Ontario, south-central Quebec, extreme southern 
Newfoundland (Godfrey, 1986), New Brunswick, Prince Edward Island, and Nova Scotia (Erskine, 1992). Soras also breed in southeastern Alaska (Kessel and Gibson, 1978; Armstrong, 1995), extreme northwestern British Columbia (Campbell and others, 1990), and southwestern Northwest Territories (Godfrey, 1986). They may be more likely to breed near the northern edge of their range in Alaska and Canada during years when drought conditions exist in more southern breeding areas (Trapp and others, 1981). The southern limit of the breeding range for soras includes southern Pennsylvania (Brauning, 1992), southcentral Ohio (Peterjohn, 1989), southcentral Indiana, central Illinois, central Iowa, central Nebraska, eastern Colorado (Andrews and Righter, 1992), eastern and southern New Mexico (Hubbard, 1978), central and northwest Arizona, and southern Nevada. Soras also breed in central Kansas (Parmelee and others, 1970; Tacha, 1975; Zimmerman, 1984; Thompson and Ely, 1989), northeastern West Virginia (Buckelew and Hall, 1994), and northwestern Virginia (Melvin and Gibbs, 1996). The western limit of the breeding range includes western California east of the Sierra from Mono County south to Inyo County, northeastern California (Small, 1994), Oregon and Washington mainly east of the Cascades (Gilligan and others, 1994), and central British Columbia (Campbell and others, 1990), northwestern Washington, around San Francisco Bay, and in the Central Valley of California.

Soras winter from the Atlantic Coastal Plain, throughout Florida, west along the Gulf Coast to coastal and southwestern Texas, southern New Mexico, southern and western Arizona, extreme southeastern Nevada and extreme southwestern Utah, and south throughout Mexico and Central America, the Caribbean, to northern South America (Melvin and Gibbs, 1996). Soras also winter along the Pacific Coast of North America. Most soras winter in areas that have a minimum January temperature above $-1^{\circ} \mathrm{C}$ (Root, 1988). Wintering populations extend into colder areas along the Colorado River in Arizona and along the Rio Grande in Colorado, where discharges of hot water from power plants may create open-water conditions. The densest wintering populations in the United States are in southern Florida, the bayous of southern Louisiana, the coastal plain of Texas, and the lower Colorado River valley in southwestern Arizona (Root, 1988).

Soras stay in Colorado from early April through early October (Griese and others, 1980). A few soras remain in Colorado in winter, but most winter from the southern edge of the United States to South America. The Breeding Bird Atlas Colorado (1998) reported soras breeding throughout the state where suitable wetlands were available.

\section{Migration}

Little is known about migration behavior and patterns for the sora. Because this species is reclusive and difficult to observe, migrants are not easily detected (Melvin and Gibbs, 1996). They are a regular spring and fall migrant between their wintering and breeding areas. They are presumed to be nocturnal migrants (Stoddard and Norris, 1967; Avery and others, 1976; Robbins, 1991). It is unknown whether some populations are resident where breeding and winter ranges overlap. Vocalizations are useful in locating migrants during the springtime, but in other seasons, soras are much less vocal so they are more difficult detect (Melvin and Gibbs, 1996). Timing of migration, especially in the fall, may be determined in part by timing of frosts (Bent, 1926; Walkinshaw, 1940; Tanner and Hendrickson, 1956). In some areas of their range, soras appear to move from smaller breeding wetlands to congregate in larger wetlands with abundant food in August and early September (Pospichal and Marshall, 1954). Earliest spring migrants arrive in Colorado in early April (Griese and others, 1980).

Haramis and Kearns (2007) conducted banding and telemetry studies of fall migrant soras in the historical rail hunting and exceptional stopover habitat of the Wild Rice marshes of the tidal Patuxent River. Their radio-telemetry results depicted soras as long-distance migrants with high stopover survival and a critical dependence on tidal freshwater marshes for migratory fattening. Their stopover period was 
frequently $>40$ days and the mean mass gain of +0.6 g per day suggested that soras accumulate large fat reserves for long-distance flight. Further radio-tracking confirmed that soras are strong flyers with a demonstrated overnight (10 hour) flight range of 700-900+ km. They could conceivably fly nonstop from the Patuxent River to Florida, the Bahamas, or even the Caribbean (Haramis and Kearns, 2007).

Habitat

The Breeding Bird Atlas Colorado (1998) reported soras breeding in a variety of wetlands in Colorado, including cattail marshes, grass or sedge marshes, wet meadows, and irrigated hayfields especially in mountain parks (Pantle, 1998). Soras prefer cattails with shallow water for breeding and escape, and 80 percent of Atlas reports came from marshes, with cattails usually the dominant vegetation. Atlasers reported much less use of other habitats, such as hay meadows, open water, willow cars, lowland riparian thickets, and salt meadows.

Across their breeding range, soras primarily use wetlands with shallow and intermediate water depths, dominated by robust or fine-leaved emergent vegetation, especially cattails (Typha spp.), sedges (Carex spp., Cyperus spp.), burreeds (Sparganium spp.), and bulrushes (Scirpus spp.) (Walkinshaw, 1940, Pospichal and Marshall, 1954; Tanner and Hendrickson, 1956; Griese and others, 1980; Johnson and Dinsmore, 1985; 1986a; Gibbs and Melvin, 1990; Gibbs and others, 1991; Crowley, 1994). Soras may use wetland edges and upland fields, including row crops, adjacent to wetlands during broodrearing or postbreeding dispersal (Porspichal and Marshall, 1954; Johnson and Dinsmore, 1985). They may also occasionally nest in brackish or salt marshes along the Atlantic Coast, in habitat dominated by smooth cordgrass (Spartina alterniflora) or common reed (Phragmites communis) (Greenlaw and Miller, 1982).

Soras breeding in prairie potholes in North Dakota and Iowa occur almost exclusively in wetlands classified as seasonal or semipermanent (Kantrud and Stewart, 1984; Johnson and Dinsmore, 1986a). In northwestern Iowa, breeders seem to use emergent vegetation types in proportion to availability (Johnson and Dinsmore, 1985; 1986a). The highest breeding densities are in relatively shallow, shoreward portions of wetlands where water level instability produces diverse mosaics of fine and robust emergent vegetation. This habitat preference may be related to an increased prevalence of wetland plant seeds, especially sedges, which are important foods during the breeding season. High densities of floating and submerged residual vegetation may increase habitat quality by providing a substrate for invertebrates near the water surface and accessible to soras, which have short bills (Melvin and Gibbs, 1996).

In Iowa, mean water depth in 71 sora breeding territories was $38.4 \mathrm{~cm} \pm 16.1$ standard deviation (SD)(range 0-92) and was not significantly different from that for the Virginia rail (Rallus limicola) (Johnson and Dinsmore, 1986a). Mean vegetation height was $128.0 \mathrm{~cm} \pm 42.5 \mathrm{SD}$, and mean number of stems $/ \mathrm{m}^{2}$ in territories was $121.9 \mathrm{~cm} \pm 80.9 \mathrm{SD}$. Soras did not use areas where heavy snow, ice, and high water had flattened emergent vegetation until early May, when new sedge growth was $20-30 \mathrm{~cm}$ in height and 80-100 stems $/ \mathrm{m}^{2}$ provided some cover.

In central Minnesota, sora nesting densities increase with increasing abundance of cattails (Pospichal and Marshall, 1954). In eastern Alberta, where cattails are rare, Carex sedges form predominant nesting habitat, and breeding densities are no greater where cattails do occur (Lowther, 1977). In British Columbia, soras nest in wetter habitats and more often in cattails than Virginia rails (Campbell and others, 1990). Soras breeding in Massachusetts are present in wetlands with larger areas of cattails and greater interspersion of vegetation and water compared to wetlands where they are absent or where Virginia rails are present (Crowley, 1994). However, Johnson and Dinsmore (1986a) found no clear differences in breeding-habitat use between these two species in Iowa. Wetlands used by breeding 
soras in Maine had more fine-leaved and robust emergent and aquatic-bed vegetation (Cowardin and others, 1979) and fewer ericaceous shrubs than did wetlands where soras were not present (Gibbs and Melvin, 1990). Nests of soras in western New York were located in $\geq 70$ percent emergent vegetation with a mean water depth of 24-56 cm and an average vegetation height that ranged from 69-133 cm (Lor and Malecki, 2006).

Breeding soras appear to be area-independent in their selection of wetlands (Melvin and Gibbs, 1996). Soras in Wisconsin may breed in wetlands with only a few hectares of shallow water and emergent vegetation (Robbins, 1991), and as small as $<0.5$ ha in Massachusetts (Crowley, 1994). In Iowa, soras occurred in 17 percent of wetlands $<1$ ha (Brown and Dinsmore, 1986). In one Maine study, soras occurred in 8 percent of wetlands $<1$ ha (Gibbs and others, 1991), but in another study, soras were absent from wetlands $<5$ ha but occurred in 39 percent of wetlands $>5$ ha (Gibbs and Melvin, 1990). In Massachusetts, soras occurred on 8 percent of wetlands 0.5-2.0 ha, compared to 22-42 percent of wetlands $>2$ ha (Crowley, 1994). Soras, however, may be more area-sensitive than Virginia rails. They occurred less frequently than Virginia rails on wetlands $<5$ ha in Iowa and Massachusetts (Brown and Dinsmore, 1986; Crowley, 1994) and in 1 of 2 Maine studies (Gibbs and Melvin, 1990; Gibbs and others, 1991).

During migration, soras stop and rest in freshwater emergent wetlands and frequently in brackish or salt marshes. Stands of wild (Zizannia spp.) and cultivated (Oryza sativa) rice and flooded annual grasses or forbs provide important feeding habitats for migrants (Walkinshaw, 1940; Meanley, 1960; Odom, 1977; Fannucchi and others, 1986; James and Neal, 1986). Soras seem to prefer wetland sites that offer both tall, dense cover and shorter seed-producing plants (Meanley, 1965; Andrews, 1973; Griese and others, 1980; Rundle and Fredrickson, 1981; Sayre and Rundle, 1984). Migrants sometimes appear away from wetlands, including upland fields, pastures, gardens, and lawns, and, probably unintentionally, on roads, airport runways, and sandy beaches (Peterjohn, 1989; Campbell and others, 1990; Amos, 1991).

Little is known about habitat use by soras on their winter range, but habitats used include freshwater, brackish, and salt marshes (Eddleman and others, 1988; Small, 1994). Soras are probably the most abundant in marshes with good interspersion of shallow water and emergent vegetation (Gochfeld, 1972; Conway, 1990), but are also found in winter in vegetated canals and ditches, rice fields, impoundments, mangroves, wet pastures, overgrown and cultivated fields, and emergent vegetation along edges of small ponds and rivers (Gochfeld, 1972; Raffaele, 1989; Stiles and Skutch, 1989; Amos, 1991; Rosenberg and others, 1991; Howell and Webb, 1995). At the northern fringes of their winter range, soras may use wetlands kept free of ice by sewer outlets, freshwater springs, or hotwater discharges from power plants (Root, 1988; Veit and Petersen, 1993).

\section{Foraging Habits}

The main foods eaten by soras are the seeds of wetland plants and aquatic invertebrates (Melvin and Gibbs, 1996). Proportion of invertebrates in their diet increases in the spring (Martin and others, 1951; Rundle and Sayre, 1983). Common plant foods include seeds of wild or cultivated rice, smartweeds, sedges, bulrushes, and grasses (Martin and others, 1951; Pospichal and Marshall, 1954; Rundle and Sayre, 1983). Principal animal foods include adults, larvae, and pupae of a variety of aquatic insects (Orders Coleoptera, Diptera, Hemiptera, Odonata) and snails (Gastropoda) (Pospichal and Marshall, 1954; Gochfeld, 1972).

The microhabitat used for foraging consists of stands of robust emergent vegetation interspersed with shorter, seed-producing vegetation, and vegetative debris that provides good substrate for invertebrates near the water surface (Meanley, 1965; Rundle and Sayre, 1983; Sayre and Rundle, 1984; 
Johnson and Dinsmore, 1986a; Melvin and Gibbs, 1994). During brood-rearing and premigration periods, soras may be attracted to shallower portions of wetlands where seed-producing plants such as sedges, bulrushes, smartweeds, beggarticks (Bidens spp.), and grasses provide food (Johnson and Dinsmore, 1986a; Manci and Rusch, 1988). In the late summer, soras may leave wetlands for short periods to feed in upland fields and row crops (Horak, 1970; Johnson and Dinsmore, 1986a). Migrating soras feed in wetlands with tall emergent vegetation, where wild or cultivated rice or flooded annual grasses and forbs are preferred feeding habitats (Walkinshaw, 1940; Meanley, 1960; Odom, 1977; Fannucchi and others, 1986). Migrants in southeastern Missouri preferred water depths of 5-15 cm, but often used deeper water, up to $46 \mathrm{~cm}$ (Sayre and Rundle, 1984). Because of their foraging behavior and omnivorous diet, soras may be able to forage in a wider range of water depths than Virginia rails, which seem to occur more frequently at sites with shallow water ( $<15 \mathrm{~cm}$ deep) or saturated soils (Sayre and Rundle, 1984).

Soras search for food by raking floating vegetation with their feet or pulling aside vegetation with their bill and visually searching for food (Kaufmann, 1989). They use their short, chickenlike bill to peck from substrates or water surfaces. Soras generally feed from a standing position. In autumn, soras strip seed heads of maturing smartweeds and annual grasses (Meanley, 1965; Rundle and Sayre, 1983). They occasionally feed by swimming in open water like a coot (Pospichal and Marshall, 1954).

Parents feed invertebrates to the chicks for 2-3 weeks (Kaufmann, 1989), although Pospichal and Marshall (1954) believed that the chicks were able to forage independently when only a week old. Chicks are precocial, follow adults, begging for food, and are fed by adults. They gradually develop the ability to eat food items placed in front of them, then capture their own food, and increase their consumption of plant material (Kaufmann, 1989).

\section{Breeding}

In Colorado, soras lay their eggs from late May through early July. They have small territories. Six pairs of soras (and 10-18 pairs of Virginia rails) nested in a 10-ha marsh near Fort Collins, with only $10 \mathrm{~m}$ separating the closest sora nests (Glahn, 1974). Soras lay a substantial 8-12 eggs; the black downy young leave the nest almost immediately upon hatching - as soon as their down dries (Pantle, 1998). Soras carefully conceal their nests, and Colorado Breeding Bird Atlasers based most confirmations of breeding on observations of fledglings.

\section{Demography \& Population Status}

There is no information on annual survival or mean life span for soras (Melvin and Gibbs, 1996). Survival probability during the breeding season (August through April) of 23 radiomarked soras in southwestern Arizona was only $0.308 \pm 0.256 \mathrm{SE}$ for all age and sex classes combined (Conway and others, 1994). This survival probability may have been lowered by the effects of the radio transmitters or underestimated because of emigration from the study area. Causes of mortality include predation, exposure, shooting and trapping, and collision with towers (Melvin and Gibbs, 1996). Pospichal and Marshall (1954) reported predation to be the primary cause of egg loss, although actual cases of predation were never observed. Confirmed or strongly suspected egg predators include marsh wrens (Cistothorus palustris; Allen, 1934), common grackle (Quiscalus quiscula), common crow (Corvus brachyrhinchos), striped skunk (Mephitus mephitis), coyote (Canis latrans; Lowther, 1977), and raccoon (Procyon lotor; Tanner and Hendrickson, 1956). Porspichal and Marshall (1954) reported 2 clutches of soras crushed by muskrats (Ondatra zibethicus) that used nests as feeding platforms. Lowther (1977) reported 2 nests trampled by cattle after water under the nests had dried. Confirmed predators on adult or juvenile soras include coyote (Lowther, 1977), bobcat (Felis rufus; James and 
Neal, 1986), feral house cats (F. silvestrus; Porspichal and Marshall, 1954), northern harriers (Circus cyaneus), Cooper's hawk (Accipiter cooperii; Craighead and Craighead, 1969), red-shouldered hawk (Buteo lineatus; Bent, 1937), peregrine falcon (Falco peregrinus; Barber and Barber, 1983), barn owl (Tyto alba; Bent, 1938; French and Wharton, 1975), great horned owl (Bubo virginianus; Errington and others, 1940), and short-eared owl (Asio flammeus; Bent, 1938).

Although soras are considered the most abundant rail in North America (Melvin and Gibbs, 1994), population size has not been estimated. Local density estimates of breeding soras include 0.1 birds/ha in 1,321 wetlands in central North Dakota (Kantrud and Stewart, 1984), 1.3 birds/ha at Horicon Marsh in southern Wisconsin (Manci and Rusch, 1988), 1.6 birds/ha in 28 wetlands in northwestern Iowa (Tanner and Hendrickson, 1956), and 0.6 pairs/ha at Fossil Creek Reservoir in northern Colorado (Glahn, 1974). Breeding Bird Survey (BBS) estimates that populations of soras have declined 3.3 percent \pm 1.7 SD annually from 1966-1991 in North America $(p<0.05, n=528$ BBS routes; Conway and others, 1994). Populations were stable 1982-1991 ( $p>0.10, n=149$ BBS routes) in Canada, but declined 8.5 percent \pm 2.1 SD annually in the United States during the same period $(p<0.01, n=241$ BBS routes) (Conway and others, 1994). Declines were most severe in central North America, where wetland loss has been the greatest (Tiner, 1984; Dahl, 1990; Dahl and Johnson, 1991). The Breeding Bird Survey regional trend analysis for soras along 30 Colorado routes from 1966 to 1999 showed a positive trend estimate of 0.5 (-2.8, 4.8; 95 percent CI) (Sauer and others, 2011). From 1999 to 2009, the trend was also positive and estimated to be 0.3 (-6.6, 8.4; 95 percent CI). However, the regional credibility measure for this species was in the "red" category, meaning that data have an important deficiency because there were overall low abundances of soras per route and/or the results were too imprecise to detect long-term trends.

\section{Threats}

\section{Shooting and Trapping}

Soras are legally hunted in 31 states and in Manitoba and Ontario, and bag limits are liberal in most states (25 birds/day in 27 states; Melvin and Gibbs, 1994). From 1964 through 1976, an estimated 13,400-47,200 soras were harvested annually by waterfowl hunters, and an equal number were estimated to have been shot by nonwaterfowl hunters (Martin, 1979). Only 14 states report recent estimates of numbers of sora hunters or harvest, and 9 of these lumped harvest estimates of soras with other rails (Melvin and Gibbs, 1994). Five states estimated harvests of >2,000 soras: Florida, Iowa, Louisiana, New Jersey, and Virginia. The effects of annual harvest on sora populations are unknown. Although low hunter interest and the difficulty of hunting rails probably keeps annual kill within sustainable levels, effects of incidental take by waterfowl hunters and other bird hunters on local or regional populations are unknown (Eddleman and others, 1988; Melvin and Gibbs, 1994). Much larger numbers were harvested early in the $20^{\text {th }}$ century. Bent (1926) reported that hunters commonly shot 100150 rails/day along the Connecticut River in Connecticut, and estimated 1,000 rails killed at Longmeadow, Massachusetts, in 1908. Sora hunting is an old tradition in coastal marshes of Connecticut, New Jersey, Maryland, and Virginia, but numbers of both birds and hunters have declined substantially (Ripley, 1977). Fur trapping has also been known to cause accidental mortality of soras and other rails (Meanley, 1969; Linscomb, 1976; Eddleman and others, 1988).

\section{Other Potential Threats}

There are no data for the effects of pesticides and other contaminants on soras (Melvin and Gibbs, 1996), but they may be a threat to soras in southern commercial rice fields and in wetlands in 
California and Arizona (Eddleman and others, 1988). Soras are potentially susceptible to mortality from ingested lead shot, which was present in the gizzards of 7.4-12.3 percent of soras collected in Maryland and 1.8 percent of birds from Missouri (Artmann and Martin, 1975; Stendell and others, 1980). Migrating soras are commonly killed at tall, lighted towers (Stoddard and Norris, 1967; Avery and others, 1976; Robbins, 1991) and probably in collisions with overhead wires (Sibley, 1993). At a TV tower in northern Florida, Stoddard and Norris (1967) found soras killed in all months except June, July, and August, and in greater numbers than other rails.

In southcentral Colorado, decreasing water levels reduced suitable habitat by 95 percent in July and early August 1975 and 1976. Irrigation practices contributed to midsummer drying of wetlands and caused premature dispersal of rails to concentrate in wetlands with more water (Griese and others, 1980). Porspichal and Marshall (1954) attributed an incident of nest abandonment to human disturbance. Harvesting of wild rice may disturb or reduce food available to local or migrant soras (Fannucchi and others, 1986). Porspichal and Marshall (1954) also reported no significant difference in mortality rates of marked and unmarked juvenile soras. Conway and others (1994) speculated that depredation of 3 of 26 radiomarked soras within 4 days of capture was the result of radiomarking, and that the low estimated survival probability during nonbreeding season may have reflected increased mortality of radiomarked individuals.

Sora behavior changes in response to human disturbance. Burger and Gochfeld (1998) studied the effects of ecotourists on bird behavior at the Loxahatchee National Wildlife Refuge in Florida. They observed birds before people were near, while people were present, and following the departure of people. The variation in feeding behavior was largely explained by whether people were present, the number of people present, and the amount of noise made by people. Time devoted to feeding and number of strikes or pecks decreased while people were present. The percentage of time spent foraging and the number of strikes decreased as the noise by people increased (Burger and Gochfeld, 1998).

\section{Management}

\section{Response to Management}

Mowing can be used to create more interspersion of habitats, which has been shown to be beneficial for marsh birds, including soras (Rehm and Baldassare, 2007). There is some general agreement that marshes that undergo cyclic vegetation changes (resulting from varying water levels) show maximum avian use and production during the period when emergent macrophytes and open water are present in equal proportions in an interspersed pattern (Weller and Spatcher, 1965; Weller and Fredrickson, 1974). One way to create interspersion of habitats is by mowing, which increases habitat edges. An increase in edge density was shown to be the best predictor of abundance of soras, and other marsh birds, in two marsh locations in NewYork (Rehm and Baldassare, 2007).

Coastal wetlands in the Gulf Coast Chenier Plain are commonly managed intensively by fall or winter burning and constructing impoundments to improve winter habitat for waterbirds, reduce wetland loss, and create emergent wetlands (Gabrey and others, 2001). Gabrey and others (2001) conducted experimental burns in 4 types of impounded and unimpounded marshes on the Rockefeller State Wildlife Area in southwestern Louisiana. They found that vegetation characteristics in burned marshes did not differ from those of unburned marshes by the first summer post-burn, and that winter burning did not affect bird species richness or species composition. Bird surveys, including those for soras, showed no difference between burned and unburned marshes during the first or third summers postburn, but were on average 2 times greater in burned than in unburned marshes during the second summer post-burn (Gabrey and others, 2001). Controlled burning of marshes has also been used 
successfully to prevent woody invasion (Zimmerman, 1984). In a radio-telemetry study of soras at the USFWS Texas Mid-coast National Wildlife Refuge Complex, there was no direct mortality from prescribed burns (Grace and others, 2005). For the cases in which birds were tracked for the longest period, their ability to survive fire was documented. One sora was found alive under a clump of burned gulf cordgrass. The authors suggested that the rails that were unable to escape fire managed to survive by burying themselves underneath dead, damp vegetation. They also believed that the presence of standing water could aid in the survival of rails during prescribed burns. They suggested that managers conducting winter prescribed burns in this particular area should burn early in the winter when water is still present (Grace and others, 2005).

Conway and others (2010) evaluated whether prescribed fire could be used as a surrogate disturbance event to help restore historical flooding conditions along the lower Colorado River basin for the benefit of Yuma Clapper rails and four sympatric marsh-dependent birds, including soras. They conducted call-broadcast surveys for marsh birds within burned and unburned (control) plots both preand post-burn and found that fire increased the number of Yuma Clapper rails and Virginia rails, but did not affect the numbers of black rails, soras, and least bitterns. They concluded that prescribed fire could be used to set back succession of emergent marshlands and help mimic the natural disturbance regime in the lower Colorado River basin (Conway and others, 2010).

In Iowa, several studies have found that soras do not use restored wetland basins with any high degree of frequency (Delphey and Dinsmore, 1993; VanRees-Siewert, 1993; Schreiber, 1994). However, Schuster (1998) studied restored and natural wetlands and avifaunal use in the Prairie Pothole region of northern Iowa and found that both Virginia rails and soras used both wetland types equally. In the Columbia River Basin of eastern Washington, densities of soras were greater on unaltered wetlands than on wetlands that had been excavated to create openings for dabbling and diving ducks (Creighton and others, 1997).

Linz and others (1997) studied the effects of herbicide-induced changes in wetland vegetation (largely cattails, Typha spp.) on densities of soras in northeastern North Dakota. In 1990 and 1991, 17 cattail-dominated wetlands were randomly assigned to 0 percent (reference wetlands), 50 percent, 70 percent, or 90 percent spray coverages with glyphosate-based herbicide. They found that one year posttreatment, reference wetlands harbored more soras than did the treated wetlands but sora numbers were similar among treatments two years post-treatment. They concluded that sora populations using semipermanent wetlands may be negatively influenced by fragmenting stands of dense cattails.

Timmermans and others (2008) examined the associations between breeding marsh bird abundances and Great Lakes hydrology. From 1995-2002, Lakes Erie and Huron-Michigan experienced water-level declines. Abundance of soras declined within the marshes of these lakes during the same period. They concluded that long-term changes and annual water-level fluctuations are important abiotic factors affecting the abundance of some marsh-dependent birds in Great Lakes coastal marshes.

\section{Recommendations}

Melvin and Gibbs (1994) summarized the management needs of soras. Most important is preservation of emergent wetlands that provide breeding, migration, and wintering habitats. Many wetland types most important to soras remain among the most threatened in the United States, including coastal marshes of California, Florida, Louisiana, New Jersey, and Texas, palustrine emergent wetlands in south Fordia and Prairie Pothole Region, and western riparian wetlands. Soras would benefit from policies and management that eliminate or minimize the effects of wetland draining and filling; siltation, eutrophication, and other forms of pollution; and invasion by exotic plants. 
Wetland habitat management to benefit soras should encourage diverse stands of both fineleaved and robust emergent vegetation, including sedges, bulrushes, and especially cattails, as well as moist-soil annuals around edges of wetlands (Rundle and Sayre, 1983; Johnson and Dinsmore, 1986). Periodic gradual drawdowns that encourage horizontal zonation of wetland vegetation may maximize habitat quality. Management should maximize interspersion of emergent vegetation and open water areas (Weller and Spatcher, 1965), because soras seem most abundant near edges of cover types or vegetation and open water (Walkinshaw, 1940; Porspichal and Marshall, 1954; Johnson and Dinsmore, 1986; Crowley, 1994; Rehm and Baldassare, 2007). Wetland impoundments constructed with irregular or sloping bottoms will provide greater diversity of water levels and topography and will increase vegetation-water edge (Eddleman and others, 1988). Impoundments drawn down during the summer can be flooded in the late summer to provide habitat for post-breeding and migrant soras (Rundle and Fredrickson, 1981). When spring rail use is desired, impoundments with annual grasses and smartweeds should be de-watered over winter to protect vegetation from ice damage and waterfowl and to encourage growth of perennial vegetation.

\section{Research Priorities}

Research needs and priorities for soras were summarized by Melvin and Gibbs (1994):

- Develop reliable techniques for monitoring population trends. Indices of population trends using playback recording surveys will require identifying periods of peak response to tape-recorded calls, and obtaining better distributional information on breeding soras to allow stratification of surveys within states and provinces.

- Develop a reliable harvest survey in the United States and Canada.

- Determine the effects of habitat quality, predation, weather, and water-level fluctuations on reproductive success and breeding densities of soras.

- Describe habitat use and distribution patterns of wintering soras. Determine management actions necessary to maximize carrying-capacity of winter habitats.

- Describe chronology, habitat use, and behavior of soras during postbreeding dispersal and migration. Priority should be given to unstudied populations outside the Midwestern United States.

- Characterize site fidelity, annual survivorship, life span, and age of first breeding.

\section{Bibliography}

Allen, A.A., 1934, The Virginia rail and the sora: Bird Lore, v. 36, p. 196-204.

Allen, T., Finkbeiner, S.L., and Johnson, D.H., 2004, Comparison of detection rates of breeding marsh birds in passive and playback surveys at Lacreek National Wildlife Refuge, South Dakota:

Waterbirds, v. 27, p. 277-281.

Amos, E.J.R., 1991, A guide to the birds of Bermuda: E.J.R. Amos, Warwick, Bermuda.

Andrews, D.A., 1973, Habitat utilization by sora, Virginia rails, and king rails near southwestern Lake Erie: Unpublished Master’s Thesis, Ohio State University, Columbus.

Andrews, R., and Righter, R., 1992, Colorado birds: a reference to their distribution and habitat: Denver Museum of Natural History, Denver, Colorado.

Armstrong, R.H., 1995, Guide to the birds of Alaska: Alaska Northwest Books, Seattle, Washington. Artmann, J.W., and Martin, E.M., 1975, Incidence of ingested lead shot in sora rails: Journal of Wildlife Management, v. 39, p. 514-519. 
Avery, M., Springer, P.F., and Cassel, J.F., 1976, Effects of a tall tower on nocturnal bird migration-a portable ceilometer study: Auk, v. 93, p. 281-291.

Barber, J.C., and Barber, M.M., 1983, Prey of an urban Peregrine Falcon: Maryland Bird Life, v. 39, p. 108-110.

Bent, A.C., 1926, Life histories of North American marsh birds: U.S. National Museum Bulletin 135.

Bent, A.C., 1937, Life histories of North American birds of prey, Pt. 1, U.S. National Museum Bulletin 167.

Bent, A.C., 1938, Life histories of North American birds of prey, Pt. 2, U.S. National Museum Bulletin 170.

Berger, A.J., 1951, Nesting density of Virginia and sora rails in Michigan: Condor, v. 53, p. 202.

Billard, R.S., 1948, An ecological study of the Virginia rail (Rallus limicola) and the sora (Porzana carolina) in some Connecticut swamps: Unpublished M.S. Thesis, Iowa State College, Ames, Iowa.

Brauning, D.W., 1992, Atlas of breeding birds in Pennsylvania: University of Pittsburgh Press, Pittsburgh, Pennsylvania.

Brewster, W., 1902, Voices of a New England marsh: Bird-Lore, v. 4, p. 43-56.

Brown, M., and Dinsmore, J.J., 1986, Implications of marsh size and isolation for marsh bird management: Journal of Wildlife Management, v. 50, p. 392-397.

Buckelew, A.R., Jr., and Hall, G.A., 1994, The West Virginia breeding bird atlas: University of Pittsburgh Press, Pittsburgh, Pennsylvania.

Burger, J., and Gochfeld, M., 1998, Effects of ecotourists on bird behavior at Loxahatchee National Wildlife Refuge, Florida: Environmental Conservation, v. 25, p. 13-21.

Burger, J., and Howe, M., 1975, Notes on winter feeding behavior and molt in Wilson's phalaropes: Auk, v. 92, p. 442-451.

Campbell, R.W., Dawe, N.K., McTaggart-Cowan, I., Cooper, J.M., Kaiser, G.W., and McNall, M.C.E., 1990, The birds of British Columbia, Vol. 2: Royal British Columbia Museum, Victoria.

Conway, C.J., 1990, Seasonal changes in movements and habitat use by three sympatric species of rails: Unpublished M.S. Thesis, University of Wyoming, Laramie, Wyoming.

Conway, C.J., Eddleman, W.R., and Anderson, S.H., 1994, Nesting success and survival of Virginia rails and soras: Wilson Bulletin, v. 106, p. 466-473.

Conway, C.J., and Eddleman, W.R., 1994, Virginia rail: Pp. 192-207 in Tacha, T.C., and Braun, C.E., eds., Migratory shore and upland game bird management in North America, International Association of Fish and Wildlife Agencies, Washington, D.C.

Conway, C.J., Nadeau, C.P., and Piest, L., 2010, Fire helps restore natural disturbance regime to benefit rare and endangered marsh birds endemic to the Colorado River: Ecological Applications, v. 20, p. 2024-2035.

Craighead, J.J., and Craighead, F.C., Jr., 1956, Hawks, owls, and wildlife: Dover Publications, Inc., New York, New York.

Creighton, J.H., Sayler, R.D., Tabor, J.E., and Monda, M.J., 1997, Effects of wetland excavation on avian communities in eastern Washington: Wetlands, v. 17, p. 216-227.

Crowley, S.K., 1994, Habitat use and population monitoring of secretive waterbirds in Massachusetts: Unpublished M.S. Thesis, University of Massachusetts, Amherst, Massachusetts.

Dahl, T.E., 1990, Wetland losses in the United States 1780s to 1980s: U.S. Department of the Interior, Fish and Wildlife Service, Washington, D.C.

Dahl, T.E., and Johnson, C.E., 1991, Status and trends of wetlands in the conterminous United States, mid-1970s to mid-1980s: U.S. Department of the Interior, Fish and Wildlife Service, Washington, D.C. 
Dickerman, R.W., 1971, Notes on various rails in Mexico: Wilson Bulletin, v. 83, p. 49-56.

Eddleman, W.R., Knopf, F.L., Meanley, B., Reid, F.A., and Zembal, R., 1988, Conservation of North American rallids: Wilson Bulletin, v. 100, p. 458-475.

Errington, P.L., Hamerstrom, F., and Hamerstrom, F.N., Jr., 1940, The Great Horned Owl and its prey in north-central United States: Agricultural Exp. Stn., Res. Bull., 277, Iowa State College, Ames, Iowa.

Erskine, A.J., 1992, Atlas of breeding birds of the Maritime Provinces: Nimbus Publications and Nova Scotia Museum, Halifax.

Erwin, R.M., Conway, C.J., and Hadden, S.W., 2002, Species occurrence of marsh birds at Cape Cod National Seashore, Massachusetts: Northeastern Naturalist, v. 9, p. 1-12.

Fannucchi, W.A., Fannucchi, G.T., and Nauman, L.E., 1986, Effects of harvesting wild rice, Zizania aquatica, on soras, Porzana carolina: Canadian Field-Naturalist, v. 100, p. 533-536.

French, T.W., and Wharton, C.H., 1975, Barn owls as mammal collectors in Georgia, Alabama, and South Carolina: Oriole, v. 40, p. 6-10.

Gabrey, S.W., Afton, A.D., and Wilson, B.C., 2001, Effects of structural marsh management and winter burning on plant and bird communities during summer in the Gulf Coast Chenier Plain: Wildlife Society Bulletin, v. 29, p. 218-231.

Gibbs, J.P., and Melvin, S.M., 1990, An assessment of wading birds and other avifauna and their habitats in Maine: Unpublished final report, Maine Department of Inland Fisheries and Wildlife, Bangor.

Gibbs, J.P., and Melvin, S.M., 1993, Call-response surveys for monitoring breeding populations of grebes, bitterns, and rails: Journal of Wildlife Management, v. 57, p. 27-34.

Gibbs, J.P., Longcore, J.R., McAuley, D.G., and Ringelman, J.K., 1991, Use of wetland habitats by selected nongame waterbirds in Maine: U.S. Fish and Wildlife Service Resource Publication No. 9.

Gilligan, J., Smith, M., Rogers, D., and Contreras, A., 1994, Birds of Oregon: status and distribution: Cinclus Publications, McMinnville, Oregon.

Glahn, J.F., 1974, Study of breeding rails with recorded calls in north-central Colorado: Wilson Bulletin, v. 86, p. 206-214.

Gochfeld, M., 1972, Observations on the status, ecology, and behavior of soras wintering in Trinidad, West Indies: Wilson Bulletin, v. 84, p. 200-201.

Godfrey, W.E., 1986, The birds of Canada: National Museum of Natural Sciences, Ottawa.

Grace, J.B., Allain, L.K., Baldwin, H.Q., Billock, A.G., Eddleman, W.R., Given, A.M., Jeske, C.W., and Moss, R., 2005, Effects of prescribed fire in the coastal prairies of Texas: U.S. Geological Survey Open-File Report, 2005-1287.

Greenlaw, J.S., and Miller, R.F., 1982, Breeding soras on a Long Island salt marsh: Kingbird, v. 32, p. 78-84.

Greenlaw, J.S., and Miller, R.F., 1983, Calculating incubation periods of species that sometimes neglect their last eggs: the case of the sora: Wilson Bulletin, v. 95, p. 459-461.

Griese, H.J., Ryder, R.A., and Braun, C.E., 1980, Spatial and temporal distribution of rails in Colorado: Wilson Bulletin, v. 92, p. 96-102.

Haramis, B.M., and Kearns, G.D., 2007, Soras in tidal marsh: banding and telemetry studies on the Patuxent River, Maryland: Waterbirds, v. 30, p. 105-121.

Horak, G.J., 1970, A comparative study of the foods of the sora and Virginia rail: Wilson Bulletin, v. 82, p. 207-213.

Horstman, A.J., Nawrot, J.R., and Woolf, A., 1998, Mine-associated wetlands as avian habitat: Wetlands, v. 18, p. 298-304. 
Howell, S.N.G., and Webb, S., 1995, A guide to the birds of Mexico and northern Central America: Oxford University Press, New York, New York.

Hubbard, J.P., 1978, Revised check-list of the birds of New Mexico: New Mexico Ornithological Society Publication no. 6.

James, D.A., and Neal, J.C., 1986, Arkansas birds: their distribution and abundance: University of Arkansas Press, Fayetteville, Arkansas.

Johnson, R.R., and Dinsmore, J.J., 1985, Brood-rearing and postbreeding habitat use by Virginia rails and soras: Wilson Bulletin, v. 97, p. 551-554.

Johnson, R.R., and Dinsmore, J.J., 1986a, Habitat use by breeding Virginia rails and soras: Journal of Wildlife Management, v. 50, p. 387-392.

Johnson, R.R., and Dinsmore, J.J., 1986b, The use of tape-recorded calls to count Virginia rails and soras: Wilson Bulletin, v. 98, p. 303-306.

Kantrud, H.A., and Stewart, R.E., 1984, Ecological distribution and crude density of breeding birds on prairie wetlands: Journal of Wildlife Management, v. 48, p. 426-437.

Kaufmann, G.W., 1971, Behavior and ecology of the sora (Porzana aquatica) and Virginia rail (Rallus limicola): Unpublished PhD Dissertation, University of Minnesota, Minneapolis, Minnesota.

Kaufmann, G.W., 1977, Breeding requirements of the Virginia rail and the sora in captivity: Avic. Mag., v. 83, p. 135-141.

Kaufmann, G.W., 1983, Displays and vocalizations of the sora and the Virginia rail: Wilson Bulletin, v. 95, p. 42-59.

Kaufmann, G.W., 1987, Growth and development of sora and Virginia rail chicks: Wilson Bulletin, v. 99, p. 432-440.

Kaufmann, G.W., 1989, Breeding ecology of the Sora Porzana carolina, and the Virginia rail, Rallis limicola: Canadian Field-Naturalist, v. 3, p. 270-282.

Kearns, G.D., Kwartin, N.B., Brinker, D.F., and Haramis, G.M., 1998, Digital playback and improved trap design enhances capture of migrant soras and Virginia rails: Journal of Field Ornithology, v. 69, p. 466-473.

Kessle, B., and Gibson, D.D., 1978, Status and distribution of Alaska birds: Studies in Avian Biology, v.1.

Linz, G.M., Bergman, D.L., Blixt, D.C., and McMurl, C., 1997, Response of American coots and soras to herbicide-induced vegetation changes in wetlands: Journal of Field Ornithology, v. 68, p. 450-457.

Lor, S., and Malecki, R.A., 2006, Breeding ecology and nesting habitat associations of five marsh bird species in western New York: Waterbirds, v. 29, p. 427-436.

Lowther, J.K., 1977, Nesting biology of the sora at Vermillion, Alberta: Canadian Field-Naturalist, v. 91, p. 63-67.

Manci, K.M., and Rusch, D.H., 1988, Indices to distribution and abundance of some inconspicuous waterbirds on Horicon Marsh: Journal of Field Ornithology, v. 59, p. 67-75.

Martin, E.M., 1979, Hunting and harvest trends for migratory game birds other than waterfowl: 196476: U.S. Fish and Wildlife Service Special Scientific Report Wildlife no. 218.

Marx, D.E., Hejl, S.J., and Herring, G., 2008, Wintering grassland bird habitat selection following summer prescribed fire in a Texas gulf coast tallgrass prairie: Fire Ecology, v. 4, p. 46-62.

Mayfield, H., 1961, Nesting success calculated from exposure: Wilson Bulletin, v. 73, p. 255-261. Mayfield, H., 1975, Suggestions for calculating nest success: Wilson Bulletin, v. 87, p. 456-466.

Meanley, B., 1960, Fall food of the sora rail in the Arkansas rice fields: Journal of Wildlife Management, v. 24, p. 339. 
Meanley, B., 1965, Early-fall food and habitat of the sora in Patuxent River marshes, Maryland: Chesapeake Science, v. 6, p. 235-237.

Meanley, B., 1969, Natural history of the king rail: North American Fauna, no. 67.

Melvin, S.M., and Gibbs, J.P., 1996, Sora (Porzana carolina): American Ornithologists’ Union, Washington, D.C.

Melvin, S.M., and Gibbs, J.P., 1994, Sora, Pp. 209-217 in Tacha, T.C., and Braun, C.E., eds., Migratory shore and upland game bird management in North America: International Association of Fish and Wildlife Agencies, Washington, D.C.

Melvin, S.M., and Gibbs, J.P., 1996, Sora (Porzana carolina): Poole, A., ed., The Birds of North America Online, Ithaca, Cornell Lab of Ornithology, Retrieved from the Birds of North America Online: http://bna.birds.cornell.edu/bna/species/250. Accessed 29 June 2011.

Meyer, R., 2006, Porzana carolina: In: Fire Effects Information System, [Online], U.S. Department of Agriculture, Forest Service, Rocky Mountain Research Station, Fire Sciences Laboratory (Producer). Available online http://www.fs.fed.us/database/feis/. Accessed 10 June 2011.

Miller, R.F., 1928, Virginia rail lays in sora’s nest: Oologist, v. 45, p. 132.

Neimuth, N.D., and Solberg, J.W., 2003, Response of waterbirds to number of wetlands in the Prairie Pothole Region of North Dakota, U.S.A.: Waterbirds, v. 26, p. 233-238.

Odom, R.R., 1977, Sora: Pp. 57-65 in Sanderson, G.C., ed., Management of migratory shore and upland game birds in North America, International Association of Fish and Wildlife Agencies, Washington, D.C.

Pantle, D., 1998, Sora, Porzana carolina: Pp. 158-159 in Kingery, H.E., ed., Colorado Breeding Bird Atlas, Colorado Bird Atlas Partnership, Copublished by Colorado Division of Wildlife, Denver, Colorado.

Parmalee, D.F., Schwilling, M.D., and Stephens, H.A., 1970, Gruiform birds of Cheyenne Bottoms: Kansas Ornithological Society Bulletin, v. 21, p. 25-27.

Peterjohn, B.G., 1989, The birds of Ohio: Indiana University Press, Bloomington, Indiana.

Pospichal, L.B., and Marshall, W., 1954, A field study of sora rail and Virginia rail in central Minnesota: Flicker, v. 26, p. 2-32.

Raffaele, H.A., 1989, A guide to the birds of Puerto Rico and the Virgin Islands: Princeton University Press, Princeton, New Jersey.

Rehm, E.M., and Baldassarre, G.A., 2007, The influence of interspersion on marsh bird abundance in New York: Wilson Journal of Ornithology, v. 119, p. 648-654.

Ripley, S.D., 1977, Rails of the world: David R. Godine, Publishers, Boston, Massachusetts.

Root, T., 1988, Atlas of wintering North American birds: an analysis of Christmas count data: University of Chicago Press, Chicago, Illinois.

Rosenberg, K.V., Ohmart, R.D., Hunter, W.C., and Anderson, B.W., 1991, Birds of the lower Colorado River valley: University of Arizona Press, Tucson, Arizona.

Rundle, W.D., and Frederickson, L.H., 1981, Managing seasonally flooded impoundments for migrant rails and shorebirds: Wildlife Society Bulletin, v. 9, p. 80-87.

Rundle, W.D., and Sayre, M.W., 1983, Feeding ecology of migrant soras in southeastern Missouri: Journal of Wildlife Management, v. 47, p. 1153-1159.

Sauer, J.R., Hines, J.E., Fallon, J.E., Pardieck, K.L., Ziolkowski, D.J., Jr., and Link, W.A., 2011, The North American Breeding Bird Survey, Results and Analysis 1966 - 2009: Version 3.23.2011. Online at http://www.mbr-pwrc.usgs.gov/bbs/bbs.html. Accessed on 12 July 2011.

Sayre, M.W., and Rundle, W.D., 1984, Comparisons of habitat use by migrant soras and Virginia rails: Journal of Wildlife Management, v. 48, p. 599-605. 
Schuster, J.E., 1998, Avian community composition and diversity in natural and restored central Iowa wetlands: Unpublished M.S. Thesis, Iowa State University, City, Iowa.

Small, A., 1994, California birds: their status and distribution: Ibis Publishing Company, Vista, California.

Smith, A.R., 1996, Atlas of Saskatchewan birds: Saskatchewan Natural History Society Special Publication, no. 22.

Sorenson, M.D., 1995, Evidence of conspecific nest parasitism and egg discrimination in the sora: Condor, v. 97, p. 819-821.

Stendell, R.C., Artmann, J.W., and Martin, E., 1980, Lead residues in sora rails from Maryland: Journal of Wildlife Management, v. 44, p. 525-527.

Stiles, F.G., and Skutch, A.F., 1989, A guide to the birds of Costa Rica: Cornell University Press, Ithaca, New York.

Stoddard, H.L., and Norris, R.A., 1967, Bird casualties at a Leon County, Florida TV tower: an elevenyear study: Bulletin Tall Timbers Research Station, no. 8.

Tacha, R.W., 1975, A survey of rail populations in Kansas, with emphasis on Cheyenne Bottoms: Unpublished M.S. Thesis, Fort Hays Kansas State University, Fort Hays, Kansas.

Tanner, W.D., and Hendrickson, G.O., 1956, Ecology of the sora in Clay County, Iowa: Iowa Bird Life, v. 26, p. 78-81.

Thompson, M.C., and Ely, C., 1989, Birds of Kansas, Vol. 1: University of Kansas Museum of Natural History, Lawrence, Kansas.

Timmermans, S.T., Badzinski, S.S., and Ingram, J.W., 2008, Associations between breeding marsh bird abundances and Great Lakes hydrology: Journal of Great Lakes Research, v. 34, p. 351-364.

Tiner, R.W., Jr., 1984, Wetlands of the United States: current status and recent trends: National Wetlands Inventory, U.S. Government Printing Office, Washington, D.C.

Tozer, D.C., Nole, E., and Abraham, K.F., 2010, Effects of local and landscape-scale habitat variables on abundance and reproductive success of wetland birds: Wetlands Ecology and Management, v. 18, p. 679-693.

Trapp, J.L., Robus, M.A., Tans, G.J., and Tans, M.M., 1981, First breeding record of the sora and American coot in Alaska, with comments on drought displacement: American Birds, v. 35, p. 901902.

Veit, R., and Petersen, W., 1993, Birds of Massachusetts: Massachusetts Audubon Society, Lincoln, Massachusetts.

Walkinshaw, L.H., 1940, Summer life of the sora rail: Auk, v. 57, p. 153-168.

Webster, C.G., 1964, Fall foods of soras from two habitats in Connecticut: Journal of Wildlife Management, v. 28, p. 163-165.

Weller, M.W., and Fredrickson, L.H., 1974, Avian ecology of a managed glacial marsh: Living Bird, v. 12, p. 269-291.

Weller, M.W., and Spatcher, C.E., 1965, Role of habitat in the distribution and abundance of marsh birds: Iowa Agricultural and Home Economics Experimental Station Special Report no. 43.

Whited, D., Galatowitsch, S., Tester, J.R., Schik, K., Lehtinen, R., and Husveth, J., 2000, The importance of local and regional factors predicting effective conservation planning strategies for wetland bird communities in agricultural and urban landscapes: Landscape and Urban Planning, v. 49, p. 39-65.

Zimmerman, J.L., 1984, Distribution, habitat, and status of the sora and Virginia rail in interior Kansas: Journal of Field Ornithology, v. 55, p. 38-47. 


\section{White-faced Ibis (Plegadis chihi)}

\section{Introduction}

The white-faced ibis (Plegadis chihi) is a longlegged wader with a long, decurved bill and metallic bronze plumage. During the breeding season, adults have distinctive white feathers along the edge of their bare facial skin. The species is common, nesting in marshes in the western United States, and wintering in large flocks in Mexico, western Louisiana, and eastern Texas (Ryder and Manry, 1994). The species inhabits primarily freshwater wetlands, especially cattail (Typha spp.) and bulrush (Scirpus spp.) marshes, although it feeds in flooded hay meadows, agricultural fields, and estuarine wetlands. No subspecies of this ibis are recognized, although the more cosmopolitan glossy ibis (Plegadis falcinellus) is considered by some to be conspecific, and the two species have produced hybrids in captivity. In Louisiana, Alabama, and possibly eastern Texas, however, the two forms nest in the same colonies, apparently without interbreeding.

A simple Google search on the Internet for "Plegadis chihi" revealed 94,700 results and a Google Scholar search provided 1,080 results (accessed 11 July 2011). "White-faced ibis” revealed 324,000 results through Google and 2,170 results through Google Scholar (accessed 11 July 2011).

\section{Natural History}

\section{Distribution}

The white-faced ibis breeds in northern California, eastern Oregon, southern Idaho, southern Alberta, Montana, eastern North and South Dakota, Washington, and recently in northwestern Iowa south to Durango and Jalisco states in Mexico (Ryder and Manry, 1994; Tweit and Flores, 2006). White-faced ibises were found attempting to nest in Washington in 2001 (Tweit and Flores, 2006). The first record of nesting in Arizona occurred in 2000 at Cibola National Wildlife Refuge. The Mexican breeding distribution is poorly known. The largest breeding colonies are usually in Utah, Nevada, Oregon, and coastal Texas and Louisiana. Ibises winter primarily in coastal Louisiana and Texas south to the Mexican states of Guerrero, Puebla, and Tabasco (band recoveries), occasionally Guatemala (Land, 1970) and Costa Rica (Stiles and Skutch, 1989). Ibises also winter at Los Banos and the Salton Sea, California, other parts of southern California, and in the lower Colorado River Valley in Arizona (Rosenberg and others, 1991).

Ibises are "boom" or "bust" species as breeding populations vary considerably from year to year depending on water levels in favored marshes (Ryder, 1967). In 1949, at least 12 pairs nested at Russell Lakes in the San Luis Valley (SLV) (Ryder, 1950); however, in 1965 only 10 pairs bred in the whole SLV (Ryder, 1967). During the Colorado Breeding Bird Atlas survey, an estimated 355 pairs nested on Alamosa NWR, and more than 470 pairs were documented in the SLV during 1993 (Rilling and Falzone-Schrim, 1993). 


\section{Migration}

Ibises are highly mobile, especially in the northern hemisphere. Northernmost populations undertake regular north-south migrations; Texas and Louisiana nesters are mainly resident year-round. All populations show some postbreeding wandering. They are well adapted to find new nesting areas when regular sites become dry in droughts or are drained by humans (Ryder, 1967). Most band recoveries of birds banded as nestlings in Utah (205 of 222) have been in Mexico during the nonbreeding season: 55 in Michoacan, 45 in Jalisco, 28 in Nayarit, 24 each in Guanajuato and Sinaloa, and 29 in 9 other states. Only 1 of 16 band recoveries from Texas bandings has been in Mexico. Most recoveries of birds banded in Oregon (5 of 7), Idaho (15 of 17), and Nevada (13 of 16) have occurred in Mexico during winter. Two of 4 recoveries of Colorado bandings have been from Mexico. Some east to west movements are also suggested by 2 recoveries of Utah birds in California and one recovery of a Nevada bird in California (Ryder and Manry, 1994).

Most birds arrive at Utah and Idaho breeding areas in April and leave in September or October. A few stragglers linger in Utah as late as December (Ryder, 1967; Behle and Perry, 1975; Taylor and others, 1989). In Oregon, ibises begin migrating from Malheur National Wildlife Refuge (NWR) in early August and most have left by late September (Littlefield, 1990). Oregon birds return as early as 9 April, but average spring arrival date is 3 May. The Colorado River Valley appears to be an important migration route between Great Basin nesting areas and Mexican wintering grounds (Ryder, 1967).

During the Colorado Breeding Bird Atlas surveys (1998) (Ryder, 1998), migrant ibises were reported from all 28 latilongs of the state, but occur most often on the eastern plains and western plateaus. Most ibises leave Colorado in September, some as late as October. Based on band recoveries, most ibises from Colorado winter in Texas and Mexico (Ryder, 1993; 1994).

Habitat

General habitats where ibises can be found regardless of region and season are shallow marshes, ponds, mudflats, and swamps (Ryder and Manry, 1994). Ibises prefer, almost exclusively, areas with emergent vegetation of some type. They inhabit primarily freshwater wetlands and marshes, especially those containing cattail (Typha spp.) and bulrush (Scirpus spp.) (Ryder and Manry, 1994), but they can inhabit estuarine wetlands and coastal areas as well. Ibises usually nest in emergent vegetation or low trees and shrubs over shallow water, but can also nest on the ground on small islands. Ibises need some degree of isolation by marshes or small islands for both nesting colonies and social night roosts (Trost, 1989). At two locations in Utah, all nests were in hardstem bulrush (Kaneko, 1972) or alkali bulrush (Kotter, 1970). A nest's height, above the water or ground, may vary depending upon substrate type or other conditions. In one Utah colony, nests ranged from 99.0-202.2 cm above water that was $61 \mathrm{~cm}$ deep (Kaneko, 1972).

The white-faced ibis feeds in flooded hay meadows, agricultural fields, and wetlands (for example, pond and reservoir margins, mudflats, and marshes) with short, emergent vegetation (Ryder and Manry, 1994). Dominant plant species in foraging areas generally are sedges (Carex spp.), spikerushes (Eleocharis spp.), salt-tolerant grassworts (Salicornia spp.), saltgrass (Distichlus stricta), and greasewood (Sarcobatus vermiculatus) (Ryder and Manry, 1994). In Nevada, Colorado, Utah, Idaho, California, and Oregon irrigated crops of alfalfa, barley, and hay are important feeding sites for ibises. In Nevada, white-faced ibises feed in recently flooded agricultural fields where vegetation is $<5$ to $90 \mathrm{~cm}$ high (Bray, 1986), and they show a strong preference for alfalfa fields. Strong preferences were also found for large ( $>30 \mathrm{ha}$ ), level ( $<5$ percent slope) fields with clay or clay-loam soils and pools of standing water (Ryder and Manry, 1994). Laubhan and Gammonley (2000) speculated that differences in food abundance, vegetation structure and composition, and behavioral strategies during 
the breeding season, all influenced the ibis’ selection of foraging habitats in the SLV of Colorado. Along the Louisiana coast, flooded rice fields and livestock pastures over salt marshes are also used as feeding sites. In Wyoming, white-faced ibises have been noted in marshes, wet meadows, and along vegetated shorelines (Dorn and Dorn, 1999). Shallow marshes with emergent vegetation, lakes with vegetated shorelines, and mudflats are preferred habitat, and these areas are often surrounded by sagebrush-grassland or saltbush communities (Merrill and others, 1996). Foraging sites usually consist of shallow wetlands, agricultural fields, and shorelines of ponds and lakes (Ritter and Cerovski, 1990).

Suitable summer or breeding habitat for the white-faced ibis includes shallow marshes with “islands" of emergent vegetation, spoil banks of lakes created by dredging, and locally flooded shoals and mangrove swamps (Ryder and Manry, 1994). Ibises generally nest in wetlands on "islands" of emergent vegetation that are either flooded or that extend over the water (Ryder and Manry, 1994). However, they can also nest inland in various vegetation types as well. Most inland nesting sites in the Colorado Plateau Province consist of sagebrush (Artemisia spp.) and saltbush (Atriplex spp.)(Bailey, 1978). In the Great Basin, most nesting sites consist of hardstem bulrush (Scirpus acutus), Olney's bulrush (S. olneyi), and alkali bulrush (S. paludosus). In Colorado, Baltic rush, sedge, Carex spp., and other wetland grasses and forbs are important (Dark-Smiley and Keinath, 2003). In California, saltcedar (Tamarix spp.) and Baltic rush (Juncus balticus) are primarily used (Ivey and Severson, 1984). At the Klamath River Basin in Oregon, Taft and others (2000) observed that white-faced ibis rely on early successional emergent plants such as hardstem bulrush for nesting.

Habitat used by white-faced ibises during migration is similar to that used during the breeding season, and includes irrigated fields and mudflats along rivers and around lakes and isolated reservoirs (Taylor and others, 1989). In Oklahoma, they have been reported using a variety of habitats, from wooded streams to mudflats, and grassy fields bordering playas (Baumgartner and Baumgartner, 1992). In California, they have been found using sewage aeration ponds (Locatelli and Blankenship, 1973), and in Nebraska they have been documented in sandhill ponds and marshes (Ducey, 1988).

Area requirements for individual ibises are not known for certain and no studies of what wetland complex size best supports successful, persistent colonies have been reported (Dark-Smiley and Keinath, 2003). Ibises typically defend an area of about one meter around the nest (Belknap, 1957; Kotter, 1970), and they may defend landing and preening perches up to three meters away from their nests (Belknap, 1957). Kotter (1970) noted that in Utah no specific spatial relationships were required for ibis nests. In large colonies, most nests are densely concentrated at the center and become more isolated at the periphery (Kotter, 1970; Kaneko, 1972). At a Utah colony in alkali bulrush, distances between ibis nests ranged from 0.5 to $10 \mathrm{~m}$ and averaged about $2 \mathrm{~m}$ in areas with the highest nest density (Kotter, 1970). In Carson Lake, Nevada, a 25 ha colony in hardstem bulrush averaged 75-150 nests/ha (Herron and others, 1987), and in the SLV, Colorado, ibis nests in hardstem bulrush and cattails averaged $8 \mathrm{~m}$ from the nearest conspecific ( $n=43$; Schreur, 1987). Frederick and Ogden (1997) stated that large white ibis colonies (>1,000 pairs) need $800 \mathrm{~km}^{2}$ or more of wetlands to flourish, and proposed that larger wetlands probably tend to sustain colonies for longer periods of time. Little is known about ibis' home ranges outside the breeding season, but during the nesting period in Nevada, most birds foraged 3 to $6 \mathrm{~km}$ (but up to $18 \mathrm{~km}$ ) from their breeding colony (Bray, 1986). In late summer, prior to fall migration, breeding adults and recently fledged young have been reported ranging from 40-48 km from colonies in Idaho (Trost, 1989). No studies have reported how foraging radius might be affected by breeding colony size or density.

Earnst and others (1998) suggested that white-faced ibis would benefit from a landscape mosaic of “well-distributed peripheral wetlands and persistent colony sites.” Laubhan and Gammonley (2000) believed that hydrology is the single most important factor influencing ecosystem processes in wetlands, 
as well as habitat suitability for the white-faced ibis. The landscape mosaic must consist of wetlands that have new vegetation growth and that contain suitable water levels (approximately $1 \mathrm{~m}$ in the SLV, Colorado) from late April through the end of July (Dark-Smiley and Keinath, 2003) to sustain ibises through the breeding season. In 2003, Monte Vista NWR experienced its driest year since 1906, and although some ibises were nesting late in May, they had deserted the site by the middle of June due to several factors, including the lack of new bulrush growth and low water levels (Dark-Smiley and Keinath, 2003).

The availability of feeding areas within 15-25 km of breeding colonies is a very important landscape feature for the white-faced ibis (Dark-Smiley and Keinath, 2003). The importance of foraging areas was demonstrated in the summer of 2003 at the Monte Vista NWR in Colorado, where nesting colonies were deserted in the middle of the breeding season. It is believed that the primary reason for abandonment and low reproduction on the Refuge was the minimal or lack of shallow-water, wet meadows where ibises forage.

Frederick and Ogden (1997) determined the longevity of white-faced ibis colonies based on nesting data from Frederick and others (1996). Their results showed that large colonies of white ibis ( $>1,000$ pairs) persisted for one to 17 years and maintained at least 1,000 pairs during this time. They concluded that there may be a relationship between the size of a wetland and the longevity of ibis colonies. The colonies of greatest longevity that persisted up to 15 years, were associated with relatively large wetlands (100 to $150 \mathrm{~km}$ in dimension), and colonies that existed for only 10 years or less were associated with smaller wetlands (less than $10 \mathrm{~km}^{2}$ in dimension) (Frederick and Ogden, 1997). This same study also reported that large, new ibis colonies are generally associated with unusually high abundances of food and exceptional breeding conditions, while abandonment of ibis colonies is associated with degraded breeding conditions and changes in water levels or water management.

\section{Food Habits}

The main foods taken by white-faced ibises are aquatic and moist-soil insects and earthworms (Ryder and Manry, 1994). Larval insects, leeches, and snails are also eaten (Petersen, 1953; Capen, 1977; Bray, 1986; Bray and Klebenow, 1988; Alcorn, 1988). In Louisiana, crayfish, small fish, frogs, snails, and bivalves are consumed (Belknap, 1957). In Idaho, chironomid larvae (midges) may be an important food item (Taylor and others, 1989). Ibises choose shallowly flooded pond margins, reservoirs, and marshes to forage. Ibises also forage on recently flooded agricultural fields where vegetation is $<5$ to $90 \mathrm{~cm}$ high (Bray, 1986; Bray and Klebenow, 1988). Ibises feed in large flocks (up to $>1,000$ ). They leave their roosting and nesting marshes in the early morning to feed primarily in flood-irrigated agricultural fields, especially alfalfa. They use standing water to wash soil from prey items, although esophagi of birds collected in Nevada contained substantial amounts of soil (Bray, 1986; Bray and Klebenow, 1988). Large flocks of ibises were observed foraging for coprophilic beetles at a poultry farm in La Paz, Baja California Sur, Mexico (Blanco and Rodriguez-Estrella, 1998).

\section{Breeding}

Most ibises nesting in Colorado favor tall emergent vegetation such as bulrushes and cattails growing as "islands" surrounded by water more than $45 \mathrm{~cm}$ deep. As early as 1872, Aiken found ibises nesting in the SLV (Sclater, 1912) and in 1993 they still nested in at least 11 colonies. Ibises usually arrive in the SLV by mid-April and nest in May, but dates may vary from year to year. Both sexes take part in nest-building. Courtship occurs mainly in nesting colonies, with some calling and bickering between rivals. Nests consist of bulrush and cattail stems and average about $1 \mathrm{~m}$ above water. Colonies may consist of fewer than 5 pairs up to 100 pairs, usually intermixed with nesting Snowy egrets, black- 
crowned night-herons, and in recent years, cattle egrets. In the SLV, incubation and hatching in 1984 extended from early June to late July, yet from early May to late July in 1985 (Schreur, 1987). Young usually fledge by late July to mid-August. The Breeding Bird Atlas for Colorado confirmed that in Colorado most ibises continue to nest in the SLV, especially in marshes around Russell Lakes, between Head and San Luis Lakes, at Adams Lake, and on Alamosa and Monte Vista NWRs. Post-atlas, in 1996, two pairs nested at Arapaho NWR in North Park.

Nest initiation seems to be synchronous with subgroups of ibis, and often in large colonies there are "subcolonies" of 20-30 nests, all of which are at a similar stage (Trost, 1989). Once nest initiation has occurred, it is very important that water levels do not drop below approximately $1 \mathrm{~m}$, or else the ibises will desert the colony (Dark-Smiley and Keinath, 2003).

The mating system of the white-faced ibis is poorly known, but they are thought to be monogamous. There have never been more than 2 adult attendants observed at any active nest (Belknap, 1957; Kotter, 1970). The events leading up to pair formation, and the duration of pair bonds are not known either (Ryder and Manry, 1994). In Utah, adults generally begin to forage in pairs one or two weeks before onset of nesting (Kotter, 1970), and in Louisiana pairs arrive at the colony "already mated” (Belknap, 1957).

As stated previously, breeding can be highly synchronous within a large colony, with courting, nest-building, incubation, and fledglings occurring at the same time (Belknap, 1957). Seven pairs of white-faced ibis nesting in the SLV all completed hatching within a 4-day period, indicating that nest initiation was highly synchronous (Schreuer, 1987). Ibises may re-nest if initial breeding attempts fail early in the season, but distinguishing between second nesting efforts and late nesting efforts is very difficult (Kotter, 1970; Bryant, 1983). The breeding season in the northern Great Plains seems to be up to 1 month later than in the southwestern United States, and this is thought to be the result of cooler early-spring temperatures in the northern areas (Kotter, 1970; Steele, 1980).

Eggs are laid from the $2^{\text {nd }}$ week of April to the last week of June in Utah, and egg laying extended over a period of 41 days in a larger colony (Kotter, 1970). Eggs are usually laid in the morning (Caspen, 1977) on every other day, and clutches are completed over a period of 5 to 8 days (Kotter, 1970; Capen, 1977). In Colorado at Monte Vista NWR, ibises usually have 1-3 eggs by the third week of May and young leave the nest in mid- to late July (Dark-Smiley and Keinath, 2003). Egg-laying dates from June 4 to July 25 in eastern Wyoming and Iowa (Findholdt, 1984; Dinsmore and Dinsmore, 1986) indicate that breeding occurs several weeks later in the northern Great Plains than in Utah, Nevada, and Colorado. This is probably due to the colder weather in northern areas during the early spring months. Hatchlings usually emerge within 24 hours of initial pipping (Kotter, 1970). Sequential eggs in the clutch usually hatch one or two days apart, although they can hatch on the same day or up to three days later (Kotter, 1970). Young are born semi-altricial (Trost, 1989). Adults brood and shade the young continuously from the time they hatch up to two weeks of age (Ryder and Manry, 1994), after which young are left unattended for up to three hours at a time until brooding ceases completely during week three (Belknap, 1957; Kotter, 1970). Both sexes brood and feed the young (Ryder and Manry, 1994). Young are independent at eight weeks of age (Kotter, 1970). There is very little information regarding dispersal. Band recoveries suggest that no yearlings and few second-year birds return to natal areas to breed in the next breeding season (Capen, 1977). Adults may leave the breeding colony after the young have fledged, but wandering seems more prevalent during prebreeding compared to postbreeding (Ryder, 1967). 


\section{Demography \& Populations}

The oldest white-faced ibis known in the wild was 14 years and 6 months (Clapp and others, 1982). In captivity, the oldest bird was at least 14 years (Stott, 1948). Based on 111 band recoveries of birds banded as nestlings in Utah, all birds died by 9 years of age (Ryder, 1967).

In the 1960s and 1970s, nesting populations and numbers of colonies in North America decreased precipitously because of pesticide contamination (mainly from organochlorines such as DDT) and loss of habitat to drought and drainage (Ryder, 1967; King and others, 1980). In the 1980s and early 1990s, distribution of the species increased as habitat improved and organochlorines were banned, reclaiming historical breeding range and expanding north to Alberta and east to North and South Dakota, Iowa, and Alabama. A single nest at Lake Washington, Florida (Brewster, 1986) and at least 2 nests at Heron Lake, Minnesota, in both 1894 and 1895 (Peabody, 1896) suggest a wider breeding distribution in the late $19^{\text {th }}$ century (Ryder and Manry, 1994).

Population numbers for white-faced ibis are difficult to assess because of a lack of census data (Ryder and Manry, 1994). Total breeding populations in the Great Basin (Idaho, Nevada, Utah) averaged about 7,500 pairs in the late 1970s and early 1980s (Sharp, 1985). In southern Idaho, the total nesting population was estimated at nearly 2,000 pairs in the mid-1980s (Taylor and others, 1989). Annual nesting populations ranged from 450 to 8,690 pairs at the Great Salt Lake, Utah, during the 1970s (Capen, 1977; Steele, 1984), from 1,400 to 5,000 pairs in Lahontan Valley, Nevada, during 19801988 (Henny and Herron, 1989), and from 600 to 2,475 pairs in Harney Basin, Oregon, during 19801987 (Ivey and others, 1988). Along the Texas coast, annual breeding populations fluctuated between 1,520 and 6,500 pairs during 1973-1990 (Mullins and others, 1982).

Breeding range and populations have expanded in the last two decades (Ryder and Manry, 1994). This is owed in part to improved nesting habitat management on Federal and state Refuges, increased planting of alfalfa used by feeding ibises (in the western United States), the banning of DDT and other pesticides in the 1970s, and improved breeding success at major nesting centers. Since 1970, nesting populations have increased dramatically in Idaho (Taylor and others, 1989), Oregon (Ivey and others, 1988), and Nevada (Henny and Herron, 1989), with more modest gains in the SLV (Ryder and Manry, 1994), California (Ryder, 1967; Ivey and Severson, 1984, Sharp, 1985), and Wyoming (Ritter and Cerovski, 1990). The first state nesting records were confirmed in Montana in 1970, in North and South Dakota in 1978 (Schmidt, 1980), and in Iowa in 1986 (Dinsmore and Dinsmore, 1986) as breeding range expanded into the northern Great Plains. The first state nesting record in New Mexico was in 1973 (Hundertmark, 1974). In the late 1970s, the breeding range expanded eastward through coastal Louisiana to southwestern Alabama, widening the zone of nesting overlap with the glossy ibis (Duncan and Johnson, 1977; Jackson and Cooley, 1978). However, Texas coastal breeding populations declined from 6,500 to 2,300 pairs between 1981 and 1990 (Ryder and Manry, 1994). In coastal Louisiana, ibis populations (predominately white-faced) appear to have declined from 12,495 to 6,255 breeding adults between 1976 and 1990 (Portnoy, 1977; Martin and Lester, 1990).

In the western United States, breeding populations fluctuate markedly at major breeding centers from year to year in response to changing habitat conditions. Breeding adults appear to be nomadic, relocating when drought or floods render traditional sites temporarily unusable (Ryder, 1967; Thompson and others, 1979; Steele, 1984; Ivey and others, 1988; Henny and Herron, 1989; Taylor and others, 1989). Similarly, birds may shift between Texas and Louisiana coastal breeding sites according to habitat conditions (King and others, 1980). Within the major breeding areas (for example, the Great Salt Lake, Harney Basin, Lahontan Valley), colony sites change from year to year depending on the local water conditions, as some sites become desiccated in dry years or are flooded in wet years (Capen, 1977; Steele, 1984; Ivey and others, 1988; Henny and Herron, 1989). 
Annual or biannual censusing of breeding colonies of white-faced ibis is comprehensive and consistent in Nevada (Henny and Herron, 1989), Oregon (Ivey and others, 1988), and Texas (Mullins and others, 1982), but is sporadic and incomplete in Idaho (Taylor and others, 1989), Wyoming (Ritter and Cerovski, 1990), Louisiana (Martin and Lester, 1990), Utah (Sharp, 1985), California, and other states (including Colorado). In view of the species’ nomadism and apparent tendency to relocate breeding centers across state lines in some years, monitoring long-term population status would require coordinated survey efforts covering the entire breeding range (Booser and Sprunt, 1980; Henny and Herron, 1989) that are repeated on a regular basis. Population surveys and status assessment in Mexico are also urgently required (Sharp, 1985).

The Breeding Bird Survey (BBS) regional trend analysis for white-faced ibis along 17 Colorado routes from 1966 to 1999 showed a positive trend estimate of $11.6(-1.6,28.6$; 95 percent CI) (Sauer and others, 2011). From 1999 to 2009, the trend was also positive and estimated to be 12.5 (-8.2, 33.8; 95 percent CI). However, the regional credibility measure for this species was the category "red,” meaning that data were deficient because of overall low abundances of ibises per route and/or the results were too imprecise to detect long-term trends.

\section{Threats}

Causes of mortality include exposure and predation (Ryder and Manry, 1994). Small nestlings left unattended may die of exposure in cold, wet weather, and large numbers of dead chicks may be found in colonies after severe thunderstorms (Kotter, 1970; Capen, 1977). Extremely high temperatures also can be fatal to nestlings (Tyler, 1933; Kingery, 1988). Abandoned or temporarily unguarded eggs and chicks are vulnerable to predation by Franklin's, California, and laughing gulls (Kotter, 1970; Capen, 1977; Alford, 1978; King, 1978), grackles (Belknap, 1957), and black-billed magpies (Kotter, 1970), although the magnitude of these losses is difficult to measure because disturbance by investigators is often a contributing factor. Kotter (1970) reported at least 28 percent egg destruction by Franklin's gulls breeding in the same colony, whereas Capen (1977) and Steele (1980) concluded that Franklin's gulls posed little or no threat to nesting ibises. Mink, weasels, striped and spotted skunks, raccoons, and coyotes sometimes raid colonies, especially when water levels are low, consuming eggs and chicks and sometimes killing adults (Kotter, 1970; Kingery, 1976; 1980; 1988; Capen, 1977; Ryder and others, 1979; Herron and others, 1987). Kotter (1970) reported "surplus killing” at one colony, possibly by mustelids, which ate very few of the eggs and chicks that were destroyed. Capen (1977) reported a similar episode in which California gulls were suspected: eggs and chicks in nearly all 600+ nests at a single colony were destroyed but left uneaten. Steele (1980) concluded that large colonies suffer higher predation rates than smaller ones, possibly because they are more conspicuous. Hatching eggs and small chicks may be killed by fire ants (Solenopsis spp.) on islands off the Texas coast (Burger and Miller, 1977). An adult ibis was attacked and killed by a northern harrier in Kansas (Rivers, 2000).

Nests, eggs, and young suffer from human disturbance, overgrazing by livestock, and, especially in the SLV, heavy predation from magpies, ravens, and raccoons. Breeding populations in Texas, Utah, and Oregon declined in the 1970s probably due to pesticides, but increased in the 1980s and 1990s. The USFWS has at various times designated the white-faced ibis as a "sensitive species," a "species of management concern," and a "category 2 candidate” for possible listing as a threatened species, based on the birds' limited number of consistent breeding sites and uncertain status (Sharp, 1985). Ryder (1998) urged Refuges in Colorado to adopt management controls to keep the white-faced ibis population in the state viable.

Hurricanes, thunderstorms, and prolonged heat waves also can disrupt breeding at individual sites (Belknap, 1957; Bryant, 1983; Kingery, 1988). Botulism regularly sickens and kills ibises in Utah 
(Wetmore, 1918). Until 1918, white-faced ibises were harvested legally in California, Oregon, Texas, and elsewhere in the United States for market and personal consumption (Bent, 1926; Pearson, 1936; Ryder, 1967). The current extent of illegal hunting in the United States is unknown, but is probably negligible. Hunting on wintering grounds in Mexico, despite legal protection (Ryder, 1967), continues to this day (recent band returns), although the impact on populations is unclear.

DDT-DDE contamination causes eggshell thinning and abnormal eggshell ultrastructure, leading to cracking, denting, or crushing of eggs during incubation. DDE residues $\geq 3-4$ parts per million (ppm) in white-faced ibis eggs have been linked to high incidences of damaged eggs, lower hatching success, reduced reproductive output, and possibly delayed breeding (Ryder and Manry, 1994). Other effects of DDT-DDE on adults is unclear. At Carson Lake, Nevada, DDE contamination apparently reduced the potential fledging production by at least 20 percent in 1985 and 1986 (Henny and Herron, 1989; Henny, 1997). Despite the 1972 ban on the use of DDT in the United States, DDE concentrations have remained high in white-faced ibis populations nesting in the Great Basin, most likely as a result of continued DDT use on birds' wintering grounds in Mexico (Capen, 1977; Henny and others, 1985; Henny and Herron, 1989). DDE-induced eggshell thinning in white-faced ibis is still considered a continuing problem in the western United States (King and others, 2003; Yates and others, 2010).

High concentrations of dieldrin in the brains and others tissues were linked to extensive mortality of nestling and juvenile white-faced ibises on the Texas coast in the early 1970s, before the use of dieldrin (aldrin) in local rice fields was phased out in the mid-1970s (Flickinger and Meeker, 1972; King and others, 1980). Potentially hazardous levels of mercury and selenium, accumulated within the breeding range, were detected in ibises nesting at Carson Lake, Nevada, but the effects of these contaminants on survival and reproduction were unknown (Henny and Herron, 1989).

Diversion of natural water supplies away from existing wetlands to irrigation projects, especially during severe droughts, has led to temporary or permanent abandonment of traditional colony sites for ibises (Weller and others, 1958; Herron and Lucas, 1978; Ryder and others, 1979; Henny and Herron, 1989). After severe drought, emergent vegetation may require several years to regenerate before it can be used by nesting ibises (Ryder, 1967; Herron and others, 1981). In the Great Basin, loss of wetland feeding habitat may be partly offset by the creation of irrigated farmlands, in which ibises forage extensively (Capen, 1977; Bray, 1986; Alcorn, 1988; Bray and Klebenow, 1988). The effects of wetland destruction on ibis populations in Mexico are unknown but are cause for concern (Sharp, 1985).

In Utah and Nevada, some breeding sites have been severely damaged by cattle grazing and trampling (Weller and others, 1958; Herron and Lucas, 1978). In Texas and Louisiana, vegetation of some colony sites has been damaged by the introduced nutria (Myocaster coypus), resulting in delayed nesting or disuse of the site (Belknap, 1957; Ogden, 1978). In some Federal and state wildlife Refuges, burning of emergent vegetation to create open water conditions for waterfowl has reduced nesting habitat for ibises (Sharp, 1985).

Humans entering active colonies may cause partial or total desertion, particularly during nestsite selection, nest-building, and incubation. Unattended eggs and small chicks are highly vulnerable to avian predators and to chilling or overheating (Belknap, 1957; Kotter, 1970; Kaneko, 1972; Capen, 1977; King, 1978; Schreur, 1987). Biologists working in active colonies should carefully schedule and limit visits to avoid disturbance during sensitive nesting states. 


\section{Management}

\section{Response to Management}

There was not a lot of information in the literature about white-faced ibis responses to different management schemes such as mowing, haying, and burning. Water-related management and agricultural practices were the most frequently encountered management themes. Competition over water rights amongst irrigation projects, municipalities, and private hunting clubs, especially during droughts, poses a continuing threat to several important colony sites in the Great Basin, including some sites in state and Federal Wildlife Refuges. Beginning in the late 1980s, negotiations among users have improved water supplies to important breeding areas in Lahontan Valley, Nevada (Sharp, 1985; Colby and others, 1991) and Harney Basin, Oregon (Ryder and Manry, 1994). During the 1989 drought, limited water allotment to Carson Lake, Nevada, was concentrated in a single management unit to accommodate ibis nesting; breeding success and total fledgling production were exceptionally high despite drought conditions (Herron and others, 1989).

Irrigated fields can be valuable feeding-sites for white-faced ibises (Bray and Klebenow, 1988). In areas where historical feeding-sites of ibises have diminished, flood irrigation of agricultural fields could be maintained or created for their use. Ibises showed a greater preference for alfalfa fields and less preference for corn, wheat-barley, pastures, and oat fields in the Lahontan Valley, Nevada. Farming practices can also enhance earthworm populations, a preferred food source for ibises (Bray and Klebenow, 1988). Applying organic fertilizers to fields would be favorable for earthworms, but pesticide spraying, burning, disking, and mowing of fields should be minimal (Edwards and Lofty, 1977). However, in Utah, ibises are blamed by ranchers for harming alfalfa crops by trampling irrigated fields and causing soil compaction (Ryder and Manry, 1994). Alcorn (1988) described ibises flattening standing alfalfa in Nevada, making it difficult or impossible to cut alfalfa for hay.

\section{Recommendations}

The U.S. Fish and Wildlife Service provided management guidelines for the Great Basin population of white-faced ibises (Sharp, 1985). Their overall goal was to maintain an average Great Basin population of at least 7,500 breeding pairs, emphasizing the maintenance of large breeding colonies. Specifically, they recommended providing habitat, including sufficient water to maintain emergent vegetation growth at Carson Lake Pasture, Stillwater NWR, Malheur Lake NWR, and the Great Salt Lake. A selection of their recommendations include:

- At Carson Lake Pasture, maintaining a 400-hectare stand of dense emergent vegetation with 5.7 million to 8.6 million cubic meters of water should provide adequate habitat of 3,000 nesting pairs.

- Work cooperativly with other land management agencies and private landowners to maintain emergent vegetation sufficient for approximately 500 pairs at Malheur Lake (NWR).

- At Stillwater NWR, integrate ibis production with diving duck production objectives and refrain from burning emergent growth in ibis colonies, especially in the spring.

- In all areas, organize and manage water delivery to maintain at least some stable hardstem bulrush (Scirpus acutus) habitat in extremely wet and extremely dry years.

- Where possible, provide shallow water feeding areas (depth up to $15 \mathrm{~cm}$ ), especially when young have hatched and are being fed (June and July).

- Eliminate cattle grazing from ibis nesting marshes

- Incoroporate nesting requirements for ibises into marsh/grassland/fire management plans 
- Monitor ibis nesting efforts on an annual basis.

Schreur (1987) studied the reproductive success of colonially-nesting Ciconiiformes, including the white-faced ibis, and the effects of public viewing in the SLV, Colorado between April 1984 and August 1985. The following recommendations were made:

- "Heronries in the SLV should be censused once a year to monitor breeding population trends. The number of nests in each heronry should be counted on one trip during the last week of May or the first week of June. All heronries should be censused to account for movement of breeding adults among heronries. A nest census is the preferred method of monitoring breeding Ciconiiformes populations over measuring reproductive success because it causes less disturbance and is less expensive. In addition, the reliability of reproductive success estimates are uncertain due to unidentified renests, unmeasured mortality of nestlings after 10 days, and unknown effects of observers.

- No recreational uses of wetlands containing heronries should be allowed from 1 April through 15 May. Ciconiiformes are selecting nest sites, constructing nests, and laying eggs during this time. Ciconiiformes will desert nests much more readily during this time than during the nestling stages (Vos, 1984).

- Public access to heronry wetlands from 16 May through 15 August should be by guided tour or in motor vehicles only. Both of these methods of public viewing restrict visitor disturbance and access. There is evidence that motor vehicles are tolerated at closer distances than persons on foot.

- Water levels should be maintained at a constant depth from 1 April through 15 August to prevent flooding or abandonment. Wetlands where Ciconiiformes forage should be drawn down periodically to 'recharge' the soil. Drawdowns decrease anaerobic soil conditions and increase the productivity of wetlands.

- Carp should be controlled to increase water clarity and aquatic plant production. Clear water enhances the visibility of prey to visually orientated predators. Enhanced aquatic plant densities will result in more prey availability.

- Hardstem bulrush should be encouraged to grow in small 'island' stands (from $20 \mathrm{~m}$ to $100 \mathrm{~m}$ in diameter) and stands larger than 0.5 ha should include openings at least $20 \mathrm{~m}$ in diameter. Hardstem bulrush is preferred to other emergent because of superior support characteristics.”

\section{Research Priorities}

The general behavior of white-faced ibises is not known, including communication, pair formation, pair-bond duration, breeding and natal dispersal, and time budgets (Ryder and Manry, 1994; Dark-Smiley and Keinath, 2003). Monitoring of pesticides and other contaminants should also be maintained, and specifically the effects of these contaminants on ibis mortality and reproduction should be studied (Ryder and Manry, 1994; Dark-Smiley and Keinath, 2003). Dark-Smiley and Keinath (2003) also suggested a need for quantifying the resources necessary for colony establishment and successful breeing of ibises. For example, studies that would determine the thresholds of wetland size, hydrology, and water quality that can support successful colonies would greatly benefit land managers seeking to maintain colony health and facilitate colony formation for ibises (Dark-Smiley and Keinath, 2003). 


\section{Bibliography}

Alcorn, J.R., 1988, The birds of Nevada: Fairview West Publishing, Fallon, Nevada.

Alford, E.H., 1978, Early nesting by white-faced ibis in relation to habitat: an adaptive advantage:

Unpublished M.S. Thesis, Brigham Young University, Provo, Utah.

Amadon, D., and Woolfenden, G., 1952, Notes on the Matthew's collection of Australian birds: Am.

Mus. Novit. No. 1564.

Amat, J.A., and Rilla, F.D., 1994, Foraging behavior of white-faced ibises (Plegadis chihi) in relation to habitat, group size, and sex: Colonial Waterbirds, v. 17, p. 42-49.

Baumgartner, F.M., and Baumgartner, A.M., 1992, Oklahoma bird life: University of Oklahoma Press, Norman, Oklahoma.

Behle, W.H., and Perry, M.L., 1975, Utah birds: check-list, seasonal and ecological occurrence charts and guides to bird finding: Utah Museum of Natural History, University of Utah, Salt Lake City, Utah.

Belknap, H.W., 1957, Observation on the white-faced ibis (Plegadis chihi) in Louisiana: Unpublished M.S. Thesis, Louisiana State University, Baton Rouge, Louisiana.

Bent, A.C., 1926, Life histories of North American marsh birds: U.S. National Museum Bulletin 135.

Blanco, G., and Rodriguez-Estrella, R., 1998, Human activity may benefit white-faced ibises overwintering in Baja California Sur, Mexico: Colonial Waterbirds, v. 21, p. 274-276.

Bohlen, H.D., 1989, The birds of Illinois: Indiana University Press, Bloomington, Indiana.

Booser, J., and Sprunt, I.V., 1980, A literature review and annotated bibliography of the Great

Basin/Rocky Mountain population of white-faced ibis: Unpublished report prepared by the National Audubon Society for the U.S. Fish and Wildlife Service, Portland, Oregon, $134 \mathrm{pp}$.

Bray, M.P., 1986, Feeding ecology of white-faced ibises in the Lahontan Valley, Nevada: P-R Report, Federal Aid Project W-53-R, Study 1, Jobs 02, Nevada Department of Wildlife, Reno, Nevada.

Bray, M.P., and Klebenow, D.A., 1988, Feeding ecology of white-faced ibises in the Great Basin Valley, USA: Colonial Waterbirds, v. 11, p. 24-31.

Brewster, W., 1886, Breeding of white-faced glossy ibis in Florida: Auk, v. 3, p. 481-482.

Bryant, R.L., 1983, White-faced ibis nests at Quivira National Wildlife Refuge: Bulletin of the Kansas Ornithological Society, v. 34, p. 26.

Burger, J., and Miller, L.M., 1977, Colony and nest site selection in white-faced and glossy ibises: Auk, v. 94, p. 664-676.

Campbell, R.W., Dawe, N.K., Cowan, I.M., Cooper, J.M., Kaiser, G.W., and McNall, M.C.E., 1990, The birds of British Columbia, Vol. 1: Royal British Columbia Museum, Victoria, Canada.

Capen, D.E., 1977, The impact of pesticides on the white-faced ibis: Unpublished PhD Dissertation, Utah State University, Logan, Utah.

Capen, D.E., 1978, Evaluating the impact of pesticides on the white-faced ibis in Utah: Proceedings of the Colonial Waterbird Group, v. 1, p. 196-201.

Capen, D.E., and Leiker, T.J., 1979, DDE residues in blood and other tissues of white-faced ibis: Environmental Pollution, v. 19, p. 163-171.

Carmona, R., Ruiz-Campos, G., Castillo-Gerrero, J.A., and Zamora-Orozco, M., 2002, Current distribution status of white-faced ibis, Plegadis chihi, in the peninsula of Baja California, Mexico, with special reference to the region of La Paz: Southwestern Naturalist, v. 47, p. 476-482.

Clapp, R.B., Klimkiewicz, M.K., and Kennard, J.H., 1982, Longevity records of North American birds: Gaviidae through Alcidae: Journal of Field Ornithology, v. 53, p. 81-124.

Cogswell, H.L., 1977, Water birds of California: University of California Press, Berkeley, California. 
Colby, B.G., McGinnis, M.A., and Rait, K.A., 1991, Mitigating environmental externalities through voluntary and involuntary water reallocation: Nevada’s Truckee-Carson River Basin: Natural Resources Journal, v. 31, p. 757-783.

Cornely, J.E., Thompson, S.P., Henny, C.J., and Littlefield, C.D., 1994, Nests and eggs of colonial birds nesting at Malheur Lake, Oregon, with notes on DDE: Northwestern Naturalist, v. 74, p. 41-48.

Custer, T.W., and Mitchell, C.A., 1989, Organochlorine contaminants in white-faced ibis eggs in southern Texas: Colonial Waterbirds, v. 12, p. 126-129.

Dark-Smiley, D., and Keinath, D.A., 2003, Species assessment for white-faced ibis (Plegadis chihi) in Wyoming: Unpublished report prepared for the U.S. Department of the Interior, Bureau of Land Management, Wyoming State Office, Cheyenne, Wyoming.

Davis, W.M., 1989, Extraordinary aggregation of white-faced ibises at a playa lake in Texas County, Oklahoma: Bulletin of the Oklahoma Ornithological Society, v. 22, p. 27.

Dinsmore, S., and Dinsmore, J.J., 1986, White-faced ibis nesting in Dickinson County, Iowa Bird Life, v. 56, p. 120-121.

Dorn, J.L., and Dorn, R.D., 1999, Wyoming birds, $2^{\text {nd }}$ edition: Mountain West Publishing, Cheyenne, Wyoming.

Ducey, J.E., 1988, Nebraska birds: breeding status and distribution: Simmons-Boardman Books, Omaha, Nebraska.

Duebbert, H.F., 1968, White-faced ibis in McIntosh County, North Dakota: Prairie Naturalist, v. 1, p. 14.

Duncan, C.D., and Johnson, P.G., 1977, First breeding record of white-faced ibis for Alabama and a new area of Plegadis sympatry: Alabama Birdlife, v. 25, p. 16.

Dunning, J.B., Jr., 1984, Body weights of 686 species of North American birds: Western Bird Banding Association Monograph, No. 1.

Earnst, S.L., Neel, L., Ivey, G.L., and Zimmerman, T., 1998, Status of the white-faced ibis: breeding colony dynamics of the Great Basin population, 1985-1997: Colonial Waterbirds, v. 21, p. 301-313.

Edwards, C.A., and Lofty, J.R., 1977, Biology of earthworms: John Wiley and Sons, New York, New York.

Faanes, C.A., and Stewart, R.E., 1982, Revised checklist of North Dakota birds: Prairie Naturalist, v. 14, p. 81-92.

Findholt, S.L., 1984, Status and distribution of herons, egrets, ibises, and related species in Wyoming: Colonial Waterbirds, v. 7, p. 55-62.

Flickinger, E.L., and Meeker, D.L., 1972, Pesticide mortality of young white-faced ibis in Texas: Bulletin of Environmental Contamination and Toxicology, v. 8, p. 165-168.

Gochfeld, M., 1973, Observations on new or unusual birds from Trinidad, West Indies, and comments on the genus Plegadis in Venezuela: Condor, v. 75, p. 474-478.

Goossen, J.P., Ealy, D.M., Judge, H., and Duncan, D.C., 1995, Distribution and breeding status of white-faced ibis, Plegadis chihi, in Canada: Canadian Field-Naturalist, v. 109, p. 391.

Hancock, J.A., Kushlan, J.A., and Kahl, M.P., 1992, Storks, ibises, and spoonbills of the world: Academic Press, London, United Kingdom.

Henny, C.J., 1997, DDE still high in white-faced ibis eggs from Carson Lake, Nevada: Colonial Waterbirds, v. 20, p. 478-484.

Henny, C.J., and Bennett, J.K., 1990, Comparison of breaking strength and shell thickness as evaluators of white-faced ibis eggshell quality: Environmental Toxicology and Chemistry, v. 9, p. 797-805.

Henny, C.J., and Herron, G.B., 1989, DDE, selenium, mercury, and white-faced ibis reproduction at Carson Lake, Nevada: Journal of Wildlife Management, v. 53, p. 1032-1045. 
Henny, C.J., Blus, L.J., and Hulse, C.S., 1985, Trends in effects of organochlorine residues on Oregon and Nevada wading birds, 1979-83: Colonial Waterbirds, v. 8, p. 117-128.

Hoffman, R., 1927, Birds of the Pacific states: Houghton Mifflin Company, Boston and New York.

Hothem, R.L., Crayon, J.J., and Law, M.A., 2006, Effects of contaminants on reproductive success of aquatic birds nesting at Edwards Air Force Base, California: Archives of Environmental

Contaminants and Toxicology, v. 51, p. 711-719.

Howell, S.N.G., and de Montes, B.M., 1989, Status of the glossy ibis in Mexico: American Birds, v. 43, p. 43-45.

Howell, S.N.G., and Webb, S., 1992, Noteworthy observations from Baja California, Mexico: Western Birds, v. 23, p. 156-163.

Hundertmark, C.A., 1974, Breeding range extensions of certain birds in New Mexico: Wilson Bulletin, v. 86, p. 298-300.

Ivey, G.L., and Severson, D.J., 1984, White-faced ibis nesting in the southern San Joaquin Valley of California: Condor, v. 86, p. 492-493.

Ivey, G.L., Stern, M.A., and Carey, C.G., 1988, An increasing white-faced ibis population in Oregon: Western Birds, v. 19, p. 105-108.

Jackson, J.A., and Cooley, C.D., 1978, Central southern region: American Birds, v. 32, p. 1171-1175. James, D.A., and Neal, J.C., 1986, Arkansas birds-their distribution and abundance: University of Arkansas Press, Fayetteville, Arkansas.

Kaneko, K.D., 1972, Nesting of the white-faced ibis (Plegadis chihi) of Utah Lake: Unpublished M.S. Thesis, Brigham Young University, City, Utah.

Kaufman, K., 1990, A field guide to advanced birding: Houghton Mifflin Company, Boston, Massachusetts.

Kelchlin, E.P., and Wright, V.L., 2002, Nestling survival of white-faced ibis in Lahontan Valley, Nevada, U.S.A.: Waterbirds, v. 25, p. 499-504.

King, K.A., 1978, Colonial wading bird survey and census techniques: in Sprunt, A., Ogden, J., and Winkler, S., eds., Wading Birds: National Audubon Society Research Report 7, New York, New York.

King, K.A., Flickinger, E.L., and Hildebrand, H.H., 1978, Shell thinning and pesticide residues in Texas aquatic bird eggs, 1970: Pesticide Monitoring Journal, v. 12, p. 16-21.

King, K.A., Meeker, D.L., and Swineford, D.M., 1980, White-faced ibis populations and pollutants in Texas, 1969-1976: Southwestern Naturalist, v. 25, p. 225-239.

King, K.A., Zaun, G.J., Schotborgh, H.M., and Hurt, C., 2003, DDE-induced eggshell thinning in whitefaced ibis: a continuing problem in the western United States: Southwestern Naturalist, v. 48, p. 356364.

Kingery, H.E., 1988, Mountain west: American Birds, v. 42, p. 1321-1324.

Kotter, B.L., 1970, An ecological natural history of the white-faced ibis (Plegadis chihi) in northern Utah: Unpublished M.S. Thesis, University of Utah, Salt Lake City, Utah.

Kushlan, J.A., and Bildstein, K.L., 1992, White ibis: in Poole, A., Stettenheim, P., and Gill, F., eds., The Birds of North America, No. 9, Acad. Nat. Sci. Phila. And Am. Ornithol.Union, Philadelphia, Pennsylvania.

Laubhan, M.K., and Gammonley, J.H., 2000, Density and foraging habitat selection of waterbirds breeding in the San Luis Valley of Colorado: Journal of Wildlife Management, v. 64, p. 808-819.

Leopold, A.S., 1959, Wildlife of Mexico-the game birds and mammals: University of California Press, Berkeley, California. 
Littlefield, C.D., 1990, Birds of Malheur National Wildlife Refuge, Oregon: Oregon State University Press, Corvallis, Oregon.

Locatelli, M.S., and Blankenship, T.E., 1973, White-faced ibis in Humboldt County, California: Murrelet, v. 54, p. 11-12.

Lockerbie, C.W., 1938, An albino white-faced glossy ibis: Condor, v. 40, p. 44.

Martin, R.P., and Lester, G.D., 1990, Atlas and census of wading bird and seabird nesting colonies in

Louisiana: 1990: Spec. Report No. 3, Louisiana Department of Wildlife and Fisheries and Louisiana Natural Heritage Program, Baton Rouge, Louisiana.

Merrill, E.H., Kohley, T.W., Herdendorf, M.E., Reiners, W.A., Driese, K.L., Marrs, R.W., and Anderson, S.H., 1996, Wyoming Gap Analysis: Terrestrial vertebrate species map atlas for birds: Final Report, Wyoming Cooperative Fish and Wildlife Unit, University of Wyoming, Laramie, Wyoming.

Molina, K.C., and Sturm, K.K., 2004, Annual colony site occupation and patterns of abundance of breeding cormorants, herons, and ibis at the Salton Sea: Studies in Avian Biology, v. 27, p. 42-51.

Mullins, H.L., Slack, R.D., Chaney, A.H., Telfair, R.C., II, Paul, R.T., Blankinship, D.R., Blacklock, G.W., King, K.A., Kennedy, S., and Smith, J.C., 1982, An atlas and census of Texas waterbird colonies 1973-1980: Caesar Kleberg Wildlife Research Institute, Texas A \& I University, Kingsville, Texas.

Oberholser, H.C., 1974, Bird life of Texas, Vol. 1: University of Texas Press, Austin, Texas.

Ogden, J.C., 1978, Recent population trends of colonial wading birds on the Atlantic and Gulf coastal plains: Pp. 79-238 in Farmer, D.S., King, J.R, and Parkes, K.C., eds., Wading birds: National Audubon Society Research Report 7.

Palmer, R.S., 1962, Handbook of North American birds, Vol. 1: Yale University Press, New Haven, Connecticut.

Parkes, K.C., 1955, Systematic notes on North American birds: 1. The herons and ibises

(Ciconiiformes): Ann. Carnegie Mus., v. 33, p. 287-293.

Peabody, P.B., 1896, White-faced glossy ibis nesting in Minnesota: Auk, v. 13, p. 79.

Pearson, T.G., 1936, Birds of America: Garden City Publishing Company, Inc., Garden City, New York.

Pesavento, P.A., Barr, B., Riggs, S.M., Eigenheer, A.L., Pamma, R., and Walker, R.L., 2008, Cutaneous pythiosis in a nestling white-faced ibis: Veterinary Pathology, v. 45, p. 538-541.

Petersen, W.M., 1953, A food habit study of the white-faced glossy ibis: Unpublished.

Portnoy, J.W., 1977, Nesting colonies of seabirds and wading birds-coastal Louisiana, Mississippi, and Alabama: FWS/OBS-77/07, U.S. Fish and Wildlife Service, Biological Service Program, Washington, D.C.

Pratt, H.D., 1976, Field identification of white-faced and glossy ibises: Birding, v. 8, p. 1-5.

Remsen, J.V., Jr., Swan, M.M., Cardiff, S.W., and Rosenberg, K.V., 1991, The importance of the ricegrowing region of south-central Louisiana to winter populations of shorebirds, raptors, waders, and other birds: Journal of Louisiana Ornithology, v. 1, p. 35-47.

Rilling, R., and Falzone-Schrim, D., 1993, Nesting colony study in the San Luis Valley: Colorado Division of Wildlife, Monte Vista, Colorado.

Ritter, S.A., and Cerovski, A.O., 1990, 1990 update on the status and distribution of colonially nesting waterbirds in Wyoming: Nongame Spec. Re., Wyoming Game and Fish Department, Cheyenne, Wyoming.

Rivers, J.W., 2000, Northern harrier predation of white-faced ibis: Wilson Bulletin, v. 112, p. 416-417. 
Robertson, W.B., Jr., Woolfenden, G.E., 1992, Florida bird species: an annotated list: Florida Ornithological Society, Special Publication No. 6.

Rodgers, J.A., Jr., 1976, Spread-wing sunbathing by juvenile white-faced ibis: Auk, v. 93, p. 375-376.

Russell, R.W., 1983, Delaware’s first white-faced ibis: Delmarva Ornithol., v. 16, p. 17-18.

Ryder, R.A., 1950, New breeding records for Colorado: Condor, v. 52, p. 133-134.

Ryder, R.A., 1967, Distribution, migration and mortality of the white-faced ibis (Plegadis chihi) in

North America: Bird-Banding, v. 38, p. 257-277.

Ryder, R.A., 1980, Effects of grazing on bird habitats: Pp. 51-66 in Management of western forests and grasslands for nongame birds, U.S. Forest Service General Technical Report INT-86, Ogden, Utah.

Ryder, R.A., 1993, The status of white-faced and glossy ibises in Colorado: Journal of the Colorado Field Ornithologists, v. 27, p. 102.

Ryder, R.A., 1994, Waterbirds of the San Luis Valley, past, present and future: Journal of the Colorado Field Ornithologists, v. 28, p. 100.

Ryder, R.A., 1998, White-faced ibis, Plegadis chihi: Pp. 64-65 in Kingery, H.E., ed., Colorado Breeding Bird Atlas, Colorado Bird Atlas Partnership, Copublished by Colorado Division of Wildlife, Denver, Colorado.

Ryder, R.A., and Manry, D.E., 1994, White-faced ibis (Plegadis chihi): American Ornithologists’ Union, Washington, D.C.

Ryder, R.A., and Manry, D.E., 1994, White-faced ibis (Plegadis chihi): Poole, A., ed., The Birds of North America Online, Ithaca, Cornell Laboratory of Ornithology, Retrieved from the Birds of North America Online: http://bna.birds.cornell.edu/bna/species/130. Accessed 1 July 2011.

Ryder, R.A., Graul, W.D., and Miller, G.C., 1979, Status, distribution and movements of Ciconiiformes in Colorado: Proceedings of the Colonial Waterbird Group, v. 3, p. 49-57.

Sabo, T., 1992, Plegadis ibis - a change in status: Birders Journal, v. 1, p. 247-256.

Safran, R.J., Colwell, M.A., Isola, C.R., and Taft, O.E., 2000, Foraging site selection by nonbreeding white-faced ibis: Condor, v. 102, p. 211-215.

Salt, W.R., and Salt, J.R., 1976, The birds of Alberta: Hurtig Publishers, Edmonton, Alberta.

Sauer, J.R., Hines, J.E., Fallon, J.E., Pardieck, K.L., Ziolkowski, D.J., Jr., and Link, W.A., 2011, The North American Breeding Bird Survey, Results and Analysis 1966 - 2009: Version 3.23.2011. Online at http://www.mbr-pwrc.usgs.gov/bbs/bbs.html. Accessed on 12 July 2011.

Schmidt, R.A., 1980, First breeding records of the white-faced ibis in North Dakota: Prairie Naturalist, v. 12, p. 21-23.

Schreur, J.L., 1987, Ciconiiform reproductive success and public viewing in the San Luis Valley, Colorado: Unpublished M.S. Thesis, Colorado State University, Fort Collins, Colorado.

Sharp, B.S., 1985, White-faced ibis management guidelines: Great Basin population: U.S. Fish and Wildlife Service, Portland, Oregon.

Sclater, W.H., 1912, A history of the birds of Colorado: Witherby and Co., London, United Kingdom.

Shaffer, J.A., Knutsen, G.A., Martin, R.E., and Brice, J.S., 2007, Pattern and potential causes of whitefaced ibis, Plegadis chihi, establishment in the northern prairie and parkland region of North America: Canadian Field-Naturalist, v. 121, p. 46.

Sharp, B., 1985, White-faced ibis management guidelines: Great Basin population: Unpublished report, U.S. Fish and Wildlife Service, Portland, Oregon.

Shuford, W.D., Warnock, N., Molina, K.C., and Sturm, K.K., 2002, The Salton Sea as critical habitat to migratory and resident waterbirds: Hydrobiologia, v. 473, p. 255-274.

Stahlecker, D.W., 1989, White-faced ibis breeding in Rio Arriba County: second verified nesting location for New Mexico: New Mexico Ornithological Society Bulletin, v. 17, p. 2-6. 
Steele, B.B., 1980, Reproductive success of the white-faced ibis: effects of pesticides and colony characteristics: Unpublished M.S. Thesis, Utah State University, Logan, Utah.

Steele, B.B., 1984, Effects of pesticides on reproductive success of white-faced ibis in Utah, 1979: Colonial Waterbirds, v. 7, p. 80-87.

Stott, K., Jr., 1948, Notes on the longevity of captive birds: Auk, v. 65, p. 402-405.

Taft, M.R., Mauser, D.M., and Arnold, T.W., 2000, Breeding ecology of white-faced ibis (Plegadis chihi) in the upper Klamath Basin, California: Western North American Naturalist, v. 60, p. 403-409.

Taylor, D.M., Trost, C.H., and Jamison, B., 1989, The biology of the white-faced ibis in Idaho: Western Birds, v. 20, p. 125-133.

Thompson, S.P., Littlefield, C.D., and Ryder, R.A., 1979, Historical review and status of colonial nesting birds on Malheur National Wildlife Refuge: Proceedings of the Colonial Waterbird Group, v. 3, p. 156-164.

Trost, C.H., 1989, White-faced ibis, Plegadis chihi: Pp. 57-58 in Clark, T.W., Harvey, A.H., Dorn, R.D., Genter, D.L., and Groves, C., eds., Rare, sensitive, and threatened species of the Greater Yellowstone Ecosystem: Northern Rockies Conservation Cooperative, Jackson, Wyoming.

Tweit, B., and Flores, B., 2006, White-faced ibis in Washington in 2001: a significant incursion and attempted breeding: Washington Birds, v. 9, p. 1-7.

Tweit, B., and Johnson, J., 1992, Oregon/Washington region: American Birds, v. 46, p. 1171-1173.

Tyler, J.G., 1933, Items from an oologist’s notebook: Condor, v. 35, p. 186-188.

U.S. Fish and Wildlife Service, 1987, Migratory nongame birds of management concern in the United States: the 1987 list: Office of Migratory Bird Management, U.S. Fish and Wildlife Service, Washington, D.C.

U.S. Fish and Wildlife Service, 1991, Endangered and threatened wildlife and plants: animal candidate review for listing as endangered or threatened species, proposed rule: Federal Register, Washington, D.C.

Vos, D.K., 1984, Responses of breeding great blue herons to human disturbance in northcentral Colorado: Unpublished M.S. Thesis, Colorado State University, Fort Collins, Colorado.

Waldron, M., 1990, First Tennessee record of white-faced ibis: Migrant, v. 61, p. 65-66.

Weller, M.W., Wingfield, B.H., and Low, J.B., 1958, Effects of habitat deterioration on bird populations of a small Utah marsh: Condor, v. 60, p. 220-226.

Wetmore, A., 1918, The duck sickness in Utah: U.S. Department of Agriculture Bulletin, v. 672, p. 125.

Wetmore, A., 1926, Observations on the birds of Argentina, Paraguay, Uruguay, and Chile: Bulletin of the U.S. National Museum 133.

Williams, S.O., III, 1977, Colonial waterbirds of the Mexican Plateau: Proceedings of the 1977 Conference of the Colonial Waterbird Group, Southern, W.E., ed.

Yates, M.A., Fuller, M.R., Henny, C.J., Seegar, W.S., and Garcia, J., 2010, Wintering area DDE source to migratory white-faced ibis revealed by satellite telemetry and prey sampling: Ecotoxicology, v. 19, p. 153-162.

Yee, D.G., Deuel, B.E., and Bailey, S.F., 1990, Middle Pacific coast region: American Birds, v. 44, p. 491-494.

Young, V.E., and Pence, D.B., 1979, Neottialges (Pelecanectes) ibisicola sp. n. (Acari: Hypoderidae) from the subcutaneous tissues of the white-faced ibis (Plegadis chihi)[Ciconiiformes:

Threskiornithidae]): Journal of Parasitology, v. 65, p. 659-661.

Zaun, B.J., King, K.A., Hurt, C., and Schotborgh, H.M., 2003, First record of white-faced ibis, Plegadis chihi, nesting in Arizona: Southwestern Naturalist, v. 48, p. 130-131. 


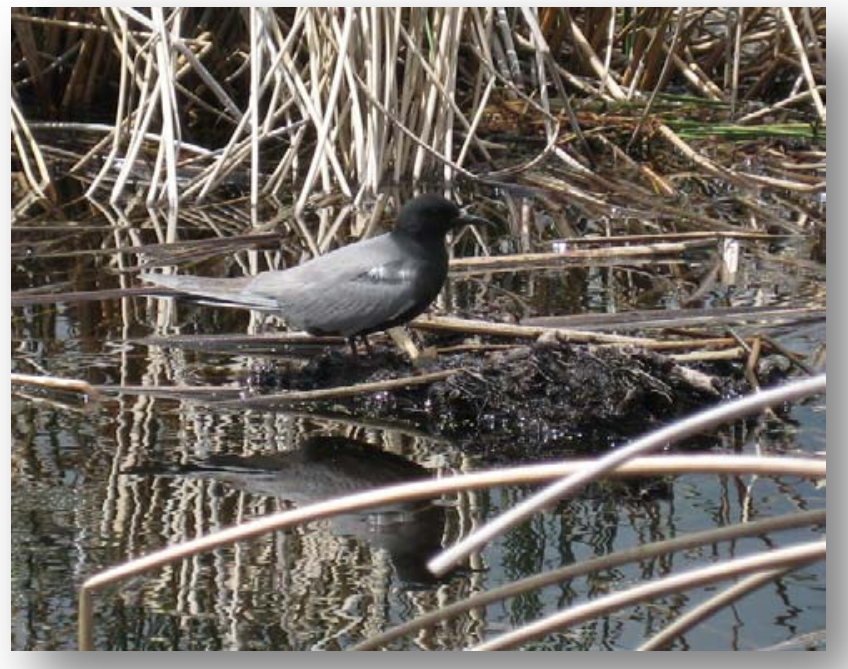

Black Tern, Montana, courtesy of Jessi Miller.

\section{Black Tern (Chlidonias niger)}

\section{Introduction}

The black tern (Chlidonias niger

surinamensis) has been a species of concern in North America because of continental population declines, particularly since the 1960s (Shuford, 1999). This species was proposed for listing under the Federal Endangered Species Act, but the U.S. Fish and Wildlife Service (USFWS) concluded that there was not enough information to make a listing determination (U.S. Fish and Wildlife Service, 1991). The black tern has a Heritage status ranking of 'imperiled' in the state of Colorado (Naugle,

2004). Loss of wetlands on breeding grounds and migration routes is probably a major cause of population declines in this species, but food supplies may have also been reduced through agricultural control of insects and overfishing in marine winter ranges (Dunn and Agro, 1995). The black tern has been a nontarget beneficiary of protection programs aimed at conserving habitat for upland nesting waterfowl. The most comprehensive of such habitat programs is the North American Waterfowl Management Plan (NAWMP) (http://www.nawmp.ca/; accessed 13 June 2011). No Breeding Bird Survey trend analyses are available for the black tern along Colorado routes from 1968 to 2009 (Sauer and others, 2011).

A simple Google search on the Internet for "Chlidonias niger" revealed 432,000 results and a Google Scholar search provided 2,450 results (accessed 11 July 2011). "Black tern” revealed 761,000 results through Google and 4,120 results through Google Scholar (accessed 11 July 2011).

\section{Natural History}

\section{Systematics and Morphology}

The black tern has a holarctic distribution with two subspecies: Chlidonias niger niger (European black tern) and C. niger surinamensis (Gmelin)(North American black tern) (Cramp, 1985; Dunn and Agro, 1995; American Ornithologists' Union, 1998). It is in the Order Charadriiformes, the Family Laridae, and subfamily Sterninae. The species is a small $(23-26 \mathrm{~cm}, 50-60 \mathrm{~g})$ dark tern, unmistakable in alternate plumage with the head, neck, and underparts blackish (blacker in males), the wings (paler on coverts), back, rump, and tail smoky grey, the undertail coverts white, and the underwings whitish; the leading edge of the inner wing is white (Novak, 1992; Dunn and Agro, 1995; Howell and Webb, 1995). In the late summer and fall, the underparts are blotched black and white during prebasic molt. The bill is black, eyes are dark, and legs are dark reddish brown. In basic plumage, the head, neck, and underparts are white with a black crown patch extending down onto the auriculars and a blackish patch occurring at the sides of the chest. The upperparts are smoky grey, darker on the mantle and lesser upperwing coverts; the underwings are pale grey. Juvenile plumage is similar to basic plumage, but the upperparts are washed brown, the upperwing coverts are edged pale, and the underwing coverts are whitish. The first summer plumage resembles basic adult plumage, but some birds have blackish patches on the underparts. 


\section{Distribution}

In North America, the black tern breeds from southeastern Yukon, southwestern Northwest Territories, central and northeastern British Columbia, northern Alberta, northern Saskatchewan, northern Manitoba, northern Ontario, southern Quebec, southern New Brunswick and central Nova Scotia south to south-central California, northern Nevada, northern Utah, Colorado, Nebraska, northern Iowa, northeastern Illinois, northern Indiana, north-central Ohio, northwestern Pennsylvania, northern New York, northwestern Vermont, and Maine (Shuford, 1999). The species' population is generally patchily distributed on the fringes of its range, particularly in the Northeast and in arid portions of the West. The largest populations are concentrated in zones of highly productive wetlands, particularly in the prairies of Alberta, Saskatchewan, Manitoba, North Dakota, South Dakota, and Minnesota (Dunn and Agro, 1995; Peterjohn and Sauer, 1997).

In Colorado, breeding populations of black terns were likely more common in the past (Nelson, 1998). A “large” colony nested in a "marshy tract along the Arkansas River" at Fort Lyon in 1964 (Coues, 1874). Eggs presented to the Colorado College Museum documented breeding near Greeley in 1902 (Sclater, 1912). In 1907-1908, Hersey and Rockwell found two nests along the chain of marshes north of Barr Lake (Rockwell, 1911; Niedrach and Rockwell, 1939), and a few pairs regularly nested at this site at least through 1938 (Nelson, 1998). Black terns no longer nest in these areas (Nelson, 1998). The most recent Colorado Breeding Bird Atlas listed probable nesting sites in all but two of the eastern latilongs, but no confirmed sites in the eastern part of the state. Definite breeding was confirmed only for San Luis State Wildlife Area and Alamosa and Arapaho NWRs (Nelson, 1998).

The black tern winters mainly in marine and marine-coastal areas in the Americas along the Pacific Coast from southern Mexico east and south to Peru, and on the Atlantic coast from eastern Panama east along northern South America to French Guiana (Dunn and Agro, 1995; Howell and Webb, 1995; AOU, 1998).

\section{Migration}

During migration, the black tern is found throughout the interior of North America south of the breeding range, along both coasts and the interior of Middle America, along the Atlantic coast from Nova Scotia south to Florida, the West Indies, and Trinidad, and in northern South America east to French Guiana and south to Ecuador and Peru, and often far out at sea (Dunn and Agro, 1995; AOU, 1998). The species is casual to accidental in Hawaii, Alaska, Newfoundland, Prince Edward Island, Clipperton Island, Bermuda, Chile, Brazil, Uruguay, and northern Argentina.

Black terns gather at favorite feeding sites after young fledge and then migrate singly or in small groups, mainly inland on a broad front through the United States (Dunn and Agro, 1995). Large flocks of up to thousands may form, probably where food is concentrated, particularly in coastal or marine habitat south of the breeding range and at a few favored sites in the interior of the western U.S (Carmona and others, 2011). No data are available on the length of time terns remain at migratory stopover sites (Dunn and Argo, 1995). Fall movements may begin by late July, and most birds leave northern breeding grounds by mid- to late August and are scarce in the United States after September. Spring migration is more rapid and less coastal than in fall, occurring primarily on a broad front through the interior of the United States. Spring movements occur primarily from mid-April through late May with stragglers into June. The degree to which terns exhibit fidelity to migratory stopovers or particular portions of the marine winter range are not known (Dunn and Argo, 1995). 
Habitat

Black terns nest in shallow, highly productive wetlands with emergent vegetation in freshwater (sometimes brackish or alkaline) marshes, along prairie sloughs, lake margins, edges of islands or slowmoving rivers, wet meadow, bogs, shrub-swamps, and, in California, cultivated ricefields or flooded fallow fields (Dunn and Agro, 1995). Weller and Spatcher (1965) reported that during wetland succession the hemi-marsh stage (roughly 50:50 open water and vegetation) was ideal for most marshnesting birds, including black terns. The interspersion of water and vegetation and the size of the water area was perhaps of more importance than the ratio of water to cover. Studies by Tilghman (1980), Chapman-Mosher (1986), Rabenold (1986; 1987), Hickey (1997), Hickey and Malecki (1997), and Mazzocchi and others (1997) also support the conclusion that black terns generally select nest sites with an approximate 50:50 vegetation cover to open water ratio that is well interspersed with water; open water, though, can range from 5 to 95 percent of the area of breeding marshes (Powell, 1991).

Black terns can rapidly colonize restored marshes or ones rejuvenated after drought, and numbers may initially increase as vegetative conditions improve and later decline as the vegetation deteriorates (Weller and Spatcher, 1965; Weller, 1979; Hemesath and Dinsmore, 1993). The relationship of marsh size and landscape features to numbers of black terns is complex (Shuford, 1999). Brown and Dinsmore (1986) found black terns preferred marshes $>20$ ha and only rarely used smaller marshes (5 ha minimum) unless they were part of larger wetland complexes. Naugle (1997) used GIS techniques to develop a model of important black tern habitat in eastern South Dakota and found that terns nested in larger basins and wetland complexes. He used a 50 percent probability of occurrence (from a logistic regression analysis) as a conservative estimator, and delineated the minimum area requirement for the black tern as a semipermanent wetland basin of 12.4 ha. Naugle (1997) also found that the area requirements of black terns varied in response to the structure of the wetland landscape. Black terns did not widely use wetland landscapes with a low density of primarily small wetlands, where few nesting wetlands occurred and potential food sources were spread over large distances. Instead, their wetland area requirements were small ( $6.5 \mathrm{ha}$ ) in high wetland density landscapes with a mixture of large and small wetlands; 32.6 ha in landscapes of predominately large wetlands; and, 15.4 ha in landscapes with mostly small wetlands. Black terns were also more likely to occur in wetlands with surrounding grasslands that were $<50$ percent tilled for agriculture (Naugle, 1997). The average one-way foraging distance of black terns from colonies range from about 1 to $4 \mathrm{~km}$ (Chapman-Moser, 1986), which may suggest why smaller marshes support terns only when those small marshes are part of a larger mosaic of marshes. Hickey and Malecki (1997) considered black terns to be area dependent because of the species' loose coloniality and scattered nest spacing.

Black terns use a wide variety of vegetation types in nesting areas, including cattails (Typha spp.), bulrushes (Scirpus spp.), burreed (Sparganium spp.), sedges (Carex spp.), rushes (Juncus spp.), spikerush, pickerelweed (Pontederia spp.), smartweed (Polygonum spp.), reed-canary grass (Phalaris arundinacea), tufted hairgrass (Deschampsia caespitosa), arrowhead (Sagittaria spp.), spatterdock (Nuphar spp.), water lilies (Nymphaea spp.), wild rice (Zizania aquatica), marsh horsetail (Equisetum fluviatile), cultivated rice (Oryza spp.), and, in northern areas, buttonbrush (Cephalanthus occidentalis) and willows (Salix spp.) in shrub-swamps (Dunn and Agro, 1995). In Colorado, black terns breed in large cattail marshes next to open water (Andrews and Richter, 1992). Rockwell (1911) described a nest at Barr Lake as built on a dense carpet of cattails blown over by the wind about $3 \mathrm{~m}$ from shore in a sparsely covered spot amid dense cattail growth and over about $15 \mathrm{~cm}$ of water, another on a large round top of a duck blind floating in almost waist deep water at the edge of cattails in a small "rushbound" pond, and a third on a mass of dead floating cattails. 
Ideal nest site characteristics reduce nest loss from wind and waves and provide adequate cover for chicks (Chapman-Mosher, 1986; Dunn and Agro, 1995), but presumably also provide camouflage to incubating adults without greatly hindering their entry to the site or reducing their visibility of approaching predators. Nest sites allow for easy access of chicks and adults to open water even after vegetation density has increased by seasonal growth; dense homogeneous stands of vegetation are generally avoided (Shambaugh, 1995). Vegetation around nest sites generally varies from sparse to moderately dense (Shuford, 1999). Emergent vegetation at nests grows from about $<0.25$ to $0.5 \mathrm{~m}$ high at nest initiation to $>1 \mathrm{~m}$ before hatching (Dunn and Agro, 1995). Nest sites are usually adjacent to expanses of open water; mean distances of nests from open water have ranged from 0.1 to $35.9 \mathrm{~m}$ (Dunn, 1979; Novak, 1990; Mazzocchi and Hickey, 1997; Hickey and Malecki, 1997). Black terns may choose an optimum distance from both the water edge and upland edge that reduces the effects of wind and wave action and predators (Hickey and Malecki, 1997). Wetland habitat with lots of patch fragmentation and increased edges might negatively influence reproductive success. Water depth averages 25 to $134 \mathrm{~cm}$, but depth varies considerably among sites, habitats, and years (Gould, 1974; Stern, 1987; Novak, 1992; Laurent, 1993; Faber, 1996; Hickey and Malecki, 1997; Mazzocchi and others, 1997). Areas of open water or sparse vegetation are used for foraging (Chapman-Mosher, 1986; Shambaugh, 1995). Water clarity at nesting and foraging sites may also be an important habitat need (Richardson, 1996).

Nest success is highly variable among regions, years, and colonies, and this has made it difficult to identify consistent relationships between nest success and habitat characteristics (Mazzocchi and others, 1997). In British Columbia, experiments showed that nests surrounded by vegetation or on platforms suffered the least from wind and wave action or fluctuating water levels (Chapman-Mosher, 1986). Nests in reed canary grass (Phalaris arundinaceae) survived water-level fluctuations better than those in other habitats, and fledging success was greatest in areas with the shortest plants, which included horsetail (Equisetum spp.). In northern New York, water levels at successful nests were not significantly different than levels at failed nests (Mazzacchi and others, 1997). Conversely, in Wisconsin and Minnesota, Laurent (1993) and Faber (1996) found that failed nests had significantly lower minimum water depths than those that successfully hatched young. In Oregon, nest success and fledging rates did not differ among habitats of varying vegetative composition and water depth (Stern and others, 1985). Several other studies failed to find a correlation between nest success and nest-site characteristics, including Bergman and others (1970), Dunn (1979), and Hickey (1997).

Naugle and others (1999) conducted bird surveys throughout South Dakota in 1995 and 1996 to assess the effects of woody vegetation encroachment on nongame wetland birds. They found that wetland bird species richness decreased as the extent of woody vegetation encompassing wetland perimeters increased. Logistic regression analyses indicated that black terns were less likely to occur in wetlands surrounded by trees than in more open wetlands.

Migrating black terns in the United States use freshwater lakes, rivers, and other interior wetlands (Shuford, 1999). They also forage over plowed fields and coastal wetlands (Dunn and Agro, 1995). In arid areas of the West in fall, thousands of black terns congregate at highly productive interior wetlands, such as Malheur NWR, Lower Klamath NWR, and the Salton Sea (Shuford, 1999). At the Salton Sea, large numbers of terns forage over irrigated fields. South of the United States, black terns are found mainly over offshore marine waters where water is 30 to $450 \mathrm{~m}$ deep (up to $2000 \mathrm{~m}$ ) in areas of high productivity, such as the Panama upwelling and edges of the Gulf of Mexico currents (Dunn and Agro, 1995). Black terns in the Gulf of Mexico concentrate over the freshwater plume of the Mississippi River because of the low surface-water salinity and high productivity (Ribic and others, 1997). 
During the winter season, black terns are found mostly in marine waters within $30 \mathrm{~km}$ of land, with occasional sightings to as much as $3500 \mathrm{~km}$ offshore (Dunn and Agro, 1995). They also use coastal areas and productive freshwater lakes near coasts.

\section{Foraging Habits}

Breeding black terns are mainly insectivorous, but fish make up a large part of the diet in some habitats and regions (Dunn and Agro, 1995). Fish may dominate the diet by mass and provide an important source of calcium (Beintema, 1997). Black terns circle low over foraging areas with slow, shallow wingbeats and bill pointed downwards (Goodwin, 1960). The birds often flock where food is concentrated. They may hover briefly before suddenly dropping or swooping to the surface to capture prey on the water surface, or pick insects off vegetation (Dunn and others, 2009). Sometimes, black terns hunt from a perch over water (Welham and Ydendberg, 1993). They may also catch insects in the air, especially when insect swarms occur over land. Prior to pesticide use, black terns commonly foraged for insects behind plows and over grain fields (Gabrielson, 1914; Pittman, 1927; Roberts, 1932; Brewer, 1969; James and Neal, 1986). Larson and Leyva (2007) observed 3,000 black terns foraging among hundreds of breaching manta rays one kilometer offshore the coast of Guerrero, Mexico.

\section{Breeding}

Black terns nest semicolonially, placing their nests in clusters in favorable areas of marshes; clusters are typically about 11-50 nests but can range from two to hundreds (Dunn and Argo, 1995). Nests are usually 5 to $20 \mathrm{~m}$ apart, but sometimes as close as $1 \mathrm{~m}$. Up to 25 percent to 30 percent of birds nest "solitarily," or from 20 to $30 \mathrm{~m}$ up to $600 \mathrm{~m}$ from other nests. Birds from these subgroups in a wetland area may behave as a single colony in their flock behavior. Territories of nests are defended to about $2 \mathrm{~m}$. Nests are small cuplike gatherings of aquatic vegetation usually built on floating substrates of matted or decaying marsh vegetation and commonly mixed with mud (Shuford, 2004). Floating substrates can also be detached root masses, logs and boards, muskrat (Ondatra zibethicus) feeding platforms or clippings, algae or peat mats, lily pads, dried cowpies, and old nests of grebes, American Coots (Fulica americana), and Forster's terns (Sterna forsteri). These substrates are usually anchored to or lodged in emergent vegetation or dense beds of submerged rooted aquatics (Novak, 1992; Dunn and Agro, 1995). Nonfloating substrates include muskrat lodges, raised mud patches, marshy hummocks, rooted flattened vegetation, and upturned tree roots with attached vegetation.

Nest site selection and nest building are rapid, with the time from colony occupation to egg laying being as little as 4 days (Dunn and Argo, 1995). Initial nesting attempts are fairly synchronous, but renesting frequently prolongs the breeding season. Egg-laying has occurred as early as 11 May in lowland California, where the majority of clutches are initiated in the second or third week of May. At higher elevations or more northerly latitudes, most clutches are initiated from the third week of May through the first week of June. Average clutch size is $2.6(n=2297)$; 3-egg clutches account for about 65 percent of nests, 2-egg clutches for 25 percent of nests, 1-egg clutches are uncommon, and clutches of 4 to 6 are rare (Dunn and Argo, 1995). Eggs require 19 to 23 days to hatch (Novak, 1992; Dunn and Argo, 1995). Earliest hatching is in early June, but most occurs in late June and early July. Chicks can fly as early as 18 to 19 days, most at 20 to 24 days, and some probably at 25 days (Dunn and Agro, 1995). Most young fledge in mid- to late July. 


\section{Demography and Populations}

Little is known about the demography of black tern populations in North America (Nisbet, 1997). Nesting success varies widely across their range, but on average there is probably less than one chick raised per nest (Dunn and Agro, 1995). Birds can renest at least $42 \mathrm{~km}$ from their original nest, which makes estimating annual reproductive success of birds that fail on their first attempt extremely difficult (Mazzocchi and Muller, 1993). Nests or eggs are often lost to bad weather, effects of wind and waves, or changing water levels (Dunn and Agro, 1995). Chick loss is also highly variable and its causes are generally unknown.

The North American Waterbird Conservation Plan provides the only available population estimate for black tern in North America - from 100,000 to 500,000 breeding individuals (Kushlan and others, 2002). This is a speculative estimate based on the judgment of species experts and information from the literature (Naugle, 2004). The largest breeding populations are likely in North Dakota (83,000 to 86,000 as estimated by Igl and Johnson, 1997), South Dakota (Peterjohn and Sauer, 1997), and Minnesota (Baker and Hines, 1996). In Canada, black tern populations may be larger than in the United States (Naugle, 2004). An estimate of from 2,873 to 14,996 breeding pairs in Ontario (Austen, 1994) is the only regional estimate for any province in Canada. The best information on continental population trends (since 1966) is from the North American Breeding Bird Survey (BBS; Robbins and others, 1986). While the BBS is designed to survey mostly passerine species, data are collected on all species encountered during surveys. Interpreted cautiously because BBS data are inherently biased, there was indication that black terns declined survey-wide at an average rate of 3.1 percent annually from 19661996. This period coincided with extensive wetland losses over much of the range (Dahl, 1990; 2000). Fewer declines in black terns were evident after 1980 (Peterjohn and Sauer, 1997). The BBS trends for black terns from 1980 to 2007 in Region 6 of the U.S. Fish and Wildlife Service were actually found to be increasing (an adjusted trend index of 5.26; $P<0.1$ ) with 53 routes surveyed across the region (Sauer and others, 2011). There were no results available on black tern trends in the BBS specifically for the state of Colorado (data were too sparse). However, during the Colorado Breeding Bird Atlas surveys, the largest number of black terns were found in the San Luis Valley (SLV) (Shuford, 1999).

\section{Threats}

\section{Sources of Mortality}

Predators of black tern eggs or chicks are the great blue heron (Ardea herodias), black-crowned night-heron (Nycticorax nycticorax), great horned owl (Bubo virginianus), mink (Mustela vison), and Norway rat (Rattus norvegicus) (Dunn and Agro, 1995). Other potential predators of eggs or chicks are northern harrier (Circus cyaneus), ring-billed gull (Larus delawarensis), American crow (Corvus brachyrhynchos), common raven (Corvus corax), raccoon (Procyon lotor), muskrat, long-tailed weasel (Mustela frenata), and snapping turtle (Chelydra serpentine) (Gerson, 1988; Novak, 1992; Dunn and Agro, 1995). Adult birds have been taken by northern harrier and a large fish (Dunn and others, 2009). Adults have also been attacked by common ravens (Dunn and others, 2009).

Nest losses from flooding are common in black tern breeding colonies (Gilbert and Servello, 2005). Mosher (1986), Macikunas (1993), and Hickey (1997) reported nest losses from flooding during each year of the four, seven, and two years of their studies, respectively. Heath (2004) suggested that predation was the primary factor limiting chick survival in Maine colonies of black terns. 


\section{Loss and Degradation of Habitat}

The major factors cited as causes for black tern population declines throughout North America are loss, degradation, isolation, and fragmentation of habitat via drainage for agriculture or development (Shuford, 1999). Wetland loss in the United States has already been addressed earlier in this document. Rabenold (1987) expressed concern that habitat loss resulted in local marshes that were too small or were not part of larger marsh complexes and therefore were not suitable habitat for black terns. Degradation of habitat can occur by plant succession, increasing or decreasing water levels, introduction of exotic species, and reduction in water quality, which may alter both the food web and vegetative structure of wetlands (Novak, 1992). Competition for scarce water supplies in the arid West may impact breeding marshes. Mazzocchi and Muller (1995) suggested that as the quantity and quality of nesting habitat declines, the negative impact of factors such as predation, human disturbance, and adverse weather may increase, thereby reducing productivity. Little is known about loss or degradation of winter or migratory staging habitat. Nisbet (1997) observed that because black terns spend 8 to 9 months of the year on salt water, factors affecting the wintering grounds could be equally or more important than ones on the breeding grounds. For instance, black terns may be adversely affected by overfishing in their wintering habitats (Dunn and Agro, 1995).

Other threats to black tern populations cited in the literature include human disturbance, disease, predation, pesticides or other contaminants, introduced species, and inadequacy of existing regulatory mechanisms (Shuford, 1999). Human disturbance can expose chicks to adverse weather or directly destroy the nests. Black terns sometimes die of botulism, but this disease or the various parasites harbored by the species do not seem to be major causes of mortality (Novak, 1992; Dunn and Agro, 1995). Predation could also limit reproductive success, and Brewer (1991) suggested that increasing predator populations might be one of the multiple factors responsible for population declines in Michigan. Dunn and Agro (1995) and Weseloh and others (1997) reviewed the literature on concentrations of contaminants, such as organochlorine, PCBs, and metals, in black tern eggs, but found no evidence of effects of such contaminants oon reproduction. However, pesticides may indirectly affect black terns by reducing insect foods (Shuford, 1999).

The introduced marsh plant purple loosestrife (Lythrum salicaria) crowds out native emergent and forms stands too dense for nesting black terns (Seyler, 1991; Whitt and others, 1999; Blossey and others, 2001). Terns are apparently responding favorably to recent vegetation removal in the Columbia Basin of Washington, however, where purple loosestrife and phragmites (Phragmites australis) have been choking out marshes (Shuford, 1999).

There are currently no mandates or regulatory mechanisms for protecting the species and its habitats on the winter range (Shuford, 1999).

\section{Management}

\section{Response to Management}

Little is known about the effects of burning, mowing, or grazing on black terns (Zimmerman and others, 2002). Because wetland suitability varies with yearly fluctuations of water levels and subsequent changes in vegetation, black terns use different wetlands or different locations within wetlands from year to year (Bailey, 1977; Carroll, 1988; Dunn and Agro, 1995). In South Dakota, black tern presence was positively correlated with the total area of semipermanent wetlands in the surrounding landscape (Naugle and others, 1999; 2000; 2001). Thus, it is important to protect and maintain wetland complexes (Dunn and Agro, 1995). In Nebraska, successional changes (for example, wooded vegetation 
encroachment) within the channel of the Platte River have reduced the quality of river edge vegetation formerly occupied by black terns (Faanes and Lingle, 1995).

In the northern Great Plains, cattails (Typha spp.) have overgrown many wetlands, contributing to a decline in the numbers of black terns (Linz and others, 1994; Linz and Blixt, 1997). Since 1991, wildlife agencies have applied glyphosate-based herbicide to cattail-dominated wetlands with the objectives of increasing duck abundance and reducing crop-depredating blackbird populations. In 1990 and 1991, glyphosate-based herbicide was aerially applied to cattail-dominated wetlands in North Dakota to assess the influence of habitat changes on birds. Numbers of black terns were positively correlated with open water and dead cattails. Black tern numbers were also positively related to the number of mallards, blue-winged teal, redheads, and yellow-headed blackbirds, suggesting that there were some common habitat requirements among these species. Researchers concluded that cattail management programs designed specifically to enhance duck use and decrease red-winged blackbird numbers would probably benefit black terns (Linz and others, 1994; Linz and Blixt, 1997).

Restored wetlands can provide nesting habitat for black terns (Svedarsky, 1992; Delehanty and Svedarsky, 1993). Black terns nested in a newly restored wetland in Minnesota each year of a 3-year study. The rapid colonization of the restored wetland was attributed to the availability of flooded, dead vegetation (Delehanty and Svedarsky, 1993). In Iowa, black terns were present, but did not nest in wetlands that had been restored for 1-4 years; the study did not examine restored wetlands older than 4 years (VanRees-Siewert, 1993; VanRees-Siewert and Dinsmore, 1996). Preliminary analysis of data from North Dakota and South Dakota indicated that black terns are more common on natural wetlands than restored wetlands (Naugle and others, 2001).

A study conducted by Shealer and Haverland (2000) revealed that neither hatching success (proportion of nests from each treatment group that hatched $>1$ egg) nor fledgling success (proportion of chicks fledged from all eggs that hatched) were negatively affected by investigator disturbance (repeated nest visits and trapping and banding of adults). Black tern mortalities due to utility wire collisions have been reported, but appear to occur infrequently (Thompson, 1978; Dunn and Agro, 1995).

\section{Recommendations}

To provide suitable habitat for black terns in most regions of North America, managers should maintain or create emergent marshes with an approximate 50:50 vegetation: open water ratio with a good interspersion of vegetation and water (Shuford, 1999). Brown and Dinsmore's (1986) work also suggests that black terns would benefit from creation or restoration of marshes $>20$ ha or marshes of $>5$ and $<20$ ha situated within a wetland complex. Naugle's (1997) research indicated that the overall minimum area requirement for black terns is 12.4 ha of semipermanent wetland, but this requirement can be lowered to 6.5 ha in landscapes of high wetland density that contain a mixture of large and small wetlands. For western New York, Hickey (1997) suggested that in impoundments managed for black terns, habitat should be in unbroken patches $>10$ ha, especially in marsh units $<20$ ha. In large marsh units, maintaining habitat patches of $>20$ ha should be attempted.

Below is a selection of citations describing more responses to different management schemes and recommendations found in the literature:

- The Tonawanda complex in western New York is managed for black terns by draining and discing to favor burreed, an important nesting habitat, and muskrats, which provide nest sites and open up the marsh vegetation (Adams, 1990; Hickey, 1992; Seyler, 1991; Hickey, 1997; Hickey and Malecki, 1997). Marshes are drawn down in May, disced in July or August, and subsequently reflooded. Hickey (1997) recommended that marshes managed for black terns 
should be placed in a 4- to 6-year cycle of drawdown followed by flooding in years 2 to 5 . In the first year following flooding, water levels should be kept higher than normal to inhibit undesirable vegetation, such as purple loosestrife, and to allow muskrat populations to build up. After intentional or natural removal of water for one or more seasons, black terns almost always colonize impoundments the year following reflooding, and peak numbers usually occur in the second and third years after reflooding (Hickey and Malecki, 1997). In the first year after drawdown, vegetation responds, muskrat populations grow, and black tern nesting is probably limited by lack of suitable nesting substrates. In the second and third year, muskrat feeding and house-building activities remove vegetation, improving the interspersion of vegetation to water and providing nesting substrates. However, some researchers have questioned the extent to which muskrats are beneficial to black terns, noting that muskrats often cut down large areas of protective marsh vegetation, making those areas unsuitable for tern nest sites, and usurp floating nests or artificial nest platforms (Shuford, 1999).

- The black tern was chosen as an indicator species in the Lake Ontario-St. Lawrence River hydrosystem for its response to water-level changes (Desgranges and others, 2006). Black terns were more abundant in marshes with reduced water-level fluctuation. Because black terns build crude, typically floating nest platforms of dead aquatic vegetation, they can be particularly prone to inundation during flooding. Where water-level increases were rapid or moderate, observed breeding populations of black terns were reduced by 84 percent or more (Desgranges and others, 2006).

- Timmermans and others (2008) examined associations between breeding marsh bird abundances and Great Lakes hydrology. From 1995-2002, Lakes Erie and Huron-Michigan experienced water-level declines. Abundance of black terns declined within the marshes of these lakes during the same period. They concluded that long-term changes and annual water-level fluctuations are important abiotic factors affecting the abundance of some marsh-dependent birds in Great Lakes coastal marshes.

- Gilbert and Servello (2005) suggested that management actions that lessen large water-level increases during the period of tern nesting would reduce the proportions of nests lost to flooding in Maine. Early spring water levels that are exceptionally low may increase the risks of nest losses to flooding if nests are established on more stable substrates lower in the wetland basin. Floating nesting platforms placed in nesting areas prior to the breeding season may be beneficial.

- In Minnesota, black terns colonized a marsh the year following reflooding and peak populations occurred in the second and third years after reflooding (Delehanty and Svedarsky, 1993).

- Seyler (1991) and Hickey (1997) felt that elevated perches would benefit black terns because they use them for copulation, resting, and sites for feeding recently fledged young.

- Linz and Blixt (1997) recommended the use of aerially-sprayed herbicides to open up cattaildominated marshes to manage for wetland features that benefit black terns on a local scale. Aquatic herbicides could be used with a creativity and precision difficult to achieve with other methods, and the time between treatments may be from 8 to 10 years. They also suggested that vegetation management treatments be staggered within and among wetland complexes to diversify successional stages of emergent vegetation and maintain avian diversity on a more regional scale.

- Other alternatives for vegetation management of benefit to black terns that could be considered include regulation of muskrat populations, water-level control, livestock grazing, prescribed burning, mowing, discing, crushing, excavating, and blasting with explosives (Hickey, 1997; Linz and Blixt, 1997). 
- Removal of purple loostrife by uprooting plants, water-level manipulation, mowing, burning, flooding, or herbicide application can eliminate small and young stands but is costly, requires continued long-term maintenance, and, in the case of herbicides, is nonselective and environmentally degrading (Malecki and others, 1993).

- Faber (1996) studied use and reproductive success of black terns on artificial nest platforms along the Mississippi River from 1989 to 1991. Platforms were significantly more successful at hatching young than were natural nests in 1990, but results were equivocal for the combined period 1989 to 1991 (Faber, 1996). In northern New York, Mazzocchi and Hickey (1997) found nest success on artificial platforms was higher than on natural substrates in 1995 and lower in 1996. In perhaps the first attempt at providing artificial nest platforms in 1925, R. J. Niedrach scattered some square pieces of board in a cattail marsh at Mile High Duck Club in the Barr Lake drainage, and half a dozen nests were constructed on them (Bailey and Niedrach, 1965). Shealer and others (2006) studied the effect of floating nest platforms on breeding performance of black terns and found that eggs laid on platforms were significantly larger than those laid on natural substrates, suggesting that the platforms were occupied by healthier birds. More research is needed on the effects of artificial nest platforms and breeding success of black terns (Shuford, 1999).

\section{Research Priorities}

The following research priorities on black terns were found in the literature:

- Additional research on the effects of artificial nest platforms and breeding success of black terns (Shuford, 1999).

- Regional population and habitat surveys (Naugle, 2004).

- Collection of population demographic data (Naugle, 2004). This includes measurement of adult survival rates, characterizing chick survival rates, and the contribution of renesting to annual productivity (Naugle, 2004).

- Ecology and survival of black terns on the wintering grounds where they spend six to seven months of each year (Naugle, 2004).

\section{Bibliography}

Adams, D.J., 1990, Population status and ecology of the black tern (Chlidonias niger) at the Iroquois/Tonawanda/Oak Orchard complex: Unpublished report, St. John Fisher College, Rochester, New York.

Alcorn, J.R., 1942, Birds affected by botulism at Soda Lake, Nevada: Condor, v. 44, p. 80-81. Alcorn, J.R., 1946, The birds of Lahontan Valley, Nevada: Condor, v. 48, p. 129-138.

Allen, J., Nuechterlein, G., and Buitron, D., 2007, Resident nongame waterbird use following biomanipulation of a shallow lake: Journal of Wildlife Management, v. 71, p. 1158-1162.

American Ornithologists' Union, 1998, Check-list of North American Birds, $7^{\text {th }}$ edition: American Ornithologists’ Union, Washington, D.C.

Austen, M.J.W., 1994, Ontario birds at risk: status and conservation needs: Federation of Ontario Naturalists, Don Mills, Ontario, and Long Point Bird Observatory, Port Rowan, Ontario, Canada.

Baggerman, B., Baerends, G.P., Heikens, H.S., and Mook, J.H., 1956, Observations on the behaviour of the black tern, Chlidonias niger (L.), in the breeding area: Ardea, v. 44, p. 2-71. 
Bailey, P.F., 1977, The breeding biology of the black tern (Chlidonias niger surinamensis):

Unpublished M.S. Thesis, University of Wisconsin, Oshkosh, Wisconsin.

Baker, R., and Hines, J., 1996, Black tern sightings in Minnesota 1990-1995: The Loon, v. 68, p. 137140.

Barker, W.T., Sedivec, K.K., Messmer, T.A., Higgins, K.F., and Hertel, D.R., 1990, Effects of specialized grazing systems on waterfowl production in southcentral North Dakota: Transactions of the North American Wildlife and Natural Resources Conference, v. 55, p. 462-474.

Barrett, G.M., and Kay, D.G., 1997, Northern extension to the known breeding range of the black tern, Chlidonias niger, in the Northwest Territories: Canadian Field-Naturalist, v. 111, p. 469.

Beintema, A.J., 1997, European black terns (Chlidonias niger) in trouble: examples of dietary problems: Colonial Waterbirds, v. 20, p. 558-565.

Bent, A.C., 1921, Life histories of North American gull and terns: U.S. National Museum Bulletin, 113.

Bergman, R.D., Swain, P., and Weller, M.W., 1970, A comparative study of nesting Forster's and black terns: Wilson Bulletin, v. 82, p. 435-444.

Beyersbergen, G.W., Niemuth, N.D., and Norton, M.R., coordinators, 2004, Northern Prairie and Parkland Waterbird Conservation Plant (a plan associated with the Waterbird Conservation for the Americas initiative): Prairie Pothole Joint Venture, Denver, Colorado, 183 pp.

Blokpoel, H., and Weseloh, D.V.C., 1997, Status, biology and management of the black tern in North America: Introduction to the symposium: Colonial Waterbirds, v. 20, p. 556-557.

Blossey, B., Skinner, L.C., and Taylor, J., 2001, Impact and management of purple loosestrife (Lythrum salicaria) in North America: Biodiversity and Conservation, v. 10, p. 1787-1807.

Brewer, A.D., 1969, Black terns feeding after ploughs: Breeding Birds, v. 62, p. 282.

Brown, M., and Dinsmore, J.J., 1986, Implications of marsh size and isolation for marsh bird management: Journal of Wildlife Management, v. 50, p. 392-397.

Campbell, R.W., 1970, Occurrence and nesting of black terns in southwestern British Columbia: Condor, v. 72, p. 500.

Campbell, R.W., Dawe, N.K., McTaggart-Cowan, I., Cooper, J.M., Kaiser, G.W., and McNall, M.C.E., 1990, The birds of British Columbia. Vol II. Nonpasserines. Diurnal birds of prey through woodpeckers: Royal British Columbia Museum and Canadian Wildlife Service, Victoria, B.C.

Carmona, R., Arce, N., Ayala-Perez, V., and Danemann, G., 2011, Migratory patterns of the black tern (Chlidonias niger) at the Ojo de Liebre Wetland Complex, Baja California Sur, Mexico: Southwestern Naturalist, v. 56, p. 255-259.

Carroll, J.R., 1988, Status and breeding ecology of the black tern (Chlidonias niger) in New York: Kingbird, v. 38, p. 159-172.

Chapman, B., and Forbers, L.S., Observations on detrimental effects of great blue herons on breeding black terns: Journal of Field Ornithology, v. 55, p. 251-252.

Chapman-Mosher, B.A., 1986, Factors influencing reproductive success and nesting strategies in black terns: Unpublished PhD Dissertation, Simon Fraser University, Burnaby, British Columbia, Canada.

Cooper, J.M., and Campbell, R.W., 1997, Surveys of selected and traditional black tern (Chlidonias niger) colonies in British Columbia in 1996: Colonial Waterbirds, v. 20, p. 574-581.

Coues, E., 1874, Birds of the Colorado valley: U.S. Government Printing Office, Washington, D.C.

Craik, S.R., Titman, R.D., Rousseau, A., and Richardson, M.J., 2006, First report of black terns breeding on a coastal barrier island: Wilson Journal of Ornithology, v. 118, p. 104-106.

Cramp., S., ed., 1985, Chlidonias niger Black tern: Pp. 143-155 in The birds of the western palearctic, Volume 4, Oxford University Press, Oxford.

Cuthbert, N.L., 1954, A nesting study of the black tern in Michigan: Auk, v. 71, p. 36-63. 
Dahl, T.E., 1990, Wetland losses in the United States 1780’s to 1980’s: U.S. Department of the Interior, Fish and Wildlife Service, Washington, D.C.

Dahl, T.E., 2000, Status and trends of wetlands in the conterminous United States 1986 to 1997: U.S. Department of the Interior, Fish and Wildlife Service, Washington, D.C.

Davis, T.A., and Ackerman, R.A., 1985, Adaptations of black tern (Chlidonias niger) eggs for water loss in a moist nest: Auk, v. 102, p. 640-643.

Delahanty, D.J., and Svedarsky, W.D., 1993, Black tern colonization of a restored prairie wetland in northwestern Minnesota: Prairie Naturalist, v. 25, p. 213-218.

Delphey, P.J., and Dinsmore, J.J., 1993, Breeding bird communities of recently restored and natural prairie potholes: Wetlands, v. 13, p. 200-206.

Desgranges, J.L., Ingram, J., Drolet, B., Morin, J., Savage, C., and Borcard, D., 2006, Modelling wetland bird response to water level changes in the Lake Ontario-St. Lawrence River hydrosystem: Environmental Monitoring and Assessment, v. 113, p. 329-365.

Doane, L.A., 1972, Behavior of black terns on their nesting grounds: Inland Bird Banding, v. 44, p. 136144.

Dunn, E.H., 1979, Nesting biology and development of young in Ontario black terns: Canadian FieldNaturalist, v. 93, p. 276-281.

Dunn, E.H., and Agro, D.J., 1995, Black tern (Chlidonias niger): American Ornithologists’ Union, Washington, D.C., 24 pp.

Eddy, J., 1961, Nesting habits of the black tern: Flicker, v. 33, p. 3-4, p. 14-15.

Eichhorst, B.A., and Reed, J.R., 1985, Renesting of a black tern: North American Bird Bander, v. 10, p. 8.

Einarsen, A.S., 1941, The effect upon the black tern of a change in its habitat: Murrelet, v. 22, p. 19.

Einsweiler, S.S., 1988, Black tern nesting biology in Cheboygan County, Michigan: Unpublished M.S. Thesis, Department of Biology, Central Michigan University, Mount Pleasant, Michigan.

Faanes, C.A., 1979, Status of the black tern in western Wisconsin: Passenger Pigeon, v. 41, p. 124-128.

Faanes, C.A., and Lingle, G.R., 1995, Breeding birds of the Platte River Valley of Nebraska: Northern Prairie Wildlife Research Center home page: Online at http://www.npwrc.usgs.gov/resource/distr/birds/platte/platte.htm. Accessed 1 July 2011.

Faber, R.A., 1990, Nesting ecology of the black tern on the Upper Mississippi River National Wildlife and Fish Refuge and Trempealeau National Wildlife Refuge: Unpublished report to U.S. Fish and Wildlife Service, St. Mary’s College, Winona, Minnesota.

Faber, R.A., 1992, The black tern: effects of water level fluctuations on hatching success and a census of nesting on pools 5 and 7: Unpublished final report, FWS grant agreement 14-16-003-91-984.

Faber, R.A., 1996, Impacts of artificial nest platforms and water levels on hatching success in black terns: Colonial Waterbirds Society Bulletin, v. 20, p. 53. Abstract only.

Faber, R.A., and Hickey, J.J., 1973, Eggshell thinning, chlorinated hydrocarbons and mercury in inland aquatic birds eggs, 1969 and 1970: Pesticide Monitoring Journal, v. 7, p. 27-36.

Firstencel, H., 1987, The black tern (Chlidonias niger): breeding ecology in upstate New York and results of pesticide residue analysis: Unpublished M.S. Thesis, State University New York, Rockport, New York.

Frank, R., Van Hove Holdrinet, M., and Rapley, W.A., 1975, Residue of organochlorine compounds and mercury in birds' eggs from the Niagara Peninsula, Ontario: Archives of Environmental Contamination and Toxicology, v. 3, p. 205-218.

Frederickson, L.H., and Taylor, T.S., 1982, Management of seasonally flooded impoundments for wildlife: U.S. Department of the Interior, Fish and Wildlife Service, Resource Publication 148. 
Gabrielson, I.N., 1914, Breeding birds of a Clay County, Iowa, farm: Wilson Bulletin, v. 26, p. 69-81.

Gilbert, A.T., and Servello, F., 2005, Water level dynamics in wetlands and nesting success of black terns in Maine: Waterbirds, v. 28, p. 181-187.

Goodwin, R.E., 1959, Flight preening and related aerial activities in birds, particularly the black tern: Auk, v. 76, p. 521-523.

Goodwin, R.E., 1960, A study of the ethology of the black tern, Chlidonias niger surinamensis (Gmelin): Unpublished PhD Dissertation, Cornell University, Ithaca, New York.

Gould, G.I., Jr., 1974, Breeding success of piscivorous birds at Eagle Lake, California: Unpublished M.S. Thesis, Humboldt State University, Arcata, California.

Grinnell, J., Dixon, J., and Linsdale, J.M., 1930, Vertebrate natural history of a section of northern California through the Lassen Peak region: University of California Publications in Zoology, v. 35.

Grue, C.E., De Weese, L.R., Mineau, P., Swanson, G.A., Foster, J.R., Arnold, P.M., Huckins, J.N., Sheehan, P.J., Marshall, W.K., and Ludden, A.P., 1986, Potential impacts of agricultural chemicals on waterfowl and other wildlife inhabiting prairie wetlands: an evaluation of research needs and approaches: Transactions of the North American Wildlife and Natural Resources Conference, v. 51, p. 357-383.

Haney, J.C., 1986, Seabird patchiness in tropical oceanic waters: the influence of sargassum reefs: Auk, v. 103, p. 141-151.

Heath, S.R., 2004, Nest success and chick survival of black terns in Maine: effects of predation on breeding productivity: Unpublished M.S. Thesis, University of Maine, Orono, Maine.

Heinz, G.H., Erdman, T.C., Haselgine, S.D., and Stafford, C., 1985, Contaminant levels in colonial waterbrids from Green Bay and Lake Michigan, 1975-1980: Environmental Monitoring and Assessment, v. 5, p. 113-236.

Hemesath, L.M., and Dinsmore, J.J., 1993, Factors affecting bird colonization of restored wetlands: Prairie Naturalist, v. 25, p. 1-11.

Hickey, J.M., 1997, Breeding biology and population dynamics of the black tern in western New York: Unpublished M.S. Thesis, Cornell University, Ithaca, New York.

Hickey, J.M., and Malecki, R.A., 1997, Nest site selection of the black tern in western New York: Colonial Waterbirds, v. 20, p. 582-595.

Higgins, K.F., Naugle, D.E., and Forman, K.J., 2002, A case study of changing land use practices in the northern Great Plains, U.S.A.: an uncertain future for waterbird conservation: Waterbirds, v. 25 (Special Publication 2), p. 42-50.

Hoffmann, P.W., 1926, Nesting of the black tern in Wisconsin: Auk, v. 43, p. 86-87.

Howell, S.N.G., and Webb, S., 1995, A guide to the birds of Mexico and northern Central America: Oxford University Press, New York, New York.

Igl, L.D., and Johnson, D.H., 1997, Changes in breeding bird populations in North Dakota: 1967 to 1992-93: Auk, v. 114, p. 74-92.

James, D.A., and Neal, J.C., 1986, Arkansas birds: their distribution and abundance: University of Arkansas Press, Fayetteville, Arkansas.

Johnson, R.R., D.E. Naugle, M.E. Estey and K.F. Higgins. 1996. Characteristics of eastern South Dakota wetland basins and implications of changes in jurisdictional wetland definitions. Transactions of the North American Wildlife and Natural Resources Conference 61: 127-136.

Johnston, R.F., and Klaas, E.E., 1961, Probably breeding of the black tern in Kansas: Kansas Ornithological Society Bulletin, v. 12, p. 23.

Kantrud, H.A. 1986. Effects of vegetation manipulation on breeding waterfowl in prairie wetlands-a literature review. U.S. Fish and Wildlife Service Technical Report Number 3. 
Kantrud, H.A., and Stewart, R.E., 1984, Ecological distribution and crude density of breeding birds on prairie wetlands: Journal of Wildlife Management, v. 48, p. 426-437.

Kennedy, C.H., 1914, The effects of irrigation on bird life in the Yakima Valley, Washington: Condor, v. 16, p. 250-255.

Knutson, M.G., 1991, Characteristics of black tern (Chlidonias niger) nesting habitat at Lakeview Wildlife Management Area, New York: Kingbird, v. 41, p. 228-235.

Kudell-Ekstrum, J., and Rinaldi, T., 2004, Conservation assessment for black tern (Chlidonias niger) Linnaeus: Unpublished report, USDA Forest Service, Eastern Region. Available online http://www.fs.fed.us/r9/wildlife/tes/ca-overview/docs/Black\%20Tern\%20Draft.pdf, Accessed 13 June 2011.

Kushlan, J.A., Steinkamp, M.J., Parsons, K.C., Capp, J., and others, 2002, Waterbird Conservation for the Americas: The North American Waterbird Conservation Plan (Version 1), Waterbird Conservation for the Americans, Washington, D.C.

Larson, K.W., and Leyva, J.E.M., 2007, Wintering black terns foraging among manta rays in Coastal Guerrero, Mexico: Waterbirds, v. 30, p. 448-449.

Laurent, S.M., 1993, Impact of water level on black tern (Chlidonias niger) hatching success: Unpublished B.A. Thesis, Saint Mary’s College, Winona, Minnesota.

Ligas, F.J., 1952, Migration, nesting, and food studies of the piscivorous birds of the island region of Lake Erie: Unpublished M.S. Thesis, Ohio State University, Columbus, Ohio.

Linz, G.M., and Blixt, D.C., 1997, Black terns benefit from cattail management in the northern Great Plains: Colonial Waterbirds, v. 20, p. 617-621.

Linz, G.M., Bergman, D.L., Blixt, K.C., and Bleier, W.J., 1994, Response of black terns (Chlidonias niger) to glyphosate-induced habitat alterations on wetlands: Colonial Waterbirds, v. 17:160-167.

Lee, R.C., Jr., 1984, Nesting biology of the black tern (Chlidonias niger) in rice fields of the Central Valley, California: Unpublished M.S. Thesis, California State University, Sacramento, California.

Malecki, R.A., Blossey, B., Hight, S.D., Schroeder, D., Kok, L.T., and Coulson, J.R., 1993, Biological control of purple loosestrife: a case for using insects as control agents, after rigorous screening, and for integrating release strategies with research: Bioscience, v. 43, p. 680-686.

Maxson, G.A.D., 1989, Marsh hawk predation on black tern and pectoral sandpiper: Prairie Naturalist, v. 10, p. 25-26.

Maxson, S.J., Fieberg, J.R., and Riggs, M.R., 2007, Black tern nest habitat selection and factors affecting nest success in northwestern Minnesota: Waterbirds, v. 30, p. 1-9.

Mazzocchi, I.M., Hickey, J.M., and Miller, R.L., 1997, Productivity and nesting habitat characteristics of the black tern in northern New York: Colonial Waterbirds, v. 20, p. 596-603.

Murphy, R.C., 1938, Oceanic birds of South America: William Macmillan Company, American Museum of Natural History, New York, New York.

McNicholl, M.K., 1975, Larid site tenacity and group adherence in relation to habitat: Auk, v. 92, p. 98104.

Naugle, D.E., 1997, Habitat area requirements of prairie wetland birds in eastern South Dakota:

Unpublished PhD Dissertation, South Dakota State University, Brookings, South Dakota.

Naugle, D.E., 2004, Black tern (Chlidonias niger surinamensis): a technical conservation assessment: Unpublished report prepared for the USDA Forest Service, Rocky Mountain Region, Species Conservation Project. Available online http://www.fs.fed.us/r2/projects/scp/assessments/blacktern.pdf. Accessed on 13 June 2011.

Naugle, D.E., Higgins, K.F., and Nusser, S.M., 1999, Effects of woody vegetation on prairie wetland birds: Canadian Field-Naturalist, v. 113, p. 487-492. 
Naugle, D.E., Higgins, K.F., Estey, M.E., Johnson, M.E., and Nusser, S.M., 2000, Local and landscapelevel factors influencing black tern habitat suitability: Journal of Wildlife Management, v. 64, p. 253260.

Naugle, D.E., Johnson, R.R., Estey, M.E., and Higgins, K.F., 2001, A landscape approach to conserving wetland bird habitat in the Prairie Pothole Region of eastern South Dakota: Wetlands, v. 21, p. 1-17.

Nelson, D.L., 1998, Black tern, Chlidonias niger: Pp. 194-195 in Kingery, H.E., ed., Colorado Breeding Bird Atlas, Colorado Bird Atlas Partnership, Copublished by Colorado Division of Wildlife, Denver, Colorado.

Niedrach, R.J., and Rockwell, R.B., 1939, Birds of Denver and mountain parks: Denver Museum of Natural History Popular Series, No. 5, Denver, Colorado.

Niemuth, N.D., and Solberg, J.W., 2003, Response of waterbirds to number of wetlands in the Prairie Pothole Region of North Dakota, USA: Waterbirds, v. 26, p. 233-238.

Nisbet, I.C.T., 1997, Status, biology and management of the black tern: symposium summary and overview: Colonial Waterbirds, v. 20, p. 622-625.

Novak, P.G., 1992, Black tern, Chlidonias niger: Pp. 149-169 in Schneider, K.J., and Pence, D.M., eds., Migratory nongame birds of management concern in the northeast: U.S. Department of the Interior, U.S. Fish and Wildlife Service, Newton Corner, Massachusetts.

Peterjohn, B.G., and Sauer, J.R., 1997, Population trends of black terns from the North American Breeding Bird Survey 1966-1996: Colonial Waterbirds, v. 20, p. 566-573.

Pittman, H.H., 1927, The black terns of Saskatchewan: Condor, v. 29, p. 140-143.

Powell, A.N., 1991, Monitoring black tern populations in Minnesota in association with the USFWS waterfowl production survey: Unpublished report to Minnesota Department of Natural Resources, Nongame program, St. Paul, Minnesota.

Provost, M.W., 1947, Nesting birds in the marshes of northwest Iowa: American Midland Naturalist, v. 38, p. 485-503.

Rabenold, P.P., 1986, 1986 survey of black terns (Chlidonias niger) breeding in Indiana: Unpublished report, Nongame and Endangered Wildlife Program, Indiana Department of Natural Resources, Indianapolis, Indiana.

Rabenold, P.P., 1987, 1987 survey of black terns (Chlidonias niger) breeding in Indiana: Unpublished report, Nongame and Endangered Wildlife Program, Indiana Department of Natural Resources, Indianapolis, Indiana.

Ribic, C.A., Davis, R., Hess, N., and Peake, D., 1997, Distribution of seabirds in the northern Gulf of Mexico in relation to mesoscale features: initial observations: ICES Journal of Marine Science, v. 54, p. 545-551.

Richardson, F., 1967, Black tern nest and egg moving experiments: Murrelet, v. 48, p. 52-56.

Richardson, M., 1996, A survey of black terns (Chlidonias niger) occurring in Prince Edward County and adjacent areas of Northumberland, Hastings and Lennox and Addington/Frontenac counties, with observations of habitat and use of nest platforms in the 1995 breeding season: Unpublished report to Canadian Wildlife Service, Nepean, Ontario.

Robbins, C.S., Bystrak, D., and Geissler, P.H., 1986, The breeding bird survey: its first fifteen years, 1965-1979: U.S. Fish and Wildlife Service Resource Publication Number 157.

Roberts, T.S., 1932, The birds of Minnesota: University of Minnesota Press, Minneapolis, Minnesota. Rockwell, R.B., 1911, Notes on the nesting of the Forster and black terns in Colorado: Condor, v. 13, p. 57-63.

Sanders, T.A., and Edge, W.D., 1998, Breeding bird community composition in relation to riparian vegetation structure in the western United States: Journal of Wildlife Management, v. 62, p. 461-473. 
Sauer, J.R., Hines, J.E., Fallon, J.E., Pardieck, K.L., Ziolkowski, D.J., Jr., and Link, W.A., 2011, The North American Breeding Bird Survey, Results and Analysis 1966 - 2009, Version 3.23.2011, U.S. Geological Survey Patuxent Wildlife Research Center, Laurel, MD. Available online http://www.mbrpwrc.usgs.gov/bbs/bbs.html. Accessed 13 June 2011.

Saunders, A.A., 1933, The black tern in Connecticut in spring: Auk, v. 50, p. 105.

Sclater, W.H., 1912, A history of the birds of Colorado: Witherby and Company, London, United Kingdom.

Servello, F.A., 2000, Population research priorities for black terns developed from modeling analyses: Waterbirds, v. 23, p. 440-448.

Seyler, D.A., 1991, The status of the 1991 nesting population of black terns (Chlidonias niger) at the Tonawanda Wildlife Management Area: Unpublished report, Bureau of Wildlife, New York State Department of Environmental Conservation.

Shambaugh, N., 1995, Black tern (Chlidonias niger) population levels and nest site selection in Vermont, 1994: Unpublished report to Nongame and Natural Heritage Program, Vermont Fish and Wildlife Department, Waterbury, Vermont.

Shealer, D.A., and Haverland, J.A., 2000, Effects of investigator disturbance on the reproductive behavior and success of black terns: Waterbirds, v. 23, p. 15-23.

Shealer, D.A., Buzzell, J.M., and Heiar, J.P., 2006, Effect of floating nest platforms on the breeding performance of black terns: Journal of Field Ornithology, v. 77, p. 184-194.

Sheppard, R.W., 1953, The black tern as an insect-eater: Canadian Field-Naturalist, v. 66, p. 129. Shuford, W.D., 1999, Status assessment and conservation plan for the black tern (Chlidonias niger surinamensis) in North America: U.S. Fish and Wildlife Service, Denver, Colorado, 129 pp. Shuford, W.D., 2008, Black Tern (Chlidonias niger): Studies of Western Birds, v. 1, p. 193-198. Shuford, W.D., and Gardali, T., eds., 2008, California bird species of special concern: a ranked assessment of species, subspecies, and distinct populations of birds of immediate conservation concern in California: Studies of Western Birds, v. 1, Western Field Ornithologists, Camarillo, California, and California Department of Fish and Game, Sacramento, California.

Shutler, D., Mullie, A., and Clark, R.G., 2000, Bird communities of prairie uplands and wetlands in relation to farming practices in Saskatchewan: Conservation Biology, v. 14, p. 1441-1451.

Sirois, J., and Fournier, M.A., 1993, Clarification of the status of the black tern (Chlidonias niger) in the Northwest Territories, Canada: Colonial Waterbirds, v. 16, p. 208-212.

Stern, M.A., 1987, Site tenacity, mate retention, and sexual dimorphism in black terns: Unpublished M.S. Thesis, Oregon State University, Corvallis, Oregon.

Stern, M.A., and Jarvis, R.L., 1991, Sexual dimorphism and assortative mating in black terns: Wilson Bulletin, v. 103, p. 266-271.

Stewart, R.E., and Kantrud, H.A., 1972, Population estimates of breeding birds of North Dakota: Auk, v. 89, p. 766-788.

Steward, R.E., and Kantrud, H.A., 1984, Ecological distribution and crude density of breeding birds on prairie wetlands: Journal of Wildlife Management, v. 48, p. 426-437.

Svedarsky, W.D., 1992, Biological inventory of a multi-purpose flood control impoundment in northwestern Minnesota and potentials for nongame and game bird management: Final report, Northwest Agricultural Experiment Station, University of Minnesota, Crookston, Minnesota.

Thompson, L.S., 1978, Transmission line wire strikes: mitigation through engineering design and habitat modification: Pp. 27-52 in Avery, M.L., ed., Impacts of transmission lines on birds in flight, Publication 78/48, U.S. Fish and Wildlife Service, Office of the Biological Service, Washington, D.C. Tilghman, N.G., 1980, The black tern survey, 1979: Passenger Pigeon, v. 42, p. 1-8. 
Timmermans, S.T.A., Badzinski, S.S., and Ingram, J.W., 2008, Associations between breeding marsh bird abundance and Great Lakes hydrology: Journal of Great Lakes Research, v. 34, p. 351-364.

Tordoff, H.B., 1962, Age and plumage of the black tern: Kansas Ornithological Society Bulletin, v. 13, p. 7-8.

Trautman, M.B., 1939, Twilight flight of the black tern: Wilson Bulletin, v. 51, p. 44-45.

U.S. Fish and Wildlife Service, 1991, Endangered and threatened wildlife and plants; animal candidate review for listing as endangered or threatened species, proposed rule: Federal Register, v. 56, p. 58804-58836.

U.S. Fish and Wildlife Service, 1995, Migratory nongame birds of management concern in the United States: the 1995 list: Office of Migratory Bird Management, U.S. Fish and Wildlife Service, Washington, D.C.

U.S. Fish and Wildlife Service, 1996, Endangered and threatened wildlife and plants; review of plant and animal taxa that are candidates for listing as endangered or threatened: Federal Register, v. 61, p. 7596-7693.

VanRees-Siewert, K.L., 1993, The influence of wetland age on bird and aquatic macroinvertebrate use of restored Iowa wetlands: Unpublished M.S. Thesis, Iowa State University, Ames, Iowa.

VanRees-Siewert, K.L., and Dinsmore, J.J., 1996, Influence of wetland age on bird use of restored wetlands in Iowa: Wetlands, v. 16, p. 577-582.

van Rossem, A.J., 1923, A study of some plumages of the black tern: Condor, v. 25, p. 208-213.

van Rossem, A.J., 1933, Terns as destroyers of birds’ eggs: Condor, v. 35, p. 49-51.

Welham, C.V.J., and Ydenberg, R.C., 1993, Efficiency-maximizing flight speeds of parent black terns: Ecology, v. 74, p. 1893-1901.

Weller, M.W., 1979, Birds of some Iowa wetlands in relation to concepts of faunal preservation: Proceedings of the Iowa Academy of Science, v. 86, p. 81-88.

Weller, M.W., and Spatcher, C.S., 1965, Role of habitat in the distribution and abundance of marsh birds: Special report 43, Agricultural and Home Economics Experimental Station, Iowa State University, Ames, Iowa.

Weseloh, D.V.C., Rodrigue, J., Blokpoel, H., and Ewins, P.J., 1997, Contaminant concentrations in eggs of black terns (Chlidonias niger) from southern Ontario and southern Quebec, 1989-1996: Colonial Waterbirds, v. 20, p. 604-616.

Whitt, M.B., Prince, H.H., and Cox, R.R., Jr., 1999, Avian use of purple loosestrife dominated habitat relative to other vegetation types in Lake Huron Wetland Complex: Wilson Bulletin, v. 111, p. 105114.

Wilkie, J., 1956, Fish eating a black tern: Flicker, v. 28, p. 160.

Williams, S.O., III, 1983, Distribution and migration of the black tern in Mexico: Condor, v. 85, p. 376378.

Zimmerman, A.L., Dechant, J.A., Johnson, D.H., Goldade, C.M., Jamison, B.E., and Euliss, B.R., 2002, Effects of management practices on wetland birds: black tern: Northern Prairie Wildlife Research Center, Jamestown, North Dakota. Available online http://www.npwrc.usgs.gov/resource/literatr/wetbird/blte/blte.htm (Version 30SEP2002). 


\section{Short-eared Owl (Asio flammeus)}

\section{Introduction}

The short-eared owl (Asio flammeus) is one of the world's most widely distributed owls (Holt and others, 2006). This owl is an open country, ground-nesting species that inhabits marshes, grasslands, and tundra throughout most of North America and Eurasia. It also breeds in South American grasslands and on islands such as Iceland, the Hawaiian chain, and the Galapagos. These far-ranging owls are prone to nomadic wanderings as well, which has resulted in far-flung island populations and occasional sightings of these owls on ships at sea (Gray, 1945). In Colorado, short-eared owls range over a variety of open habitats including grasslands, marsh

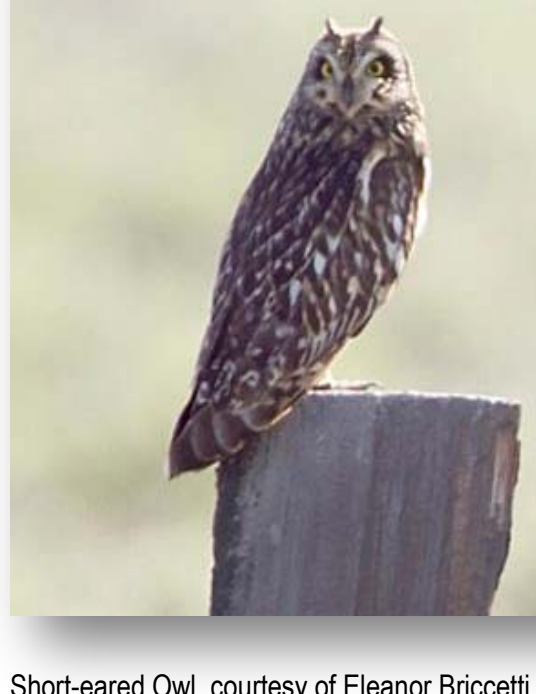

Short-eared Owl, courtesy of Eleanor Briccetti. edges, shrub-steppes, and agricultural lands (Holt and Leasure, 1993). Reproduction and population dynamics of this species are closely linked to the density of its primary prey, small mammals such as Microtus (voles) (Wiggins and others, 2006). Like other birds that depend on such a fluctuating food source, the short-eared owl shows considerable local variation in numbers and reproductive success. Although the literature on its diet in the nonbreeding season is extensive, few studies have thoroughly addressed other facets of its biology, ecology, and life history. This owl is active both day and night and it tends to hunt low above the ground. It generally uses acoustical cues to locate prey, but it also can rely on vision as well.

Historical references generally portray short-eared owls as common breeders on the Great Plains (Cadman and Page, 1994). They were the most common raptor noted during explorations of the Dakotas in the late 1800s (Allen, 1875). In Kansas, they were noted as common in the late 1800s (Goss, 1886). Although such references must be interpreted with caution due to the possibility of observations made during years of peak owl abundance, the general picture drawn from studies on the northern Great Plains is that short-eared owls were formerly a common species. In recent decades, the numbers of short-eared owls have declined in many areas of North America, especially the northeastern United States (Wiggins and others, 2006). The major cause appears to be habitat loss owing to human activities. It could also be susceptible to increased levels of predation because of ground-nesting. Although this species is listed as a Bird of Conservation concern by the USFWS both nationally and within Regions 3, 4, 5, and 6, as well as a priority species within many state and regional Partners in Flight bird conservation plans, no research programs on the conservation status of short-eared owls are currently underway (Wiggins, 2004). The USDA Forest Service (USFS) Region 2 (Rocky Mountain Region) classifies the short-eared owl as a sensitive species. The species is listed as a Priority Species in wetlands in both the Colorado and Wyoming Partners in Flight (PIF) plans (Beidleman, 2000; Cervoski and others, 2001).

A simple Google search on the Internet for "Asio flammeus" revealed 294,000 results and a Google Scholar search provided 4,320 results (accessed 11 July 2011). "Short-eared owl” revealed 493,000 results through Google and 6,070 results through Google Scholar (accessed 11 July 2011). 


\section{Natural History}

\section{Morphology \& Systematics}

The short-eared owl is medium-sized $(33-43 \mathrm{~cm})$ with females about 20 percent larger than males (Wiggins and others, 2006). The adult plumage is dorsally mottled brown and buff and resembles dried grasses. Ventrally, it is whitish to rust-colored with dense vertical streaking on the breast, thinning out on the sides and flanks. The short-eared owl is morphologically similar to the long-eared owl (Asio otus), but is larger overall and multilocus protein electrophoresis indicates a large genetic distance between the two species (Randi and others, 1991). These two species are usually separated by diel activity period, with the long-eared owl being primarily nocturnal and the short-eared owl more crepuscular (Wiggins and others, 2006).

Ten subspecies of short-eared owls are recognized following Holt and others (1999) and Dickinson (2003). Two of these subspecies occur in North America, one breeding and another only a visitor to southern Florida. A. f. flammeus (Pontoppidan, 1763) is the subspecies that breeds across North America, Europe, northern Africa, and northern Asia.

\section{Migration}

In cooler parts of their range, including Colorado, short-eared owls migrate seasonally, and Colorado hosts more birds in winter than in summer. Sclater (1912) characterized this species as a winter visitor, and several later publications also mentioned short-eared owls only as winter visitors and transients (for example, Aiken and Warren, 1914, Niedrach and Rockwell, 1939). The species is considered a partial migrant but is thought to show more long-distance migrations in the northern part of its range (Wiggins and others, 2006). Although present year-round at mid-latitudes, USFWS band data indicate seasonal north/south migration and west/southwest movements for such individuals (Clark, 1975). Migrants and nomads may flock in large numbers in response to concentrations of, or changes in, prey populations (Bent, 1938). For example, 60 owls seen at Monte Vista NWR in mid-August 1958 probably represented a post-breeding flock (Boyle, 1998).

\section{Habitat}

The short-eared owl is almost always associated with open country that supports small mammals (voles, lemmings), typically in large expanses of prairie and coastal grasslands, heathlands, shrubsteppe, and tundra. However, the species also uses agricultural areas. The Breeding Bird Atlas of Colorado recorded short-eared owls most often in grasslands, prairies, and wetlands (68 percent of habitat observations), less commonly in shrublands, and rarely in scrub oak or pinyon-juniper woodlands (Boyle, 1998).

On the Great Plains, short-eared owls prefer to nest within large patches of relatively tall (30 to $60 \mathrm{~cm}$ ), dense, ungrazed grassland (Duebbert and Lokemon, 1977; Fondell and Ball, 2004). In Illinois, Herkert and others (1999) in Illinois found that the owls required relatively short grass ( $<50 \mathrm{~cm}$ tall) and most grasslands in the region needed to be mowed or burned to maintain this condition. Nests on the arctic plain typically are on elevated patches of tundra vegetation (Pitelka and others, 1955a). At Churchill, Manitoba, they often nest at the base of small birch or willow (Jehl, 2004). In coastal Massachusetts, short-eared owls nest in grassy dune vegetation (Holt, 1992). In Cuba, short-eared owls were found nesting in pasturelands, rice fields, and sugar-cane plantations (Garrido, 1984). In Hispaniola, one nest was found in an abandoned agricultural field, below a small bush (Guerrero, 2005). This species also will nest on slight ridges and mounds if present. 
During the nonbreeding season, short-eared owls use habitats similar to those used during the breeding season, but may also use large open areas within woodlots, stubble fields, fresh and saltwater marshes, weedy fields, dumps, gravel pits, rock quarries, and shrub thickets (Clark, 1975). In Missouri, the short-eared owl prefers dense grasslands less than $30 \mathrm{~cm}$ high (Weller and others, 1955).

Occasionally, this species will roost in trees during the winter (Clark, 1975; Bosakowski, 1986). Winter areas often turn into breeding areas if food is plentiful (Clark, 1975). In coastal southeastern Massachusetts, short-eared owls hunt in salt marshes and the edges of salt marshes, where grass transitions to low brush (Iva sp.). They also have been documented foraging in open pastures and fields with low woody vegetation (Rosa, Prunus sp.) (Wiggins and others, 2006).

\section{Foraging Habits}

Small mammals, particularly Microtus, are the main foods taken by short-eared owls (Craighead and Craighead, 1956; Clark, 1975; Colvin and Spaulding, 1983; Holt, 1993a; 1993b; Wiggins and others, 2006). Less frequently, this species will hunt birds. There is a strong positive correlation between vole abundance and owl abundance in several areas of this species' distribution, including Scotland (Village, 1987) and Finland (Korpimaki and Nordahl, 1991). Short-eared owls hunt day and night, probably dictated by hunger, prey density, and nestlings' hunger. Winter birds, however, may be essentially crepuscular (Clark, 1975). Erinaro (1973) reported that diel activity of short-eared owls coincided with activity periods of prey. The extent of diurnal foraging may be over emphasized, facultative, or due to the ease in which this owl is observed in open habitats (Wiggins and others, 2006). Short-eared owls hunt primarily on the wing, approximately 0.3 to $3.0 \mathrm{~m}$ above ground (Clark, 1975; Village, 1987). They also hover 2-30 m above ground or, less frequently, perch on poles or hills. They forage similarly to northern harriers (Circus cyaeneus) and can quickly adjust flight to drop down on prey.

\section{Breeding}

Male short-eared owls may begin courtship displays during late winter and continue into the nesting stage (Pitelka and others, 1955a; Hammerstrom and others, 1961; Clark, 1975). Pair formation begins in mid-February and continues through June (Urner, 1923; 1925; DuBois, 1924; Pitelka, 1955b; Hammerstrom and others, 1961; Beske and Champion, 1971; Trann, 1974; Clark, 1975; Holt, 1992). Communal winter roosts may turn into local breeding territories (Clark, 1975; Wilson, 1995). Shorteared owls are thought to be colonial nesters, but coloniality is probably dependent on prey, nesting cover, and area. The first brood of the season occasionally appears as early as late March, but more often in April through June (Pitelka, 1955b). This species is reported to produce two broods in a season, but more data are needed on marked individuals to confirm this (Mikkola, 1983).

One of the only owls to build their own nests, female short-eared owls make a shallow scrape on the ground and usually construct a sizable nest of grass blades, forbs, and downy feathers (Clark, 1975; Holt and Leasure, 1993). Owls may transport vegetation from some distance, making it possible to confirm breeding by observing them carrying nest materials. Because ground-nesting makes females and young vulnerable to predation, incubating females often sit tight until intruders approach very closely, making nests hard to find by flushing nesting females. Young are more precocial than those of most other owls; they gain weight rapidly and often leave the nest on foot when only 14-17 days old, well before fledging.

The Colorado Breeding Bird Atlas verified previous reports that short-eared owls are scarce and local breeders in Colorado (Boyle, 1998). Breeding populations occur in North Park, the SLV, and the northern Great Plains (Boyle, 1998). 


\section{Demography \& Populations}

Short-eared owls may lay large clutches in response to the abundance of prey in the nesting area. Thus, the reproductive potential of this species is high (Wiggins, 2004). Although available data suggest that pre-fledging survival is relatively high for a ground-nesting species, there is little information on post-fledging survival. No study has measured adult or juvenile survival rates for short-eared owls. North American Bird Banding Laboratory recovery records are limited ( $n=47)$, but the longevity record for a wild short-eared owl is 4 years, 2 months in the United States (Wiggins and others, 2006). In Europe, the longevity record is 12 years, 9 months for a wild bird (Cramp, 1985).

Population status for this species is difficult to assess because individuals are nomadic and prone to annual fluctuations in numbers. Consequently, fixed-area census projects such as the Breeding Bird Survey (BBS) do not adequately sample for short-eared owls (Wiggins, 2004). An abundance map generated from BBS data shows low abundance ( $<1$ per route) over most of the breeding range (Wiggins and others, 2006). Numbers fluctuated between 0 (in 3 years) and one pair (in 2 years), with a peak of 28 pairs during a year when the lemming population was high (Pitelka and others, 1955a). In southeastern Massachusetts, 1985 estimates showed a total of 20-25 pairs breeding annually on islands off the coast (Holt, 1986a). Christmas Bird Count totals for wintering populations in New Jersey, 19761997, show numbers fluctuating on 4-year cycles (likely reflecting prey cycles farther north), with highs statewide of about 80 individuals and lows <20 (Walsh and others, 1999). In Lowland Mainland, British Columbia, Christmas Bird Count numbers from 1972-1987 ranged from 170 to 5 individuals, often in the space of just a year or two (Campbell and others, 1990).

Historically (1960s-early 1980s), of 7 North American regions, three (Central Southern, Prairie Provinces, Middle Pacific Coast) reported that short-eared owls were greatly down in numbers (Tate, 1986). Declines were also noted in the Midwest, California, and southern Ontario (Tate, 1992). Melvin and others (1989) considered this owl to be the rarest and most threatened species of owl in the northeastern United States. The BBS regional trend analysis for short-eared owls along 19 Colorado routes from 1966 to 1999 showed a positive trend estimate of $5.3(-2.7,19.0$; 95 percent CI) (Sauer and others, 2011). From 1999 to 2009, the trend was also positive and estimated to be 14.3 (-9.4, 72.1 ; 95 percent CI). However, the regional credibility measure for this species was the category "red," meaning that data were deficient because of overall low abundances per route and/or the results were too imprecise to detect long-term trends.

\section{Threats}

Data are limited on causes of death of short-eared owls in North America, but occasionally the birds are hit by cars and airplanes, shot, or trapped (Clark, 1975; Holt, 1992). They may also suffer from collisions with barbed-wire fences, but the extent of this problem is unknown (Wiggins and others, 2006). A road-killed bird in England was found be infected with Tuberculosis (Mycobacterium tuberculosis avium; Harrison, 1943). In California, secondary poisoning from fowl cholera (Pasteurella bacteria) passed through waterfowl, rodents, and raptors, killing 44 short-eared owls (Rosen and Morse, 1959). Single cases of mortality due to the West Nile Virus in the midwestern United States (Fitzgerald and others, 2003) and avian cholera (Pasteucella multocida) in the Texas panhandle (Taylor and Pence, 1981) have been reported.

Short-eared owls generally show low concentrations of pesticides and contaminants with little effect on egg viability (such as eggshell thickness and breakage, tissue damage, or embryo mortality) or health of adults. Mean levels of DDE in 5 short-eared owl eggs from the Canadian prairies in the 1960s was 0.5 ppm (Keith and Gruchy, 1972). Although organochlorine residues magnify with successive trophic levels in the food chain, birds of prey (such as short-eared owls) that eat mostly herbivorous 
mammals usually accumulate low levels of the compounds. There is some evidence that short-eared owls are susceptible to organophosphate contamination. In Israel, five short-eared owls were found dead and four were paralyzed in a field sprayed with Azodrin (an organophosphate) to control a vole outbreak (Mendelssohn and Paz, 1977).

Nesting habits and nomadism make this species particularly vulnerable to habitat loss during any season (Wiggins and others, 2006). Habitat loss includes conversion of open habitats to agriculture, grazing, recreation, housing, and resort development. Reforestation in some areas may also contribute to habitat loss. Predation by striped skunks (Mephitis mephitis) on eggs and nestlings was suspected in the decline of short-eared owls on Martha’s Vineyard Island, Massachusetts (Melvin and others, 1989) and disturbance of nests by domestic and feral cats and dogs is known (Tate, 1992). Interspecific competition with barn owls (Tyto alba) may also occur; successful nest box programs to attract barn owls have coincided with the decline of the short-eared owl on Martha's Vineyard and Nantucket islands, Massachusetts.

Short-eared owls appear to be particularly sensitive to habitat fragmentation as they require relatively large tracts of grassland and are ground nesters, making them susceptible to the increased predation pressure that is typical within fragmented landscapes near rural developments. The development of conservation/management plans for this owl has been hampered by the difficulty in accurately assessing their local and regional status, and by a lack of information on reproductive success. The loss of open grassland habitats on the Great Plains and along the Pacific and northern Atlantic coasts has been cited in a number of studies as the primary causative factor behind population declines. On the Great Plains, the primary source of habitat loss has been the conversion of native prairie to agriculture and overgrazing of remaining grasslands (Wiggins and others, 2006). Along coastal areas, which includes many wintering sites, recreational use and land development have caused losses of nearshore marsh and oldfield habitats.

Wiggins (2004) summarized the current and historical threats to the viability of short-eared owl populations in the Rocky Mountain region (Region 2, USFS) and ranked the threats as follows:

- Loss of native grassland and wetland habitat - This has been a problem historically, but recent efforts (for example, Playa Lakes Joint Venture, Conservation Reserve Program [CRP]) may be slowing habitat loss. However, the extent to which CRP land represents suitable breeding habitat for short-eared owls is still unclear.

- Degradation of existing grasslands due to overgrazing by livestock - This represents a continuing problem on most land in the Rocky Mountain region. Efforts to reduce or to eliminate grazing would clearly benefit short-eared owls.

- Degradation of grassland habitat due to fragmentation - As short-eared owls require large (minimum $100 \mathrm{ha}$ ) tracts of land for successful nesting, fragmentation of grassland habitats has likely had significant negative impacts on populations in the Rocky Mountain region.

\section{Management}

\section{Response to Management}

Although disturbance generally has a negative effect on short-eared owls, periodic disturbances may be necessary to maintain suitable habitat. In tallgrass areas, burning or mowing every 3-5 years is recommended to maintain habitat for voles, the principal small rodent prey of short-eared owls (Lemen and Clausen, 1984; Kaufman and others, 1990). Berkey and others (1993) suggested that dense nesting cover in uplands could be hayed periodically to stimulate plant growth. In Illinois, short-eared owls preferred rotary-mowed grasslands that were $30-40 \mathrm{~cm}$ tall to idle grasslands with taller vegetation 
(Herkert and others, 1999). In tallgrass areas, mowing or other techniques are recommended to reduce grass heights. In Missouri, short-eared owls preferred medium to tall grasslands that were moderately grazed or idle (Skinner and others, 1984). Bock and others (1993) suggested that short-eared owls respond negatively to grazing in the Great Plains and western shrubsteppe. In North Dakota, short-eared owls used upland sites with tall, dense vegetation and 2- to 8-year accumulations of residual vegetation (Duebbert and Lokemoen, 1977). Kantrud and Higgins (1992) found short-eared owls nesting in both idle native and seeded grasslands in North Dakota. Fields idled during the current growing season had more nests than fields under long-term grazing; no nests were found in fields grazed during the breeding season (Kantrud and Higgins, 1992). Data from 12 years of nesting studies on annually grazed grasslands indicated that short-eared owls (along with American bitterns and marsh hawks) did not use grazed habitats for nesting (Kirsch and others, 1978). Johnson and Horn (2008) examined the effects of rotational grazing on rodents and raptors in a coastal grassland in northwestern California. They found that grazing reduced short-eared owl activity and this response was presumably driven by changes in the availability of rodent prey, not by a direct response to the presence of cattle.

The impact of prescribed burning on ground-nesting birds was investigated in northwestern North Dakota (Kruse and Piehl, 1986). Prescribed burns occurred in 1982 and 1984 and 69 percent of the active clutches survived the fire and 37 percent eventually hatched. One short-eared owl nest was active during the fire, but no new nests were initiated after the fire. Although it is generally not considered good management practice to prescribe fires during the breeding season, burning an area during the nesting season does not necessarily eliminate total production of ground-nesting birds for the year. Kruse and Piehl (1986) suggested that land managers who burn during the nesting season and are concerned about ground-nesting birds should consider partial burns as a management tool. Partial burns will probably have less impact on total vegetation changes, but should result in higher recruitment of birds than would complete burns.

\section{Recommendations}

Management actions for short-eared owls should be focused on protecting large open spaces for hunting, and maintenance of nesting cover in grasslands and shrublands. The Colorado Partners in Flight Bird Conservation Plan suggested that conservation efforts should focus on landscapes of prairie with suitable habitat for short-eared owls and should assure that large areas of this habitat are available (Beidleman, 2000). Beidleman (2000) also suggested that the best locations for this approach in Colorado would be in North Park and the San Luis Valley (SLV). Habitat management schemes for nesting waterfowl and upland gamebirds generally benefit short-eared owls (Beidleman, 2000). Populations of the principal prey species (voles) should be maintained at levels compatible with economic activities on the land. Habitat restoration programs, such as the Conservation and Wetland Reserve Programs, have shown some success in restoring suitable habitat for short-eared owls on private land. Such programs not only provide suitable nesting and wintering habitat, but they may also help to restore small mammal populations, which are the key resource responsible for the population fluctuations of this owl.

In Massachusetts (Massachusetts Natural Heritage Program), management suggestions have included a standardized survey protocol, maintaining large continuous tracks of habitat for owls and their prey, monitoring predation and human disturbance, public education, and research. The short-eared owl has benefitted indirectly from protection of nesting cover for waterfowl (Larsen, 1987). It has also benefitted from reclaimed and replanted strip-mines and dikelands (Tate, 1992). Burning and maintenance of grasslands for gallinaceous birds and waterfowl provides nesting and foraging cover for this owl (Millsap and others, 1987). 
Wiggins (2004) suggested the following management approach for short-eared owls in the Rocky Mountain region:

- Improving existing grassland/wetland quality by limiting livestock grazing to achieve a balanced mix of short/medium/tall grass heights. Eliminating or restricting livestock grazing during the owl breeding season (April through July) on known or potential breeding plots.

- Pursuing habitat conservation measures that will increase the amount of native grassland and wetland habitats, particularly on private land holdings.

- Supporting a research program that would monitor the reproductive success of short-eared owls within the region, relative to the success of owls nesting on other land management types.

Dechant and others (2003) made the following management recommendations for the shorteared owl:

- $\quad$ Create and protect large open areas for short-eared owls and their prey (Holt and Leasure 1993). Because short-eared owls are nomadic, they may be present only sporadically, but suitable habitat should be maintained (Clark 1975, Holt and Leasure 1993).

- Preserve native grassland. Collaborate with ranching and farming advocates to maintain native pasture and rangeland (Johnson 1996). Maintain a mosaic of grasslands and wetlands so that some units are available for nesting, while others are being treated to halt succession (Ryan 1990, Murphy 1993).

- Protect grasslands through conservation easements, land purchases, and development of farm programs with wildlife habitat conservation priorities (Johnson 1996). Continue the Conservation Reserve Program to preserve nesting habitat (Sinclair 1990, Murphy 1991, Bock et al. 1993).

- In North Dakota, periodically burn, mow, or graze, to maintain the 2-8 yr old accumulations of residual vegetation preferred by short-eared owls in this region (Duebbert and Lokemoen 1977, Berkey et al. 1993, Murphy 1993). In tallgrass areas, burning, mowing, or grazing every 2-5 yr is recommended to maintain habitat for small mammal prey (Leman and Clausen 1984, Kaufman et al. 1990). In Illinois, burn, mow, or use other techniques to reduce grass height and maintain vegetation 30-40 cm tall (Herkert et al. 1999).

- Increase the amount of western public rangeland from which livestock are excluded, especially in the U. S. Forest Service National Grasslands (Bock et al. 1993).

- To prevent mortality or injury from collisions with fences, remove unused fences (Fitzner 1975). Increase visibility of fences by hanging pieces of ribbon or foil.

\section{Research Priorities}

One of the areas in the United States where short-eared owls appear to breed regularly is at Monte Vista NWR (Wiggins, 2004). Such a breeding population may allow for a study of a number of problems that are not possible to study elsewhere, including long-term changes in the number of breeding pairs, as well as responses to various management activities (for example, grazing, prescribed fire, and water regulation). The apparently higher site fidelity in such areas could be used to study two important demographic parameters: survival and philopatry (Wiggins, 2004). Although this species is nomadic, the extent to which local habitat characteristics (for example, availability of different grassland successional stages) influence site fidelity deserves further research. Holt and Leasure (1993) suggested that noncyclic, insular vole populations on offshore Massachusetts islands resulted in greater population stability and higher philopatry there. Thus, it is possible that habitat management programs (for example, wetland inundation schemes, prescribed fire) carried out on National Wildlife Refuges 
may be providing an optimal mosaic of grassland/wetland cover for short-eared owls, which in turn may be responsible for the higher frequency of breeding activity in those areas (Wiggins, 2004). Studies that involved individually marking males and females could also provide conclusive evidence of the extent of site fidelity at breeding and wintering sites. Wiggins (2004) also suggested that detailed, long-term studies of site occupancy and owl reproductive success would be useful as well as studies of how habitat fragmentation effects occupancy and reproductive success. Wiggins (2004) also suggested that a quantitative study of foraging habitat choice, in summer and winter, would provide useful information for the conservation of short-eared owls in the Rocky Mountain region.

\section{Bibliography}

Able, K., 1990, Species summary: Kingbird, v. 40, p. 118.

Aiken, C.E.H., and Warren, E.R., 1914, The birds of El Paso County, Colorado, II: Science Series, Volume 12, Number 13, Colorado College, Colorado Springs, Colorado.

Allen, J.A., 1875, Notes on the natural history of portions of Dakota and Montana territories, being the substance of a report to the Secretary of War on the collections made by the North Pacific Railroad Expedition of 1873, Gen. D.S. Stanley, Commander: Proceedings of the Boston Society of Natural History, v. 17, p. 33-86.

American Ornithologists' Union, 1983, Check-list of North American birds, $6^{\text {th }}$ edition: American Ornithologists’ Union, Washington, D.C.

Andrews, R., and Righter, R., 1992, Colorado birds: a reference to their distribution and habitat: Denver Museum of Natural History, Denver, Colorado.

Andrle, R.F., and Carroll, J.R., 1988, The atlas of breeding in New York State: Cornell University Press, Ithaca, New York.

Austin, J.E., and Pyle, W.H., 2004, Nesting ecology of waterbirds at Grays Lake, Idaho: Western North American Naturalist, v. 64, p. 277-292.

Baicich, P.J., and Harrison, C.J.O., 1997, A guide to the nests, eggs, and nestlings of North American birds, $2^{\text {nd }}$ edition: Academic Press.

Baker, J.A., and Brooks, R.J., 1981, Raptor and vole populations at an airport: Journal of Wildlife Management, v. 45, p. 390-396.

Banfield, A.W.F., 1947, A study of the winter feeding habits of the short-eared owl in the Toronto region: Canadian Journal of Research, v. 25, p. 45-65.

Barringer, J.N., 1980, Unusual plumaged short-eared owl: Loon, v. 52, p. 92.

Beidleman, C.A., 2000, Colorado Partners in Flight Land Bird Conservation Plan: Version 1.0, Estes Park, Colorado. Online at http://www.blm.gov/wildlife/plan/pl-co-10.pdf. Accessed 1 July 2011.

Belanger, L., and Bombardier, M., 1996, Short-eared owl: Pp. 610-613 in Gauthier, J., and Aubrey, Y., eds., The Breeding Birds of Quebec: Atlas of the Breeding Birds of Southern Quebec: Association quebecoise des groups d' ornithologues, Province of the Quebec Society for the Protection of Birds, Canadian Wildlife Service, Environment Canada, Quebec Region, Montreal.

Bent, A.C., 1938, Life histories of North American birds of prey, part 1: U.S. National Museum Bulletin 170, Washington, D.C.

Beske, A., and Champion, J., 1971, Prolific nesting of short-eared owls in Buena Vista salt marsh: Passenger Pigeon, v. 33, p. 99-103.

Bildstein, K.L., and Ashby, M., 1975, Short-eared owl robs marsh hawk of prey: Auk, v. 92, p. 807-808.

Blem, C.R., Blem, L.B., Felix,, J.M., and Holt, D.W., 1993, Estimation of body mass of voles from crania in short-eared owl pellets: American Midland Naturalist, v. 129, p. 282-287.

Bosakowski, T., 1986, Short-eared owl roosting strategies: American Birds, v. 40, p. 237-240. 
Bosakowski, T., 1989, Observations on the evening departure and activity of wintering short-eared owls in New Jersey: Journal of Raptor Research, v. 23, p. 162-166.

Boyle, S., 1998, Short-eared owl, Asio flammeus: Pp. 226-227 in Kingery, H.E., ed., Colorado Breeding Bird Atlas, Colorado Bird Atlas Partnership, Copublished by Colorado Division of Wildlife, Denver, Colorado.

Brauning, D.W., 1992, Atlas of breeding birds of Pennsylvania: University of Pittsburgh Press, Pittsburgh, Pennsylvania.

Brooks, W.S., 1915, Notes on birds from east Siberia and arctic Alaska: Bulletin of the Museum of Comparative Zoology, v. 59, p. 361-413.

Bryan, W.A., 1903, The short-eared owl (Asio accipitrinus) taken far out at sea: Auk, v. 20, p. 212-213. Burton, J.A., 1984, Owls of the world: Tanager Books, Dover, New Hampshire.

Cadman, M.D., and Page, A.M., 1994, Status report on the short-eared owl Asio flammeus in Canada: Committee on the Status of Endangered Wildlife in Canada, Ottawa, Ontario, Canada.

Calladine, J., Garner, G., Wernham, C., and Buxton, N., 2010, Variation in the diurnal activity of breeding short-eared owls Asio flammeus: implications for their survey and monitoring: Bird Study, v. 57, p. 89-99.

Campbell, R.W., Dawe, N.K., McTaggart-Cowan, I., Cooper, J.M., Kaiser, G.W., and McNall, M.C.E., 1990, The birds of British Columbia, Vol. 2: Royal British Columbia Museum, Victoria.

Carnegie, S.D., Urton, E.J., and Gummer, D.L., 2001, Short-eared owl, Asio flammeus, attack on a burrowing owl, Athene cunicularia, in Suffield National Wildlife Area, Alberta: Canadian FieldNaturalist, v. 115, p. 345.

Carson, R.D., 1962, Courtship behavior of short-eared owl: Blue Jay, v. 20, p. 2-3.

Chitty, D., 1938, A laboratory study of pellet formation in the short-eared owl (Asio flammeus): Proceedings of the Zoological Society, London, v. 108, p. 267-287.

Clark, R.J., 1972, Pellets of the short-eared owl and marsh hawk compared: Journal of Wildlife Management, v. 36, p. 962-964.

Clark, R.J., 1975, A field study of the short-eared owl, Asio flammeus (Pontoppidan), in North America: Wildlife Mongraphs, v. 47, p. 1-67.

Clark, R.J., and Ward, J.G., 1974, Interspecific competition in two species of open country raptors: Circus cyaneus and Asio flammeus: Proceedings of the Pennsylvania Academy of Sciences, v. 48, p. 79-87.

Clarke, J.A., 1983, Moonlight's influence on predator/prey interactions between short-eared owls (Asio flammeus) and deermice (Peromyscus maniculatus): Behavioral and Ecological Sociobiology, v.13, p. 205-209.

Clayton, K.M., 2000, Status of the short-eared owl (Asio flammeus) in Alberta: Alberta Environment, Fisheries and Wildlife Management Division, and Alberta Conservation Association, Wildlife Status Report, No. 28, Edmonton, Alberta, 15 pp. Online at http://www.srd.alberta.ca/BiodiversityStewardship/SpeciesAtRisk/DetailedStatus/documents/seowl.pd $f$. Accessed 1 July 2011.

Colvin, A.B., and Spaulding, S.R., 1983, Winter foraging behavior of short-eared owls in Ohio: American Midland Naturalist, v. 110, p. 124-128.

Condon, A.M., Kershner, E.L., Sullivan, B.L., Cooper, D.M., and Garcelon, D.K., 2005, Spotlight surveys for grassland owls on San Clemente Island, California: Wilson Bulletin, v. 117, p. 177-184. Cooke, W.W., 1897, The birds of Colorado: State Agricultural Collection, 37, Technical Series, 2, Smith-Brooks Printing Company, Denver, Colorado. 
Cooper, M.F., 1998, Short-eared owl, Asio flammeus: Pp. 337-338 in Levine, E., ed., Bull's Birds of New York, Comstock, Ithaca, New York.

Craighead, J.J., and Craighead, F.C., 1956, Hawks, owls and wildlife: Stackpole Company, Harrisburg, Pennsylvania.

Cramp, S., 1985, The birds of the western Palearctic, Vol. 4: Oxford University Press, Oxford, United Kingdom.

Davis, A.H., and Prytherch, R., 1976, Field identification of long-eared and short-eared owls: Breeding Birds, v. 69, p. 281-287.

Dechant, J.A., Sondreal, M.L., Johnson, D.H., Igl, L.D., Goldade, C.M., Nenneman, M.P., and Euliss, B.R., 2003, Effects of management practices on grassland birds: short-eared owl: Northern Prairie Wildlife Research Center, Jamestown, North Dakota, Northern Prairie Wildlife Research Center Online, http://www.npwrc.usgs.gov/resource/literatr/grasbird/seow/seow.htm. (Version 12 DEC 2003).

Dubois, A.D., 1923, The short-eared owl as a foster mother: Auk, v. 40, p. 383-393.

Dubois, A.D., 1924, a nuptial song-flight of the short-eared owl: Auk, v. 41, p. 260-263.

Duebbert, H.F., and Lokemoen, J.T., 1977, Upland nesting of American bitterns, marsh hawks and short-eared owls: Prairie Naturalist, v. 9, p. 33-40.

Duke, G.E., Evanson, O.A., and Jegers, A., 1976, Meal to pellet intervals in 14 species of captive raptors: Comparative Biochemistry and Physiology, v. 53, p. 1-6.

Earhart, C.M., and Johnson, N.K., 1970, Size dimorphism and food habits of North American owls: Condor, v. 72, p. 251-264.

Fisler, G.F., 1960, Changes in the food habits of short-eared owls feeding in a salt marsh: Condor, v. 62, p. 486-487.

Fitzgerald, S.D., Patterson, J.S., Kiupel, M., Simmons, H.A., Grimes, S.D., Sarver, C.F., Fulton, R.M., Steficek, B.A., Cooley, T.M., Massey, J.P., and Sikarskie, J.G., 2003, Clinical and pathologic features of West Nile Virus infection in native North American owls (Family Strigidae): Avian Diseases, v. 47, p. 602-610.

Fondell, T.F., and Ball, I.J., 2004, Density and success of bird nests relative to grazing on western Montana grasslands: Biological Conservation, v. 117, p. 203-213.

Foster, B., 1955, The short-eared owl at Churchill, Manitoba: Ontario Field Biology, v. 9, p. 15-17.

Fulk, G.W., 1976, Owl predation and rodent mortality: Mammalia, v. 40, p. 423-427.

Gallego, A., Baron, M., and Gayoso, M., 1975, Organization of the outer plexiform layer of the diurnal and nocturnal bird retinae: Vision Research, v. 15, p. 1027-1028.

Garrido, O.H., 1984, Asio flammeus (Aves: Strigidae) nesting in Cuba: Caribbean Journal of Science, v. 20, p. 67-68.

Goddard, T.R., 1935a, A census of short-eared owls (Asio flammeus) at Newcastleton, Roxburghshire, 1934: Journal of Animal Ecology, v. 4, p. 113-118.

Goddard, T.R., 1935b, Notes on colour variation and habits of short-eared owls: Breeding Birds, v. 28, p. 290-291.

Goss, N.S., 1886, A revised catalogue of the birds of Kansas: Kansas Publishing House, Topeka, Kansas.

Graber, R.R., 1962, Food and oxygen consumption in three species of owls (Strigidae): Condor, v. 64, p. 473-487.

Grant, P.R., Smith, N.M., Abbott, I.J., and Abbott, L.K., 1975, Finch numbers, owl predation and plant dispersal on Isla Daphne Major, Galapagos: Oecologia, v. 19, p. 239-257. 
Grant, T.A., Madden, E.M., Shaffer, T.L., and Dockens, J.S., 2010, Effects of prescribed fire on vegetation and passerine birds in northern mixed-grass prairie: Journal of Wildlife Management, $\mathrm{v}$. 74, p. 1841-1851.

Gray, J.A., 1945, Land birds at sea: Condor, v. 47, p. 215-216.

Groot, R.S., D., 1983, Origin, status and ecology of the owls of Galapagos: Ardea, v. 71, p. 167-182.

Guerrero, S., 2005, Notes on the reproductive behavior of the Hispaniola short-eared owl (Asio flammeus domingensis) in the wild: Tyto, v. 10, p. 18-21.

Hahn, I., Romer, U., and Schlatter, R.P., 2005, Distribution, habitat use, and abundance of landbird communities on the Juan Fernandez Islands, Chile: Ornitologia Neotropical, v. 16, p. 371-385.

Hall, T.R., Howard, W.E., and Marsh, R.E., 1981, Raptor use of artificial perches: Wildlife Society Bulletin, v. 9, p. 296-298.

Hamerstrom, F., and Berger, D.D., 1961, Nesting of short-eared owls in Wisconsin: Passenger Pigeon, v. 23, p. 46-48.

Harrison, J.G., 1943, On a case of tuberculosis in a wild bird: Ibis, v. 85, p. 516-517.

Hendrickson, G.O., and Swan, C., 1938, Winter notes on the short-eared owl: Ecology, v. 19, p. 584588.

Henshaw, H.W., 1901, Birds of prey as ocean waifs: Auk, v. 18, p. 162-165.

Herkert, J.R., Simpson, S.A., Westermeier, R.L., Esker, T.L., and Walk, J.W., 1999, Response of northern harriers and short-eared owls to grassland management in Illinois: Journal of Wildlife Management, v. 63, p. 517-523.

Hoffman, W., Wolfenden, G.E.K., and P.W., Smith, 1999, Antillean short-eared owls invade southern Florida: Wilson Bulletin, v. 103, p. 303-313.

Hogan, K.M., Hogan, M.L., Gable, J., and Bray, M., 1996, Notes on the diet of short-eared owls (Asio flammeus) in Texas: Journal of Raptor Research, v. 30, p. 102-104.

Holt, D.W., 1985, The short-eared owl in Massachusetts: Cape Naturalist, v. 14, p. 31-35.

Holt, D.W., 1986a, A summary of short-eared owl breeding status in Massachusetts: Bird Observations in Eastern Massachusetts, v. 14, p. 234-237.

Holt, D.W., 1986b, Status report: the short-eared owl in the northeast: Eyas, v. 9, p. 3-5.

Holt, D.W., 1987, Short-eared owl predation on Leach's storm-petrels (Oceanodroma leucorhoa) in Massachusetts: Canadian Field-Naturalist, v. 104, p. 596-597.

Holt, D.W., 1992, Notes on short-eared owl, Asio flammeus, nest sites, reproduction, and territory size in coastal Massachusetts: Canadian Field-Naturalist, v. 106, p. 352-356.

Holt, D.W., 1993a, Breeding season diet of short-eared owls from Massachusetts: Wilson Bulletin, v. 105, p. 490-496.

Holt, D.W., 1993b, Trophic niche of Nearctic short-eared owls: Wilson Bulletin, v. 105, p. 497-503.

Holt, D.W., 1994, Effects of short-eared owls on common tern colony desertion, reproduction, and mortality: Colonial Waterbirds, v. 17, p. 1-6.

Holt, D.W., 2003, Short-eared owl: Pp. 182-183 in Petersen, W.R., and Meservey, W.R., eds., Massachusetts Breeding Bird Atlas, Massachusetts Audubon.

Holt, D.W., and Leasure, S.M., 1993, Short-eared owl (Asio flammeus): American Ornithologists' Union, Washington, D.C.

Holt, D.W., and Melvin, S.M., 1986, Populations dynamics, habitat use, and management needs of the short-eared owl in Massachusetts: summary of 1985 research: Massachusetts Division of Fish and Wildlife, Natural Heritage Program, Boston, Massachusetts. 
Holt, D.W., Berkley, R., Deppe, C., Enriquez-Rocha, P.L., Petersen, J.L., Rangel-Salazar, J.L., Segars, K.P., and Wood, K.L., 1999, Short-eared owl (Strigidae): Pp. 241-242 in del Hoyo, J., Elliott, A., and Sargatal, J., eds., Handbook of birds of the world, Lynx Edicions, Barcelona.

Holt, D.W., Lyon, L.J., and Hale, R., 1987, Techniques for differentiating the pellets of short-eared owls and northern harriers: Condor, v. 89, p. 929-931.

Holt, D.W., Melvin, S.M., and Steele, B., 1992, Nestling growth rates of short-eared owls: Wilson Bulletin, v. 104, p. 326-333.

Howell, S.N.G., and Webb, S., 1995, A guide to the birds of Mexico and northern Central America:

Oxford University Press, Oxford, United Kingdom.

Ingram, C., 1962, Cannibalism by nestling short-eared owls: Auk, v. 79, p. 715.

Jehl, J.R., Jr., 2004, Birdlife of the Churchill Region: status, history, biology: Trafford Publishing, Victoria, British Columbia.

Johnsgard, P.A., 1988, North American owls: biology and natural history: Smithsonian Institution Press, Washington, D.C.

Johnson, M.D., and Horn, C.M., 2008, Effects of rotational grazing on rodents and raptors in a coastal grassland: Western North American Naturalist, v. 68, p. 444-452.

Johnston, R.F., 1956, Predation by short-eared owls on salicornia salt marsh: Wilson Bulletin, v. 68, p. 91-102.

Keith, J.A., and Gruchy, I.M., 1972, Residue levels of chemical pollutants in North American birdlife:

Proceedings of the International Ornithological Congress, v. 15, p. 437-454.

Killpack, M.L., 1951, Short-eared owl eaten by horned owl: Condor, v. 53, p. 262.

Kitchin, E.A., 1919, Nesting of the short-eared owl in western Washington: Condor, v. 21, p. 21-25.

Korpimaki, E., and Norrdahl, K., 1991, Numerical and functional responses of kestrels, short-eared owls, and long-eared owls to vole densities: Ecology, v. 72, p. 814-826.

Kruse, A.D., and Piehl, J.L., 1986, The impact of prescribed burning on ground-nesting birds:

Proceedings of the North American Prairie Conference, v. 9, p. 153-156.

Kumlien, L., 1899, Habits of young short-eared owls: Osprey, v. 3, p. 69-70.

Larsen, J.C., 1987, Short-eared owl breeding survey: Non-game Wildlife, No. W-65-R-4, California Department of Fish and Game.

Leasure, S.M., and Holt, D.W., 1991, Techniques for locating and capturing nesting female short-eared owls (Asio flammeus): North American Bird Bander, v. 16, p. 32-33.

Lein, R., and Boxall, P.C., 1979, Interactions between snowy and short-eared owls in winter: Canadian Field-Naturalist, v. 93, p. 411-414.

Lockie, J.D., 1955, The breeding habits and food of short-eared owls after a vole plague: Bird Study, v. 2, p. 53-67.

Long, C.A., and Wiley, M.L., 1961, Contents of pellets of the short-eared owl, Asio flammeus, in a prairie habitat in Missouri: Transactions of the Kansas Academy of Science, v. 64, p. 153-154.

Marr, T.G., and McWhirter, D.W., 1982, Differential hunting success in a group of short-eared owls: Wilson Bulletin, v. 94, p. 82-83.

Master, L., 1992, Short-eared owl: Pp. 192-193 in Brauning, D., ed., Atlas of breeding birds in Pennsylvania, University of Pittsburgh Press, Pittsburgh, Pennsylvania.

Melvin, S.M., Smith, D.G., Holt, D.W., and Tate, G.R., 1989, Small owls: Pp. 88-96 in Pendleton, B.G., ed., Proceedings of the northeast raptor management symposium and workshop, National Wildlife Federation, Washington, D.C.

Mendelssohn, H., and Paz, U., 1977, Mass mortality of birds of prey caused by Azodrin, an organophosphorus insecticide: Biological Conservation, v. 11, p. 163-170. 
Miller, A.H., 1934, The vocal apparatus of some North American owls: Condor, v. 36, p. 204-213. Millsap, B.A., Kline, K.W., and Giron Pendleton, B.A., 1987, Habitat management: Pp. 215-237 in Pendleton, B.A.G., Millsap, B.A., Kline, K.W., and Bird, D.M., eds., Raptor management techniques manual, National Wildlife Federation Technical Series 10, Washington, D.C.

Mitchell, L.R., Gabrey, S., Marra, P.P., and Erwin, R.M., 2006, Impacts of marsh management on coastal-marsh bird habitats: Studies in Avian Biology, v. 32, p. 155-175.

Moore, F.R., 1977, Flocking behavior and territorial competitors: Animal Behavior, v. 25, p. 10631066.

Munyer, E.A., 1966, Winter food of the short-eared owl: Transactions of the Illinois Academy of Sciences, v. 52, p. 174-180.

Murphy, R.K., 1991, Ecology and management of prairie raptors: Proceedings of the Nongame Wildlife Workshop, U.S. Fish and Wildlife Service, Region 6.

Murphy, R.K., 1993, History, nesting biology, and predation ecology of raptors in the Missouri Coteau of northwestern North Dakota: Unpublished PhD Dissertation, Montana State University, Bozeman, Montana.

Murray, G.A., 1976, Geographic variation in the clutch size of seven owl species: Auk, v. 93, p. 602613.

Niedrach, R.J., and Rockwell, R.B., 1939, The birds of Denver and mountain parks: Colorado Museum of Natural History, Popular series number 5, Denver, Colorado.

Norberg, R.A., 1987, Evolution, structure and ecology of northern forest owls: Pp. 9-23 in Nero, R.W., Clark, R.J., Knapton, R.J., and Hamre, R.H., eds., Biology and conservation of northern forest owls, U.S. Forest Service, GTR-RM 142, Fort Collins, Colorado.

Page, G., and Whitacre, D.F., 1975, Raptor predation on wintering shorebirds: Condor, v. 77, p. 73-83.

Peakall, D.B., and Kemp, A.C., 1980, Organochlorine levels in owls in Canada and South Africa:

Ostrich, v. 51, p. 186-187.

Peters, H.S., 1936, A list of external parasites from birds of the eastern part of the United States: BirdBanding, v. 7, p. 9-27.

Philips, J.R., Poole, A., and Holt, D.W., 1988, Nest mites of ospreys and short-eared owls in Massachusetts salt marshes, USA: Pp. 305-307 in Channabasavanna, G.P., and Viraktamath, C.A., eds., Progress in Acarology, vol. 2, Proceedings of the $7^{\text {th }}$ Acarology Congress, Bangalore, India.

Pitelka, F.A., Tomich, P.Q., and Greichel, G.W., 1955, Breeding behavior of jaegers and owls near Barrow, Alaska: Condor, v. 57, p. 3-18.

Randi, E., Fusco, G., Lorenzini, R., and Spina, F., 1991, Allozyme divergence and phylogenetic relationships within the Strigiformes: Condor, v. 93, p. 295-301.

Rau, J.R., Villagra, M.C., Mora, M.L., Martinez, D.R., and Tilleria, M.S., 1992, Food habits of the short-eared owl (Asio flammeus) in southern South America: Journal of Raptor Research, v. 26, p. 3536.

Sage, J.H., 1883, A partial albino short-eared owl: Bulletin of the Nuttall Ornithological Club, v. 8, p. 183.

Sauer, J.R., Hines, J.E., Fallon, J.E., Pardieck, K.L., Ziolkowski, D.J., Jr., and Link, W.A., 2011, The North American Breeding Bird Survey, Results and Analysis 1966 - 2009: Version 3.23.2011. Online at http://www.mbr-pwrc.usgs.gov/bbs/bbs.html. Accessed on 12 July 2011.

Schneider, K.J., 2003, Status and ecology of the short-eared owl (Asio flammeus) in New York State: Kingbird, v. 53, p. 313-330.

Schulmeister, R.P., 1980, Short-eared owl preys on white terns: Elepaio, v. 41, p. 41.

Sclater, W.H., 1912, A history of the birds of Colorado: Witherby and Co., London, United Kingdom. 
Shaw, G., 1995, Habitat selection by short-eared owls Asio flammeus in young coniferous forests: Bird Study, v. 42, p. 158-164.

Sinclair, P.H., Nixon, W.A., Eckert, C.D., and Hughes, N.L., 2003, Birds of the Yukon Territory: UBC Press, Vancouver, British Columbia.

Small, A., 1994, California birds: status and distribution: Ibis Publishing, Temecula, California.

Snyder, N.F.R., and Wiley, J.W., 1976, Sexual size dimorphism in hawks and owls of North America: Ornithological Monographs No. 20, p. 1-96.

Sooter, C.A., 1942, Duck hawk takes short-eared owl: Condor, v. 44, p. 182.

Stabler, R.M., and Holt, P.A., 1965, Hematozoa from Colorado birds: Falconiformes and Strigiformes: Journal of Parasitology, v. 51, p. 927-928.

Stegeman, L.C., 1957, Winter food of the short-eared owl in central New York: American Midland Naturalist, v. 57, p. 120-124.

Stewart, R.E., 1975, Breeding birds of North Dakota: Tri-College Center for Environmental Studies, Fargo, North Dakota.

Stone, E., Smith, J., and Thornton, P., 1994, Seasonal variation and diet selection from pellet remains of short-eared owls (Asio flammeus) in Wyoming: Great Basin Naturalist, v. 54, p. 191-192.

Stone, W., 1937, Bird studies at Old Cape May: Delaware Valley Ornithological Club, Philadelphia, Pennsylvania.

Tate, G.R., 1992, Short-eared owl (Asio flammeus): Pp. 171-189 in Schneider, K.J., and Pence, D.M., eds., Migratory nongame birds of management concern in the northeast, U.S. Fish and Wildlife Service, Newton Corner, Massachusetts.

Tate, J., Jr., 1986, The blue list for 1986: American Birds, v. 40, p. 227-236.

Tomkins, I.R., 1936, Notes on the winter food of the short-eared owl: Wilson Bulletin, v. 48, p. 77-79.

Trann, K., 1974, Short-eared owls near Edmonton, 1970-1973: Blue Jay, v. 32, p. 148-153.

Urner, C.A., 1923, Notes on the short-eared owl: Auk, v. 40, p. 30-36.

Urner, C.A., 1925, Notes on two ground nesting birds of prey: Auk, v. 42, p. 31-41.

Village, A., 1987, Numbers, territory-size, and turnover of short-eared owls (Asio flammeus) in relation to vole abundance: Ornis Scand., v. 18, p. 198-204.

Voous, K.H., 1988, Owls of the northern hemisphere: M.I.T. Press, Cambridge, Massachusetts.

Walk, J.W., 1998, Winter roost sites of northern harriers and short-eared owls on Illinois grasslands: Journal of Raptor Research, v. 32, p. 116-119.

Walley, W.J., 1982, Weasel skull in short-eared owl pellet: Canadian Field-Naturalist, v. 96, p. 85.

Walsh, J.V.E., Kane, R., and Halliwell, T., 1999, Birds of New Jersey: New Jersey Audubon, New Jersey.

Weir, R.D., 1987, Short-eared owl: Pp. 214-215 in Cadman, M., Eagles, P., and Helleiner, F., eds., Atlas of the Breeding Birds of Ontario, University of Waterloo Press, Ontario, Canada.

Weller, M.W., Adams, I.C., Jr., and Rose, B.J., 1955, Winter roosts of marsh hawks and short-eared owls in central Missouri: Wilson Bulletin, v. 67, p. 189-193.

Wetmore, A., 1928, The short-eared owls of Porto Rico and Hispaniola: Proceedings of the Biological Society of Washington, v. 41, p. 165-166.

Wheeler, P., 2008, Effects of sheep grazing on abundance and predators of field vole (Microtus agrestis) in upland Britain: Agricultural Ecosystems and Environment, v. 123, p. 49-55.

Wiebe, K.L., 1991, Food habits of breeding short-eared owls in southwestern British Columbia: Journal of Raptor Research, v. 25, p. 143-145. 
Wiggins, D.A., 2004, Short-eared owl (Asio flammeus): a technical conservation assessment: [Online], USDA Forest Service, Rocky Mountain Region. Available at http://www.fs.fed.us/r2/projects/scp/assessments/shortearedowl.pdf. Accessed on 10 June 2011.

Wiggins, D.A., Holt, D.W., and Leasure, S.M., 2006, Short-eared owl (Asio flammeus): Poole, A., ed., The birds of North America Online, Ithaca, Cornell Lab of Ornithology, Retrieved from the Birds of North America Online: http://bna.birds.cornell.edu/bna/species/062. Accessed 1 July 2011.

Wijnandts, H., 1984, Ecological energetics of the long-eared owl (Asio otus): Ardea, v. 72, p. 1-92.

Williford, D., and Skoruppa, M.K., 2011, The winter diet of short-eared owls in subtropical Texas: do southern diets provide evidence of opportunism?: Journal of Raptor Research, v. 45, p. 63-70. Wilson, P.W., 1995, Short-eared owls nest unsuccessfully in northeast Oklahoma: Bulletin of the Oklahoma Ornithological Society, v. 28, p. 24-26.

Wood, C.R., 1976, Piratical short-eared owl: Breeding Birds, v. 69, p. 272.

Young, L.S., Crenshaw, J.G., and Crenshaw, L.L., 1988, Food caching by a short-eared owl: Murrelet, v. 69, p. 39. 


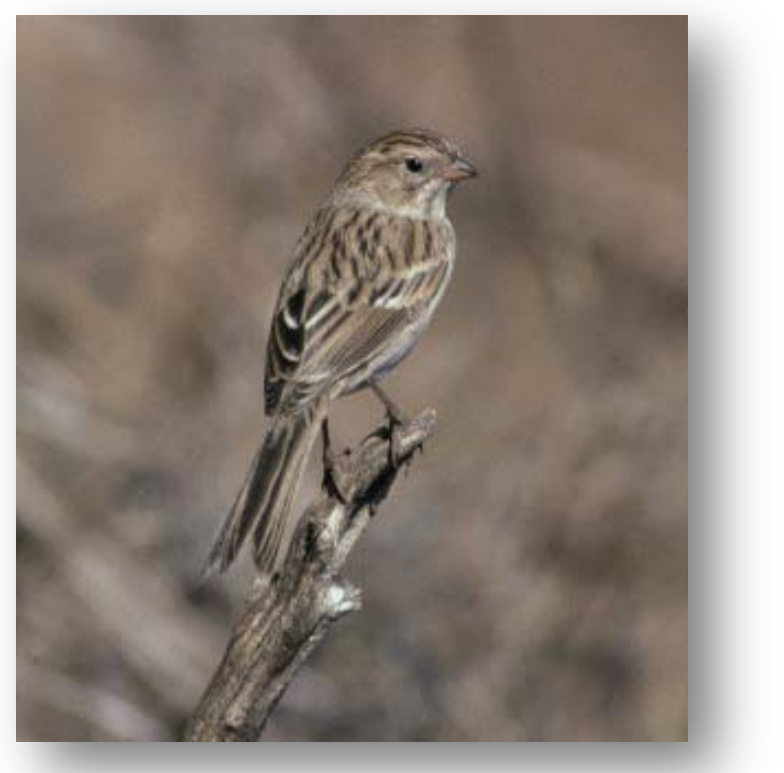

Brewer's Sparrow, courtesy of Dave Menke, U.S. Fish and Wildlife Service.

\section{Brewer's Sparrow (Spizella breweri)}

\section{Introduction}

The Brewer's sparrow (Spizella breweri) is a sagebrush obligate that is often the most abundant songbird in sagebrush shrubsteppe habitats (Holmes and Johnson, 2005). The winter range for the Brewer's sparrow extends from Death Valley to west-central Texas, and south through the western Mexico states of Jalisco and Guanajuato. Their summer range extends into the three western provinces of Canada.

Brewer's sparrow is considered globally "secure" by the Natural Heritage Program because of its wide distribution across North America. According to the Breeding Bird Survey (BBS), however, populations have declined by over 50 percent during the past 25 years. Brewer's sparrow populations within the states of the Rocky Mountain region have exhibited similar long-term declines; in fact, declines in Colorado and Nebraska have outpaced national trends (Holmes and Johnson, 2005). In South Dakota and Kansas, the species is considered of conservation concern by the states' Natural Heritage Programs. The Brewer's sparrow is listed as a priority bird species in the Colorado and Wyoming Partners in Flight Bird Conservation Plans and as a species of special concern by the USFWS. As a result of these regional declines and the species' vulnerability to habitat loss, the U.S. Forest Service Region 2 listed the species as a regional sensitive species.

A simple Google search on the Internet for "Spizella breweri" revealed 36,200 results and a Google Scholar search provided 1,160 results (accessed 11 July 2011). “Brewer’s sparrow” revealed 105,000 results through Google and 1,060 results through Google Scholar (accessed 11 July 2011).

\section{Natural History}

\section{Morphology \& Systematics}

The Brewer's sparrow is a small, slim, long-tailed sparrow with a thin conical bill and a notched tail (Rotenberry and others, 1999). It has a finely streaked brown crown and a median crown-stripe that is frequently absent. The breast is unstreaked as an adult although sometimes the flanks are streaked. There is little or no seasonal change in plumage. There are two recognized subspecies: $S$. $b$. breweri (Brewer's sparrow) and S. b. taverneri (timberline sparrow) (Rotenberry and others, 1999). The timberline sparrow was originally described as a separate species and is recognized as such by some authorities. These subspecies differ in morphology, song, and breeding habitat (Swarth and Brooks, 1925; Oberholser, 1974; Pyle and Howell, 1996; Doyle, 1997). Breeding habitat for Brewer's sparrow is sage scrub or shrubsteppe and breeding habitat for the timberline sparrow is subalpine-alpine transition with low canopy cover (Oberholser, 1974; Doyle, 1997).

\section{Migration}

Brewer's sparrows are Nearctic-Neotropical migrants. Most individuals breed in and around the Great Basin and winter in the Sonoran and Chihuahuan deserts of southwestern United States, western 
Mexico (including Baja California peninsula), and the Mexican Plateau (Rappole and others, 1993). Northerly populations move the farthest south and some southerly populations probably move only a short distance to wintering grounds (Rotenberry and others, 1999). Primary migratory routes are northsouth oriented through the Intermountain West. Brewer's sparrows are early spring migrants: first arrivals on breeding grounds in the Great Basin are in mid- to late March (Paine, 1968). The bulk of migration is in April with some stragglers arriving into late May. Fall migration sometimes begins as early as late July (Paine, 1968), but mid-August through October is more typical (Rotenberry and others, 1999). As with many sparrows, migration is nocturnal (Rotenberry and others, 1999).

\section{Habitat}

Brewer's sparrow (Spizella breweri) is a sagebrush-steppe obligate species (Sauder, 2002). Brewer's sparrows breed in shrublands and the average canopy height is usually $<1.5 \mathrm{~m}$ (Rotenberry and others, 1999). Throughout most of its range in the United States, it is most closely associated with landscapes dominated by big sagebrush (Artemisia tridentata), where it is usually the most abundant bird species (Wiens and Rotenberry, 1981a). The Brewer's sparrow overlaps extensively with the sage sparrow (Amphispiza belli). Brewer's sparrows may also occur in large openings in pinyon-juniper (Pinus edulis - Juniperus spp.) woodlands (Sedgwick, 1987) or large parklands within coniferous forests. In northwestern Canada, this sparrow occurs at high elevation above timberline and in shrubby montane valleys dominated by low-growing willow (Salix spp.), dwarf birch (Betula spp.), and shrubs (Doyle, 1997). Considerable research has been conducted on habitat associations, habitat selection, and density-habitat correlations during the breeding season (for example, Best, 1972; Rotenberry and Wiens, 1980; Wiens and Rotenberry, 1981a; 1985; Larson and Bock, 1986; Rotenberry, 1986; Wiens and others, 1986; 1987a; Petersen and Best, 1987; Knopf and others, 1990; Knick and Rotenberry, 1995).

Sauder (2002) studied factors influencing avian presence and abundance in sagebrush-steppe communities of southeast Idaho. He found that Brewer's sparrow density was significantly correlated with total shrub cover, and capture rates were significantly correlated with shrub cover and dead wood cover. Brewer's sparrows were positively influenced by factors indicating more structurally complex habitat.

Seventy-five percent of the Breeding Bird Atlas confirmations for Colorado occurred in sagebrush (Lambeth, 1998). Ligon (1961) considered Brewer's sparrows to be associated with rabbitbrush and big sage. They have also been found nesting in willow in Colorado (Lambeth, 1998). Habitat characteristics correlated with dense populations of this species include a dominance of shrubs, but little diversity in shrubs, more forbs, less grass, more bare ground, less duff, and relatively level ground with little rockiness (Short, 1984). Breeding Bird Atlas locations for Brewer's sparrow indicate preference for sagebrush of middle heights. Brewer's sparrows usually take the foliage-feeding position, and sage and vesper sparrows, their close associates, forage mostly on the ground (Wiens and others, 1990). After fledging, Brewer's sparrow families often move to higher elevations, mixing with other species, especially chipping sparrows.

\section{Foraging Habits}

The main foods taken by Brewer's sparrows are small insects, mainly gleaned from foliage and bark of shrubs and dwarf trees (Rotenberry and others, 1999). They also eat seeds, which are usually taken from the ground. Brewer's sparrows forage mostly in shrubs ( $>75$ percent of over 600 observation periods) and less commonly on open ground between shrubs or at the base of bunchgrasses (Wiens and others, 1987b). Shrubs selected by foraging sparrows differ significantly from those randomly available; they are larger, more vigorous, and more likely to consist of sagebrush rather than green 
(Chrysothamnus viscidiflora) or gray (C. nauseosus) rabbitbrush (Rotenberry and Wiens, 1998). They intersperse singing with foraging within bouts of foraging and songs are delivered from widely spaced perches (Wiens and others, 1990).

\section{Breeding}

Brewer's sparrows start to arrive in Colorado in mid-April, with full numbers present at the end of the month (Lambeth, 1998). They sing during migration and on the nesting ground, but once paired the birds become quieter (Best and Petersen, 1985). This variable, plus annual fluctuations in nesting schedules due to weather, complicates population monitoring of this species. Increased singing from delayed pairings or failed nesting might falsely indicate relatively high populations. In wetter years, they have larger clutch sizes. Clutch size is typically 3-5 eggs (Harrison, 1979). Brown-headed cowbirds sometimes parasitize this species although there are no records of this in Colorado (Lambeth, 1998). Brewer's sparrows produce replacement clutches and frequently double broods (Rotenberry and others, 1999). Renesting begins soon after the loss of the first nest. Second nests are initiated approximately 10 days after the first brood fledges.

In southeastern Idaho, about 25 percent of color-banded males returned to nesting habitat used in the previous year (Petersen and Best, 1987). Males and females forage together during the first week after pairing; then the females become more secretive during the beginning of the nesting process (Nordin and others, 1988). Compared with surrounding habitat, nests are located in significantly taller, denser shrubs (primarily big sagebrush) with reduced bare ground and herbaceous cover (Petersen and Best, 1985). Available cover may be the primary factor in nest-site selection (Best, 1972). Nests are located toward the edge of the densest portion of sagebrush relative to nests of the sage sparrow and the sage thrasher (Rich, 1980). Brewer's sparrows prefer nest shrubs to be entirely alive or mostly alive (Petersen and Best, 1985). The foliage of live shrubs provides concealment from predators and protection from the elements. Occasionally Brewer's sparrows nest in herbicide-killed shrubs with no foliage but with dense branching and plenty of grass cover (Best, 1972).

\section{Demography \& Populations}

There was significant annual variation in the average number of eggs per clutch at a site in Oregon during a 5-year period (1976-1980; Rotenberry and Wiens, 1989). The increase in clutch size was strongly correlated with increasing precipitation during the preceding winter, implying that Brewer's sparrows respond opportunistically by increasing initial reproductive investment when food is more plentiful (Rotenberry and Wiens, 1991). However, a study in Idaho from 1980 to 1985 found no significant annual variation in clutch size (Petersen and Best, 1987). Proportion of males that successfully acquire mates varies among years and sites (Rotenberry and others, 1999). In Idaho from 1976-1977, only 23 percent of males were successful (Reynolds, 1981). At the same site in 1980-1985, 86 percent were successful (Petersen and Best, 1987). Number of fledglings produced per nest also varies annually and geographically.

In southeastern Idaho, the proportion of banded males returning to the same breeding area from one year to the next was 25 percent (Petersen and Best, 1987). Return rates were comparable for this species in Oregon (Rotenberry and others, 1999). However, these rates represent a lower limit, since they do not account for individuals alive but breeding elsewhere.

Population numbers for this species are highly variable depending on habitat conditions and year (Rotenberry and others, 1999). Although the species is most common in sagebrush-dominated habitats, local densities are not significantly correlated with variation in percent cover of sagebrush. However, densities were observed to decline on plots on which coverage of sagebrush had been reduced, either 
through experimental manipulation or by wildfire (Best, 1972; Schroeder and Sturges, 1975; Castrale, 1982; Kerley and Anderson, 1995). Brewer's sparrow density is usually correlated with some aspect of total shrub cover, or "shrubbiness” (Rotenberry and Wiens, 1980; Wiens and Rotenberry, 1981a; Dobler, 1994; Knick and Rotenberry, 1995).

Population numbers of Brewer's sparrows are negatively influenced by increasing landscapelevel fragmentation of shrublands, and those numbers appear to be more sensitive to variation in landscape-level attributes than in local-scale attributes (Knick and Rotenberry, 1995).

BBS data show the highest abundance for Brewer's sparrows (30-40 individuals per route) in central Nevada northward to southeastern Oregon, with other centers of abundance in southeastern Idaho and southwestern Wyoming (Sauer and others, 1997). The bulk of the breeding population appears to be mostly contiguously distributed. Winter counts show the highest abundance in the United States in southern Arizona, New Mexico, and western Texas (Sauer and others, 1997). There is no information about distribution and abundance in Mexico (Rotenberry and others, 1999) and no density estimates reported for wintering birds.

Brewer's sparrows appear to have undergone statistically significant $(p<0.05)$ declines (from about -3 to -6 percent per year) throughout the BBS survey area during 1966-1996 (Sauer and others, 1997). Surveywide, decline has been -3.7 percent per year. Individual states with significant declines are California (-3.3 percent per year), Idaho (-6.0 percent per year), and Wyoming (-2.8 percent per year). Declines were more pronounced from 1980-1996 than in 1966-1979. No state or physiographic region shows significant upward trends. In contrast, surveywide trends in winter abundance are positive, but not significant (0.2 percent per year). From 1959-1988, there was a significant increase noted in Texas (6.7 percent per year; Sauer and others, 1997).

Although Brewer's sparrows are considered common in western Colorado (Andrews and Righter, 1992), trend estimates show significant decreases from 1966 to 2002 (Sauer and others, 2004). Declines were most pronounced between 1966 and 1979. An analysis of detection frequencies on BBS routes for the periods 1968-1983 and 1983-2001 (Dobkin and Sauder, 2004), indicated detection frequencies on routes in western, southern, and eastern Colorado declined, while in north-central Colorado they increased. The BBS regional trend analysis for Brewer's sparrows along 96 Colorado routes from 1966 to 1999 showed a negative trend estimate of -1.9 (-3.8, 0.4; 95 percent CI) (Sauer and others, 2011). From 1999 to 2009, the trend was also negative and estimated to be -2.0 (-5.2, $1.4 ; 95$ percent CI). The regional credibility measure for this species was the category "blue." A blue category reflects data with at least 14 samples in the long term, of moderate precision, and of moderate abundance on routes.

\section{Threats}

\section{Sources of Mortality}

There are few disease threats reported for Brewer's sparrows. Of four adults examined, two were infected with the blood protozoan Haemoproteus and one with Haemoproteus and Trypanosoma (Greiner and others, 1975). Brewer's sparrows are host to several ectoparasites including biting lice, flesh flies, and blowflies (Rotenberry and others, 1999). Predation of adult Brewer's sparrows by loggerhead shrikes can be a significant source of mortality (Reynolds, 1979; Woods, 1994). Predation by other avian predators (for example, American kestrels, sharp-shinned hawks, and Cooper's hawks) is also a potentially significant cause of mortality. The gopher snake (Pituophis melanoleucus) and the Townsend's ground squirrel (Spermophilus townsendii) are documented predators of eggs and nestling Brewer's sparrows (Holmes and Johnson, 2005). In Oregon, intense, episodic predation of nests was 
attributed to a marked increase in the density of Townsend's ground squirrels. The irruption of ground squirrels appeared to be triggered by a pattern of drought year followed by two relatively wet years, and nest predation peaked when ground squirrels were most abundant (Rotenberry and Wiens, 1989; Rotenberry and others, 1999). Other potential nest predators include the common raven, black-billed magpie, longtailed weasel (Mustela frenata), least chipmunk (Tamius minimus), and snakes other than gopher snakes, such as the western rattlesnake (Crotalus viridis) (Reynolds, 1979; Petersen and Best, 1987; Rotenberry and Wiens, 1989; Rotenberry and others, 1999). These nest predators likely prey on adults as well (Rotenberry and others, 1999). In addition, a coachwhip snake (Masticophis flagellum) has been reported eating adults (Paine, 1968; Rotenberry and others, 1999).

Brewer's sparrow nests are hosts to parasitic brown-headed cowbirds (Molothrus ater) (Holmes and Johnson, 2005). Parasitized nests are usually abandoned by the host during incubation; this desertion usually results in the loss of the entire clutch (Rotenberry and others, 1999). Also, because cowbirds usually remove at least one host egg (Rich, 1978), the number of host young is typically reduced (Rotenberry and others, 1999). The frequency of brood parasitism varies geographically. In southern Idaho, 13 percent of nests were parasitized (Rich, 1978); in southeast Washington, 5 percent (Vander Haegen and Walker, 1999); in central Oregon, 0 percent (Rotenberry and Wiens, 1989); and in southeast Alberta, 52 percent (Biermann and others, 1987). There is no information on the impact of brood parasitism on host productivity at the population level (Rotenberry and others, 1999).

\section{Habitat Loss \& Fragmentation}

Degradation of habitat is the most important threat to Brewer's sparrows (Rotenberry and others, 1999). Large-scale fragmentation and reduction in area of native shrublands has been occurring throughout the Intermountain West (Braun and others, 1976), and may be responsible for declines in Brewer's sparrows reflected in BBS data (Rotenberry, 1998). A conservative estimate suggested that through the mid-1970s, 10 percent of native sagebrush shrublands had been converted to agriculture (Braun and others, 1976). In Colorado, 30 percent of sagebrush was altered between 1900 and 1974 (Braun and others, 1976). In addition to agriculture, a number of other activities have contributed to habitat loss and fragmentation, including urban and suburban development, development of road and powerline rights of way, and range improvement programs that remove sagebrush by burning, herbicide application, and replacing sagebrush with annual grassland to promote forage for livestock (Holmes and Johnson, 2005). The pace of loss has accelerated because of the complex interactions among agriculture, livestock grazing, and invasion of exotic annual plants, especially cheatgrass (Bromus tectorum; Rotenberry, 1998). Brewer's sparrows belong to a group of species that are most typical of undisturbed shrubsteppe; as such, they appear to be especially sensitive to the negative effects of habitat fragmentation (Knick and Rotenberry, 1995a; Rotenberry, 1998). Fragmentation may also reduce sagebrush patch size below a minimum suitable for Brewer's sparrow occupancy (Knick and Rotenberry, 1995a).

Nest predation is probably the principal determinant of reproductive success (Rotenberry and others, 1999), and predation rates are apparently affected by fragmentation of sagebrush shrubsteppe habitat. Predation on artificial and natural nests of shrubsteppe birds was higher in fragmented sites than in continuous shrubsteppe sites in eastern Washington, likely due to an increase in corvid populations associated with agricultural and other human-modified habitats (Holmes and Johnson, 2005). Also, nests might be more difficult to locate in extensive stands of shrubsteppe than in fragmented sites (Vander Haegen and others, 2002). 


\section{Agriculture}

The predominant impact of agricultural development is direct habitat loss due to conversion of shrubland areas to grasslands and croplands, and the subsequent fragmentation of once contiguous shrublands. These losses are long-term and include entire landscapes that are unlikely to be returned to shrublands in the foreseeable future (Dobler and others, 1996; Vander Haegen and others, 2000; Knick and Rotenberry, 2002). In addition to outright habitat loss, agricultural development has a less obvious but destructive role in the introduction and spread of alien plants into natural habitats; this may now be the most serious threat to these habitats in many areas (Rotenberry, 1998). Agricultural areas, and their associated roads, serve as continually renewable sources for immigrant alien plant species (Janzen, 1986; Alberts and others, 1993; Rotenberry, 1998). Furthermore, agricultural areas apparently extend the landscape-level distribution of brown-headed cowbirds, which are avian brood parasites, and corvids such as common ravens and American crows, which can be major predators of songbird nests (Marzluff and others, 1994; Robinson and others, 1995; Rotenberry, 1998; Vander Haegen and others, 2000).

\section{Invasion of Exotic Annual Grasses}

Agricultural development, livestock grazing, off-road vehicle use, and road building disturb soil, which promotes the germination of annual plant seeds and promotes the invasion of exotic annual plants into otherwise undisturbed areas. This process has resulted in perhaps the greatest impact on western shrublands: the establishment of the invasive, exotic cheatgrass (Holmes and Johnson, 2005). Cheatgrass first appeared in the early to mid-1980s, probably as a contaminant in grain seed (Mack, 1981). It then spread into undisturbed shrublands through widespread livestock grazing and the soil surface disturbance. Cheatgrass now occupies millions of hectares of western rangelands, has greatly increased fire frequency, and has substantially, and perhaps permanently, altered postfire successional pathways (Whisenant, 1990; Rotenberry and others, 1999). The principal impact has been to alter the fire ecology of the shrubsteppe ecosystems. Cheatgrass provides a continuous surface cover of relatively fine fuel that carries fire into and over much larger areas than likely occurred historically (Shienant, 1990). It matures and dries earlier than native bunchgrass, increasing the chance of fire earlier in the season (Knick and Rotenberry, 1997). Also, because cheatgrass does not catch and hold snow like a diverse perennial stand of vegetation, the site becomes drier. Shrublands infested with cheatgrass are 20 times more likely to burn than lands without cheatgrass (Stewart and Hull, 1949, Whisenant, 1990).

Although cheatgrass and the increased fire frequency associated with its invasion are threats to sagebrush habitats and the species dependent on them, complete fire suppression also can be a threat to healthy sagebrush ecosystems (Holmes and Johnson, 2005). In some areas, fire suppression and the loss of fine fuels to livestock grazing have resulted in much longer fire-return intervals, which has altered the dominant process (for example, fire) that controlled the shifting temporal and spatial mosaic of grasslands and shrubland characteristic of these landscapes (Dobkin and Sauder, 2004). In Colorado, the ecological integrity of sagebrush shrublands has been widely compromised by the invasion of exotic cheatgrass or native pinyon and juniper plant species (Biedleman, 2000).

\section{Prescribed Fire}

Burning over large areas to eradicate sagebrush is detrimental to Brewer's sparrows because it removes shrub cover, fragments large tracts of sagebrush, and can reduce patch size to levels not used by Brewer's sparrows (Holmes and Johnson, 2005). It also promotes changes in the vegetative community. Although there is some disagreement over the frequency and spatial scale of fires prior to Euro-American settlement, there is uniform agreement that fire frequencies in the Intermountain West 
have been greatly altered over the past 150 years (Dobkin and Sauder, 2004). Altered fire frequencies in combination with the ubiquity of livestock grazing continue to drive the loss of native plant community structure and composition upon which shrubsteppe birds depend.

\section{Mining and Oi//Gas Development}

Energy development and natural resource extraction directly alter sagebrush habitats at the site of operation (Braun and others, 2002; Knick and others, 2003). Associated road networks, pipelines, and power transmission corridors fragment habitat and create soil conditions facilitating the spread of invasive species (Braun, 1998; Gelbard and Belnap, 2003; Knick and others, 2003). The cumulative effects of energy development have not been assessed. However, the density of sagebrush-obligate birds within $100 \mathrm{~m}$ of roads constructed for natural gas development was 50 percent lower than at greater distances (Ingelfinger, 2001; Knick and others, 2003). In addition, the increased numbers of corvids and raptors associated with powerlines also increase the potential impact of predation on sagebrush-breeding birds (Knick and others, 2003). Within the Rocky Mountain region, increasing rates and densities of oil and gas development constitute expanding threats to sagebrush ecosystems. In Wyoming, oil and gas wells have been located primarily in habitats dominated by sagebrush.

\section{Livestock Grazing}

Livestock grazing has affected most of the sagebrush habitats across the range of the Brewer's sparrow. The effects of livestock grazing in shrubland habitats are complex, depending on grazing intensity, season, and duration and the extent of alteration to native vegetation. Livestock grazing impacts sagebrush habitats in several interrelated ways (Holmes and Johnson, 2005). Its greatest impact is soil disturbance that promotes the germination of annual plant seeds and promotes the invasion of exotic annual plants, as previously mentioned. In eastern Washington, Brewer's sparrow abundance was significantly lower at sites with poor range condition (less than 25 percent cover in climax vegetation) than at sites with fair condition (25 to 50 percent cover in climax vegetation), but abundance did not differ between fair and good sites (greater than 50 percent cover in climax vegetation) (Holmes and Johnson, 2005).

\section{Management}

\section{Response to Management}

The influence of management activities and disturbances of Brewer's sparrows habitat have led, in many areas of the West, to large-scale conversion of shrublands to grassland habitats dominated by exotic annuals (Holmes and Johnson, 2005). The conversion of landscapes to exotic annual grasslands with high fire frequencies results in changes in the avian composition from communities composed of mostly shrubland obligates (such as the Brewer's sparrow) to those composed of grassland species (such as meadowlarks [Sturnella spp.] and horned larks [Eremophila alpestris]) (Knick and Rotenberry, 1997). Sagebrush habitat has been found to support more species, have a greater bird density and a greater individual density for most species than cheatgrass habitat types (Schuler and others, 1993). This continuing conversion process will likely result in loss of bird species richness and decreased numbers of shrubland-obligate species, including the Brewer's sparrow (Knick and Rotenberry, 2002).

Holmes (2007) measured songbird abundance and vegetation cover in and around a 420-ha prescribed burn in a mountain big sagebrush community in Oregon. Brewer's sparrows occurred in lower abundance on sites that were largely or completely burned relative to sites that were outside the 
fire perimeter or within unburned islands of shrubs. The number of Brewer's sparrow detections was linearly related to remaining sagebrush cover. Reported responses of Brewer's sparrows to fire are consistently negative (Castrale, 1982; Bock and Bock, 1987; Knick and Rotenberry, 1999; Petersen and Best, 1999; Reinkensmeyer, 2000; McIntyre, 2002; Welch, 2002).

\section{Recommendations}

The overriding essential element for the conservation of Brewer's sparrow is healthy sagebrush shrubsteppe. Nonnative grasses and agricultural and urban conversion now dominate most western shrublands, making it especially important to sustain the remaining native sagebrush communities in a healthy state to support native wildlife, including Brewer's sparrows populations (Paige and Ritter, 1999; Rotenberry and others, 1999). At a regional scale, the maintenance of Brewer's sparrows depends on the existence of extensive tracts of sagebrush shrublands and associated habitat physiognomy, while on a more local scale, the occurrence and abundance of Brewer's sparrows depend on high sagebrush cover, large patch size, habitat heterogeneity, low disturbance, and little fragmentation. The minimum patch size and degree of patch isolation for breeding has not been determined. However, Brewer's sparrows do appear to be area-sensitive, and isolated stands of sagebrush smaller than 2 ha are not likely to be used as nesting habitat (Knick and Rotenberry, 1995a).

\section{Management Approaches}

Holmes and Johnson (2005) suggested the following management approaches:

- The maintenance of the largest, most continuous stands of sagebrush that exist within the SLV complex of Refuges will benefit Brewer's sparrows, as will the maintenance of small openings (for example, $<1 \mathrm{ha}$ ) of short vegetation surrounded by sagebrush (Paige and Ritter, 1999). The first step would be to identify and protect areas of healthy sagebrush shrubsteppe (Holmes and Johnson, 2005). Practices that permanently convert shrublands to nonnative grasslands or agricultural lands should be avoided, as should practices that further fragment areas, such as road-building. The creation of edges with converted habitat should be minimized. Burning to eradicate sagebrush over large areas (for example, >20 to 40 ha) should be avoided, and range fires that threaten to eradicate large areas of sagebrush should be suppressed. Providing for "no net loss of sagebrush habitats” (Paige and Ritter, 1999) across landscapes will help to achieve the desired condition of large areas of healthy sagebrush in a landscape that mimics a natural matrix.

- Disturbed sites should be restored or rehabilitated to native plant communities, if possible. Management should move toward the re-establishment of natural disturbance processes and the careful management of practices, such as livestock grazing, which often degrades sagebrush steppe. In some areas, simply protecting areas from degradation may allow for the reestablishment of native plants. In large undisturbed areas, however, sagebrush and native perennial grasses may need to be reseeded to shorten the recovery time and to prevent dominance by nonnative grasses and forbs. Ecologically appropriate native plant species should be used in all shrubsteppe restoration projects (Knick and others, 2003).

- Sources of soil disturbance (for example, road building, off-road vehicle use, heavy grazing) should be minimized to maintain biological soil crusts, which are sensitive to trampling by humans, vehicles, and livestock (Paige and Ritter, 1999). Roads that fragment otherwise continuous sagebrush should be closed or re-routed. All vehicles should be kept on established roads and trails or confined to areas established specifically for off-road recreation. These areas 
should be established so as not to influence sensitive sagebrush habitats and species.

No single grazing strategy is appropriate for all shrubland habitats, and grazing management should be tailored to the condition and potential of each grazing unit (Paige and Ritter, 1999). Management plans should consider other grazers such as elk and deer, and their influence on the vegetation. Stocking levels should enable the stabilization or increase of native perennial groundcover and reduce disturbance to soil crusts. In addition, grazing seasons and the distribution and types of grazers should be managed to promote native groundcover and to maintain herbaceous cover for nest concealment (Paige and Ritter, 1999). For instance, in stands where cheatgrass and native perennial grasses are mixed, grazing during the dormant period may favor perennial species (Vallentine and Stevens, 1994; Young, 1994; Paige and Ritter, 1999). Managing grazing time and intensity can reduce or eliminate trampling of ground nests and nests in low shrubs, such as Brewer's sparrow nests.

Practices and activities that concentrate livestock, such as corrals, feedlots, and watering sites, during the Brewer's sparrow breeding season may increase the impact of brown-headed cowbird brood parasitism on Brewer's sparrow nesting success (Robinson and others, 1995). Rotating livestock to rest units from cowbird concentrations in alternate years may give local songbird populations breeding opportunities without high parasitism pressure (Paige and Ritter, 1999).

\section{Research Priorities and Information Needs}

Birds can be good indicators of ecosystem health because they tend to have dynamics that parallel those of the ecosystem; they are sensitive enough to provide an early warning of change and to provide continuous assessment over a wide range of stresses. Birds also have dynamics that can be linked to either natural cycles or anthropogenic stressors. In addition, bird populations are distributed over wide geographical areas and/or are often relatively numerous, so they can be accurately estimated, have costs of measurement that are not cost prohibitive, have a low impact to measure, and can provide measurable results that are repeatable with different personnel. Because of the relative ease of detection of songbirds such as the Brewer's sparrow, both individual species and communities can be monitored. Thus, birds can serve as informative organisms for measuring natural and anthropogenic changes and for guiding and measuring management and restoration actions (Greenwood and others, 1993; Hutto, 1998; Hutto and Young, 2002).

Prior to monitoring, an inventory of the biological resource of concern is generally conducted. Bird inventories seek to identify species presence/absence, range, distribution, and relative abundance, and they can provide a baseline for monitoring. Bird monitoring programs are generally developed on this baseline inventory. Commonly, monitoring programs fit into one of two categories: those designed to monitor long-term population trends and those designed to monitor the effects of land management actions. The goals of the monitoring program will affect the methods used. The current Partners in Flight landbird monitoring strategy (Bart and Ralph, 2001) recommends integration of long-term monitoring programs and short-term assessments of habitat associations and land-use effects (Hutto and Young, 2002).

Designing a monitoring program that includes habitat information with sample locations will facilitate the discovery of habitat associations and make a much more effective monitoring program than one based on long-term population trends alone (Hutto and Young, 2002). An integrated approach to monitoring both vital rates and population trends of Brewer's sparrows, and relating them to habitat characteristics across the landscape, is critical for understanding causes of population changes and for identifying, as well as testing, management actions and conservation strategies to reverse population declines (Fancy and Sauer, 2000). Therefore, habitat inventory and habitat monitoring should be 
conducted concomitant with a Brewer's sparrow inventory and monitoring program. Vegetation and habitat should be characterized at multiple spatial scales, and measurements of both horizontal and vertical structure should be taken in areas where sparrows are detected and where they are not. Habitat measurements can be coupled with bird inventories to establish species habitat selection within the area of concern. This information can be used as baseline information in subsequent monitoring of long-term avian population trends, and the effects of land use and management actions.

A review written by experts (Knick and others, 2003) discussed the threats that birds in sagebrush habitats face, synthesized existing information regarding avifauna of sagebrush habitats, and identified their management and conservation needs. They concluded that little is understood regarding shrubsteppe bird-habitat dynamics. To manage and conserve birds in sagebrush habitats there is an urgent need for more research on four major topics:

- Identification of primary land-use practices and their influence on sagebrush habitats and birds,

- Understanding of bird responses to habitat components and disturbance processes of sagebrush ecosystems,

- Hierarchical designs for surveying and monitoring programs, and

- Linking bird movements and population changes during migration and wintering periods to dynamics on sagebrush breeding areas.

This review found that we do not have a comprehensive understanding of how habitat fragmentation influences the productivity, density of breeding adults, size of home range, probability of predation, or brown-headed cowbird parasitism on Brewer's sparrows. The general breeding distribution of the Brewer's sparrow is relatively well known. However, within its geographic distribution, distribution patterns, habitat associations, and demographic information within a range of habitat conditions are not well known. Without information on habitat associations, reproductive success, adult and juvenile survivorship, and dispersal patterns, it is impossible to understand and predict the effects of different management options and conservation actions on source-sink dynamics (Knick and others, 2003). The Brewer's sparrow appears to be an area-dependent species, and studies that improve our knowledge of how landscape context influences Brewer's sparrows' sensitivity to habitat fragmentation, nest predation, and parasitism rates are also needed. Such studies will provide information that can guide conservation planners in determining adequate sizes of sagebrush conservation areas, how these areas should be spatially arranged, and into what type of landscapes they should be placed (Herkert and Knopf, 1998).

In order to study the effects of management approaches on Brewer's sparrows , such as grazing, experiments having strong statistical designs that include treatments and controls at spatial and temporal scales relevant to understanding the impacts to vegetation, soils, and the dynamics of recovery are needed (Knick and others, 2003). Long-term studies incorporating a widespread system of exclosures and the ability to control treatment levels are necessary to measure the effects of land use on habitats and birds. Knick and others (2003) suggest that treatment projects planned by management agencies, and the large number of areas to be treated, represent a tremendous opportunity to design a sound experimental approach. Establishing such studies and combining them with monitoring at appropriate scales would provide the feedback to evaluate treatment effects and provide the basis for adaptive management strategies (Walters, 1986; Morrison, 2002; Knick and others, 2003). Such information is critical for identifying causes of population changes and for testing management actions and conservation strategies to reverse population declines. 


\section{Bibliography}

Alberts, A.C., Richman, A.D., Tran., D., Sauvajot, R., McCalvin, C., and Bolger, D.T., 1993, Effects of habitat fragmentation of native and exotic plants in southern California coastal sage scrub: Pp. 103110 in Keeley, J.E., ed., Interface between ecology and land development in California, Southern California Academy of Sciences, Los Angeles, California.

Andrews, R., and Righter, R., 1992, Colorado birds: a reference to their distribution and habitat: Denver Museum of Natural History, Denver, Colorado.

Bart, J., and Ralph, C.J., 2001, The Partners in Flight landbird monitoring strategy: United States Fish and Wildlife Service, Office of Migratory Bird Management, Washington, D.C.

Best, L.B., 1972, First year effects of sagebrush control on two sparrows: Journal of Wildlife Management, v. 36, p. 534-544.

Best, L.B., and Petersen, K.L., 1985, Seasonal changes in detectability of sage and brewer's sparrows: Condor, v. 87, p. 556-558.

Biedleman, C.A., 2000, Colorado Partners in Flight Land Bird Conservation Plan: Version 1.0, Estes Park, Colorado. Online at http://www.blm.gov/wildlife/plan/pl-co-10.pdf. Accessed 1 July 2011.

Biermann, G.C., McGillivray, W.B., and Nordin, K.E., 1987, The effect of cowbird parasitism on Brewer's sparrow productivity in Alberta: Journal of Field Ornithology, v. 58, p. 350-354.

Block, G., and Morrison, M.L., 2010, Large-scale effects on bird assemblages in desert Grasslands: Western North American Naturalist, v. 70, p. 19-25.

Bock, C.E., and Bock, J.E., 1987, Avian habitat occupancy following fire in a Montana shrubsteppe: Prairie Naturalist, v. 19, p. 153-158.

Bradford, D.F., Franson, S.E., Neale, A.C., Heggem, D.T., Miller, G.R., and Canterbury, G.E., 1998, Bird species assemblages as indicators of biological diversity in Great Basin rangeland:

Environmental Monitoring and Assessment, v. 49, p. 1-22.

Braun, C.E., 1998, Sage-grouse declines in western North America: what are the problems?:

Proceedings of the Western Association of State Fish and Wildlife Agencies, v. 67, p. 134-144.

Braun, C.E., Baker, M.F., Eng, R.L., Gashwiler, J.S., and Schroeder, M.H., 1976, Conservation committee report on effects of alteration of sagebrush communities on the associated avifauna: Wilson Bulletin, v. 88, p. 165-171.

Braun, C.E., Oedekoven, O.O., and Aldridge, C.L., 2002, Oil and gas development in western North America: effects on sagebrush steppe avifauna with particular emphasis on sage grouse: Transactions of the North American Wildlife and Natural Resources Council, v. 67, p. 337-349.

Busby, W.H., and Zimmerman, J.L., 2001, Kansas breeding bird atlas: University Press of Kansas, Lawrence, Kansas.

Castrale, J.J., 1982, Effect of two sagebrush control methods on nongame birds: Journal of Wildlife Management, v. 46, p. 945-952.

Cerovski, A., Gorges, M., Byer, T., Duffy, K., and Felley, D., 2001, Wyoming bird conservation plan, Version 1.0, Wyoming Partners in Flight, Wyoming Game and Fish Department, Lander, Wyoming. Chalfoun, A.D., and Martin, T.E., 2007, Assessments of habitat preferences and quality depend on spatial scale and metrics of fitness: Journal of Applied Ecology, v. 44, p. 983-992.

Croteau, E.K., Lougheed, S.C., Krannitz, P.G., Mahony, N.A., Walker, B.L., and Boag, P.T., 2007, Genetic population structure of the sagebrush Brewer's sparrow, Spizella breweri breweri, in a fragmented landscape at the northern range periphery: Conservation Genetics, v. 8, p. 1453.

Crow, C., and van Riper, C., 2010, Avian community responses to mechanical thinning of a pinyonjuniper woodland: specialist sensitivity to tree reduction: Natural Areas Journal, v. 30, p. 191-201. 
Desmond, M.J., Mendez-Gonzalez, C., and Abbott, L.B., 2008, Winter diets and seed selection of granivorous birds in southwestern New Mexico: Studies in Avian Biology, v. 37, p. 101-112.

Dobkin, D.S., and Sauder, J.D., 2004, Shrubsteppe landscapes in jeopardy: distributions, abundances, and the uncertain future of birds and small mammals in the Intermountain west: High Desert Ecological Research Institute, Bend, Oregon.

Dobler, F.C., Eby, J., Perry, C., Richardson, S., and Vander Haegen, M., 1996, Status of Washington’s shrub-steppe ecosystem: extent, ownership, and wildlife/vegetation relationships: Research Report, Washington Department of Fish and Wildlife, Olympia, Washington.

Doyle, T.J., 1997, The timberline sparrow, Spizella (brewerii) taverneri, in Alaska, with notes on breeding habitat and vocalizations: Western Birds, v. 28, p. 1-12.

Fancy, S.G., and Sauer, J.R., 2000, Recommended methods for inventorying and monitoring landbirds in National Parks, May 5, 2000 Version. Online at http://science.nature.nps.gov/im/monitor/protocols/npsbird.doc. Accessed 1 July 2011.

Fleishman, E., and Dobkin, D.S., 2009, Current and potential future elevational distributions of birds associated with pinyon-juniper woodlands in the central Great Basin, USA: Restoration Ecology, v. 17, p. 731-739.

Gelbard, J.L., and Belnap, J., 2003, Roads as conduits for exotic plant invasions in a semiarid landscape: Conservation Biology, v. 14, p. 420-430.

Greenwood, J.J.D., Baillie, S.R., Crick, H.Q.P., Marchant, J.H., and Peach, W.J., 1993, Integrated population monitoring: detecting the effects of diverse changes: Pp. 267-342 in Furness, R.W., and Greenwood, J.J.D., eds., Birds as monitors of environmental change, Chapman and Hall, London, United Kingdom.

Greiner, E.C., Bennett, G.F., White, E.M., and Coombs, R.F., 1975, Distribution of the avian hematozoa of North America: Canadian Journal of Zoology, v. 53, p. 1762-1787.

Griffin, S.C., Walker, B.L., and Hart, M.M., 2003, Using GIS to guide field surveys for timberline sparrows in northwestern Montana: Northwest Science, v. 77, p. 54-63.

Hansley, P.L., and Beauvais, G.P., 2004, Species assessment for Brewer's sparrow (Spizella breweri) in Wyoming: United States Department of the Interior, Bureau of Land Management, Wyoming State Office, Cheyenne, Wyoming.

Harrison, H., 1979, A field guide to western bird nests: Houghton Mifflin, Boston, Massachusetts.

Harrison, M.L, Green, D.J., and Krannitz, P.G., 2009, Conspecifics influence the settlement decisions of male Brewer's sparrows at the northern edge of their range: Condor, v. 111, p. 722-729.

Herkert, J.R., and Knopf, F.L., 1998, Research needs for grassland bird conservation: Pp. 273-282 in Marzluff, J.M., and Sallabands, R., eds., Avian conservation: research and management, Island Press, Washington, D.C.

Holmes, A.L., 2007, Short-term effects of a prescribed burn on songbirds and vegetation in mountain big sagebrush: Western North American Naturalist, v. 67, p. 292-298.

Holmes, J.A., and Johnson, M.J., 2005, Brewer's sparrow (Spizella breweri): a technical conservation assessment: USDA Forest Service, Rocky Mountain Region, Available online http://www.fs.fed.us/r2/projects/scp/assessment/brewerssparrow.pdf. Accessed 1 July 2011.

Howe, F.P., Knight, R.L., McEwen, L.C., and George, T.L., 1996, Direct and indirect effects of insecticide applications on growth and survival of nestling passerines: Ecological Applications, v. 6, p. 1314-1324.

Hutto, R.L., 1998, Using landbirds as an indicator species group: Pp. 75-92 in Marzluff, J.M., and Sallabands, R., eds., Avian conservation: research and management, Island Press, Washington, D.C. 
Hutto, R.L., and Young, J.S., 1999, Habitat relationships of landbirds in the USFS Northern region: USDA Forest Service General Technical Report RMRS-32.

Ingelfinger, F., 2001, The effects of natural gas development on sagebrush steppe passerines in Sublette County, Wyoming: Unpublished M.S. Thesis, University of Wyoming, Laramie, Wyoming.

Janzen, D.H., 1986, The eternal external threat: Pp. 286-393 in Soule, M.E., ed., Conservation biology: the science of scarcity and diversity, Sinauer Associates, Sunderland, Massachusetts.

Knick, S.T., 1999, Forum: requiem for a sagebrush ecosystem?: Northwest Science, v. 73, p. 47-51.

Knick, S.T., and Rotenberry, J.T., 1995a, Landscape characteristics of fragmented shrubsteppe landscapes and breeding passerine birds: Conservation Biology, v. 9, p. 1059-1071.

Knick, S.T., and Rotenberry, J.T., 1995b, Habitat relationships and breeding passerine birds on the Snake River Birds of Prey Area: Idaho Bureau of Land Management Technical Bulletin No. 95-5, Boise, Idaho.

Knick, S.T., and Rotenberry, J.T., 1997, Landscape characteristics of disturbed shrubsteppe habitats in southwestern Idaho: Landscape Ecology, v. 12, p. 287-297.

Knick, S.T., and Rotenberry, J.T., 1999, Spatial distribution of breeding passerine bird habitats in shrubbsteppe region of southwestern Idaho: Studies in Avian Biology, v. 19, p. 104-111.

Knick, S.T., and Rotenberry, J.T., 2000, Ghosts of habitats past: contribution of landscape change to current habitats used by shrubland birds: Ecology, v. 81, p. 220-227.

Knick, S.T., and Rotenberry, J.T., 2002, Effects of habitat fragmentation on passerine birds breeding in Intermountain shrubsteppe: Studies in Avian Biology, v. 25, p. 131-141.

Knick, S.T., Dobkin, D.S., Rotenberry, J.T., Schroeder, M.a., Vander Haegen, W.M., and van Riper, C., III, 2003, Teetering on the edge or too late? Conservation and research issues for avifauna in sagebrush habitats: Condor, v. 105, p. 611-634.

Knopf, F.L., Sedgwick, J.A., and Inkley, D.B., 1990, Regional correspondence among shrubsteppe bird habitats: Condor, v. 105, p. 611-634.

Krissman, C.M., 2005, Range-wide abundance and fluctuating asymmetry patterns of sagebrushobligate passerine birds: Unpublished M.S. Thesis, Oregon State University, City, Oregon, ?? pp.

Lambeth, R., 1998, Brewer's sparrow, Spizella breweri: Pp. 456-457 in Kingery, H.E., ed., Colorado Breeding Bird Atlas, Colorado Bird Atlas Partnership, Copublished by Colorado Division of Wildlife, Denver, Colorado.

Larson, D.L., and Bock, C.E., 1986, Determining avian habitat preference by bird-centered vegetation sampling: Pp. 37-43 in Verner, J., Morrison, M.L., and Ralph, C.J., eds., Wildlife 2000: modeling habitat relationships of terrestrial vertebrates, University of Wisconsin Press, Madison, Wisconsin.

Ligon, J.S., 1961, New Mexico birds and where to find them: University of New Mexico Press, Albuquerque, New Mexico.

Mahony, N.A., Krannitz, P.G., and Martin, K., 2006, Seasonal fecundity of sagebrush Brewer's sparrow (Spizella breweri breweri) at the northern edge of its breeding range: Auk, v. 123, p. 512-523.

Mahony, N.A., Vander Haegen, W.M., Walker, B.L., and Krannitz, P.G., 2001, Male incubation and multiple brooding in sagebrush Brewer’s sparrows: Wilson Bulletin, v. 113, p. 441-444.

Marzluff, J.M., Boone, R.B., and Cox, G.W., 1994, Historical changes in populations and perceptions of native pest bird species in the West: Studies in Avian Biology, v. 15, p. 202-220.

McIntyre, K.K., 2002, Species composition and beta diversity of avian communities in burned, mixed, and unburned sagebrush steppe habitat at Sheldon National Wildlife Refuge, Nevada: Unpublished M.S. Thesis, Sul Ross University, Alpine, Texas.

Morrison, M.L., 2002, Wildlife restoration: techniques for habitat analysis and animal monitoring: Island Press, Washington, D.C. 
Nordin, K.E., McGillivray, B., and Biermann, G.C., 1988, Courtship feeding in Brewer’s sparrows (Spizella breweri): Journal of Field Ornithology, v. 59, p. 33-36.

Noson, A.C., Schmitz, R.A., and Miller, R.F., 2006, Influence of fire and juniper encroachment on birds in high-elevation sagebrush steppe: Western North American Naturalist, v. 66, p. 343-353.

Oberholser, H.C., 1974, The bird life of Texas, Vol. 2: University of Texas Press, Austin, Texas.

Paige, C., and Ritter, S.A., 1999, Birds in a sagebrush sea: managing sagebrush habitats for bird communities: Partners in Flight Western Working Group, Boise, Idaho.

Paine, R.T., 1968, Brewer's sparrow: Pp. 1208-1217 in Austin, O.L., Jr., ed., Life histories of North American cardinals, grosbeaks, buntings, towhees, finches, sparrows, and allies: United States National Museum Bulletin, v. 237, part 2.

Pavlacky, D.C., and Anderson, S.H., 2001, Habitat preferences of pinyon-juniper specialists near the limit of their geographic range: Condor, v. 103, p. 322-331.

Pavlacky, D.C., and Anderson, S.H., 2004, Comparative habitat use in a juniper woodland bird community: Western North American Naturalist, v. 64, p. 376-384.

Peterjohn, B.G., and Sauer, J.R., 1999, Population status of North American grassland birds from the North American Breeding Bird Survey, 1966-1996: Studies in Avian Biology, v. 19, p. 27-44.

Petersen, K.L., and Best, L.B., 1985, Brewer’s sparrow nest-site characteristics in a sagebrush community: Journal of Field Ornithology, v. 56, p. 23-27.

Petersen, K.L., and Best, L.B., 1986, Diets of nestling sage sparrows and Brewer's sparrow in an Idaho sagebrush community: Journal of Field Ornithology, v. 57, p. 283-294.

Petersen, K.L., and Best, L.B., 1987, Effects of prescribed burning on nongame birds in a sagebrush community: Wildlife Society Bulletin, v. 15, p. 317-329.

Petersen, K.L., and Best, L.B., 1999, Design and duration of perturbation experiments: implications for data interpretation: Studies in Avian Biology, v. 19, p. 230-236.

Petersen, K.L., Best, L.B., and Winter, B.M., 1986, Growth of nestling sage sparrows and Brewer’s sparrows: Wilson Bulletin, v. 98, p. 535-546.

Peterson, R.A., 1995, The South Dakota breeding bird atlas: South Dakota Ornithologists’ Union, Aberdeen, South Dakota.

Pyle, P., and Howell, S.N.G., 1996, Spizella sparrows: intraspecific variation and identification: Birding, v. 28, p. 374-387.

Rappole, J.H., Morton, E.s., Lovejoy, T.E., III, and Ruos, J.L., 1993, Aves migratorias Nearcticas en los Neotropicos: Smithsonian Institution, Washington, D.C.

Reinkensmeyer, D.P., 2000, Habitat associations of bird communities in shrub-steppe and western juniper woodlands: Unpublished M.S. Thesis, Oregon State University, Corvallis, Oregon.

Reinkensmeyer, D.P., Miller, R.F., Anthony, R.G., and Marr, V.E., 2007, Avian community structure along a mountain big sagebrush successional gradient: Journal of Wildlife Management, v. 71, p. 1057-1066.

Reynolds, T.D., 1981, Nesting of sage thrasher, sage sparrow, and brewer's sparrow in southeastern Idaho: Condor, v. 83, p. 61-64.

Rich, T.D., 1978, Cowbird parasitism of sage and Brewer's sparrows: Condor, v. 80, p. 348.

Rich, T.D., 1980, Nest placement in sage thrashers, sage sparrows, and Brewer's sparrows: Wilson Bulletin, v. 92, p. 362-368.

Robinson, S.K., Rothstein, S.E., Brittingham, M.C., Petit, L.J., and Grzybowski, J.A., 1995, Ecology and behavior of cowbirds and their impact on host populations: Pp. 428-460 in Martin, T.E., and Finch, D.M., eds., Ecology and management of neotropical migratory birds, Oxford University press, New York, New York. 
Rotenberry, J.T., 1986, Habitat relationships of shrubsteppe birds: even "good” models cannot predict the future: Pp. 217-221 in Verner, J., Morrison, M.L., and Ralph, C.J., eds., Wildlife 2000: modeling habitat relationships of terrestrial vertebrates, University of Wisconsin Press, Madison, Wisconsin.

Rotenberry, J.T., 1998, Avian conservation research needs in western shrublands: exotic invaders and the alteration of ecosystem processes: Pp. 262-272 in Marzluff, J.M., and Sallabanks, R., eds., Avian conservation: research and management, Island Press, Washington, D.C.

Rotenberry, J.T,. and Wiens, J.A., 1980, Temporal variation in habitat structure and shrubsteppe bird dynamics: Oecologia, v. 47, p. 1-9.

Rotenberry, J.T., and Wiens, J.A., 1989, Reproductive biology of shrubsteppe passerine birds: geographical and temporal variation in clutch size, brood size, and fledgling success: Condor, v. 91, p. $1-14$.

Rotenberry, J.T,. and Wiens, J.A., 1991, Weather and reproductive variation in shrubsteppe sparrows: a hierarchical analysis: Ecology, v. 72, p. 1325-1335.

Rotenberry, J.T., Patten, M.A., and Preston, K.L., 1999, Brewer’s sparrow (Spizella breweri): Poole, A., ed., The Birds of North America Online, Ithaca, Cornell Laboratory of Ornithology, Retrieved from the Birds of North America Online, http://bna.birds.cornell.edu/bna/species/390. Accessed 1 July 2011.

Samson, F.B., and Knopf, F.L., 1994, Prairie conservation in North America: Bioscience, v. 44, p. 418421.

Sauder, J.D., 2002, Factors influencing avian abundance and diversity in sagebrush steppe, juniper woodland, and aspen woodland communities of southeast Idaho: Unpublished M.S. Thesis, Idaho State University, City, Idaho.

Sauer, J.R., Hines, J.E., Gough, G., Thomas, I., and Peterjohn, B.J., 1997, The North American Breeding Bird Survey, Results and Analysis. Version 93.6: U.S. Department of Interior, U.S. Geological Survey, Patuxent Wildlife Research Center, Laurel, Maryland.

Sauer, J.R., Hines, J.E., and Fallon, J., 2004, The North American Breeding Bird Survey, Results and Analysis 1966 - 2002. Version 2003.1. U.S. Department of Interior, U.S. Geological Survey, Patuxent Wildlife Research Center, Laurel, Maryland.

Sauer, J.R., Hines, J.E., Fallon, J.E., Pardieck, K.L., Ziolkowski, D.J., Jr., and Link, W.A., 2011, The North American Breeding Bird Survey, Results and Analysis 1966 - 2009: Version 3.23.2011. Online at http://www.mbr-pwrc.usgs.gov/bbs/bbs.html. Accessed on 12 July 2011.

Schuler, C.A., Rickard, W.H., and Sargeant, G.A., 1993, Conservation of habitats for shrubsteppe birds: Environmental Conservation, v. 20, p. 57-64.

Sedgwick, J.A., 1987, Avian habitat relationships in pinyon-juniper woodland: Wilson Bulletin, v. 99, p. 413-431.

Short, H.L., 1984, Habitat suitability index models: Brewer’s Sparrow: U.S. Fish and Wildlife Service, FWS/OBS-82/10.83.

Stephens, D.A., 1985, Foraging ecology of shrubsteppe birds in central Washington: Unpublished M.S. Thesis, Central Washington University, Ellensburg, Washington.

Swarth, H.S., and Brooks, A., 1925, The timberline sparrow, a new species from northwestern Canada: Condor, v. 27, p. 67-69.

Vallentine, J.F., and Stevens, A.R., 1994, Use of livestock to control cheatgrass-a review: Pp. 202-210 in Monsen, S.B., and Kitchen, S.G., eds., Proceedings: ecology and management of annual rangelands, USDA Forest Service, General Technical Report INT-GTR-313.

Vander Haegen, W.M. and Walker, B, 1999, Parasitism by brown-headed cowbirds in the shrubsteppe of eastern Washington: Studies in Avian Biology, v. 18, p. 34-40. 
Vander Haegen, W.M., Dobler, F.C., and Pierce, D.J., 2000, Shrubsteppe bird response to habitat and landscape variables: Conservation Biology, v. 14, p. 1145-1160.

Vander Haegen, W.M., M.A., Schroeder, and R.M., DeGraaf, 2002, Predation on real and artificial nests in shrubsteppe landscapes fragmented by agriculture: Condor, v. 104, p. 496-506.

Walters, C., 1986, Adaptive management of renewable resources: MacMillen Publishing, New York, New York.

Welch, B.L., 2002, Bird counts in stands of big sagebrush and greasewood: Research Note RMRS-RN16, U.S. Department of Agriculture, Forest Service, Rocky Mountain Research Station, Ogden, Utah.

Whisenant, S.G., 1990, Changing fire frequencies on Idaho’s Snake River plains: ecological and management implications: Pp. 4-10 in McArthur, E.D., Romney, E.M., Smith, S.D., and Tueller, P.T., eds., Proceedings: symposium on cheatgrass invasion, shrub die-off, and other aspects of shrub biology and management, USDA Forest Service General Technical Report, INT-GTR-276.

Wiens, J.A., and Rotenberry, J.T., 1981a, Habitat associations and community structure of birds in shrubsteppe environments: Ecological Monographs, v. 51, p. 21-41.

Wiens, J.A., and Rotenberry, J.T., 1985, Response of breeding passerine birds to rangeland alteration in a North American shrubsteppe locality: Journal of Applied Ecology, v. 22, p. 655-668.

Wiens, J.A., Rotenberry, J.T., and Van Horne, B., 1986, A lesson in the limitation of field experiments: shrubsteppe birds and habitat alteration: Ecology, v. 67, p 365-376.

Wiens, J.A., Rotenberry, J.T., and Van Horne, B., 1987a, Habitat occupancy patterns of shrubsteppe birds: the effects of spatial scale: Oikos, v. 48, p. 132-147.

Wiens, J.A., Van Horne, B., and Rotenberry, J.T., 1990, Comparisons of the behavior of sage and brewer's sparrows in shrubsteppe habitats: Condor, v. 92, p. 264-266.

Williams, M.I., Paige, G.B., Thurow, T.L., Hild, A.L., and Gerow, K.G., 2011, Songbird relationships to shrubb-steppe ecological site characteristics: Rangeland Ecology and Management, v. 64, p. 109118.

Young, J.A., 1994, History and use of semiarid plant communities-changes in vegetation: Pp. 5-8 in Monsen, S.B., and Kitchen, S.G., eds., Proceedings: ecology and management of annual grasslands, USDA Forest Service, General Technical Report INT-GTR-313. 


\section{Savannah Sparrow (Passerculus sandwichensis)}

\section{Introduction}

The savannah sparrow (Passerculus sandwichensis) is widespread and abundant in open habitats throughout North America. Like other grassland birds, it is often overlooked because of its secretive habits. During the breeding season its persistent buzzy song can be heard in agricultural fields, meadows, marshes, coastal grasslands, and tundra. Most populations are migratory, although salt marsh populations in the southwest are mainly resident. Adults tend to reoccupy the same breeding site. Such philopatry

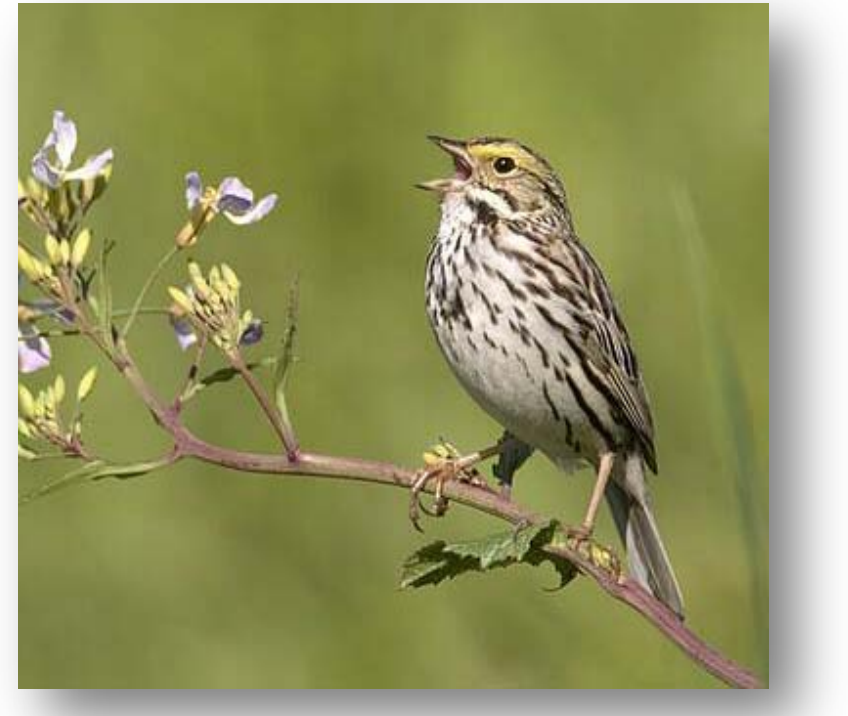

Savannah Sparrow, courtesy of Eleanor Briccetti. has resulted in reproductive isolation and substantial geographic variation; 17 subspecies are currently recognized (Wheelwright and Rising, 2008). The species was named for the town of Savannah, Georgia, where the type specimen was collected. Savannah sparrows have been used as model organisms for the study of avian migratory orientation, with major contributions in the scientific literature by Able and coworkers (Able, 1991; Able and Able, 1990; 1996). Several biological features of this sparrow have made it attractive for studying comparative ecology and evolution, including the species' broad geographic distribution, occurrence in a variety of habitat types, high breeding densities, natal philopatry on islands, and evolutionary divergence of populations.

Savannah sparrows breed across the continent from the Arctic Ocean south to the Great Basin, Rockies, and Appalachians. In Colorado, historical accounts refer to savannah sparrows as common summer residents. Although they breed throughout Colorado, savannah sparrows concentrate in wet streamside meadows and irrigated hayfields in the mountainous regions of the state. North, Middle, and South parks, the upper Yampa Valley, the upper Gunnison Valley, and the San Luis Valley (SLV) contain the bulk of the Colorado's Breeding Bird Atlas confirmations and the largest aggregations of records (Toolen, 1998). Populations increased significantly in western North America from 1969 to 1989 (BBS unpublished data in Wheelwright and Rising, 1993) while declining slightly across the continent from 1966-1996. Forest clearing and more intensive agriculture may explain increases in the West. Irrigated hay meadows are an important component of savannah sparrow habitats in mountain parks and western valleys in Colorado. Prior to settlement these areas were likely already wet grassy meadows, so the loss of irrigated hay meadows to urban and resort development for uses such as golf courses, residences, and ski area base facilities may negatively affect savannah sparrow populations in the future.

A simple Google search on the Internet for "Passerculus sandwichensis" revealed 115,000 results and a Google Scholar search provided 3,680 results (accessed 11 July 2011). "Savannah sparrow” revealed 243,000 results through Google and 4,970 results through Google Scholar (accessed 11 July 2011). 


\section{Natural History}

\section{Morphology \& Systematics}

Savannah sparrows are small and sexually monomorphic in plumage, but these two traits can vary geographically (Wheelwright and Rising, 2008). In basic plumage, the nape, back, and rump are brownish or grayish, and streaked to varying degrees. Throughout much of the species' range, the crown usually has a pale beige median stripe. The eyebrow stripe is yellow, especially anteriorly, and a little yellow is generally concealed in the bend of the wing. The throat, breast, and belly are whitish to pale beige; the breast is generally streaked with brown, often with a small central spot; and the throat and belly can be with or without streaks (Wheelwright and Rising, 2008).

On average, savannah sparrows from eastern North America are darker and larger than those from the Great Plains or West, with many populations blending into each other morphologically, particularly east of the Rocky Mountains (Wheelwright and Rising, 2008). Some 28 different subspecies have been named, but just 17 of these are diagnostically distinct (Wheelwright and Rising, 2008). The subspecies in Colorado is $P$. s. nevadensis (Wheelwright and Rising, 2008). This subspecies breeds from eastern British Columbia east through Manitoba and south to eastern California east across the Great Basin and northern Great Plains.

Migration

All populations of this species migrate except for those resident along the coast of California, and those that breed in Mexico (Wheelwright and Rising, 2008). There is little direct information on migration for savannah sparrows; however, birds that breed on the Mexican Plateau, Arizona, and New Mexico probably move south or to lower elevations in winter. Before 1987, only four migratory individuals banded on breeding grounds had been recovered in winter, and only one banded in winter had been recovered on the breeding grounds (Bird Banding Lab; Wheelwright and Rising, 2008).

In spring, savannah sparrows arrive by late February in Kentucky (Mengel, 1965), early March in Missouri (Robbins and Easterla, 1992), early April in South Dakota (South Dakota Ornithologists' Union, 1991), late March in southern Ontario, early May in northern Ontario (Speirs, 1985), mid-April in Nova Scotia (Tufts, 1986), late March in Oregon (Gabrielson and Jewett, 1940), and early May in Alaska (Gabrielson and Lincoln, 1959). In fall, savannah sparrows depart Alaska in mid- to late September (Gabrielson and Lincoln, 1959), South Dakota by early November, northern Ontario by midOctober (Speirs, 1985), New Brunswick by mid-September, and Nova Scotia by late October (Stobo and McLaren, 1975). Migrants appear in Kentucky from early September through mid-November (Mengel, 1965), in Georgia by early September (Georgia Ornithological Society, 1986), in Florida by late September (Kale and Maehr, 1990), in Missouri from mid-September through November (Robbins and Eastera, 1992), in Arkansas by mid-September (James and Neal, 1986), in Oregon from late September through early November (Gabrielson and Jewett, 1940), and in southern California by late August (Unitt, 1984).

Habitat

Breeding range habitat for savannah sparrows is open country, including grassy meadows, cultivated fields (especially alfalfa), lightly grazed pastures, roadsides, coastal grasslands, sedge bogs, edge of salt marshes, and tundra (Wheelwright and Rising, 2008). Savannah sparrows avoid areas with extensive tree cover, and generally occupy fields with some herbaceous plants or weeds. In arid parts of their range, they are generally restricted to irrigated areas or to the grassy margins of ponds. Savannah 
sparrows prefer dense ground vegetation, especially grasses, and moist microhabitats are favored (Wiens, 1969). In Colorado, moist, grassy, mountain meadows are favored breeding habitats, but irrigated hay meadows and alfalfa are also important breeding areas throughout Colorado (Toolen, 1998). Colorado’s Breeding Bird Atlas data confirmed these habitat preferences for Colorado, with croplands, montane grassland, and emergent marshes accounting for 58 percent of habitats reported. Salt meadows, mountain sagebrush, montane carr, and willow carr made up another 22 percent of sightings. Winter habitats for savannah sparrows are cultivated fields, pastures, golf courses, roadsides, dumps, dune grass, and salt marshes (Wheelwright and Rising, 2008).

A 4-year study in tallgrass prairie in Minnesota and North Dakota found it difficult to define "optimal" habitat for savannah sparrows. Breeding density varied among regions and years and was influenced by landscape effects independent of the size of the grassland patches; the influence of patch size and landscape composition on nesting success was unclear (Winter and others, 2006). In North Dakota mixed-grass prairie habitats of various successional stages, savannah sparrows are ubiquitous and generalized in habitat preferences (Madden and others, 2000). In Saskatchewan, the presence or absence of breeding savannah sparrows in different-sized tallgrass pastures varied among years, suggesting the species was relatively area-insensitive (Davis, 2004). Field size also proved to be a poor predictor of breeding density in several north-central states in the United States (Johnson and Igl, 2001; Ribic and Sample, 2001). In contrast, area-incidence functions indicated that savannah sparrows require open areas of 10-15 ha in grasslands and blueberry barrens (O’Leary and Nyberg, 2000) and in South Dakota, savannah sparrows were found to be area-sensitive and used only large grassland patches (Bakker and others, 2002).

\section{Foraging Habits}

During the breeding season, savannah sparrows forage primarily on adult and larval insects, spiders, seeds and fruits (Wheelwright and Rising, 2008). Occasionally, they will eat insect eggs, millipedes, isopods, amphipods, decapods, mites, and small mollusks (Baird, 1968; Maher, 1979; Meunier and Bedard, 1984). Savannah sparrows forage on the ground in short vegetation in pastures, sedge bogs, tundra, beach wrack, mud flats (near cover), and dunegrass (Wheelwright and Rising, 2008). In winter, savannah sparrows feed primarily on small seeds of grasses and other herbs, smallseeded fruits, insects, and spiders (Desmond and others, 2008). They forage on the ground in grasslands, cultivated fields, roadsides, dunegrass, and salt marshes (Ginter and Desmond, 2005).

\section{Breeding}

Although territories that the males defend had very small dimensions ( $0.11 \mathrm{ha}$ ) in Michigan, the defended area often had unoccupied space around it (Ryser, 1985). Males spend only about 66 percent of their time on the territory and feed in nonterritorial common areas. In contrast, females feed mostly within their mates' territories. Pairs whose members survive typically breed together in subsequent years (Wheelwright and Rising, 1993). The female alone builds the nest and it is usually well hidden on the ground. Nests are concealed under grass clumps with a canopy of dead grasses and herbs. Some populations have second broods, but this depends on climate and whether the male assumes postfledging care of the first brood. Clutch size ranges from two to six eggs across their range, but with a latitudinal gradient from north to south of larger clutches in the northern parts of the range (Wheelwright and Rising, 2008). Only the female incubates the eggs (Potter, 1974; Stobo and McLaren, 1975; Baird, 1968; Bedard and Meunier, 1983).

Brown-headed cowbirds may lay eggs in savannah sparrow nests where the two species co-occur (Freidmann and others, 1977). However, recorded frequency of brood parasitism is low (Wheelwright 
and Rising, 2008). Four records of brown-headed cowbird nest parasitism exist for Colorado, including two records from Colorado’s Breeding Bird Atlas (Toolen, 1998).

\section{Demography \& Populations}

Age at first breeding is one year for both males and females (Wheelwright and Rising, 2008). Overall reproductive success is apparently higher on islands because of an absence of mammalian predators (Stobo and McLaren, 1975), and reproductive output is low during years of inclement weather.

Annual survivorship of breeding adults in Nova Scotia averaged 35 percent (28-42 percent; Stobo and McLaren, 1975); Quebec, 31-45 percent (Bedard and LaPointe, 1984a; 1984b); Kent Island, New Brunswick, 45-50 percent (Dixon, 1972); and, Michigan, 68-70 percent (Potter, 1974). About 40 percent of adults are estimated to return to the same wintering area in successive years (Odum and Hight, 1957). Adult survival not only varies geographically, but varies widely among years (37-73 percent; Wheelright and others, 1992).

Densities of savannah sparrows are greatest on islands, possibly because of extreme philopatry, fewer competing species, and less predation because of fewer mammalian predators (Wheelwright and Rising, 2008). On Kent Island, New Brunswick, as many as 20 females breed per hectare in some habitats, although more typical densities are 4-5 pairs/ha. Density of savannah sparrows declines with plant succession as shrubs invade open areas (Potter, 1974; Weatherhead, 1979a). Winter densities in habitat such as agricultural fields was reported to be 4.0 birds/ha, but as high as 30 birds/ha where food and cover were plentiful (Norris, 1960). In addition to islands, greatest densities of savannah sparrows are found along the St. Lawrence River, around the Great Lakes, in northern Minnesota, Saskatchewan and Manitoba, and in the Pacific Northwest (Wheelwright and Rising, 2008).

Populations of savannah sparrows increased significantly in western North America from 1969 to 1989 (BBS unpublished data in Wheelwright and Rising, 1993) while declining slightly across the continent from 1966-1996. However, when BBS results were combined from 1966 to 2005, savannah sparrows showed significant population declines in the United States and in Canada. In the Eastern and Western BBS survey regions, populations also declined, but populations increased significantly in the Central region (Wheelwright and Rising, 2008). Populations declined notably around the Great Lakes and Illinois east to western Pennsylvania (Sauer and others, 2011). As with many other grassland birds, more intensive agriculture, the shift to cash crops (corn, wheat, soybean), and declines in dairy farming have resulted in decreasing population sizes, based on BBS data (Jobin and others, 1996).

The Breeding Bird Survey (BBS) regional trend analysis for savannah sparrows along 71 Colorado routes from 1966 to 1999 showed a slight positive trend estimate of 0.2 (-1.2, 1.8; 95 percent CI) (Sauer and others, 2011). From 1999 to 2009, the trend was also positive and estimated to be 1.9 (0.8, 4.9; 95 percent CI). The regional credibility measure for this species was the category "blue.” A blue category reflects data with at least 14 samples in the long term, of moderate precision, and of moderate abundance on routes.

\section{Threats}

\section{Sources of Mortality}

In 3-4 percent of broods of savannah sparrows in eastern Quebec, nestlings were infested subcutaneously with larval blow flies (Calliphoridae), which retarded feather growth and, in one case, caused the loss of an eye (Bedard and McNeil, 1979). Ectoparasites are uncommon on adult birds (Wheelwright and Rising, 2008). Avian louse flies (Hippoboscidae; Baird, 1968) were found on 10 
percent of recently independent juveniles; were less commonly found on adults. Fewer than 1 percent of adults carry ticks and when found, they are usually around the face. There are various blood protozoans known to infect savannah sparrows (Baird, 1968).

Nest predation is the primary source of nest failure for grassland passerines, including savannah sparrows (Koford, 1999; Jones and Dieni, 2007). Small mammals, considered the primary threat to ground nests in the northern Great Plains (Pietz and Granfors, 2000; Davis, 2003), opportunistically find grassland bird nests while foraging for invertebrates. Data from Kent Island, New Brunswick, indicated the daily mortality rate of eggs and nestlings was 11.9 percent and 2.1 percent, respectively, and the author determined that predation was the major factor affecting reproductive success (Dixon, 1978). In this location, the main nest predators were common crows and herring gulls.

\section{Effects of Human Activity}

Across their range, savannah sparrows have generally benefitted from human activity, at least until the past few decades (Wheelwright and Rising, 2008). Twentieth century savannah sparrow densities are probably greater than at any time in the past because of this species' dependence on open habitats (fields, blueberry barrens, hay fields, cropland) for breeding and over-wintering. Post-war urbanization in the eastern United States and reversion of marginal farms to forest may partly explain population declines in the Northeast and around the Great Lakes. Landscape changes caused by the shift in agricultural practices from dairy-farming to cash crops (for example, corn, wheat, soybean) have been associated with declines in savannah sparrow densities in Quebec (Jobin and others, 1996). Forestclearing and more intensive agriculture in the west may explain population increases there until recently.

Breeding savannah sparrows are relatively tolerant of human disturbance at the nest (Baird, 1968; Welsh, 1975). Pairs nest readily in human-made grasslands such as reclaimed surface mines, but reproductive success in such habitats may be so low that they effectively serve as population "sinks" (Wray and others, 1982). Pesticide use in agricultural fields probably has negative effects on savannah sparrows, but so far such effects have been documented only in the case of dimethoate, an organophosphate which reduced mean daily activity levels of the birds, which then had a recovery time from intoxication of 11.5 days (Brunet and Cyr, 1992). Savannah sparrows appear more likely than other birds to ingest pesticide granules applied to cornfields (Wheelwright and Rising, 2008).

\section{Management}

\section{Mowing/Haying}

According to Wheelwright and Rising (2008), grassland management, particularly mowing regimes, is critical for maintaining mainland populations of savannah sparrows. Mowing of grassland fields has at least four effects on grassland birds: (1) it alters the vegetative characteristics of the field, changing its suitability for individual grassland species (Owens and Myres, 1973; Dale and others, 1997); (2) it displaces individuals from a field, causing an egress of birds to nearby fields (Bryan and Best, 1991; Igl, 1991); (3) mowing in the breeding season destroys or causes abandonment of a large proportion of the nests that were active just prior to mowing (Bollinger and others, 1990; Frawley and Best, 1991; Kershner and Bollinger, 1996; Dale and others, 1997) and repeated mowing may not allow birds to complete their nesting cycles (Bollinger and others, 1990; Herkert and others, 1960; Koford and Best, 1996); and, (4) fields mowed during the breeding season may have lower breeding densities the following year due to greater nest failure experienced previously and reduced site fidelity (Bollinger, 1995; Dale and others, 1997). Rodenhouse and others (1995) synthesized the effects of mowing on 
grassland birds and suggested that mowed grassland fields would be less suitable for some species (for example, bobolinks) than idled fields, whereas mowed fields would be more suitable for other species (for example, savannah sparrows).

Earlier and more frequent harvests in agricultural grasslands in recent decades have been implicated as major cause of population declines in savannah sparrows and other grassland songbirds (Kirsch and others, 1978; Wheelwright and Rising, 2008). Hayfields are unique breeding habitats in that dramatic structural changes occur due to harvesting during the breeding season (Zalik, 2007). These harvesting processes, along with the subsequent predation of exposed nests, can cause nearly 100 percent failure of all active nests (Perlut and others, 2006). In Saskatchewan, breeding densities were greater in idle hayfields than in annually mowed fields; mowing resulted in an 80 percent decline in productivity (Dale and others, 1997). However, in North Dakota on Conservation Reserve Program lands, savannah sparrows were more abundant in portions of fields that were mowed the previous year (Horn and Koford, 2000). Haying before June 11 caused 99 percent nest failure in Vermont; delaying haying until at least June 21 results in 2.7-fold increase in the number of fledglings per female per year (Perlut and others, 2006). In Nova Scotia, a one-week delay in hay-cutting increased fledging success from 0 to 56 percent, with minimal loss of hay nutritional value (Nocera and others, 2005).

Zalik (2007) studied savannah sparrows in both harvested and unharvested hayfields in the Champlain Valley of Vermont. The removal of vegetation through haying likely influences the invertebrate community, which is a primary diet item for both adults and young (Vickery and others, 2001; Schmidt and others, 2005; Britschgi and others, 2006). Any effects on these food sources may influence the fitness of young and adult savannah sparrows. Zalik (2007) studied food habits of breeding savannah sparrows and found that caterpillars and sawfly larvae were consistently used more than expected based upon their availability. This was true, even later in the season, particularly on cut fields, when larvae constituted only a small proportion of available prey, which lead to the conclusion that adults may have been able to provide their nestlings with relatively more larvae on cut fields.

Perlut (Perlut, 2007; Perlut and others, 2008) studied the effects of hayfield management on grassland songbirds in the same area as Zalik (2007). The ecology of savannah sparrows was studied in four grassland management types: (1) early-hayed fields harvested in late-May or early-June and again in mid-July; (2) middle-hayed fields harvested in late-June or early-July; (3) late-hayed fields harvested after 1 August; and, (4) rotationally-grazed pastures, a matrix of small paddocks where cows were moved after the grass in a paddock was eaten to a low point. This study found that early-hayed fields were low-quality habitats for reproduction. Female savannah sparrows on middle- and late-hayed fields fledged 2.6 - 2.7 times more young each year than females on early-hayed fields, even though females on early-hayed fields built more nests and laid more eggs. Predation rates between the first and second haying were highly variable. In extreme years, predation caused 59-69 percent of the failures on earlyhayed fields, while in other years only 9-18 percent of failed nests were depredated. High predation resulted in asynchronous nesting, which again caused more nests to be vulnerable to a second mid-July haying. Perlut (2007; Perlut and others, 2008) also found that savannah sparrows breeding in lessintensively managed grasslands (late-haying) incurred higher apparent survival than those breeding in intensively managed grasslands (early-haying, middle-haying, and grazing). Birds using late-hayed fields had $>25$ percent higher survival than those on more intensively managed early-hayed, middlehayed, and grazed fields. Recruitment was highest on both intensively and moderately managed fields, perhaps as result of the lower apparent survival on these fields. For the Champlain Valley area of Vermont, Perlut and others (2008) recommended that advancing the initial harvest of hayfields in lateMay and delaying the second harvest for 65 days would benefit reproduction, recruitment, and survival 
for savannah sparrows. They also suggested increasing the preference for late-hayed fields by removing grass at the end of each season.

Dieni (2009) examined the effects of haying on breeding bird community and habitat structure at the Baca NWR in 2009. Idle units were rested during 2008, while treated units were hayed during August and September of 2008. He found that the species composition of breeding birds and relative abundance of the most dominant species was structurally similar between haying and idle treatments. However, savannah sparrows were on average 20 percent more abundant on the idle units, although the effect varied with visit (Dieni, 2009). Little difference was observed during the late June visits; conversely, savannah sparrows were over 43 percent more abundant on the idle units during late July. Possible explanations for the increased abundance on idle units included (1) idle treatments were more productive, (2) increased fledgling activity, and (3) idle units tended to have a greater percentage of area that lacked standing water, thus more potential nest sites, since savannah sparrows place nests directly on the ground (Wheelwright and Rising, 1993). Dieni (2009) suggested that a long-term monitoring study would be instructive where one or more units are left idle indefinitely, with hayed controls for comparison. Such a monitoring study would require a well-conceived monitoring plan, and a commitment to measure both avian and vegetative parameters at regular intervals. This would not necessarily have to happen annually.

Blank and others (2011) examined the effects of fall mowing of herbaceous buffers on wintering savannah sparrows on the eastern shore of Maryland. Mowing in this area is a common maintenance practice to control woody plants and noxious weeds in herbaceous buffers. Buffers cannot be mowed during the primary bird nesting season between 15 April and 15 August. Therefore, most mowing occurs in the late summer and early fall. Savannah sparrows were significantly more abundant in unmowed buffers, suggesting that unmowed buffers provide better habitat for wintering savannah sparrows.

Warren and Anderson (2005) studied the effects of mowing on savannah sparrows at the Canaan Valley National Wildlife Refuge, West Virginia. Mowing took place after the breeding season in late August. They found that nest success rates were similar between mowed and unmowed treatments, indicating that although vegetative structure was altered, mowing did not influence overall nest-failure rates.

\section{Grazing}

Owens and Myres (1973), in a southern Alberta study, found that disturbance of a native fescue (Festuca scabrella) grassland by mowing or cattle grazing did not affect savannah sparrow populations. In Saskatchewan, however, Maher (1973) found that four of seven species that regularly breed in grasslands prefer ungrazed prairie, including the savannah sparrow.

Kwasny (2000) examined the effects of cattle grazing on savannah sparrows in northcoastal California at the Humboldt Bay National Wildlife Refuge. Cattle grazing is used to create short-grass habitat for wintering and migrating shorebirds and waterfowl. Kwasny looked at territory size, density, and reproductive success of savannah sparrows in relation to vegetation cover and structure in yearround grazed, seasonally grazed, and ungrazed pastures during 1995 and 1996. He found that territory size did not differ among grazing regimes, but territory density and reproductive success were both higher in the ungrazed treatments compared to the grazed treatments. Vegetation structure was taller and more homogeneous in the ungrazed treatments, and savannah sparrow territory density and reproductive success were positively correlated with the average height of vegetation. He suggested delaying grazing until after 1 June or later would greatly increase the density and nesting success of savannah sparrows 
on the pastures. A delay in grazing would also allow young birds to become mobile and avoid being trampled by cattle.

Rotationally and continuously grazed pastures in riparian areas in Wisconsin held equal numbers of savannah sparrows, although birds avoided buffer strips; higher densities occurred on sites with deeper litter (Renfrew and Ribic, 2001; 2002). However, intensive grazing substantially reduced savannah sparrow densities on islands in the St. Lawrence River, Quebec (Blank, 1999).

On northern mixed-grass prairies protected for conservation, active management such as grazing and burning is considered necessary to restore and maintain ecological integrity (Kerns and others, 2010). At Lostwood National Wildlife Refuge in northwestern North Dakota, a prescribed burn program was implemented in the late 1970s to reduce exotic and woody vegetation. Because fire was not adequately promoting native grasses or reducing exotic smooth brome (Bromus inermis), rotational grazing was added in the 1990s. Kerns and others (2010) investigated the influence of rotational grazing on nest survival of 3 passerine species, including the savannah sparrow. Nest survival of savannah sparrows was found to be lower when cattle were present than when cattle were absent, and the authors suggested that limiting the area actively grazed during the breeding season could reduce nest mortality of passerines.

Cattle may actively predate savannah sparrow nests. In Wisconsin in 2000-2001, Nack and Ribic (2005) used video cameras to document cows removing three of four savannah sparrow eggs from one nest and all three nestlings from a second nest. Seven of 14 (50 percent) cattle-caused nest failures were inadvertent disturbances; a cow laid on one nest, one was abandoned, two were trampled, and the camera was knocked down at three nests, crushing the eggs. They postulated that cows may have eaten the egg and nestlings, or alternatively, the egg and nestlings may have been scavenged by predators or removed from the area by adult birds.

\section{Burning}

In southeastern Arizona, Gordon (2000) studied the effects of spring/summer burning and cattle grazing on wintering sparrows. The effects of fire were studied with 1 year of pre-burn data and 1 year of post-burn data from one fire, plus limited sampling from a second fire. The effects of grazing were studied by comparing study plots at a site that had not been grazed by cattle since 1968 with a nearby grazed pasture. Savannah sparrows were more abundant on burned plots before the fire. In the winter subsequent to the fire, no difference was detected, suggesting that the savannah sparrows responded positively to the burn. The effects of cattle grazing on wintering savannah sparrows were less clear; limited data suggested that severe grazing negatively effects the abundance of sparrows.

In another study in southeastern Arizona, Bock and Bock (1992) studied the response of birds to wildfire in native versus exotic grasslands. A wildfire in 1987 completely burned 11 native and 11 exotic grassland plots. The fire reduced grass and shrub cover, and increased herb cover, for 2 post-fire years in both grassland types. Numbers of fall birds, including savannah sparrows, increased dramatically on burned plots in both native and exotic plots for 2 years, probably in response to increased seed production and availability.

In a study of the effects of fire on prairie grassland birds at the Texas Mid-coast National Wildlife Refuge Complex, savannah sparrows were most highly associated (almost exclusively) with 1year-since-burn conditions and where vegetation was sparse (Grace and others, 2005). Conversely, in north-central North Dakota, the number of savannah sparrow pairs were lowest during the first postfire growing season but generally increased and stabilized within 2-3 years postfire (Grant and others, 2010). At another site on the Texas gulf coast in tallgrass prairie, wintering savannah sparrows were also found to prefer recently burned patches (Marx and others, 2008). Baldwin and others (2007) also 
found savannah sparrows associated with areas burned within one year, with sparse herbaceous vegetation, and with sparse shrub densities (Baldwin and others, 2007).

Conversely, in Saskatchewan, savannah sparrows were adversely affected by a prescribed burn in a fescue grassland (Pylypec, 1991). By the third post-burn year, the density of savannah sparrows was 68 percent of the value observed in the unburned area. In this particular location, only vesper sparrows showed a preference for the burned area in the first year after the burn.

\section{Other Management}

Below is a selection of studies found in the literature that examined the effects of different management schemes on savannah sparrows:

- Thompson and others (2009) examined the relative abundance of grassland birds, including savannah sparrows, among Conservation Reserve Program (CRP) fields seeded with 2 monocultures of introduced grass species and 2 mixes of native grasses in the southern High Plains of Texas. The introduced fields were monocultures of weeping lovegrass (Eragrostis curvula) and Old World bluestem (Bothriochloa ischaemum). The native fields were mixes of principally sideoats gramma (Bouteloua curtipendula), blue gramma (Bouteloua gracilis), green sprangletop (Leptochloa dubia), switchgrass (Panicum virgatum), and buffalograss (Buchloe dactyloides). No breeding season differences among cover types in total avian abundance or species richness were observed. In contrast, during the winter season more species and a greater abundance of grassland birds were detected among fields with native seeding than with introduced seeding. Savannah sparrows were 96 percent more abundant among native CRP than introduced CRP fields.

- Martin and Forsyth (2003) studied the occurrence and productivity of savannah sparrows in prairie farmland under conventional and minimal tillage regimes in Alberta. In conventional tillage, crops were frequently plowed, disced and cultivated after harvest in the fall. Fields then received 2-5 passes with a cultivator or disc, and were harrowed prior to planting, reducing surface crop residue to less than 30 percent of the soil surface. In minimum tillage, crops were seeded directly into standing stubble of the previous crop. They found that savannah sparrows preferred areas of minimum tillage and had the highest productivity in spring cereal and winter wheat.

- Bock and others (1999) examined grassland bird abundance at a suburban interface in Boulder, Colorado. They counted nesting songbirds for three summers on sixty-two 200-meter-diameter plots and found that savannah sparrows were significantly more abundant on interior plots, independent of habitat type. Most of the grassland birds in their study avoided suburban edges. Bock and others (1999) suggested that if the management goal is to conserve native grassland birds on the western Great Plains, grassland open-space systems in the region should be designed to reduce edges with suburban development.

- Graves and others (2010) studied the influence of woody vegetation on grassland birds within reclaimed surface mines and found that savannah sparrows were negatively associated with percent cover of woody vegetation within $100 \mathrm{~m}$ of survey locations. They suggested that management efforts that remove woody vegetation would enhance the value of reclaimed surface mines for grassland birds. Removal of encroaching woody plants would increase the grassland area and reduce edges and fragmentation. This practice may also decrease numbers of woodland predators by eliminating cover or perches and reducing movement corridors.

- Savannah sparrows declined significantly in response to an impoundment and subsequent increase in water level on the shores of Lake Sainte-Anne, Quebec (Lariviere and Lepage, 2000). 
Although rising water levels benefited certain avian species such as waterbirds, low-nesting species were negatively affected.

- Daily nest survival probabilities for savannah sparrows were found to be higher in pastures/hayfields than in fallow fields in western New York (Norment and others, 2010).

- The effects of an invasive plant, leafy spurge (Euphorbia esula), infestation on grassland birds was examined in North Dakota on the Sheyenne National Grassland (Scheiman and others, 2003). Savannah sparrow density was lower on high-spurge points than on low and mediumspurge points. However, spurge cover did not appear to be an important factor in nest-site selection.

- Both mowing and burning were used to restrict shrubland encroachment and maintain grassland habitat on Nantucket Island, Massachusetts (Zuckerberg and Vickery, 2006). Management included prescribed burning on 142 ha of scrub oak shrubland and $>26$ ha of grassland/heathland, and repeated mowing and brush cutting on 205 ha of shrubland. The frequency of the management activities differed among study sites: shrubland areas were burned no more than once, and mowing frequently ranged from 0 (control areas) to 1-3 cuts annually. Bird surveys were conducted during the breeding season. Savannah sparrow abundance did not differ among grasslands that had been burned, mowed, or left unmanaged.

\section{Research Priorities}

Dieni (2009) suggested that a long-term monitoring study of savannah sparrows would be instructive in which one or more units are left idle indefinitely, with hayed controls for comparison. Such a monitoring study would require a well-conceived monitoring plan, and a commitment to measure both avian and vegetative parameters at regular intervals. This would not necessarily have to happen annually.

Vickery and Herkert (2001) suggested that research directed at determining the causes of grassland-bird population declines needs to consider the possibility that population problems may be occurring on winter grounds. The wintering ecology of many grassland species is poorly known.

\section{Bibliography}

Able, K.P., 1991, Common themes and variations in animal orientation systems: American Zoologist, v. 31, p. 157-167.

Able, K.P., and Able, M.A., 1990, Ontogeny of migratory orientation in the savannah sparrow, Passerculus sandwichensis: calibration of the magnetic compass: Animal Behaviour, v. 39, p. 905913.

Able, K.P., and Able, M.A., 1996, The flexible migratory orientation system of the savannah sparrow (Passerculus sandwichensis): Journal of Experimental Biology, v. 199, p. 3-8.

Ashenhurst, A.R., and Hannon, S.J., 2008, Effects of seismic lines on the abundance of breeding birds in the Kendall Island Bird Sanctuary, Northwest Territories, Canada: Arctic, v. 61, p. 190-198.

Baird, J., 1968, Passerculus sandwhichensis savannah, Eastern savannah sparrow: Pp. 678-698 in

Austin, O.L., Jr., ed., Life histories of North American cardinals, grosbeaks, buntings, towhees, finches, sparrows, and allies: Bulletin of the U.S. National Museum.

Bakker, K.K., Naugle, D.E., and Higgins, K.F., 2002, Incorporating landscape attributes into models for migratory grassland bird conservation: Conservation Biology, v. 16, p. 1638-1646.

Baldwin, H.Q., Grace, J.B., Barrow, W.C., and Rohwer, F.C., 2007, Habitat relationships of birds overwintering in a managed coastal prairie: Wilson Journal of Ornithology, v. 119, p. 189-197. 
Bedard, J., and LaPointe, G., 1984a, Banding returns, arrival times, and site fidelity in the savannah sparrow: Wilson Bulletin, v. 96, p. 196-205.

Bedard, J., and LaPointe, G., 1984b, The savannah sparrow territorial system: can habitat features be related to breeding success?: Canadian Journal of Zoology, v. 62, p. 1819-1828.

Bedard, J., and Meunier, M., 1983, Parental care in the savannah sparrow: Canadian Journal of Zoology, v. 61, p. 2836-2843.

Belanger, L., and Picard, M., 1999, Cattle grazing and avian communities of the St. Lawrence River Islands: Journal of Range Management, v. 52, p. 332-338.

Blank, P.J., Parks, J.R., and Dively, G.P., 2011, Wintering bird response to fall mowing of herbaceous buffers: Wilson Journal of Ornithology, v. 123, p. 59-64.

Bock, C.E., and Bock, J.H., 1992, Response of birds to wildfire in native versus exotic Arizona grassland: Southwestern Naturalist, v. 37, p. 73-81.

Bock, C.E., Bock, J.H., and Bennett, B.C., 1999, Songbird abundance in grasslands at a suburban interface on the Colorado high plains: Studies in Avian Biology, v. 18, p. 131-136.

Bollinger, E.K., 1995, Successional changes and habitat selection in hayfield bird communities: Auk, v. 112, p. 720-730.

Bollinger, E.K., Bollinger, P.B., and Gavin, T.A., 1990, Effects of hay-cropping on eastern populations of the bobolink: Wildlife Society Bulletin, v. 18, p. 142-150.

Britschgi, A., Spaar, R., and Arlettaz, R., 2006, Impact of grassland farming intensification on the breeding ecology of an indicator insectivorous passerine, the Winchat Saxicola rubetra: lessons for overall alpine meadow management: Biological Conservation, v. 130, p. 193-205.

Brunet, R., and Cyr, A., 1992, The impact of dimethoate on rhythms of 3 granivorous bird species: Agricultural Ecosystems and Environment, v. 41, p. 327-336.

Bryan, G.G., and Best, L.B., 1991, Bird abundance and species richness in grassed waterways in Iowa rowcrp fields: American Midland Naturalist, v. 126, p. 90-102.

Dale, B.C., Martin, P.A., and Taylor, P.S., 1997, Effects of hay management on grassland songbirds in Saskatchewan: Wildlife Society Bulletin, v. 25, p. 161-626.

Davis, S.K., 2003, Nesting ecology of mixed-grass prairie songbirds in southern Saskatchewan: Wilson Bulletin, v. 115, p. 119-130.

Davis, S.K., 2004, Area sensitivity in grassland passerines: effects of patch size, patch shape, and vegetation structure on bird abundance and occurrence in southern Saskatchewan: Auk, v. 121, p. 1130-1145.

Davis, S.K., 2005, Nest-site selection patterns and the influence of vegetation on nest survival of mixedgrass prairie passerines: Condor, v. 107, p. 605-616.

Desmond, M.J., Mendez-Gonzalez, C., and Abbott, L.B., 2008, Winter diets and seed selection of granivorous birds in southwestern New Mexico: Studies in Avian Biology, v. 37, p. 101-112.

Dieni, J.S., 2009, The effects of haying on wet-meadow birds and habitat at Baca National Wildlife Refuge, Colorado: Unpublished Draft Report to the U.S. Fish and Wildlife Service, Redstart Consulting, Evergreen, Colorado.

Dixon, C.L., 1972, A population study of savannah sparrows on Kent Island in the Bay of Fundy: Unpublished PhD Dissertation, University of Michigan, Ann Arbor, Michigan.

Dixon, C.L., 1978, Breeding biology of the savannah sparrow on Kent Island: Auk, v. 95, p. 235-346.

Dornak, L.L., 2010, Breeding patterns of Henslow's sparrow and sympatric grassland sparrow species: Wilson Journal of Ornithology, v. 122, p. 635-645. 
Environment Canada, 2006, Management plan for the savannah sparrow, princeps subspecies (Passerculus sandwichensis princeps), in Canada: Species of Risk Act Management Plan Series, Environment Canada, Ottawa.

Fajardo, N., Strong, A.M., Perlut, N.G., and Buckley, N.J., 2009, Natal and breeding dispersal of bobolinks (Dolichonyx oryzivorus) and savannah sparrows (Passerculus sandwichensis) in an agricultural landscape: Auk, v. 126, p. 310-318.

Fernandez-Juricic, E., Zahn, E.F., Parker, T., and Stankowich, T., 2009, California's endangered belding's savannah sparrow (Passerculus sandwichensis beldingi): tolerance of pedestrian disturbance: Avian Conservation and Ecology, v. 4, p. 1-15.

Frawley, B.J., and Best, L.B., 1991, Effects of mowing on breeding bird abundance and species composition in alfalfa fields: Wildlife Society Bulletin, v. 19, p. 135-142.

Freeman-Gallant, C.R., 1997, Extra-pair paternity in monogamous and polygynous savannah sparrows, Passerculus sandwichensis: Animal Behaviour, v. 53, p. 397-404.

Friedmann, H., Kiff, L.F., and Rothstein, S.I., 1977, A further contribution to knowledge of the host relations of parasitic cowbirds: Smithsonian Contributions to Zoology, v. 235, p. 1-75.

Gabrielson, I.N., and Jewett, S.G., 1940, Birds of Oregon: Oregon State College, Corvallis, Oregon.

Gabrielson, I.N., and Lincoln, F.C., 1959, Birds of Alaska: Stackpole Company, Harrisburg, Pennsylvania.

Georgia Ornithological Society, 1986, Annotated checklist of Georgia birds: Occasional Publication No. 10.

Ginter, D.L., and Desmond, M.J., 2005, Influence of foraging and roosting behavior on home-range size and movement patters of savannah sparrows wintering in south Texas: Wilson Bulletin, v. 117, p. 6371.

Gordon, C.E., 2000, Fire and cattle grazing on wintering sparrows in Arizona grasslands: Journal of Range Management, v. 53, p. 384-389.

Grace, J.B., Allain, L.K., Baldwin, H.Q., Billock, A.G., Eddleman, W.R., Given, A.M., Jeske, C.W., and Moss, R., 2005, Effects of prescribed fire in the coastal prairies of Texas: U.S. Geological Survey Open-File Report, 2005-1287.

Grant, T.A., Madden, E.M., Shaffer, T.L., and Dockens, J.S., 2010, Effects of prescribed fire on vegetation and passerine birds in northern mixed-grass prairie: Journal of Wildlife Management, $\mathrm{v}$. 74, p. 1841-1851.

Graves, B.M., Rodewald, A.D., and Hull, S.D., 2010, Influence of woody vegetation on grassland birds within reclaimed surface mines: Wilson Journal of Ornithology, v. 122, p. 646-654.

Grzybowski, J.A., 1982, Population structure in grassland bird communities during winter: Condor, v. 84, p. 137-152.

Herkert, J.R., Sample, D.W., and Warner, R.E., 1996, Management of Midwestern grassland landscapes for the conservation of migratory birds: Pp. 89-116 in Thompson, E.R., III, ed., Management of Midwestern landscapes for the conservation of neotropical migratory birds: United States Department of Agriculture Forest Service, General Technical Report NC-187.

Horn, D.J., and Koford, R.R., 2000, Relation of grassland bird abundance to mowing of Conservation Reserve Program fields in North Dakota: Wildlife Society Bulletin, v. 28, p. 653-659.

Igl, L.D., 1991, The role of climate and mowing on dickcissel (Spiza americana) movements, distribution, and abundance: Unpublished M.S. Thesis, Iowa State University, Ames, Iowa.

James, D.A., and Neal, J.C., 1986, Arkansas birds: University of Arkansas Press, Fayetteville, Arkansas. 
Jobin, B., DesGranges, J.L., and Boutin, C., 1996, Population trends in selected species of farmland birds in relation to recent developments in agriculture in the St. Lawrence Valley: Agricultural Ecosystems and Environment, v. 57, p. 103-116.

Johnson, D.H., 2001, Habitat fragmentation effects on birds in grasslands and wetlands: a critique of our knowledge: Great Plains Research, v. 11, p. 211-231.

Johnson, D.H., and Igl, L.D., 2001, Area requirements of grassland birds: a regional perspective: Auk, v. 118, p. 24-34.

Johnson, O.W., and Ohmart, R.D., 1973, Some features of water economy and kidney microstructure in the large billed savannah sparrow (Passerculus sandwichensis rostratus): Physiological Zoology, v. 46, p. 276-284.

Jones, S.L., and Dieni, J.S., 2007, The relationship between predation and nest concealment in mixedgrass prairie passerines: an analysis using program MARK: Studies in Avian Biology, v. 34, p. 117123.

Jones, S.L., Dieni, J.S., and Gouse, P.J., 2010, Reproductive biology of a grassland songbird community in northcentral Montana: Wilson Journal of Ornithology, v. 122, p. 455-464.

Jones, Z.F., and Bock, C.E., 2002, Conservation of grassland birds in an urbanizing landscape: a historical perspective: Condor, v. 104, p. 643-651.

Kale, H.W., and Maehr, D.S., 1990, Florida’s birds: Pineapple Press, Sarasota, Florida.

Kerns, C.K., Ryan, M.R., Murphy, R.K., Thompson, F.R., and Rubin, C.S., 2010, Factors affecting songbird nest survival in northern mixed-grass prairie: Journal of Wildlife Management, v. 74, p. 257264.

Kershner, E.L., and Bollinger, E.K., 1996, Reproductive success of grassland birds at east-central Illionois airports: American Midland Naturalist, v. 136, p. 358-366.

Kirsch, L.M., Duebbert, H.F., and Kruse, A.D., 1978, Grazing and haying effects on habitats of upland nesting birds: Pp. 486-497 in Transactions of the $43^{\text {rd }}$ North American Wildlife and Natural Resources Conference, Published by the Wildlife Management Institute, Washington, D.C.

Knopf, F.L., Sedgwick, J.A., and Cannon, R.W., 1988, Guild structure of a riparian avifauna relative to seasonal cattle grazing: Journal of Wildlife Management, v. 52, p. 280-290.

Koford, R.R., 1999, Density and fledging success of grassland birds in conservation reserve program fields in North Dakota and west-central Minnesota: Studies in Avian Biology, v. 19, p. 187-195.

Koford, R.R., and Best, L.B., 1996, Management of agricultural landscapes for the conservation of neotropical migratory birds: Pp. 68-88 in Thompson, E.R., III, ed., Management of Midwestern landscapesfor the conservation of neotropical migratory birds: United States Department of Agriculture Forest Service, General Technical Report NC-187.

Kwasny, D.C., 2000, Reproductive response of savannah sparrows (Passerculus sandwichensis) to livestock grazing at Humboldt Bay National Wildlife Refuge: Unpublished M.S. Thesis, Humboldt State University, Humboldt, Oregon.

Lapointe, S., Belanger, L., Giroux, J.F., and Filion, B., 2003, Effects of plant cover improvements for nesting ducks on grassland songbirds: Canadian Field-Naturalist, v. 117, p. 167-172.

Lariviere, S., and Lepage, M., 2000, Effect of water-level increase on use by birds of a lakeshore fen in Quebec: Canadian Field-Naturalist, v. 114, p. 694-696.

Lima, S.L., and Valone, T.J., 1991, Predators and avian community organization: an experiment in a semi-desert grassland: Oecologia, v. 86, p. 105-112.

Madden, E.M., Murphy, R.K., Hansen, A.J., and Murray, L., 2000, Models for guiding management of prairie bird habitat in northwestern North Dakota: American Midland Naturalist, v. 144, p. 377-392. 
Maher, W.J., 1973, Birds: I. population dynamics: Canadian Committee for the IBP, Saskatoon, Saskatchewan.

Maher, W.J., 1979, Nestling diets of passerine birds at Matador, Saskatchewan, Canada: Ibis, v. 121, p. 437-452.

Martin, P.A., and Forsyth, D.J., 2003, Occurrence and productivity of songbirds in prairie farmland under conventional versus minimum tillage regimes: Agricultural Ecosystems and Environment, v. 96, p. 107-117.

Marx, D.E., Hejl, S.J., and Herring, G., 2008, Wintering grassland bird habitat selection following summer prescribed fire in a Texas gulf coast tallgrass prairie: Fire Ecology, v. 4, p. 46-62.

Mengel, R.M., 1965, The birds of Kentucky: American Ornithological Union, Lawrence, Kansas.

Meunier, M., and Bedard, J., 1984, Nestling foods of the savannah sparrow: Canadian Journal of Zoology, v. 62, p. 23-27.

Morgan, M.R., Norment, C., and Runge, M.C., 2010, Evaluation of a reproductive index for estimating productivity of grassland breeding birds: Auk, v. 127, p. 86-93.

Muheim, R., and Akesson, S., 2002, Clock-shift experiments with savannah sparrows, Passerculus sandwichensis, at high northern latitudes: Behavioral Ecology and Sociobiology, v. 51, p. 394-401.

Nack, J.L., and Ribic, C.A., 2005, Apparent predation by cattle at grassland bird nests: Wilson Bulletin, v. 117, p. 56-62.

Nocera, J.J., Parsons, G.J., Milton, G.R., and Fredeen, A.H., 2005, Compatibility of delayed cutting regime with bird breeding and hay nutritional quality: Agricultural Ecosystems and Environment, $\mathrm{v}$. 107, p. 245-253.

Norment, C.J., Ardizzone, C.D., and Hartman, K., 1999, Habitat relations and breeding biology of grassland birds in New York: Studies in Avian Biology, v. 19, p. 112-121.

Norment, C.J., Runge, M.C., and Morgan, M.R., 2010, Breeding biology of grassland birds in western New York: conservation and management implications: Avian Conservation and Ecology, v. 5, p. 114.

Norris, R.A., 1960, Density, racial composition, sociality and selective predation in nonbreeding populations of savannah sparrows: Bird-Banding, v. 31, p. 173-216.

Odum, E.P., and Hight, G.L., 1957, The use of mist nets in population studies of winter fringillids on the AEC Savannah River Area: Bird-Banding, v. 28, p. 203-213.

O’Leary, C.H., and Nyberg, D.W., 2000, Treelines between fields reduce the density of grassland birds: Natural Areas Journal, v. 20, p. 243-249.

Owens, R.A., and Myres, M.T., 1973, Effects of agriculture upon populations of native passerine birds of an Alberta fescue grassland: Canadian Journal of Zoology, v. 51, p. 697-713.

Patten, M.A., Erickson, R.A., and Unitt, P., 2004, Population changes and biogeographic affinities of the birds of the Salton Sea, California/Baja California: Studies in Avian Biology, v. 27, p. 24-32.

Patterson, M.P., and Best, L.B., 1996, Bird abundance and nesting success in Iowa CRP fields: the importance of vegetation structure and composition: American Midland Naturalist, v. 135, p. 153-167.

Perlut, N.G., 2007, Effects of hayfield management on grassland and songbirds: behavioral responses and population processes: Unpublished PhD Dissertation, Unversity of Vermont, Vermont, ?? pp.

Perlut, N.G., Strong, A.M., Donovan, T.M., and Buckley, N.J., 2006, Grassland songbirds in a dynamic management landscape: behavioral responses and management strategies: Ecological Applications, $\mathrm{v}$. 16, p. 2235-2247.

Perlut, N.G., Freeman-Gallant, C.R., Strong, A.M., Donovan, T.M., Kilpatrick, C.W., and Zalik, N.J., 2008a, Agricultural management affects evolutionary processes in a migratory songbird: Molecular Ecology, v. 17, p. 1248-1255. 
Perlut, N.G., Strong, A.M., Donovan, T.M., and Buckley, N.J., 2008b, Regional population viability of grassland songbirds: effects of agricultural management: Biological Conservation, v. 141, p. 31393151.

Perlut, N.G., Strong, A.M., Donovan, T.M., and Buckley, N.J., 2008c, Grassland songbird survival and recruitment in agricultural landscapes: implications for source-sink demography: Ecology, v. 89, p. 1941-1952.

Petersen, K.L., and Best, L.B., 1986, Diets of nestling sage sparrows and Brewer's sparrow in an Idaho sagebrush community: Journal of Field Ornithology, v. 57, p. 283-294.

Pietz, P.J., and Granfors, D.A., 2000, Identifying predators and fates of grassland passerine nests using miniature video cameras: Journal of Wildlife Management, v. 64, p. 71-87.

Posadas-Leal, C., Chapa-Vargas, L., Arredondo-Moreno, J.T., and Huber-Sannwald, E., 2010, Effects of habitat type on bird nesting in the desert grasslands of central Mexico: conservation implications: Oryx, v. 44, p. 448-454.

Potter, P.E., 1974, Breeding behavior of savannah sparrows in southeastern Michigan: Jack-Pine Warbler, v. 52, p. 50-63.

Powell, A.N., 1993, Nesting habitat of Belding savannah sparrow in coastal salt marshes: Wetlands, v. 13, p. 219-223.

Prescott, D.R.C., and Murphy, A.J., 1999, Bird populations of seeded grasslands in the Aspen Parkland of Alberta: Studies in Avian Biology, v. 19, p. 201-210.

Pylypec, B., 1991, Impacts of fire on bird populations in a fescue prairie: Canadian Field-Naturalist, v. 105, p. 346-349.

Rae, L.F., Mitchell, G.W., Mauck, R.A., Guglielmo, C.G., and Norris, D.R., 2009, Radio transmitters do not affect the body condition of savannah sparrows during the fall premigratory period: Journal of Field Ornithology, v. 80, p. 419-426.

Renfrew, R.B., and Ribic, C.A., 2001, Grassland birds associated with agricultural riparian practices in southwestern Wisconsin: Journal of Range Management, v. 54, p. 546-552.

Renfrew, R.B., and Ribic, C.A., 2002, Influence of topography on density of grassland passerines in pastures: American Midland Naturalist, v. 147, p. 315-325.

Renfrew, R.B., and Ribic, C.A., 2003, Grassland passerine nest predators near pasture edges identified on videotape: Auk, v. 120, p. 371-383.

Renfrew, R.B., Ribic, C.A., and Nack, J.L., 2005, Edge avoidance by nesting grassland birds: a futile strategy in a fragmented landscape: Auk, v. 122, p. 618-636.

Ribic, C.A., and Sample, D.W., 2001, Associations of grassland birds with landscape factors in southern Wisconsin: American Midland Naturalist, v. 146, p. 105-121.

Ribic, C.A., Guzy, M.J., and Sample, D.W., 2009, Grassland bird use of remnant prairie and Conservation Reserve Program fields in an agricultural landscape in Wisconsin: American Midland Naturalist, v. 161, p. 110-122.

Robinson, M.B., and Easterla, D.A., 1992, Birds of Missouri: University of Missouri Press, Columbia, Missouri.

Rodenhouse, N.L., Best, L.B., O’Conner, R.J., and Bollinger, E.K., 1995, Effects of agricultural practices and farmland structure: Pp. 269-293 in Martin, T.E., and Finch, D.M., eds., Population ecology and conservation of neotropical migrant birds, Oxford University Press, New York, New York.

Ryser, F., 1985, Birds of the Great Basin: University of Nevada Press, Reno, Nevada.

Sanders, T.A., and Edge, W.D., 1998, Breeding bird community composition in relation to riparian vegetation structure in the western United States: Journal of Wildlife Management, v. 62, p. 461-473. 
Sauer, J.R., Hines, J.E., Fallon, J.E., Pardieck, K.L., Ziolkowski, D.J., Jr., and Link, W.A., 2011, The North American Breeding Bird Survey, Results and Analysis 1966 - 2009: Version 3.23.2011. Online at http://www.mbr-pwrc.usgs.gov/bbs/bbs.html. Accessed on 12 July 2011.

Scheiman, D.M., Bollinger, E.K., and Johnson, D.H., 2003, Effects of leafy spurge infestation on grassland birds: Journal of Wildlife Management, v. 67, p. 115-121.

Schmidt, M.H., Lefebvre, G., Poulin, B., and Tscharntke, T., 2005, Reed cutting affects arthropod communities, potentially reducing food for passerine birds: Biological Conservation, v. 121, p. 157166.

Shustack, D.P., Strong, A.M., and Donovan, T.M., 2010, Habitat use patterns in bobolinks and savannah sparrows in the northeastern United States: Avian Conservation and Ecology, v. 5, p. 1-18.

South Dakota Ornithologists' Union, 1991, The birds of South Dakota, $2^{\text {nd }}$ edition: South Dakota Ornithologists’ Union, Aberdeen, South Dakota.

Speirs, J.M., 1985, Birds of Ontario: Natural Heritage/Natural History, Toronto.

Stobo, W.T., and McLaren, I.A., 1975, The Ipswich sparrow: Proceedings of the Nova Scotia Scottish Institute of Science, v. 27, p. 1-105.

Thompson, T.R., Boal, C.W., and Lucia, D., 2009, Grassland bird associations with introduced and native grass Conservation Reserve Program fields in the southern high plains: Western North American Naturalist, v. 69, p. 481-490.

Toolen, J.F., 1998, Savannah sparrow, Passerculus sandwichensis: Pp. 470-471 in Kingery, H.E., ed., Colorado Breeding Bird Atlas, Colorado Bird Atlas Partnership, Copublished by Colorado Division of Wildlife, Denver, Colorado.

Tufts, R.W., 1986, Birds of Nova Scotia, $3^{\text {rd }}$ edition: Nova Scotia Museum, Halifax, Nova Scotia. Unitt, P., 1984, The birds of San Diego County: San Diego Society of Natural History Memoirs i-xxii, 1-276.

Vickery, J.A., Tallowin, J.R., Feber, R.E., Asteraki, E.J., Atkinson, P.W., Fuller, R.J., and Brown, V.K., 2001, The management of lowland neutral grasslands in Britain: effects of agricultural practices on birds and their food resources: Journal of Applied Ecology, v. 38, p. ?-?

Vos, S.M., and Ribic, C.A., 2011, Grassland bird use of oak barrens and dry prairies in Wisconsin: Natural Areas Journal, v. 31, p. 26-33.

Walk, J.W., and Warner, R.E., 1999, Effects of habitat area on the occurrence of grassland birds in Illinois: American Midland Naturalist, v. 141, p. 339-344.

Warren, K.A., and Anderson, J.T., 2005, Grassland songbird nest-site selection and response to mowing in West Virginia: Wildlife Society Bulletin, v. 33, p. 285-292.

Watts, B.D., 1990, Cover use and predator-related mortality in song and savannah sparrows: Auk, v. 107, p. 775-778.

Watts, B.D., 1996, Landscape configuration and diversity hotspots in wintering sparrows: Oecologia, v. 108, p. 512-517.

Wells, J.V., and Rosenberg, K.V., 1999, Grassland bird conservation in northeastern North America: Studies in Avian Biology, v. 19, p. 72-80.

Welsh, D.A., 1975, Savannah sparrow breeding territoriality on a Nova Scotia dune beach: Auk, v. 92, p. 235-251.

Wheelwright, N.T., and Beagley, J.C., 2005, Proficient incubation by inexperienced savannah sparrows, Passerculus sandwichensis: Ibis, v. 147, p. 67-76.

Wheelwright, N.T., and Rising, J., 1993, Savannah sparrow (Passerculus sandwichensis): American Ornithologists’ Union, Washington, D.C. 
Wheelwright, N.T., and Rising, J.D., 2008, Savannah sparrow (Passerculus sandwichensis): Poole, A., ed., The Birds of North America Online, Ithaca, Cornell Lab of Ornithology, Retrieved from the Birds of North America Online, http://bna.birds.cornell.edu/bna/species/045. Accessed 1 July 2011.

Wheelwright, N.T., Lawler, J.J., and Weinstein, J.H., 1997, Nest-site selection in savannah sparrows: using gulls as scarecrows?: Animal Behaviour, v. 53, p. 197-208.

Wheelwright, N.T., Schultz, C.B., and Hodum, P.J., 1992, Polygyny and male parental care in savannah sparrows: effects of female fitness: Behavioral Ecology and Sociobiology, v. 31, p. 279-289.

Wiens, J.A., 1969, An approach to the study of ecological relationships among grassland birds: Ornithological Monographs, v. 8, p. 1-93.

Williams, J.B., 1985, Validation of the doubly labeled water technique for measuring energy metabolism in starlings and sparrows: Comparative Biochemistry and Physiology - Part A: Physiology, v. 80, p. 349-353.

Williams, J.B., 1987, Field metabolism and food consumption of savannah sparrows during the breeding season: Auk, v. 104, p. 277-289.

Williams, J.B., and Dwinnel, B., 1990, Field metabolism of free-living female savannah sparrows during incubation: a study of doubly labeled water: Physiological Zoology, v. 63, p. 353-372.

Winter, M., Johnson, D.H., Shaffer, J.A., and Svedarsky, W.D., 2004, Nesting biology of three grassland passerines in the northern tallgrass prairie: Wilson Bulletin, v. 116, p. 211-223.

Winter, M., Johnson, D.H., and Shaffer, J.A., 2005, Variability in vegetation effects on density and nesting success of grassland birds: Journal of Wildlife Management, v. 69, p. 185-197.

Winter, M., Johnson, D.H., Shaffer, J.A., Donovan, T.M., and Svedarsky, W.D., 2006, Patch size and landscape effects on density and nesting success of grassland birds: Journal of Wildlife Management, v. 70, p. 158-172.

Wray, T., Strait, K.A., and Whitmore, R.C., 1982, Reproductive success of grassland sparrows on a reclaimed surface mine in West Virginia: Auk, v. 99, p. 157-164.

Zalik, N.J., 2007, Effects of agricultural management on breeding Savannah Sparrows (Passerculus sandwichensis) mediated through food availability: Unpublished M.S. Thesis, University of Vermont, Vermont.

Zalik, N.J., and Perlut, N.G., 2008, Simultaneous incubation by two females and nestling provisioning by four adults at a savannah sparrow nest: Wilson Journal of Ornithology, v. 120, p. 628-630.

Zuckerberg, B., and Vickery, P.D., 2006, Effects of mowing and burning on shrubland and grassland birds on Nantucket Island, Massachusetts: Wilson Journal of Ornithology, v. 118, p. 353-363. 


\section{Northern Leopard Frog [Lithobates (=Rana) pipiens]}

\section{Introduction}

The northern leopard frog [Lithobates (=Rana) pipiens] is a widespread species that has experienced significant declines across most of its range, while remaining abundant in some areas (Smith and Keinath 2007). [For the remainder of this section, I will use the abbreviation NLF for the northern leopard frog.] In the Rocky Mountain region, which includes U.S. Fish and Wildlife Service Region 6, Colorado and Montana legally protect the species and the

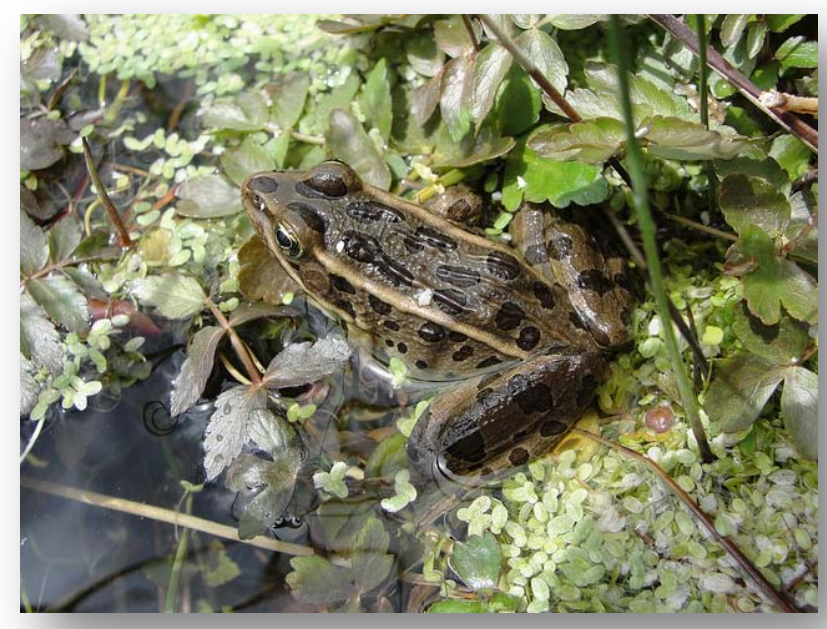

Northern Leopard Frog, courtesy of Laurie Averill-Murray, U.S. Fish and Wildlife Service, Pacific Southwest Region. USDA Forest Service (USFS) Rocky Mountain Region (Region 2) has listed the NLF as a sensitive species. In 2009, the USFWS announced a 90-day finding on a petition to list the western population of the NLF as federally threatened under the Endangered Species Act of 1973 (U.S. Fish and Wildlife Service 2009). The petition provided substantial information suggesting that the western population is genetically distinct from the eastern NLF (Hoffman and Blouin, 2004). The NLF is experiencing threats from habitat loss, disease, nonnative species, pollution and climate change that individually and cumulatively have resulted in population declines, local extinctions, and disappearance from vast areas of its historical range in the western United States and Canada (U.S. Fish and Wildlife Service 2009). The 90-day finding indicated that listing of the western population of the NLF may be warranted.

There is a large amount of literature available on the NLF and it is one of the best known frogs in North America. A simple Google search on the Internet for "Lithobates and Rana pipiens" revealed 257,000 results and a Google Scholar search provided 16,200 results (accessed 6 June 2011). "Northern leopard frog” revealed 237,000 results through Google and 2,180 results through Google Scholar (accessed 6 June 2011).

\section{Natural History}

\section{Morphological Characteristics}

The NLF is a medium-sized ranid with a maximum snout-vent length (SVL) of $11 \mathrm{~cm}$ (Hammerson, 1999). It has a green or brown dorsum with large rounded or oval spots, the skin is smooth, the eardrum usually lacks a distinct light spot, the hind legs are powerful and it has extensively webbed hind feet that are well adapted for jumping and swimming (Pace, 1974). It is also characterized by conspicuous dorsolateral ridges bordering the spots at the edge of the dorsum (Smith and Keinath, 2007). Males have swollen thumbs on their forefeet during the breeding season and paired vocal pouches at the sides behind the head, which are visible when vocalizing. Males are also typically smaller than females (Smith and Keinath, 2007). Tadpoles of most frogs are difficult to identify without a dissecting microscope and expert advice. The tadpoles of this species are brown, olive, or gray with the snout pointed in the dorsal view (Hammerson, 1999). The maximum tail length for tadpoles in Colorado is $10 \mathrm{~cm}$ (Hammerson, 1999). The eggs of NLFs are black from above, whitish from below, with a diameter averaging 1.3-2.3 mm. Eggs are typically enclosed in 2-3 jelly envelopes and deposited 
in large, somewhat flattened globular masses 5-15 cm in maximum diameter that include up to several thousand eggs (Hammerson, 1999).

\section{Distribution and Abundance}

NLFs are widely distributed in North America, from southern Canada and the northern United States south to Maryland, West Virginia, Kentucky, northern Illinois, extreme northwestern Missouri, Nebraska, New Mexico, Arizona, and eastern California (Conant and Collins, 1998; Hammerson, 1999; Stebbins, 2003). NLFs occur throughout Colorado, excluding most of the southeastern and east-central portions of the state (Hammerson, 1999). Their elevational range extends from 1,065 $\mathrm{m}$ in northeastern Colorado to above 3,355 $\mathrm{m}$ in southern Colorado (Hammerson, 1999).

The NLF was formerly abundant across its entire range, but has since suffered wide-ranging population declines (Smith and Keinath, 2007). Particularly in the western United States, the species has undergone major declines and suffered extirpations in some areas (Rorabaugh, 2005). Generally, it is thought that eastern populations are in somewhat better condition than western populations (Smith and Keinath, 2007). In Colorado, NLFs have become scarce in many areas and some populations have disappeared due partly to changes in habitat (Hammerson, 1999). Suitability of breeding sites can change in response to climatic variation and flooding, though some sites may be created by these events. In Larimer County, Colorado, from 1973 to 1982, Corn and Fogelman (1984) documented the extirpation of nine populations at elevations from 2,365 to 2,520 m. Six of these nine populations disappeared due to drought-related drying of breeding ponds and the other three may have been extirpated due to random events that can befall small populations. Local extirpations and recolonizations are most likely common features in the ecology of the NLF in the drought-prone climate of Colorado (Hammerson, 1999); however, some disappearances in Colorado, especially along the Front Range, do not have an adequate explanation (Corn and others, 1989; 1997; Hammerson, 1989; 1992; Livo, 1995).

Some reduced or extirpated NLF populations in lowland areas of Colorado are associated with the presence of the increasingly abundant bullfrog (Rana catesbeiana) (Hammerson, 1982). Purposeful introductions of bullfrogs to Colorado began in the 1900s into the South Platte River drainage; since that time bullfrogs have been reported from 30 of Colorado's 63 counties (Livo and others, 1998). NLFs are now greatly outnumbered by bullfrogs in many streams, ponds, reservoirs, and wetland areas, especially in eastern Colorado. In some areas, human alterations of wetlands have increased water depth and permanence, resulting in the replacement of NLF by bullfrogs and fishes, especially near large rivers and other permanent bodies of water (Hammerson, 1999). Sites in eastern Colorado where NLFs occur in greatest abundance are small, relatively isolated reservoirs that have not been colonized by bullfrogs or predatory fish. Lannoo and others (1994) conducted a survey of native amphibian species in Iowa and concluded that bullfrogs were the most immediate threat to existing populations of native amphibians. In Ontario, Hecnar and M’Closkey (1997b) found significant changes in ranid relative abundance after a bullfrog extinction and concluded that bullfrogs are important in structuring amphibian communities through direct predation and competition for resources.

Hecnar and M'Closkey (1997a) also examined the effects of predatory fish on amphibian communities in Ontario. They found that amphibian species richness was significantly lower at ponds having predatory fish present than at nonpredatory, or fish-free, ponds. Numbers of NLFs also occurred in proportionately more nonpredatory fish ponds because NLF larvae are palatable to fish, unlike bullfrog larvae, which are unpalatable to fish (Kats and others, 1988). Nonnative predatory fish were also implicated in the decline of the Cascades frog (Rana cascadae) in Lassen Volcanic National Park, California. The introduction of nonnative fish has eliminated local amphibian populations in many parts 
of North America (Hayes and Jennings, 1986; Sexton and Phillips, 1986; Bradford, 1989; Liss and Larson, 1991).

Declines of NLFs in lowland areas of Colorado are not always attributable to predation by bullfrogs or fish. Flood control measures and diversion of water for irrigation probably have reduced the availability of breeding habitat along floodplains in the lowland segments of some streams (Hammerson, 1999). Additionally, although NLFs have disappeared from many natural breeding sites in Colorado, they still occur in many human-created habitats, both in the lowlands and in the mountains. It is unknown how natural habitat loss has been offset by the addition of artificial habitat for this species.

\section{Habitat}

Because NLFs have a complicated life history, they require a broad range of habitats in close proximity. Three categories of major habitat type were described by Merrell and Rodell (1968): winter habitat (overwintering in lakes, streams, and ponds); summer habitat (feeding by adults in upland areas); and, tadpole habitat (up to three months spent as tadpoles in shallow breeding ponds). Their complicated movement patterns during the year should also be considered (Smith and Keinath, 2007). Relevant literature found describing NLF habitat comes from populations scattered across North America. Therefore, it is likely that there are differences in habitat use regionally.

Typical habitats of NLFs described in Colorado include wet meadows and the banks and shallows of marshes, ponds, glacial kettle ponds, beaver ponds, lakes, reservoirs, streams, and irrigation ditches (Hammerson, 1999). Adult NLFs are usually found at the water's edge, but they may roam far from permanent water during mild wet weather. Winter months are spent at the bottom of water bodies such as ponds and streams. Cunjak (1986) observed NLFs hibernating in a Canadian river in winter beneath the rubble, generally where the water depth was greater than $85 \mathrm{~cm}$. The frogs were torpid, but capable of swimming. Emery and others (1972) observed NLFs hibernating in ice-covered ponds in Ontario, Canada. The frogs were resting in small excavated pits, lightly covered with silt, and capable of some movement including swimming.

\section{Activity and Movement Patterns}

In the plains region of Colorado, NLFs typically emerge from their winter retreats in March (Hammerson, 1999). The frogs are then active until October or November, when the colder temperature forces them into torpor, or dormancy. However, frogs have been found to be active in January and February in the San Luis Valley (SLV) at pools formed by discharge of warm artesian wells (Hahn, 1968). NLFs can move long distances. Gillis (1975) marked a frog in a pond in Cheyenne County, Colorado, and found the same individual $3 \mathrm{~km}$ away at another pond the following year.

Dole (1965) studied movement patterns of adult NLFs in Michigan by trailing individuals with a spool of thread. This study found that the adult frogs are rather sedentary and generally confined their activities to relatively limited areas (within 5-10 m), but on rainy nights, individuals embarked on excursions that would involve distances of more than $100 \mathrm{~m}$ across habitats not usually inhabited by frogs. Conversely, newly metamorphosed NLFs in Michigan would disperse much further, commonly traveling up to $800 \mathrm{~m}$ in a few days (Dole, 1971). Climatic variables such as precipitation or minimum air temperatures are generally good predictors of amphibian activity (Mazerolle, 2001).

Mazerolle and Desrochers (2005) examined landscape resistance to NLF movements in New Brunswick and found that 72 percent of frogs avoided disturbed surfaces and lost the most water on substrates associated with disturbance. They concluded that anthropogenically disturbed areas devoid of cover, such as agricultural fields, disrupt the ability of frogs to reach habitat patches and are a likely explanation for the reduced abundance of frogs in agricultural areas. 


\section{Reproduction and Growth}

NLFs breed in shallow, quiet areas of permanent bodies of water, in beaver ponds, and in seasonally flooded areas adjacent to or contiguous with permanent pools or streams (Hammerson, 1999). Breeding areas contain vegetation, mats of algae, and clear water. At lower elevations in Colorado, males begin calling on warm, sunny days in March or April. Males will call while floating on the surface of the water and will frequently wrestle with other males between calling bouts.

Females begin laying eggs a few days after calling begins (Hammerson, 1999). In the plains region of Boulder County, Colorado, most females lay their eggs by mid-April, sometimes by the end of March if warm weather arrives early. Along the Arkansas River in Pueblo County, Post (1972) found that the breeding season can be variable from year to year (April 15 to May 20, April 24 to May 7, and April 12 to May 16 in consecutive years). Females produce only one clutch per season (Hammerson, 1999).

Egg masses are attached to vegetation just below the surface of warm shallows about 7 to $25 \mathrm{~cm}$ deep. At elevations of 1,570 to 2,520 $\mathrm{m}$ in Colorado and southern Wyoming, egg masses average about 3,000 eggs (range 645-6,272) (Corn and Livo, 1989). There does not appear to be a relationship between clutch size and elevation. In the plains region of Boulder County, eggs hatch in 4-15 days (Livo, 1981). Egg masses deposited in late March are often covered with tiny hatchlings by mid-April (Hammerson, 1999). Early clutches may hatch before later clutches are deposited (Livo, 1981). Newly metamorphosed individuals have been found in late June and early July (Hammerson, 1999). Frogs do not begin to breed until their second spring. In the SLV, calling may continue until late June (Hammerson, 1999). Hahn (1968) observed newly metamorphosed individuals in the SLV on July 24.

\section{Food Habits}

There is little information on the food habits of the NLF in Colorado; however, invertebrates most likely dominate the diet of adult frogs (Hammerson, 1999). Gehlback (1965) reported that NLFs ate tenebrionid beetles in northwestern New Mexico. Drake (1914) studied the food habits of NLFs in Ohio and found that the diet consisted of molluscs, crustaceans, spiders, and insects. Hendricks (1973) investigated the intestinal contents of NLF tadpoles in Mexico and found 10 genera of algae that could be positively identified and concluded that tadpoles are filter feeders on free-floating algae suspended in the aquatic environment.

\section{Predators}

Predators of NLFs vary depending on the stage of their life history. Known predators on larvae in Colorado include pied-billed grebes (Podilymbus podiceps) (Hammerson, 1999) and tiger salamanders (Ambystoma tigrinum) (Corn, 1981). Garter snakes (Thamnophis radix) were reported to predate larvae in western Nebraska (Ballinger and others, 1979). Predators on metamorphosed individuals in Colorado include the great blue heron (Ardea herodias) (Hammerson, 1999), burrowing owl (Athene cunicularia) (Hamilton, 1941), northern water snake (Nerodia sipedon), and western terrestrial garter snake (Thamnophis elegans) (Cockerell, 1910; Hammerson, 1999). Adults and larvae are also vulnerable to predation by various game and nonnative predatory fishes, as previously noted (Bagdonas, 1968). Eggs and small larvae are most likely vulnerable to predation by bullfrog larvae based on experiments with the plains leopard frog (Rana blairi) (Ehrlich, 1979). 


\section{Threats}

There are extrinsic and intrinsic threats to NLF populations in the Rocky Mountain region. Extrinsic threats can fall into three main categories: 1) landscape-scale processes that threaten the viability of populations; (2) direct threats of mortality from various nonindigenous biotic agents; and, (3) water quality issues (Smith and Keinath, 2007). Intrinsic factors considered a threat to NLF populations are those factors related to their unique habitat use requirements, reproductive biology, and physiology.

\section{Extrinsic Threats}

\section{Landscape-level Processes}

Landscape-scale changes such as loss and fragmentation of breeding habitat, disruption of migratory pathways, and loss or alteration of over-wintering sites, may have caused range-wide declines in NLFs (Smith and Keinath, 2007). Habitat loss and fragmentation in the Rocky Mountain region are caused by a variety of land uses, including urbanization and growth of suburbs, logging, recreation, and building of roads and trails (Smith and Keinath, 2007). In the mid-1950s there were an estimated 44 million hectares of wetlands in the lower 48 states (Frayer and others, 1983; Tiner, 1984). In just 20 years, these wetlands were reduced to 40 million hectares (Tiner, 1984), and this trend has continued into this century despite a national policy of no net loss of wetlands through mitigation measures (Turner and others, 2001).

Human development of wildlands has shown to negatively affect amphibian populations at a regional scale (for example, Hecnar and McCloskey, 1996). In Minnesota glacial ponds, amphibian species richness at ponds declined with distance to other ponds and with increased road density, both common results of urbanization (Lehtinen and others, 1999). Trombulak and Frissell (2000) conducted a review of the effects of roads on terrestrial and aquatic communities and found that roads of all kinds have seven general effects: mortality from road construction, mortality from collision with vehicles, modification of animal behavior, alteration of the physical environment, alteration of the chemical environment, spread of exotics, and increased use of areas by humans. Roads affect amphibian populations most obviously by eliminating or altering migration and dispersal corridors, but also directly through road mortality or simply by damaging habitat (Smith and Keinath, 2007). Herpetologists are well aware of the negative affect of roads on amphibians because they frequently use roads to survey their target organisms (Shaffer and Juterbock, 1994). Roads located too close to wetlands have been known to reduce populations of salamanders (Semlitsch, 1998). It has been known for some time that roads cause extensive mortality of juvenile NLFs (Bovbjerg, 1965; Bovbjerg and Bovbjerg, 1964; Merrell, 1977). Ashley and Robinson (1996) found that young-of-the-year NLFs were disproportionately represented among dead herpetofauna on roads at their study site in Ontario. Road runoff can also be a source of environmental pollution, and can significantly threaten nearby aquatic habitats (Welsh and Oliver, 1998; Trombulak and Frissell, 2000; Dorchin and Shanas, 2010). NLFs are more vagile than other species of frogs and this could be a disadvantage in landscapes with roads because they are more likely to encounter roads and incur traffic mortality (Carr and Fahrig, 2001). In Ontario, NLF population density was found be negatively affected by traffic density within a radius of $1.5 \mathrm{~km}$ whereas compared with a less vagile frog, the green frog (Rana clamitans), there was no evidence that the presence of vehicular traffic affected their populations (Carr and Fahrig, 2001).

Climate factors, such as drought, also can have a major influence on NLF populations (Merrell, 1977; Corn and Fogleman, 1984; Koch and others, 1996). In drought years, habitat for frogs will decline and local populations may be extirpated. Drought conditions were associated with a decline in 
amphibian populations in southern Alberta in the 1930s (Fowler, 1935). Drought conditions were also prevalent in southern Alberta in the late 1970s and 1980s, suggesting a possible link between climatic conditions and the abrupt decline of this species in Alberta beginning in the late 1970s (Alberta Northern Leopard Frog Recovery Team, 2011). There is clear evidence that the number of Growing Degree Days (GDD) have increased significantly in the SLV, indicating climate is changing disproportionately during the growing season (Mix and others, 2010). This could potentially lead to more drought conditions in the SLV in the future, which would negatively affect NLF populations.

Increasing ultraviolet (UV) radiation from a thinning ozone layer has also been linked with declines in amphibian populations and with increased incidence of limb malformations (Crump and others, 2000; Ankley and others, 2002; Blaustein and others, 2003). Embryo mortality has been attributed to UV radiation in the genus Rana (Blaustein and others, 2003). NLFs lay their eggs close to the water surface, which could potentially increase their susceptibility to UV radiation. UV radiation may also reduce resistance to disease and pathogens. UV radiation and contaminants may interact with one another synergistically and enhance the detrimental effects to amphibians (Blaustein and others, 2003). Bridges and others (2004) found that the presence of the contaminants atrazine and carbaryl, and the interaction with UV radiation increased the incidence of hatchling deformities. Ankley and others (1998) examined the effects of UV light and the insecticide methoprene on the survival and development of NLFs. They were able to induce relatively specific hindlimb malformations in frogs by treatment with UV light, but that methoprene treatments both in the absence and presence of UV, did not result in limb abnormalities. Croteau and others (2008) also looked at exposure of NLF tadpoles to UV-B radiation and an estrogenic chemical 4-tert-octylphenol (OP), both alone and in combination. UV-B radiation alone was sufficient to produce mortality of tadpoles, and exposure to UV-B radiation or OP alone induced significant increase in malformations and abnormalities of tadpoles (Croteau and others, 2008).

Oil and gas development threatens the NLF and its habitat (Center for Native Ecosystems, 2006). Federal land management agencies, including the Bureau of Land Management (BLM) and the U.S. Forest Service (USFS), have determined that oil and gas development in areas of Colorado, Montana, New Mexico, and Wyoming, including the drilling and maintenance of wells, related construction of roads, and disposal of wastes, will negatively affect the NLF (Center for Native Ecosystems, 2006). The USFS concluded that coal-bed methane development in Wyoming will negatively affect the NLF and its habitat in several areas of Thunder Basin National Grassland (USFS 2004a; 2004b; 2004c). Impacts associated with coal-bed methane development include road-related mortality, discharge of contaminated water into breeding ponds, the loss of spring flows due to massive groundwater removal, discharge of excessively cold water into breeding ponds, and discharge of water that may facilitate the introduction of predatory fish (Powder River Basin Resource Council, 2002). In general, coal-bed methane development, in which massive amounts of groundwater are removed and later discharged at the surface, is detrimental to aquatic systems that may support the NLF and has negatively affected aquatic systems supporting the western United States population of NLF (Powder River Basin Resource Council, 2002). Other areas where oil and gas development is reported to be negatively affecting or threatening to negatively affect the western population of NLF and its habitat include La Plata and Archuleta Counties in southwestern Colorado, Big Horn, Blaime, Carbon, Custer, Gallatin, Musselshell, Park, Powder River, Rosebud, Stillwater, Sweetgrass, Treasure, and Yellowstone Counties in Montana, and Carbon County, Wyoming (Center for Native Ecosystems, 2006). Oil and gas development in these areas will adversely affect the NLF and its habitat by directly disturbing the species and its habitat, indirectly altering local hydrology, by introducing contaminants into waters, and by reducing the availability of water for the species. Oil field development may also be contaminating 
NLF habitats in Wyoming (Ramirez, 2002). A majority of oil field discharge samples were found to exceed the state of Wyoming water quality standards for oil and grease. In Colorado, oil and gas development also threatens NLF populations in the Roan Plateau region (Center for Native Ecosystems, 2006).

Agriculture strongly dominates the landscapes of some regions of the United States, including the SLV (Mix and others, 2010). Agricultural practices have a potentially large negative influence on amphibian populations because of the attendant habitat loss, isolation, and chemical and nutrient contamination (Bishop and others, 1999; Kolozsvary and Swihart, 1999; Zampella and Bunnell, 2000; Joly and others, 2001). Chemical and nutrient contamination is a serious threat to NLFs and is discussed in more detail under the "Water Quality" section below. However, in regions where natural wetlands are scarce, constructed agricultural ponds may represent important alternative breeding habitats for amphibians (Baker and Halliday, 1999). If properly managed, agricultural ponds may effectively increase the total amount of breeding habitat in a region and help to sustain populations (Meyer-Aurich and others, 1998; Pechmann and others, 2001).

Nonindigenous Biotic Agents

The effects of introduced organisms on amphibians has been extensively documented. The potential negative effects of introduced predaceous fish and bullfrogs on NLF populations have already been discussed in a previous section. The impact of diseases to NLFs is also relevant to this review. Chytridiomycosis, caused by the bacterium Batrachochytrium dendrobatidis $(B d)$, has been recognized as a threat to the persistence of amphibian populations and is causing population declines in many frog species (Berger and others, 1998; Rollins-Smith and others, 2002; Longcore and others, 2007). Chytrid fungi are ubiquitous and found in aquatic and moist habitats where they degrade cellulose, chitin, and keratin. In amphibians, the chytrid fungi degrades the keratin component of the skin, leading to excessive keratin production and sloughing of the skin (Berger and others, 1999), which can impair cutaneous respiration and osmoregulation and result in death (Berger and others, 1998). There appears to be considerable variation among and within species in their susceptibility to the disease (Blaustein and others, 2005; Daszak and others, 2004). Voordouw and others (2010) studied the prevalence of $B d$ in an endangered population of NLFs in British Columbia and concluded that prevalence appeared to have stabilized in the last three years of the study, young of the year emerging from breeding ponds were rarely infected with $B d$, and some individuals cleared their $B d$ infection. These findings indicated that NLFs may have evolved a resistance to chytrid-related mortality in this particular location. Generally, ranid frogs should have a natural deterrent to chytrid infection in natural antimicrobial peptide defenses (Rollins-Smith and others, 2002). However, environmental factors, such as cold temperatures, UV-B or toxic chemicals may inhibit peptide synthesis and release, thereby allowing the chytrid fungus to survive and eventually kill amphibians (Rollins-Smith and others, 2002).

Infections by certain bacteria (most commonly Aeromonas hydrophilia) results in a condition referred to as "red-leg" that is nearly always fatal. This infection affects the kidneys and other organs of frogs and appears to be triggered by factors such as stress, injury, malnourishment or environmental conditions such as poor water quality (Nace and others 1996; Kendell, 2002a). Mortality and apparent population declines in NLFs have previously been associated with "red-leg” in North America (Gibbs and others, 1971; Hine and others, 1981; Koonz, 1992).

Viral infections such as Ranavirus and Herpesvirus have also been noted in NLFs and may contribute to mortality of adults or embryos (McKinnell, 1973; Hunter and others, 1989; Green and others, 2002; Echaubard and others, 2010). In a review of 20 amphibian morbidity events from 19962001, Green and others (2002) found that the most common cause of amphibian mortality was infection 
by Ranaviruses. Mortality events from Ranaviruses affected predominately larval amphibians, were observed primarily in late spring and summer, had a sudden onset, and casualties numbered in the scores to thousands of amphibians daily (Green and others, 2002). Echaubard and others (2010) found density was a primary factor determining the direction of the interaction between NLF tadpoles and Ranavirus. They found higher mortality, earlier death rates, longer development rates, and growth rates significantly lower in high-density situations when exposed to Ranaviruses.

Declines in amphibians may be due to a variety of environmental factors, not just the disease pathogen. For example, Brodkin and others (1992) found that a naturally occurring bacteria, Pseudomonas aeruginosa, was pathogenic only for NLFs under suboptimal environmental conditions. Their results suggested that there was an interaction between crowding of individuals, temperature, and bacteria on mortality. It is also hypothesized that multiple environmental stressors (for example, temperature extremes, increase UV radiation, exposure to heavy metals and toxins) may be synergistically compromising the response of amphibian immune systems (Carey and others, 1999).

Water Quality

Amphibians are particularly susceptible to ecotoxicological agents because of their complex life cycle and the permeability of their skin (Cooke, 1981; Duellman and Trueb, 1986; Bishop, 1992; Hall and Henry, 1992). There has been extensive work on the effects of water quality on NLFs. A simple Google Scholar literature search revealed more than 1,700 citations with the keywords NLF and water quality. I focus the summary of this literature on those hazards that appear to be of most concern in the Rocky Mountain region and the SLV complex of Refuges. I list below the 10 main factors contributing to poor water quality in wetland habitats frequented by NLFs (Smith and Keinath, 2007):

\section{(1) Pesticides}

Pesticides are the most studied classes of ecotoxicological agents that can affect amphibians, and specifically NLFs (Sparling and others, 2010). Various pesticides are used across the Rocky Mountain region including 2,4-D Amine, Escort ${ }^{\circledR}$, Plateau ${ }^{\circledR}$, and Roundup ${ }^{\circledR}$ to name a few. Many of the most common pesticides used currently are supposed to be nonpersistent and have short half-lives, usually from one week to 30 days (Wauchope and others, 1992), unlike more persistent pesticides used in the past (for example, organochlorines). However, year-round detections of low pesticide concentrations in streams draining from agricultural and urban areas in Colorado could indicate that these compounds persist in the shallow alluvial aquifer year-round (Kimbrough and Litke, 1996). Pesticides have been shown to cause direct mortality, hermaphrodism, limb malformations, lower survival rates, alter behavior of tadpoles, disrupt hormone production and impair reproductive potential, and suppress immune systems. Below I discuss a selection of studies that have examined pesticides used and studied in relation to NLFs in various parts of North America.

- Berrill and others $(1993 ; 1994 ; 1997)$ studied various pesticides commonly used in agriculture and silviculture in Canada. They found that the pyrethroid insecticides permethrin and fenvalerate did not cause significant mortality in NLF eggs or tadpoles exposed to low levels of these insecticides (Berrill and others, 1993). However, tadpole growth was delayed following exposure, and tadpole larvae twisted abnormally instead of darting away when being prodded by investigators. Both of these results indicated a greater vulnerability to predation. Berrill and others (1994) also studied the effects of pesticides used to manage coniferous forests in Canada on NLF embryos and tadpoles. They exposed embryos and tadpoles to low levels of the insecticide fenitrothion and the herbicides triclopyr and hexazinone. None of these pesticides affected hatching success or subsequent behavior in tadpoles that were exposed. However, newly 
hatched tadpoles were very sensitive to the concentrations used in the study (2.4 to $4.8 \mathrm{ppm}$ triclopyr and 4.0 to 8.0 ppm fenitrothion), exhibiting paralysis or death (Berrill and others, 1994). NLFs were exposed to low levels of insecticides permethrin, fenvalerate, and fenitrothion and the herbicides hexazinone, triclopyr, glyphosate, bromoxynil, triallate, and trifluralin, all of which are used in the management of coniferous forests in Canada (Berrill and others, 1997). Embryos were unaffected by the exposures, but newly hatched tadpoles were paralyzed or killed. Of those listed herbicides, glyphosate is the active ingredient in Roundup ${ }^{\circledR}$ and is the most widely used herbicide in the United States (Grube and others, 2011). Relyea (2005) also examined the impact of Roundup ${ }^{\circledR}$ on the survival of tadpoles and found that when using realistic exposure times (longer than a few days) combined with the frequently occurring stress of predators found in natural communities, Roundup ${ }^{\circledR}$ had the potential to kill many species of amphibians, including the NLF.

- Harris and others (1998) examined the effects of a combination of six pesticides commonly applied in apple orchards to premetamorphic NLFs. They found that Basudin ${ }^{\circledR}$ and Dithane ${ }^{\circledR}$ at environmentally relevant concentrations $(<0.01 \mathrm{mg} / \mathrm{L})$ caused mortalities, deformities, or growth inhibition during early development, whereas Imidan ${ }^{\circledR}$, Guthion ${ }^{\circledR}$, and Nova ${ }^{\circledR}$ required higher concentrations to produce survival or growth effects $(5-10 \mathrm{mg} / \mathrm{L})$.

- Ouellet and others (1997) sampled NLFs in farm ponds and nonfarm ponds in the St. Lawrence River Valley of Quebec, Canada, and found a large number of hind limb deformities in frogs from farmland ponds. They blamed pesticides, but no causal link was established.

- Corn and soybean agricultural sites in southwestern Ontario rely heavily on pesticide and nutrient inputs to maximize production (McDaniel and others, 2008). In these agricultural areas, up to 75 percent of male NLFs were found to have some degree of testicular abnormalities (McDaniel and others, 2008). In a few males the severity was such that no differentiated testicular tissue was present, in which case reproductive potential of these individuals was likely impaired. A variety of pesticides, particularly herbicides, and nutrients were detected in the water of these agricultural sites, including atrazine and metolachlor.

- Atrazine disrupts endocrine function and, even at concentrations as low as $0.1 \mathrm{ppb}$, causes retarded gonadal development, hermaphroditism, and oocyte growth in male NLFs (Hayes and others, 2002a; 2002b; 2003). Atrazine contamination is reported to be negatively affecting NLFs from Utah to Iowa (Hayes and others, 2002a; 2002b). Hayes and others (2002b) specifically noted that atrazine contamination has negatively affected NLFs in the Platte River drainage of southeastern Wyoming. Most water sources in the United States, including rain, contain more atrazine than the effective dose determined in laboratory studies (Hayes and others, 2002b).

- The pesticide endosulfan was found to be highly toxic to nine species of amphibians, including NLFs in laboratory experiments (Jones and others, 2009).

- Malathion can threaten NLFs throughout the western United States (Fordham, 1999). Malathion is one of the most commonly used organophosphate insecticides, and is registered for residential and agricultural purposes (US EPA, 1998). Fordham (1999) reported malathion use in the SLV, Colorado, could negatively affect the NLF by altering avoidance behavior, decreasing overall survival, and negatively affect tadpole growth and development.

- Organochloride pesticides (for example, DDE, DDT, and Dieldrin) were banned in the 1970s and 1980s, but are environmentally persistent compounds (Diana and Beasley, 1998). They continue to negatively affect the NLF in the western United States (Smith and Keinath, 2007).

- Pesticides have been shown to compromise the immune system of NLFs (Gilbertson and others, 2003; Christian and others, 2004; Gendron and others, 2003). Christin and others (2004) 
exposed NLFs to a mixture of pesticides known to be present in surface waters of many tributaries of the St. Lawrence River (Quebec, Canada). The mixture included atrazine, metribuzine, endosulfan, lindane, aldicarb, and dieldrin. They found that mixture of pesticides altered the lymphocyte proliferation of NLFs, thereby altering their immune response. They concluded that their altered immune response could be a contributing factor to their global decline by rendering them more susceptible to certain infections (Christin and others, 2004). Gilbertson and others (2003) conducted an injection study and a field study to investigate NLFs immune function response to sublethal doses of DDT, malathion, and dieldrin. They found that antibody response was dramatically suppressed in all of the pesticide-injected groups. The field component revealed significant differences in the immune function between NLF populations in pesticide-exposed and pesticide-free locations, with suppressed immunity in pesticide-exposed sites (Gilbertson and others, 2003). Exposure of NLFs to a pesticide mixture has been shown to affect the infection dynamics of a common parasite of ranid frogs, the lungworm Rhabdias ranae (Gendron and others, 2003). Gendron and others (?) found that migration of the lungworm was significantly accelerated in hosts exposed to the highest concentrations of pesticides, leading to the establishment of twice as many adult worms in the lungs of frogs 21 days post-infection. They concluded that certain components of the frog immune response were significantly suppressed after exposure to the pesticide mixture.

\section{(2) Fertilizers}

Fertilizers have been found to be toxic to amphibians. Rouse and others (1999) found that nitrate levels in many agricultural ecosystems in North America exceeded $1 \mathrm{mg} / \mathrm{L}$ (for example, concentrations that are toxic to amphibians and other aquatic organisms), and concluded that it was highly probable that nitrate concentrations in surface waters in North America are adversely affecting amphibian survival. Hecnar (1995) examined the effects of fertilizers on NLFs (Hecnar, 1995). In this study, NLF tadpoles were exposed to chronic and acute doses of ammonium nitrate fertilizer. In acute doses, tadpoles suffered severe weight loss. In chronic doses, tadpoles not only lost weight, but also died, even at fairly low dosages. The NLF was the most severely affected of the species tested, which included American toads (Bufo americanus), chorus frogs (Pseudacris triseriata), and green frogs (Rana clamitans). Toxic effects of ammonium nitrate occurred in all four species at concentrations that are commonly exceeded in agricultural areas globally. Hecnar (1995) emphasized that the differential mortality of the species tested would likely cause shifts in species composition in free-living communities of amphibians. Runoff from croplands could potentially affect Refuges in the SLV.

Because application of the herbicide atrazine coincides both spatially and temporally with the application of fertilizer, Allran and Karasov (2000) examined the effects of atrazine and nitrate on NLF larvae in the laboratory. They found that atrazine, nitrate, and their interaction had no significant effect on development rate, percent metamorphosis, time to metamorphosis, percent survival, mass at metamorphosis, or hematocrit. They did find that nitrate slowed the growth of larvae.

\section{(3) Mining \& Heavy Metals}

Mining has been practiced in the Rocky Mountain area for at least 150 years (Smith and Keinath, 2007). Although mining has become less important and less destructive in recent years, residue from abandoned mines continues to adversely affect many drainages. Mining causes acidification of water and leads to metals-laden effluent from mines and smelter sites that is discharged into receiving waters. Porter and Hakanson (1976) found that an entire drainage in Colorado was devoid of amphibian life due to runoff from mining residue almost 80 years after mining had ceased. Heavy metals such as 
aluminum, lead, zinc, cadmium, mercury, silver, copper, arsenic, manganese, molybdenum, and antimony have a number of effects on amphibians (Blaustein and others, 2003). These metals can be directly lethal or induce sublethal effects such as slowing growth and development and altering behavior.

Arsenic is frequently released to surface waters from mining, smelting, coal-burning power plants, industries, urban runoff, application of biosolids, fertilizers and pesticides, and atmospheric deposition (ATSDR, 2007; Irving and others, 2008). Arsenic was used in fertilizers in the early 1900s and is a byproduct of the production of sulfuric acid (Smith and Keinath, 2007). Production of arsenic in most nations, including the United States, ceased around the turn of the $20^{\text {th }}$ century, but arsenic can still be a significant pollutant in some parts of the United States (Aurilio and others, 1995). Birge and Just (cited in Linder and Grillitsch, 1973) found that high levels of sodium arsenite were lethal to NLF tadpoles. Chen and others (2009) exposed NLF tadpoles to environmentally relevant concentrations of arsenic and found no significant effect of arsenic exposure on tadpole survival, growth, and metamorphosis. However, they found that tadpoles had decreased swimming speeds in arsenic-treated groups as opposed to control groups.

Lead has the potential to enter waterways via discharge from sewage treatment plants, industries, mining, and highway runoff (Chen and others, 2006). Chen and others (2006) exposed NLFs to sublethal and environmentally relevant concentrations of lead from embryonic stage to metamorphosis. Tadpole growth was significantly slower in the early stages for all doses, and more than 90 percent of the tadpoles in the highest dosage tested in the experiments developed lateral spinal curvature. Spinal deformity was associated with a slower swimming speed. These same authors also studied the effects of copper and cadmium on NLFs and found that both heavy metals affected development, growth, survival, and behavior in larval NLFs at ecologically relevant concentrations (Chen and others, 2007; Gross and others, 2007). Both copper and cadmium occur naturally in soil and is ubiquitous in the environment; however, elevated levels of copper in surface water can occur from mining operations, industrial development, waste water treatments, and agricultural runoff (Chen and others, 2007).

\section{(4) pH/Acidification}

Acidification may contribute to local extinctions of amphibians (Blaustein and others, 2003). For example, Harte and Hoffman (1989) suggested that episodic acidification might have contributed to declines in tiger salamander (Ambystoma tigrinum) populations in the Rocky Mountains, Colorado. The effects of heavy metals on amphibian survival are linked closely to acidification because heavy metals may leach from soil in contact with acidic water (Blaustein and others, 2003). For example, aluminum solubility increases as water $\mathrm{pH}$ drops and aluminum often acts synergistically with $\mathrm{pH}$ to cause embryo mortality in amphibians (Clark and Hall, 1985; Clark and LaZerte, 1985; Freda and McDonald, 1990; Freda and others, 1990).

The effects of acidification of water on frogs has been studied intensively due to the potential for acid rain to cause amphibian declines (Smith and Keinath, 2007). NLF eggs cannot develop normally at pH 5.8 or lower (Schlichter, 1981), and tadpoles were amongst the most sensitive to low pH of all species tested so far (Freda and Taylor, 1992). NLF sperm also showed decreased motility at lower pH, with 50 percent of normal motility at pH 5.5 and maximum motility at pH above 6.5 (Schlichter, 1981). NLFs also show chronic effects of decreased $\mathrm{pH}$, with increasing mortality over time when exposed to low pH waters (Freda and Dunson, 1985; Vatnick and others, 1999). Low pH can also act synergistically with higher levels of UV-B radiation that might result from loss of the ozone layer, resulting in higher mortality in amphibians (Long and others, 1995). Exposure to chronically low levels 
of $\mathrm{pH}$ (5.5) also caused a decrease in white blood cell number and viability in NLFs, which led to systemic bacterial infections, and increased mortality (Simon and others, 2002).

Acidification of water in the Rocky Mountain region can result from acid rain (from air pollution) or mining. Porter and Hakanson (1976) showed that acidification of water locally due to point sources, such as old mines, can cause amphibian mortality. However, Corn and Vertucci (1992) studied the effects of acidic deposition on six species of amphibians, including the NLF, in the mountains of Colorado and Wyoming. They concluded that acid deposition poses little risk regionally to amphibians in the Rocky Mountains. In a follow-up study, Vertucci and Corn (1996) concluded that NLF declines in Colorado were not likely to have been caused by episodic acidification because NLFs generally occupy lakes that have a high acid-neutralizing capability.

\section{(5) Motorized Transportation}

Roads can cause substantial direct mortality as previously mentioned as a landscape-level process. They can also have indirect impacts on NLFs as a consequence of sedimentation and toxic runoff during rain and snowmelt (Smith and Keinath, 2007). Motor oil washes off roads during rain and snowmelt runoff, and when suspended in water can kill some amphibians (Sparling and others, 2000). Crankcase oil in runoff from roads may inhibit amphibian growth (Diana and Beasley, 1998).

\section{(6) Cattle Grazing}

Domestic livestock grazing is one of the most widespread land uses in North America, with more than 70 percent of the western United States reported to be grazed (Maxell, 2000). Livestock, and in particular cattle, produce considerable amounts of waste products that are incorporated in runoff to waterways (Smith, 2003). Directly, livestock grazing has caused mortality to NLFs in Montana (Maxell, 2000). Trampling of amphibians by domestic livestock can result in severe population-level impacts (Bartelt, 1998; Maxell, 2000; Smith, 2003). Trampling of overwintering habitats by domestic livestock may directly or indirectly lead to mortality of vulnerable overwintering NLFs (Maxell, 2000; Smith, 2003). Indirectly, domestic livestock grazing can cause changes in water quality that significantly negatively affect the NLF and its habitat (Maxell, 2000; Smith, 2003). Livestock defecation can increase fecal coliform counts in runoff, in turn increasing phosphorous and nitrogen concentrations and contributing to eutrophication of waters, which can deplete oxygen needed for tadpoles or overwintering adults (Wetzel, 1983; Maxell, 2000). Bacterial pollution caused by defecating livestock can also lead to increases in Planorbid snails, which are carriers of trematode parasites (Ribeiroia spp.), thereby increasing the risk of parasitic infection that can lead to limb malformations and mortality (Johnson and others, 1999; Johnson and Lunde, 2005). Knutson and others (2004) found that ponds used for watering livestock had elevated concentrations of phosphorus, higher turbidity, and a trend toward reduced amphibian reproductive success.

Grazing can adversely alter soils and vegetation and indirectly affect the NLF and its habitat. By trampling banks and vegetation, livestock can eliminate emergent vegetation alongside breeding ponds (Kauffman and Krueger, 1984; Fleischner, 1994; Belskey and others, 1999). Livestock can also reduce or eliminate riparian habitats that are used as dispersal corridors for adults and subadult frogs (Fleischner, 1994; Maxell, 2000; Smith, 2003; Mazerolle and Desrochers, 2005). The elimination of vegetation from grazing can lead to increases in water temperatures (Belskey and others, 1999), which can negatively affect the NLF by making aquatic habitats more hospitable to nonnative bullfrogs (Smith, 2003). 


\section{(7) Sedimentation}

Sediment can run into waterways due to erosion caused by a variety of sources, including roads, domestic livestock grazing, and vegetation removal (Smith, 2003). Sediment can cover NLF eggs in water and probably inhibits gas exchange by eggs. Large fires can also contribute to sedimentation of waterways by producing a lot of wood ash and dead vegetation, thereby increasing the potential for erosion.

\section{(8) Rotenone}

Rotenone is commonly used in fisheries management and can have negative effects on NLFs (Hamilton, 1941; Diana and Beasley, 1998, Patla, 2005). NLF tadpoles cannot survive levels of rotenone typically used to sample fish (Hamilton, 1941).

\section{(9) Polychlorinated biphenyls (PCBs)}

A large amount of literature on PCBs and their effects on amphibians is summarized by Sparling (2000). Although the manufacture and use of PCBs were banned decades ago, these chemicals are still a concern in many areas because of their slow degradation rates and demonstrated ability to undergo food-web biomagnification (Zaranko and others, 1997). These compounds continue to threaten amphibians, including the NLF, throughout the United States (Diana and Beasley, 1998). Phaneuf and others (1995) studied PCB contamination in NLFs in Canada following a fire at a PCB warehouse. They found elevated concentrations in frogs in the area, but were not able to assess mortality in frogs by PCBs released by the fire. In Wisconsin, high concentrations of PCB 126 caused significant mortality on NLF tadpoles in the laboratory (Jofre and others, 2000). However, these authors found no negative effect at concentrations of PCB 126 found in the wild. Karasov and others (2005) studied exposed frog embryos and tadpoles of NLFs along a pollution gradient in the Fox River/Green Bay ecosystem in Wisconsin. They found that hatchability of frog embryo batches and species richness at sites were negatively correlated with contamination levels, but tadpole growth and survival were not. Adult NLFs were found to have low elimination rates for PCBs (Leney and others, 2006). Adults in contaminated areas would likely continue to bioaccumulate PCBs, and therefore could potentially be used as biomonitors for these persistent organic chemicals.

\section{(10) Other Contamination and Limb Malformation}

Organic compounds such as caffeine, acetaminophen, and triclosan in wastewater can have both behavioral and physiological effects on NLF tadpoles (Fraker and Smith, 2004). Both triclosan and caffeine separately, as well as the significant interaction between caffeine and acetaminophen, affected tadpole activity levels, even at the very low concentrations at which the compounds have been detected in the environment. The effects were nonlethal; however, the traits studied in this particular case may have significant impacts on tadpole performance and success. Wastewater effluents are complex mixtures containing a variety of anthropogenic compounds, many of which are known endocrine disruptors. Sowers and others (2009) exposed NLFs to a range of concentrations of municipal wastewater effluent from the egg stage through metamorphosis. At treatments of 50 percent and 100 percent wastewater, individuals took significantly longer to reach metamorphosis than individuals in 0 percent and 10 percent wastewater. Male frogs also had an increased incidence of testicular oocytes in the 50 percent and 100 percent treatments. Study results suggested that municipal wastewater effluent can alter the timing of the metamorphic process and impact male sexual development in NLFs (Sowers and others, 2009). 
Fluoxetine (Prozac) is a selective serotonin reuptake inhibitor (SSRI) commonly found in aquatic ecosystems and organic wastewater. NLF tadpoles exposed to fluoxetine at both high and low concentrations exhibited delays in development and gained less weight than control tadpoles (Foster and others, 2010). Delayed development could put tadpoles at greater risk of desiccation and overcrowding as temporal ponds dry, as well as size-specific predation.

Perfluorooctanesulfonates (PFOS) represent a class of chemicals produced in large amounts over the past two decades for uses such as protective coatings for fabrics, greases and lubricants, adhesives, firefighting foams, and insecticides (Ankley and others, 2004). Monitoring studies found that there were several PFOS extensively distributed in both humans and the environment (Giesy and Kannan, 2001; Ankley and others, 2004). PFOS was lethal to NLFs at concentrations of $10 \mathrm{mg} / \mathrm{L}$ and caused developmental delays in tadpoles at lower concentrations (Ankley and others, 2004).

Limb malformations in amphibians are known from forty states and four Canadian provinces (Northern Prairie Wildlife Research Center, 1997). The most famous recent reports were those from Minnesota, which virtually all concerned metamorphic NLFs (Helgen and others, 1998; Vandenlangenberg and others, 2003). Malformed frogs usually do not survive long because locomotion and basic behavior are seriously compromised by these gross malformations (Merrell, 1969). Currently, three major environmental factors are identified as the causes of malformations: contaminants, parasites, and injuries from predators. The trematode parasite Ribeiroia ondatrae has been responsible for limb malformations and mortality among NLF populations throughout the western United States, including Minnesota (Schotthoefer and others, 2003; Johnson and Lunde, 2005; Sutherland, 2005). This trematode can cause significant levels of mortality among NLF frog tadpoles (Schotthoefer and others, 2003). Parasite-induced limb malformations are reported to be on the rise in the western United States, and has been attributed to extensive human alterations to aquatic systems (Johnson and Lunde, 2005). Researchers suggest multiple causes are likely to blame for worldwide reports of amphibian malformations, and factors leading to malformations at one site may differ from causes at another site (Meteyer and others, 2000.

\section{Intrinsic Threats}

The NLF is intrinsically vulnerable from disturbance factors for a number of reasons. NLFs use small (usually $\leq 5$ ha) ponds in which to breed (Merrell, 1968; 1977, Collins and Wilbur, 1978; Corn and Livo, 1989; Hammerson, 1999). Ponds of this size are often not protected by law (Semlitsch, 2000b) and typically are not addressed in management plans. Smith and Keinath (2007) suggested that it is imperative that management plans take into consideration the distribution of small ponds across the landscape and protection of these ponds to foster healthy populations of NLFs. NLFs also selectively breed in small, fishless ponds, and the introduction of predatory fish to these ponds is a well-known threat to this species. Federal and state agencies frequently introduce such fish throughout the range of the NLF. NLFs also use moist upland habitats surrounding their breeding ponds for summertime foraging. Semlitsch (1998) determined that an upland habitat of up to $164 \mathrm{~m}$ surrounding each breeding pond might be sufficient to protect 95 percent of the adult population of salamanders of various species that use a pond for reproduction in the spring. However, this type of research has not been done for NLFs and it is a critical information need. Amphibians have highly permeable skin, which allows for toxins to be readily absorbed through the skin and incorporated into the body of amphibians, including NLFs. The accumulation of toxins in body tissues of NLFs can have repercussions throughout the food web. Smith and Keinath (2007) suggested that NLFs might serve as a key indicator species in ecosystems in which they occur and that it was possible that NLFs might indicate overall ecosystem health. NLFs are also susceptible to a variety of diseases as mentioned in the previous section. 
Ranavirus has probably always been a threat to NLF populations (Jancovich and others, 1997; Carey and others, 1999, Daszak and other, 1999). Finally, an additional intrinsic threat to NLF populations is their need to move across the landscape for many reasons, including dispersal of metamorphs (Dole, 1971; Merrell, 1977), summer movements associated with feeding (Dole, 1965b; 1967; Merrell, 1977), and migrations to and from overwintering sites (Dole, 1967; Merrell, 1977). The routes followed probably include wet meadows, tall grass, and riparian corridors.

\section{Management}

Semlitsch (2000a) suggested three critical factors to consider in any management plan for aquatic-breeding amphibians: (1) the number or density of the individuals dispersing from individual wetlands (local population dynamics); (2) the diversity of wetlands with regard to hydroperiod (community dynamics); and, (3) the probability of dispersal among adjacent wetlands or the rescue and recolonization of local populations (metapopulation dynamics). Semlitsch (2000a) suggested that it is critical to maintain natural terrestrial habitats peripheral to wetlands to enable amphibians to carry out all life-history functions. Management plans should also consider restoration projects where habitat is degraded or where natural processes have been lost or averted. Small wetland restoration projects were found to be beneficial to NLF populations on Prince Edward Island, Canada (Stevens and others, 2002). Activities near breeding areas that should be avoided include intensive timber harvest, agriculture (including the periodic planting of food plots for game species or mowing), and construction of buildings. If these activities are necessary, buffer zones should be maintained around wetlands or along streams to prevent sedimentation and soil compaction, and removal of coarse woody debris should be minimized (de-Maynadier and Hunter, 1995). Minimizing construction of roads or motorized vehicle traffic near breeding sites was also suggested by Semlitsch (2000a). The use of agricultural and other chemicals near aquatic habitats should be restricted; for example, herbicide use along roads for weed control, salt on roads to eliminate ice, fire retardants, growth retardants on vegetation along roads or under powerlines, and pesticide use to control insects, especially near pools, ditches, streams, and ponds where runoff would find its way into wetlands. Sedimentation in aquatic habitats from permanent roads or temporary logging roads should be minimized to prevent harmful effects on eggs, embryos, and gilled larvae. Wetland management practices that drawdown marshes (also lowering the water table for ephemeral pools) at appropriate times to enhance waterfowl production may decrease the probability of metamorphosis of amphibian species. Flooding marshes (also raising the watertable) for waterfowl may facilitate the colonization of ephemeral pools by predatory fish.

Managers should also consider responses to natural processes such as floods, fires, or succession (Semlitsch, 2000a). Any of these processes can be beneficial or harmful depending on the species, the region, and how the natural disturbance regime interacts with anthropogenic changes to the landscape. Management plans should also eliminate avenues of colonization by predatory fish such as drainage ditches that connect fish-inhabited areas (streams or rivers) with amphibian breeding ponds. Elimination of other invasive species such as exotic fish and bullfrog larvae would serve to promote successful metamorphosis of native species. Plans that maintain natural vegetation buffer zones around ponds (recommended $164 \mathrm{~m}$ from the edge of wetlands; Semlitsch, 1998) and along streams (recommended width 30-100 m but adjusted for stream width, slope, and site use; Rudolph and Dickson, 1990; McComb and others, 1993; deMaynadier and Hunter, 1995) will increase the probability of species persistence.

A selection of citations that provided specific management recommendations for conservation of NLF populations is described below: 
- Hammerson (1999) made several suggestions in relation to management specific to NLFs. He suggested that management for NLFs is probably best accomplished through the creation and protection of habitats that favor leopard frog reproduction but limit or prohibit the successful breeding by bullfrogs and predatory fishes (Hammerson, 1999). Specifically, periodic dewatering or large water-level reductions in late summer after NLFs have metamorphosed might be beneficial. Establishment of semipermanent wetlands among permanent wetlands may allow the persistence of NLFs in areas where bullfrogs and exotic predatory fishes cannot be eliminated without unacceptable damage to other wetland resources. Refuges for NLFs could be established in isolated bodies of water, such as foothill ponds, far from permanent deepwater habitats inhabited by bullfrogs and fishes (Hammerson, 1999).

- In Washington, site occupancy models at a 1-km² scale indicated that occupied areas for NLFs had greater average pond depths, fewer ponds occupied by bullfrogs and carp, and more herbaceous vegetation surrounding the ponds (Germain and Hays, 2009).

- Knutson and others (2005) suggested limiting livestock access to ponds to improve water quality, reducing nitrogen input, and avoiding the introduction of fish.

- $\quad$ There have been several studies on NLFs in managed forest habitats (Bull and Wales, 2001; Blomquist and Hunter, 2009). Blomquist and Hunter (2009) studied NLF habitat selection in a managed forest in Maine. They radiotracked 40 adult NLFs and found that they selected activity centers in the late spring and summer that focused on open-canopy areas with ample moisture and standing water. The frogs also used unharvested forest for longer distance movements. Bull and Wales (2001) reviewed the possible effects of disturbance from various forest management strategies on several species of amphibians, including NLFs, in eastern Oregon and Washington. The management strategies considered included thinning of vegetation, prescribed burns, road removal, and spraying with pesticides and biological microbial agents. They concluded that there should be no negative effects on NLFs from management strategies associated with forest health unless spraying with pesticides decreased the abundance of their potential prey, there was road building associated with thinning, or water level or quality was compromised during the embryonic and larval periods (Bull and Wales, 2001).

- McLeod and Gates (1998) concluded that in general, forest cutting and burning could locally decrease herpetofaunal diversity, but diversity on a much larger scale could potentially increase. Prescribed burning on experimental forest plots has been shown to increase diversity and abundance of amphibians and reptiles over control plots (Mushinsky, 1985). However, there is no consistent response of amphibians to prescribed fire; it appears to vary by ecoregion, habitat, and species. Some studies suggested burning negatively affects amphibians (for example, Jones and others, 2000; Pilliod and others, 2003; Schurbon and Fauth, 2003), whereas others found either positive effects, failed to detect significant effects, or found mixed effects whereby some species benefit and others decline (for example, Means and Campbell, 1982; Greenberg, 1994; Ford and others, 1999; Moseley and others, 2003). In a review of the effects of prescribed fire on herpetofauna, Russell and others (1999) found that prescribed fire can be an important tool to maintain aquatic habitats of some herpetofauna. In the current literature survey, however, no studies were found that specifically addressed the effects of prescribed fire on NLFs, and therefore this is definitely a research gap.

- Several studies have suggested that connectivity among breeding, summer, and overwintering habitat for NLFs may be equally as important as the simple abundance of these habitats (Pope and others, 2000; Gibbs and others, 2005; Eigenbrod and others, 2008). Mazerolle and Desrochers (2005) studied the landscape movements of NLFs and found that when presented 
with a choice, 72 percent of the individuals avoided anthropically disturbed surfaces devoid of cover, such as mined peatlands and agricultural fields. The authors concluded that these disturbed areas disrupted the ability of frogs to reach new habitat patches.

- One of the most important management activities could be simply initiating surveys for NLFs (McAllister and others, 1999). It is important for the conservation of NLFs in the SLV to find additional occupied habitat, if it occurs. McAllister and others (1999) suggested that once ponds occupied by NLFs are found, they should be mapped, monitored, and evaluated. Annual or biennial egg mass counts could also be performed. Transects could be established for the late summer or early fall to determine numbers, sex, and ages of leopard frogs. Dieni (2009) also strongly recommended that an inventory of amphibians be conducted on the wet meadows of Baca NWR, with an emphasis on anurans, such as the NLF.

- Smith and Keinath (2007) suggested that the following conservation and management factors should be considered when trying to conserve NLFs in the Rocky Mountain region:

- Protection of known and potential breeding sites

Semlitch and Bodie (1998) and Semlitch (2000b) noted that breeding ponds that produced the highest density and biodiversity of amphibians are not protected by current Federal law. While streams, springs, and large lakes are protected, NLFs need smaller (less than 5 ha) seasonal and semi-permanent ponds (Semlitch and Bodie, 1998; Semlitch, 2000b).

Upland areas surrounding these ponds are used throughout the summer as foraging habitat and must also be protected (Semlitsch, 1998; 2000a). Dole (1965a; 1965b) showed that NLFs typically used a home range of about 68 to $503 \mathrm{~m}^{2}$, but Dole's work does not provide specific guidance for how much upland core area should be protected to conserve an entire population because some of that population will have home ranges farther from the breeding pond than other members (Smith and Keinath, 2007). Adult NLFs typically avoid upland areas that have grass more than one meter tall, wooded areas, open areas lacking vegetation, and heavily grazed or mowed areas (Merrell, 1977; Mazerolle and Desrochers, 2005).

The pattern of spacing of suitable breeding sites across the landscape and upland movements made by NLFs are probably both important in colonization of new ponds or recolonization of ponds in which breeding populations have gone extinct, thus maintaining a healthy metapopulation of the species in any area. Frog movements and pond spacing are two of the most important factors to consider in management of NLFs (Smith, 2003).

- Control of introduced predaceous fish

Introduced nonnative predaceous fish have been clearly implicated in the decline of some frogs (Bovbjerg, 1965; Hecnar and M’Closkey, 1997b), and ongoing fisheries management by various agencies maintain populations of these fish throughout the Rocky Mountain region. If fish are found in ponds with NLFs, they might be safely removed by electroshocking or rotenone, but only when NLFs are not in the pond (Smith and Keinath, 2007).

- Protection of overwintering sites

It is important to identify and protect overwintering sites for NLFs since overwintering mortality of ranid frogs can be high at times (Bradford, 1983). NLFs use lakes, larger ponds, and streams in which to overwinter (Merrell, 1977; Cunjak, 1986), but identification of specific sites requires underwater work during the winter, and no 
work has been done in the Rocky Mountain region to my knowledge. More research is needed on winter ecology for NLFs.

- Control of introduced infectious diseases

Modes of infectious disease transmission are now well known for NLFs (Smith and Keinath, 2007). Carey and others (1999) noted that introduced exotics might spread disease, and tiger salamanders are known to harbor iridoviruses (Daszak and others, 1999). Presumably, diseases can travel on any animal agent, including humans, from pond to pond.

- Water quality

Water quality has major effects on amphibians, as demonstrated previously. Ponds, especially those known to have breeding and overwintering populations of frogs, should be monitored for the quality of their water, particularly those close to sources of pollutants, those where herbicides and pesticides may be used to control exotic plants and other noxious organisms, those near construction sites or logging activities, those near oil and gas development, and those near roadways and ponds near recreation sites (Smith and Keinath, 2007).

- Protection of migratory or dispersal pathways

Dole (1965b; 1967; 1971) and Merrell (1977) found that NLFs use many routes and habitats for migration and dispersal, including wet meadows, tall grass, and riparian corridors. Habitat destruction and road construction interrupt these pathways, and it is likely that grazing and logging do so as well (Smith and Keinath, 2007). Smith and Keinath (2007) suggested that these movement corridors be afforded protection, but no detailed studies were found that examine the management of such areas. It would be necessary to understand the landscape (for example, where ponds are placed, where riparian corridors are located and how these relate to ponds, and where wet meadows and tall grass are located) to manage migratory pathways (Smith and Keinath, 2007). Also needed is more research on how frogs move among suitable breeding ponds.

- Road-related mortality

Limiting and controlling the amount of road-related mortality was suggested as an important management consideration by Smith and Keinath (2007). As already noted, in addition to the fragmentation of the landscape, roads can result in direct mortality to NLFs.

Other factors can have unexpected effects on NLFs, such as immobility response due to generalized noise (Nash and others, 1970) and temporary blinding by bright lights (Buchanan, 1993). Sometimes controlling for these factors could be impractical, but they should be considered in any land management and work planning (Smith and Keinath, 2007). For instance, the effects of bright lights should be considered where important breeding ponds are located near lighted facilities such as offices, work areas, and campgrounds.

\section{Research Priorities}

The following research priorities were found in the literature review:

- Smith and Keinath (2007) describe the following broad categories of information needs for NLFs in Region 2 of the USFS (Rocky Mountain Region): (1) Survey and monitoring; (2) Mapping of habitat; (3) Characterization of habitat; (4) Characterizing 
overwintering habitat using radiotelemetry; (5) Studies of movements both within the breeding season and during migration; (6) Disease, pollution, and limb malformations; (7) Effects of introduced predaceous fish; (8) Effects of cattle grazing; (9) Effects of forest management practices, specifically timber removal; (10) Effects of roadways; (11) Genetic studies; and, (12) Effects of prescribed fire and fire suppression.

- The NLF Recovery Plan for Alberta (Alberta Northern Leopard Frog Recovery Team, 2010) suggested that research to facilitate the conservation and recovery of the species should focus on monitoring of populations and habitat, and evaluating the effectiveness of recovery initiatives. Research should also continue on developing increasingly effective protocols for reintroduction and establishment of NLF populations. The Recovery Team further suggest that "genetic information collected from Alberta populations and populations from other jurisdictions should be used to help guide the reintroduction program (for example, information on genetic diversity, local adaptations).” Research tools such as geographic information systems (GIS) technology should be used to identify potential sites for translocation of NLFs and to identify previously unknown sites that may support the species. Finally, all recovery activities will require the surveillance for, and possible study of, diseases that may affect populations and reintroduction efforts (Alberta Northern Leopard Frog Recovery Plan, 2010).

\section{Bibliography}

Adams, M.J., Richter, K.O., and Leonard, W.P., 1997, Surveying and monitoring amphibians using aquatic funnel traps, in Olson, D.H., Leonard, W.P., and Bury, R.B., eds., Sampling amphibians in lentic habitats: methods and approaches for the Pacific Northwest, Northwest Fauna, No. 4., p. 47-54.

Agency for Toxic Substances and Disease Registry (ATSDR), 2007, Toxicological profile for arsenic: Public Health Services, U.S. Department of Health and Human Services, Atlanta, Georgia.

Alberta Northern Leopard Frog Recovery Team, 2010, Alberta Northern Leopard Frog Recovery Plan, 2005-2010: Alberta Sustainable Resource Development, Fish and Wildlife Division, Alberta Species at Risk Recovery Plan No. 7, Edmonton, Alberta, 26 pp.

Alford, R.A., 1999, Resource use, competition, and predation, in McDiarmid, and Altig, R., eds., Tadpoles: the biology of anuran larvae, The University of Chicago Press, Chicago, Illinois, p. 240278.

Allran, J.W., and Karasov, W.H., 2000, Effects of atrazine and nitrate on northern leopard frog (Rana pipiens) larvae exposed in the laboratory from posthatch through metamorphosis: Environmental Toxicology and Chemistry, v. 19, p. 2850-2855.

Anderson, A.M., Haukos, D.A., Anderson, and Anderson, J.T., 1999, Habitat use by anurans emerging and breeding in playa wetlands: Wildlife Society Bulletin, v. 27, p. 759-769.

Ankley, G.T., Tietge, J.E., DeFoe, D.L., Jensen, K.M., Holcombe, G.W., Durham, E.J., and Diamond, S.A., 1998, Effects of ultraviolet light and methoprene on survival and development of Rana pipiens: Environmental Toxicology and Chemistry, v. 17, p. 2530-2542.

Ankley, G.T., Tietge, J.E., Holcombe, G.W., DeFoe, D.L., Diamond, S.A., Jensen, K.M., and Degitz, S.J., 2000, Effects of laboratory ultraviolet radiation and natural sunlight on survival and development of Rana pipiens: Canadian Journal of Zoology, v. 78, p. 1092-1100.

Ankley, G.T., Kuehl, D.W., Kahl, M.D., Jensen, K.M., Butterworth, B.C., and Nichols, J.W., 2004, Partial life-cycle toxicity and bioconcentration modeling of perfluorooctanesulfonate in the northern leopard frog (Rana pipiens): Environmental Toxicology and Chemistry, v. 23, p. 2745-2755. 
Aronson, L.R., and Noble, G.K., 1945, The sexual behavior of Anura. 2. Neural mechanisms controlling mating in the male leopard frog, Rana pipiens: Bulletin of the American Museum of Natural History, v. 86, p. 83-140.

Ashley, E.P., and Robinson, J.T., 1996, Road mortality of amphibians, reptiles, and other wildlife on the Long Point Causeway, Lake Erie, Ontario: Canadian Field-Naturalist, v. 110, p. 403-412.

Aurilio, A.C., Durant, J.L., Hemond, H.F., and Knox, M.L., 1995, Sources and distribution of arsenic in the Aberjona watershed, eastern Massachusetts: Water, Air, and Soil Pollution, v. 81, p. 265-282.

Baber, M.J., and Babbitt, K.J., 2003, The relative impacts of native and introduced predatory fish on a temporary wetland tadpole assemblage: Oecologia, v. 136, p. 289-295.

Bagdonas, K.R., 1968, Variation in Rocky Mountain wood frogs: Unpublished M.A. Thesis, Colorado State University, Fort Collins, Colorado.

Baker, J.M.R., and Halliday, T.R., 1999, Amphibian colonization of new ponds in an agricultural landscape: Herpetological Journal, v. 9, p. 55-63.

Baker, M.R., 1987, Synopsis of the Nematoda parasitic in amphibians and reptiles: Memorial University of Newfoundland, Miscellaneous Publications in Biology, v. 11, p. 1-325.

Ballinger, R.E., Lynch, J.D., and Cole, P.H., 1979, Distribution and natural history of amphibians and reptiles in western Nebraska with ecological notes on the herpetiles [sic] of Arapaho Prairie: Prairie Naturalist, v. 11, p. 65-74.

Bartelt, P.E., 1998, Natural history notes: Bufo boreas mortality: Herpetological Review, v. 29, p. 96.

Baxter, G.T., 1952, Notes on growth and reproductive cycle of the leopard frog, Rana pipiens Schreber, in southern Wyoming: Journal of the Colorado-Wyoming Academy of Science, v. 4, p. 91.

Baxter, G.T., and Stone, M.D., 1985, Amphibians and reptiles of Wyoming, $2^{\text {nd }}$ edition: Wyoming Game and Fish Department, 137 pp.

Beauregard, N., and Leclair, R., Jr., 1988, Multivariate analysis of the summer habitat structure of Rana pipiens Schreber, in Lac Saint Pierre (Quebec, Canada), in Szaro, R.C., Severson, K.E., and Patton, D.R., eds., Management of Amphibians, Reptiles and Small Mammals in North America, USDA Forest Service General Technical Report RM-166, p. 129-143. 458 pp.

Beche, L.A., Stephens, S.L., and Resh, V.H., 2005, Effects of prescribed fire on a Sierra Nevada (California, USA) stream and its riparian zone: Forest Ecology and Management, v. 218, p. 37-59.

Belskey, A.J., Matzke, A., and Uselman, S., 1999, Survey of livestock influences on stream and riparian ecosystems in the western United States: Journal of Soil and Water Conservation, v. 54, p. 419-431.

Berger, L., Speare, R., Daszak, P., Green, D.E., Cunningham, A.A., Goggin, C.L., Slocombe, R., Ragan, M.A., Hyatt, A.D., McDonald, K.R., Hines, H.B., Lips, K.R., Marantelli, G., and Parkes, H., 1998, Chytridiomycosis causes amphibian mortality associated with population declines in the rainforests of Australia and Central America: Proceedings of the National Academy of Science, v. 95, p. 9031-9036.

Berger, L., Speare, R., and Hyatt, A.D., 1999, Chytrid fungi and amphibian declines: overview, implications and future directions: Pp. 23-33 in Campbell, A., ed., Declines and Disappearances of Australian Frogs: Environment Australia, Canberra, 236 pp.

Berrill, M., Bertram, S., Brigham, D., and Campbell, V., 1992, A comparison of three methods of monitoring frog populations: Pp. 87-93 in Bishop, C.A., and Pettit, K.E., eds., Declines in Canadian Amphibian Populations: Designing a National Monitoring Strategy, Occasional Paper Number 76, Canadian Wildlife service, Ottawa, Ontario, Canada, 120 pp.

Berrill, M., Bertram, S., Wilson, A., Louis, S., Brigham, D., and Stromberg, C., 1993, Lethal and sublethal impacts of pyrethroid insecticides on amphibian embryos and tadpoles: Environmental Toxicology and Chemistry, v. 12, p. 525-539. 
Berrill, M., Bertram, S., McGillivray, L., Kolohon, M., and Pauli, B., 1994, Effects of low concentrations of forest-use pesticides on frog embryos and tadpoles: Environmental Toxicology and Chemistry, v. 13, p. 657-664.

Berrill, M., Bertram, S., and Pauli, B., 1997, Effects of pesticides on amphibian embryos and larvae: Pp. 233-245 in Green, D.M., ed., Amphibians in Decline: Canadian Studies of a Global Problem, Herpetological Conservation, Number One, Society for the Study of Amphibians and Reptiles, St. Louis, Missouri, 338 pp.

Bishop, C.A., 1992, The effects of pesticides on amphibians and the implications for determining the causes of declines in amphibian populations: in Bishop, C.A., and Pettit, K.E., eds., Declines in Canadian Amphibian Populations: Designing a National Monitoring Strategy, Ottawa, Ontario, Canadian Wildlife Service, Occasional Paper Number 76.

Bishop, C.A., and Pettit, K.E., eds., 1992, Declines in Canadian Amphibian Populations: Designing a National Monitoring Strategy, Ottawa, Ontario, Canadian Wildlife Service, Occasional Paper Number 76.

Bishop, C.A., Mahony, N.A., Struger, J., Ng, P., and Pettit, K.E., 1999, Anuran development, density and diversity in relation to agricultural activity in the Holland River watershed, Ontario, Canada (1990-1992): Environmental Monitoring and Assessment, v. 57, p. 21-43.

Bishop, C.A., Struger, J., Shirose, L.J., Dunn, L., and Campbell, G.D., 2000, Contamination and wildlife communities in stormwater detention ponds in Guelph and the Greater Toronto Area, Ontario, 1997 and 1998. Part II - Contamination and biological effects of contamination: Water Quality Research Journal of Canada, v. 35, p. 437-474.

Blaustein, A.R., Romansic, J.M., Kiesecker, J.M., and Hatch, A.C., 2003, Ultraviolet radiation, toxic chemicals and amphibian population declines: Diversity and Distributions, v. 9, p. 123-140.

Blaustein, A.R., Romansic, J.M., Scheessele, E.A., Han, B.A., Pessier, A.P., and Longcore, J.E., 2005, Interspecific variation in susceptibility of frog tadpoles to the pathogenic fungus Batrachochytrium dendrobatidis: Conservation Biology, v. 19, p. 1460-1468.

Blomquist, S.M., and Hunter, M.L., Jr., 2009, A multi-scale assessment of habitat selection and movement patterns by northern leopard frogs (Lithobates [Rana] pipiens) in a managed forest: Herpetological Conservation and Biology, v. 4, p. 142-160.

Bonin, J., Ouellet, M., Rodrigue, J., DesGranges, J.L., Gagne, F., Sharbel, T.F., and Lowcock, L.A., 1997, Measuring the health of frogs in agricultural habitats subjected to pesticides: Pp. 246-258 in Green, D.M., ed., Amphibians in Decline: Canadian Studies of a Global Problem, Herpetological Conservation, Number One, Society for the Study of Amphibians and Reptiles, St. Louis, Missouri, 338 pp.

Bovbjerg, R.V., 1965, Experimental studies on the dispersal of the frog, Rana pipiens: Proceedings of the Iowa Academy of Science, v. 72, p. 412-418.

Bovbjerg, R.V., and Bovbjerg, A.M., 1964, Summer emigrations of the frog Rana pipiens in northwestern Iowa: Proceedings of the Iowa Academy of Science, v. 71, p. 511-518.

Boyer, R., and Grue, C., 1995, The need for water quality criteria for frogs: Environmental Health Perspectives, v. 103, p. 352-357.

Bradford, D.F., 1989, Allotopic distribution of native frogs and introduced fishes in high Sierra Nevada lakes of California: implications of the negative effect of fish introductions: Copeia, v. 1989, p. 775778.

Bradford, F.G., 1983, Winterkill, oxygen relations, and energy metabolism of a submerged dormant amphibian, Rana muscosa: Ecology, v. 64, p. 1171-1183. 
Bridges, C., Little, E., Gardiner, D., Petty, J., and Huckins, J., 2004, Assessing the toxicitiy and teratogenicity of pond water in north-central Minnesota to amphibians: Environmental Science and Pollution Research, v. 11, p. 233-239.

Brodkin, M.A., Simon, M.P., DeSantis, A.M., and Boyer, K.J., 1992, Response of Rana pipiens to graded doses of the bacterium Pseudomnas aeruginosa: Journal of Herpetology, v. 26, p. 490-495.

Buchanan, B., 1993, Effects of enhanced lighting on the behavior of nocturnal frogs: Animal Behaviour, v. 45, p. 893-899.

Buckhouse, J.C., and Gifford, G.F., 1976, Water quality implications of cattle grazing on a semi-arid watershed in southeastern Utah: Journal of Range Management, v. 29, p. 109-113.

Bull, E.L., and Hayes, M.P., 2000, Livestock effects on reproduction of the Columbia spotted frog: Journal of Range Management, v. 53, p. 291-294.

Bull, E.L., and Wales, B.C., 2001, Effects of disturbance on amphibians of conservation concern in eastern Oregon and Washington: Northwest Science, v. 75, p. 174-179.

Carey, C., Cohen, N., and Rollins-Smith, L., 1999, Amphibian declines: an immunological perspective: Developmental and Comparative Immunology, v. 23, p. 459-472.

Carr, L.W., and Fahrig, L., 2001, Effect of road traffic on two amphibian species of differing vagility: Conservation Biology, v. 15, p. 1071-1078.

Center for Native Ecosystems, Biodiversity Conservation Alliance, Defenders of Black Hills, Forest Guardians, Center for Biological Diversity, The Ark Initiative, Native Ecosystems Council, Rocky Mountain Clean Air Action, and Nicholes, J., 2006, Petition before the Secretary of Interior - petition to list the western United States population of northern leopard frog (Rana pipiens) as threatened:

Accessed online at http://nativeecosystems.org/wp-content/uploads/2006-612_final_leopard_frog_petition11.pdf. Accessed on 15 May 2011.

Chen, T.H., Gross, J.A., and Karasov, W.H., 2006, Sublethal effects of lead on northern leopard frog (Rana pipiens) tadpoles: Environmental Toxicology and Chemistry, v. 25, p. 1383-1389.

Chen, T.H., Gross, J.A., and Karasov, W.H., 2007, Adverse effects of chronic copper exposure in larval northern leopard frogs (Rana pipiens): Environmental Toxicology and Chemistry, v. 26, p. 14701475.

Chen, T.H., Gross, J.A., and Karasov, W.H., 2009, Chronic exposure to pentavalent arsenic of larval leopard frogs (Rana pipiens): bioaccumulation and reduced swimming performance: Ecotoxicology, v. 18, p. 587-593.

Christin, M.S., Menard, L., Gendron, A.D., Ruby, S., Cyr, D., Marcogliese, D.J., Rollins-Smith, L., and Fournier, M., 2004, Effects of agricultural pesticides on the immune system of Xenopus laevis and Rana pipiens: Aquatic Toxicology, v. 67, p. 33-43.

Churchill, T.A., and Storey, K.B., 1995, Metabolic effects of dehydration on an aquatic frog, Rana pipiens: Journal of Experimental Biology, v. 198, p. 147-154.

Clark, K.L., and Hall, R.J., 1985, Effects of elevated hydrogen ion and aluminum concentration on the survival of amphibian embryos and larvae: Canadian Journal of Zoology, v. 63, p. 116-123.

Clark, K.L, and LaZerte, B., 1985, A laboratory study on the effects of aluminum and pH on amphibians eggs and tadpoles: Canadian Journal of Fisheries and Aquatic Sciences, v. 42, p. 1544-1551.

Clarkson, R.W., and Rorabaugh, J.C., 1989, Status of leopard frogs (Rana pipiens complex: Ranidae) in Arizona and southeastern California: Southwestern Naturalist, v. 34, p. 531-538.

Cockerell, T.D.A., 1910, Reptiles and amphibians of the University of Colorado expedition of 1909 : University of Colorado Studies, v. 7, p. 130-131.

Collier, A., Keiper, J.B., and Orr, L.P., 1998, The invertebrate prey of the northern leopard frog, Rana pipiens, in a northeastern Ohio population: Ohio Journal of Science, v. 98, p. 39-41. 
Conant, R., and Collins, J.T., 1998, A field guide to reptiles and amphibians: eastern and central North America, $4^{\text {th }}$ edition: Houghton Mifflin Harcourt, Boston, Massachusetts, 640 pp.

Cooke, A.S., 1981, Tadpoles as indicators of harmful levels of pollution in the field: Environmental Pollution Series A, v. 25, p. 123-133.

Corn, P.S., 1981, Field evidence for a relationship between color and development rate in the northern leopard frog (Rana pipiens): Herpetologica, v. 37, p. 155-160.

Corn, P.S., and Fogleman, J.C., 1984, Extinction of montane populations of the northern leopard frog (Rana pipiens) in Colorado: Journal of Herpetology, v. 18, p. 147-152.

Corn, P.S., and Livo, L.J., 1989, Leopard frog and wood frog reproduction in Colorado and Wyoming: Northwestern Naturalist, v. 70, p. 1-9.

Corn, P.S., and Vertucci, F.A., 1992, Descriptive risk assessment of the effects of acidic deposition on Rocky Mountain amphibians: Journal of Herpetology, v. 26, p. 361-369.

Corn, P.S., Stolzenburg, W., and Bury, R.B., 1989, Acid precipitation studies in Colorado and Wyoming: interim report of surveys of montane amphibians and water chemistry: U.S. Fish and Wildlife Service Biological Report, v. 80 (40.26), 56 pp.

Cousineau, M., and Rogers, K., 1991, Observations on sympatric Rana pipiens, R. blairi, and their hybrids in eastern Colorado: Journal of Herpetology, v. 25, p. 114-116.

Croteau, M.C., Martyniuk, C.J., Trudeau, V.L., and Lean, D.R.S., 2008, Chronic exposure of Rana pipiens tadpoles to UVB radiation and the estrogenic chemical 4-tert-octylphenol: Journal of Toxicology and Environmental Health-Part A-Current Issues, v. 71, p. 134-144.

Crump, D., Berrill, M., Coulson, D., Lean, D., McGillivray, L., and Smith, A., 1999, Sensitivity of amphibian embryos, tadpoles, and larvae to enhanced UV-B radiation in natural pond conditions: Canadian Journal of Zoology, v. 77, p. 1956-1966.

Cunjak, R.A., 1986, Winter habitat of northern leopard frogs, Rana pipiens, in a southern Ontario stream: Canadian Journal of Zoology, v. 64, p. 255-257.

Cushman, S.A., 2006, Effects of habitat loss and fragmentation on amphibians: A review and prospectus: Biological Conservation, v. 128, p. 231-240.

Daszak, P., Berger, L., Cunningham, A.A., Hyatt, A.D., Green, D.E., and Speare, R., 1999, Emerging infectious diseases and amphibian population declines: Emerging Infectious Diseases, v. 5, p. 735748.

Daszak, P. Strieby, A., Cunningham, A.A., Longcore, J.E., Brown, C.C. and Porter, D., 2004, Experimental evidence that the bullfrog (Rana catesbeiana) is a potential carrier of chytridiomycosis, an emerging fungal disease in amphibians: Herpetological Journal, v. 14, p. 201-207.

DeBenedictis, P.A., 1974, Interspecific competition between tadpoles of Rana pipiens and Rana sylvatica: An experimental field study: Ecological Monographs, v. 44, p. 129-151.

DeGarady, C.J., and Halbrook, R.S., 2006, Using anurans as bioindicators of PCB contaminated streams: Journal of Herpetology, v. 40, p.127-130.

deMaynadier, P.G., and Hunter, M.L., Jr., 1995, The relationship between forest management and amphibian ecology: a review of the North American literature: Environmental Reviews, v. 3, p. 230261.

deMaynadier, P.G., and Hunter, M.L., Jr., 1998, Effects of silvicultural edges on the distribution and abundance of amphibians in Maine: Conservation Biology, v. 12, p. 340-352.

Detenbeck, N.E., Hermanutz, R., Allen, K., and Swift, M.C., 1996, Fate and effects of the herbicide atrazine in flow-through wetland mesocosms: Environmental Toxicology and Chemistry, v. 15, p. 937-946. 
Dial, N.A., and Dial, C.A.B., 1987, Lethal effects of diquat and paraquat on developing frog embryos and 15-day-old tadpoles, Rana pipiens: Bulletin of Environmental Contamination and Toxicology, v. 38, p. 1006-1011.

Diana, S.G., and Beasley, V.R., 1998, Amphibian toxicology: Pp. 266-277 in Lannoo, M.J., ed., Status and Conservation of Midwestern Amphibians, University of Iowa Press, Iowa City, Iowa, 507 pp.

Distel, C.A., and Boone, M.D., 2010, Effects of aquatic exposure to the insecticide carbaryl are speciesspecific across life stages and mediated by heterospecific competitors in anurans: Functional Ecology, v. 24, p.1342-1352.

Distel, C.A., and Boone, M.D., 2011, Pesticide has asymmetric effects on two tadpole species across density gradient: Environmental Toxicology and Chemistry, v, 30, p. 650-658.

Dodd, C.K., Jr., and Seigel, R.A., 1991, Relocation, repatriation, and translocation of amphibians and reptiles: are they conservation strategies that work?: Herpetologica, v. 47, p. 336-350.

Dole, J.W., 1965a, Spatial relations in natural populations of the leopard frog, Rana pipiens Schreber, in northern Michigan: American Midland Naturalist, v. 74, p. 464-478.

Dole, J.W., 1965b, Summer movement of adult leopard frogs, Rana pipiens (Schreger), in northern Michigan: Ecology, v. 46, p. 236-255.

Dole, J.W., 1967, Spring movements of leopard frogs, Rana pipiens Schreber, in northern Michigan: American Midland Naturalist, v. 78, p. 167-181.

Dole, J.W., 1968, Homing in leopard frogs, Rana pipiens: Ecology, v. 49, p. 386-399.

Dole, J.W., 1971, Dispersal of recently metamorphosed leopard frogs, Rana pipiens: Copeia, v. 1971, p. 221-228.

Dole, J.W., 1972, The role of olfaction and audition in the orientation of leopard frogs, Rana pipiens: Herpetologica, v. 28, p. 258-260.

Dorchin, A., and Shanas, U., 2010, Assessment of pollution in road runoff using a Bufo viridis biological assay: Environmental Pollution, v. 158, p. 3626-3633.

Drake, C.J., 1914, The food of Rana pipiens: The Ohio Naturalist, v. 14, p. 257-269.

Dubois, R.B., and Stoll, F.M., 1995, Downstream movement of leopard frogs in a Lake Superior tributary exemplifies the concept of a lotic macrodrift: Journal of Freshwater Ecology, v. 10, p. 135139.

Duellman, D.G., and Trueb, L., 1986, Biology of amphibians: McGraw-Hill, Inc., New York, New York, 670 pp.

Dunlap, D.G., and Kruse, K.C., 1976, Frogs of the Rana pipiens complex in the northern and central plains states: Southwestern Naturalist, v. 20, p. 559-571.

Dunlap, D.G., and Kruse, K.C., 1981, Geographic variation of protein and call in Rana pipiens from northcentral United States: Copeia, v. 1981, p. 876-879.

Echaubard, P., Little, K., Pauli, B., and Lesbarreres, D., 2010, Context-dependent effects of ranaviral infection on northern leopard frog life history traits: PLoS ONE, v. 5, e13723.

Ehrlich, D., 1979, Predation by bullfrog tadpoles (Rana catesbeiana) on eggs and newly hatched larvae of the plains leopard frog (Rana blairi): Bulletin of the Maryland Herpetological Society, v. 15, p. 2526.

Eigenbrod, F., Hecnar, S.J., and Fahrig, L., 2008, The relative effects of road traffic and forest cover on anuran populations: Biological Conservation, v. 141, p. 35-46.

Emery, A.R., Berst, A.H., and Kodaira, K., 1972, Under-ice observations of wintering sites of leopard frogs: Copeia, v. 1972, p. 123-126. 
Euliss, N., and Mushet, D., 2004, Impacts of water development on aquatic invertebrates, amphibians, and plants in wetlands of a semi-arid landscape: Aquatic Ecosystem Health and Management, v. 7, p. 73-84.

Feder, M.E., and Moran, C.M., 1985, Effect of water depth on costs of aerial respiration and its alternatives in tadpoles of Rana pipiens: Canadian Journal of Zoology, v. 63, p. 643-648.

Fleischner, T.L., 1994, Ecological costs of livestock grazing in western North America: Conservation Biology, v. 8, p. 629-644.

Force, E.R., 1933, The age of the attainment of sexual maturity of the leopard frog Rana pipiens (Schreber) in northern Michigan: Copeia, v. 1933, p. 128-131.

Ford, W.M., Menzel, M.A., McGill, D.W., Laerm, J., and McCray, T.S., 1999, Effects of community restoration fire on small mammals and herpetofauna in the southern Appalachians: Forest Ecology and Management, v. 114, p. 233-243.

Fordham, C.L., 1999, Toxicology of malathion in bullfrogs and leopard frogs: Unpublished PhD Dissertation, Colorado State University, Fort Collins, Colorado, 149 pp.

Foster, H.R., Burton, G.A., Basu, N., and Werner, E.E., 2010, Chronic exposure to fluoxetine (Prozac) causes developmental delays in Rana pipiens larvae: Environmental Toxicology and Chemistry, v. 29, p. 2845-2850.

Fowler, R.L., 1935, Some amphibians and reptiles of the district around High River, Alberta, 1933 : Canadian Field-Naturalist, v. 48, p. 139-140.

Fraker, S.L., and Smith, G.R., 2004, Direct and interactive effects of ecologically relevant concentrations of organic wastewater contaminants on Rana pipiens tadpoles: Environmental Toxicology, v. 19, p. 250-256.

Freda, J., and Dunson, W.A., 1985, Field and laboratory studies of ion balance and growth rates of ranid tadpoles chronically exposed to low pH: Copiea, v. 1985, p. 415-423.

Freda, J., and McDonald, D., 1990, Effects of aluminum on the leopard frog Rana pipiens: life stage comparisons and aluminum uptake: Canadian Journal of Fisheries and Aquatic Sciences, v. 47, p. 210-216.

Freda, J., and Taylor, D.H., 1992, Behavioral response of amphibian larvae to acidic water: Journal of Herpetology, v. 26, p. 429-433.

Freda, J., Cavdek, V., and McDonald, D., 1990, Role or organic complexation in the toxicity of aluminum to Rana pipiens embryos and Bufo americanus tadpoles: Canadian Journal of Fisheries and Aquatic Sciences, v. 47, p. 217-224.

Fried, B., Pane, P.L., and Reddy, A., 1997, Experimental infection of Rana pipiens tadpoles with Echinostomatrivolvis cercariae: Parasitology Research, v. 83, p. 666-669.

Frost, D.R, Grant, T., Faivovich, J., Bain, R.H., Haas, A., Haddad, C.F.B., deSa, R.O., Channing, A., Wilkinson, M., Donnellan, S.C., Raxworthy, C.J., Campbell, J.A., Blotto, B.L., Moler, P., Drewes, R.C., Nussbaum, R.A., Lynch, J.D., Green, D.M., Wheeler, W.C., 2006, The amphibian tree of life: Bulletin of the American Museum of Natural History, v. 297, p. 1-370.

Gehlbach, F.R., 1965, Herpetology of the Zuni Mountains region of northwestern New Mexico: Proceedings of the U.S. National Museum, v. 116, p. 243-332.

Gendron, A.D., Marcogliese, D.J., Barbeau, S., Christin, M.S., Brousseau, P., Ruby, S., Cyr, D., and Fournier, M., 2003, Exposure of leopard frogs to a pesticide mixture affects life history characteristics of the lungworm Rhabdias ranae: Oecologia, v. 135, p. 469-476.

Germaine, S.S., and Hays, D.W., 2009, Distribution and postbreeding environmental relationships of northern leopard frogs (Rana [Lithobates] pipiens) in Washington: Western North American Naturalist, v. 69, p. 537-547. 
Gibbs, E.G., Nace, W., and Emmons, M.B., 1971, The live frog almost dead: Bioscience, v. 21, p. 10271034.

Gibbs, J.P., Whiteleather, K.K., and Schueler, F.W., 2005, Changes in frog and toad populations over 30 years in New York State: Ecological Applications, v. 15, p. 1148-1157.

Giesy, J.P., and Kannan, K., 2001, Global distribution of perfluorooctanesulfonate in wildlife:

Environmental Science and Technology, v. 35, p. 1339-1342.

Gilbert, M., Leclair, R., Jr., and Fortin, R., 1994, Reproduction of the northern leopard frog (Rana pipiens) in floodplain habitat in the Richelieu River, P. Quebec, Canada: Journal of Herpetology, v. 28:465-470.

Gillis, J.E., 1975, Characterization of a hybridizing complex of leopard frogs: Unpublished PhD Dissertation, Colorado State University, Fort Collins, Colorado.

Goldberg, S.R., Bursey, C.R., McKinnell, R.G., and Tan, I.S., 2001, Helminths of northern leopard frogs, Rana pipiens (Ranidae), from North Dakota and South Dakota: Western North American Naturalist, v. 61, p. 248-251.

Golden, D.R., Smith, G.R., and Rettig, J.E., 2001, Effects of age and group size on habitat selection and activity level in Rana pipiens tadpoles: Herpetological Journal, v. 11, p. 69-73.

Goldstein, M.I., Wilkins, R.N., and Lacher, T.E., Jr., 2005, Spatiotemporal responses of reptiles and amphibians to timber harvest treatments: Journal of Wildlife Management, v. 69, p. 525-539.

Green, D.E., Converse, K.A., and Schrader, A.K., 2002, Epizootiology of sixty-four amphibian morbidity and mortality events in the USA, 1996-2001: Annals of the New York Academy of Science, v. 969, p. 323-339.

Greenberg, C.H., 1994, Effects of high-intensity wildfire and silvicultural treatments on reptile communities in sand-pine scrub: Conservation Biology, v. 8, p. 1047-1057.

Gresswell, R.E., 1999, Fire and aquatic ecosystems in forested biomes of North America: Transactions of the American Fisheries Society, v. 128, p. 193-221.

Gross, J.A., Chen, T.H., and Karasov, W.H., 2007, Lethal and sublethal effects of chronic cadmium exposure on northern leopard frog (Rana pipiens) tadpoles: Environmental Toxicology and Chemistry, v. 26, p. 1192-1197.

Grube, A., Donaldson, D., Kiely, T., and Wu, L., 2011, Pesticides industry sales and usage: 2006 and 2007 market estimates: Biological and Economic Analysis Division, Office of Pesticide Programs, Office of Chemical Safety and Pollution Prevention, U.S. Environmental Protection Agency, Washington, D.C., 41 pp.

Grue, C.E., DeWeese, L.R., Mineau, P., Swanson, G.A., Foster, J.R., Arnold, P.M., Huckins, J.N., Sheehan, P.J., Marshall, W.K., and Ludden, A.P., 1986, Potential impacts of agricultural chemicals on waterfowl and other wildlife inhabiting prairie wetlands: an evaluation of research needs and approaches: Transactions of Northern American Wildlife Natural Resources Conference, v. 51, p. 357-383.

Hall, R.J., and Henry, P.F.P., 1992, Assessing effects of pesticides on amphibians and reptiles: status and needs: Herpetology Journal, v. 2, p. 65-71.

Hamilton, H.L., 1941, The biological action of rotenone of fresh water animals: Proceedings of the Iowa Academy of Science, v. 48, p. 467-479.

Hammerson, G.A., 1982, Bullfrog eliminating leopard frogs in Colorado?: Herpetological Review, v. 13, p. 115-116.

Hammerson, G.A., 1989, A field survey of amphibians in the Rocky Mountains of Colorado, August 1989: Unpublished report to the Colorado Division of Wildlife, Denver, Colorado. 
Hammerson, G.A., 1992, Field surveys of amphibians in the mountains of Colorado, 1991: Unpublished report to the Colorado Division of Wildlife and Colorado Field Office of The Nature Conservancy, Denver, Colorado.

Hammerson, G.A., 1999, Amphibians and reptiles in Colorado: $2^{\text {nd }}$ edition, University Press of Colorado, Boulder, xxvi+484 pp.

Harris, M.L., Bishop, C.A., Struger, J., van den Heuvel, M.R., Van der Kraak, G.J., Dixon, D.G., Ripley, B., and Bogart, J.P., 1998, The functional integrity of northern leopard frog (Rana pipiens) and green frog (Rana clamitans) populations in orchard wetlands. I. Genetics, physiology, and biochemistry of breeding adults and young-of-the-year: Environmental Toxicology and Chemistry, v. 17, p. 1338-1350.

Harris, M.L., Bishop, C.A., Struger, J., Ripley, B., and Bogart, J.P., 1998, The functional integrity of northern leopard frog (Rana pipiens) and green frog (Rana clamitans) populations in orchard wetlands. II. Effects of pesticides and eutrophic conditions on early life stage development: Environmental Toxicology and Chemistry, v. 17, p. 1351-1363.

Harte, J., and Hoffman, E., 1989, Possible effects of acidic deposition on a Rocky Mountain population of the tiger salamander Ambystoma tigrinum: Conservation Biology, v. 3, p. 149-158.

Hayes, M.P., and Jennings, M.R., 1986, Decline of ranid species in western North America: Are bullfrogs Rana catesbeiana responsible?: Journal of Herpetology, v. 20, p. 490-509.

Hayes, T., Collins, A., Lee, M., Mendoza, M., Noriega, M., Stewart, A.A., and Vonk, A., 2002, Hermaphroditic, demasculinized frogs after exposure to the herbicide atrazine at low ecologically relevant doses: Proceedings of the National Academy of Sciences, v. 99, p. 5476-5480.

Hayes, T., Haston, K., Tsui, M., Hoang, A., Haeffele, C., and Vonk, A., 2002, Feminization of male frogs in the wild: Nature, v. 419, p. 895-896.

Hayes, T., Haston, K., Tsui, M., Hoang, A., Haeffele, C., and Vonk, A., 2003, Atrazine-induced hermaphroditism at $0.1 \mathrm{ppb}$ in American Leopard Frogs (Rana pipiens): Laboratory and field evidence: Environmental Health Perspectives, v. 111, p. 568-575.

Hayes, T.B., Falso, P., Gallipeau, S., and Stice, M., 2010, The cause of global amphibian declines: a developmental endocrinologist's perspective: Journal of Experimental Biology, v. 213, p. 921-933.

Hecnar, S.J., 1995, Acute and chronic toxicity of ammonium-nitrate fertilizer to amphibians from southern Ontario: Environmental Toxicology and Chemistry, v. 14, p. 2131-2137.

Hecnar, S.J., and M’Closkey, R.T., 1996, Regional dynamics and the status of amphibians: Ecology, v. 77, p. 2091-2097.

Hecnar, S.J., and M’Closkey, R.T., 1997a, The effects of predatory fish on amphibian species richness and distribution: Biological Conservation, v. 79, p. 123-131.

Hecnar, S.J., and M'Closkey, R.T., 1997b, Changes in the composition of a ranid frog community following bullfrog extinction: American Midland Naturalist, v. 137, p. 145-150.

Hecnar, S.J., and M’Closkey, R.T., 1998, Species richness patterns of amphibians in southwestern Ontario ponds: Journal of Biogeography, v. 25, p. 763-772.

Helgen, J., McKinnell, R.G., and Gernes, M.C., 1998, Investigation of malformed northern leopard frogs in Minnesota: Pp. 288-297 in Lannoo, M.J., ed., Status and Conservation of Midwestern Amphibians, University of Iowa Press, Iowa City, Iowa, 507 pp.

Hendricks, F.S., 1973, Intestinal contents of Rana pipiens Schreber (Ranidae) larvae: Southwestern Naturalist, v. 18, p. 99-101.

Hermes-Lima, M., and Storey, K.B., 1998, Role of antioxidant defenses in the tolerance of severe dehydration by anurans. The case of the leopard frog Rana pipiens: Molecular and Cellular Biochemistry, v. 189, p. 79-89. 
Hillis, D.M., 1988, Systematics of the Rana pipiens complex: puzzle and paradigm: Annual Review of Ecology and Systematics, v. 19, p. 39-63.

Hillis, D.M., 2007, Constraints in naming parts of the Tree of Life: Molecular Phylogenetics and Evolution, v. 42, p. 331-338.

Hillis, D.M., Frost, J.S., and Wright, D.A., 1983, Phylogeny and biogeography of the Rana pipiens complex: a biochemical evaluation: Systematic Zoology, v. 32, p. 132-143.

Hine, R.L., Les, B.L., and Hellmich, B.F., 1981, Leopard frog populations and mortality in Wisconsin: Wisconsin Department of Natural Resources Technical Bulletin No. 122, p. 1-139.

Hoffman, E.A., and Blouin, M.S., 2004, Evolutionary history of the northern leopard frog: reconstruction of phylogeny, phylogeography, and historical changes in population demography from mitochondrial DNA: Evolution, v. 58, p. 145-159.

Hoffman, E.A., Schueler, F.W., and Blouin, M.S., 2004, Effective population sizes and temporal stability of genetic structure in Rana pipiens, the northern leopard frog: Evolution, v. 58, p. 25362545.

Hupf, T.H., 1977, Natural histories of two species of leopard frogs, Rana blairi and Rana pipiens, in a zone of sympatry in northeastern Nebraska: Unpublished M.S. Thesis, University of Nebraska, Lincoln, Nebraska, 125 pp.

Hunter, B.R., Carlson, D.L., Seppan, E.D., Killian, P.S., McKinnell, B.K., and McKinnell, R.G., 1989, Are renal carcinomas increasing in Rana pipiens after a decade of reduced prevalence?: American Midland Naturalist, v. 122, p. 307-312.

Irving, E.C., Lowell, R.B., Culp, J.M., Liber, K., Xie, Q., and Kerrich, R., 2008, Effects of arsenic speciation and low dissolved oxygen condition on toxicity of arsenic to a lotic mayfly: Environmental Toxicology and Chemistry, v. 27, p. 583-590.

Jancovich, J.K., Davidson, E.W., Morado, J.F., Jacobs, B.L., and Collins, J.P., 1997, Isolation of a lethal virus from the endangered tiger salamander Ambystoma tigrinum stebbinsi: Diseases of Aquatic Organisms, v. 31, p. 161-167.

Jeffries, D.L., and Klopatek, J.M., 1987, Effects of grazing on the vegetation of the blackbrush association: Journal of Range Management, v. 40, p. 390-392.

Jennings, M.R., and Fuller, M.M., 2004, Origin and distribution of leopard frogs, Rana pipiens complex, in California: California Fish and Game, v. 90, p. 119-139.

Jofre, M.B., Rosenshield, M.L., and Karasov, W.H., 2000, Effects of PCB 126 and ammonia, alone and in combination, on green frog (Rana clamitans) and leopard frog (Rana pipiens) hatching success, development, and metamorphosis: Journal of the Iowa Academy of Science, v. 107, p. 113-122.

Johnson, P.T.J., and Lunde, K.B., 2005, Parasite infection and limb malformations: a growing problem in amphibian conservation: Pp. 124-138 in Lannoo, M., ed., Amphibian declines: the conservation status of United States species: University of California Press, Berkeley, California, 1094 pp.

Johnson, P.T.J., Lunde, K.B., Ritchie, E.G., and Launer, A.E., 1999, The effect of trematode infection on amphibian limb development and survivorship: Science, v. 284, p. 802-804.

Johnson, W.C., Werner, B., Guntenspergen, G.R., Roldseth, R.A., Millett, B., Naugle, D.E., Tulbure, M., Carroll, R.W.H., Tracy, J., and Olawsky, C., 2010, Prairie wetland complexes as landscape functional units in a changing climate: Bioscience, v. 60, p. 128-140.

Joly, P., Miaud, C., Lehmann, A., and Grolet, O., 2001, Habitat matrix effects on pond occupancy in newts: Conservation Biology, v. 15, p. 239-248.

Jones, B., Fox, S.B., Leslie, D.M., Jr., Engle, D.M., and Lochmiller, R.L., 2000, Herpetofaunal responses to brush management with herbicide and fire: Journal of Range Management, v. 53, p. 154158. 
Jones, D.K., Hammond, J.I., and Relyea, R.A., 2009, Very highly toxic effects of endosulfan across nine species of tadpoles: lag effects and family-level sensitivity: Environmental Toxicology and Chemistry, v. 28, p. 1939-1945.

Kaplan, H.M., and Glaczenski, S.S., 1965, Hematological effects of organophosphate insecticides in the frog (Rana pipiens): Life Sciences, v. 4, p. 1213-1219.

Karasov, W.H., Jung, R.E., Vanden Langenberg, S., and Bergeson, T.L.E., 2005, Field exposure of frog embryos and tadpoles along a pollution gradient in the Fox River and Green Bay ecosystem in Wisconsin, USA: Environmental Toxicology and Chemistry, v. 24, p. 942-953.

Karns, D.R., 1992, Effects of acidic bog habitats on amphibian reproduction in a northern Minnesota peatland: Journal of Herpetology, v. 26, p. 401-412.

Kats, L.B., Petranka, J.W., and Sih, A., 1988, Antipredator defenses and the persistence of amphibian larvae with fishes: Ecology, v. 69, p. 1865-1870.

Kauffman, J., and Krueger, W.C., 1984, Livestock impacts on riparian ecosystems and streamside management implications: a review: Journal of Range Management, v. 37, p. 430-437.

Kendell, K., 2002a, Investigation of northern leopard frog (Rana pipiens) over-wintering ecological requirements: Alberta Environment, Fisheries and Wildlife Management Division, Edmonton, Alberta, 52 pp.

Kendell, K., 2002b, Survey protocol for the northern leopard frog: Alberta Species at Risk Report, No. 43, $42 \mathrm{pp}$.

Kimberling, D.N., Ferreira, A.R., Shuster, S.M., and Keim, P., 1996, RAPD marker estimation of genetic structure among isolated northern leopard frog populations in the south-western USA: Molecular Ecology, v. 5, p. 521-529.

Kimbrough, R.A., and Litke, D.W., 1996, Pesticides in streams draining agricultural and urban areas in Colorado: Environmental Science and Technology, v. 30, p. 908-916.

King, K.C., Gendron, A.D., McLaughlin, J.D., Giroux, I., Brousseau, P., Cyr, D., Ruby, S.M., Fournier, M., and Marcogliese, D.J., 2008, Short-term seasonal changes in parasite community structure in northern leopard froglets (Rana pipiens) inhabiting agricultural wetlands: Journal of Parasitology, v. 94, p. 13-22.

Knutson, M.G., Richardson, W.B., Reineke, D.M., Gray, B.R., Parmelee, J.R., and Weick, S.E., 2004, Agricultural ponds support amphibian populations: Ecological Applications, v. 14, p. 669-684.

Koch, E.G., Williams, G., Peterson, C.R., and Corn, P.S., 1996, A summary of the Conference on Declining and Sensitive Amphibians in the Rocky Mountains and Pacific Northwest: Idaho Herpetological Society and U.S. Fish and Wildlife Service, Snake River Basin Office Report, Boise, Idaho.

Kolozsvary, M.B., and Swihart, R.K., 1999, Habitat fragmentation and the distribution of amphibians: patch and landscape correlates in farmland: Canadian Journal of Zoology, v. 77, p. 1288-1299.

Koonz, W.H., 1992, Amphibians in Manitoba: Pp. 19-20 in Bishop, C.A., and Petits, K.E., eds., Declines in Canadian amphibian populations: designing a national monitoring strategy: Canadian Wildlife Series Occasional Papers, No. 75, Ottawa, Ontario, 120 pp.

Kosian, P.A., Makynen, E.A., Ankley, G.T., and Degitz, S.J., 2003, Uptake and metabolism of all-trans retinoic acid by three native North American ranids: Toxicological Sciences, v. 74, p. 147-156.

Langen, T.A., Machniak, A., Crowe, E.K., Mangan, C., Marker, D.F., Liddle, N., and Roden, B., 2007, Methodologies for surveying herpetofauna mortality on rural highways: Journal of Wildlife Management, v. 71, p. 1361-1368. 
Lannoo, M.J., Lang, K., Waltz, T., and Phillips, G.S., 1994, An altered amphibian assemblage Dickinson County, Iowa, 70-years after Blanchard, Frank Survey: American Midland Naturalist, v. 131, p. 311-319.

Lehtinen, R.M., Galatowitsch, S.M., and Tester, J.R., 1999, Consequences of habitat loss and fragmentation for wetland amphibian assemblages: Wetlands, v. 19, p. 1-12.

Leney, J.L., Balkwill, K.C., Drouillard, K.G., and Haffner, G.D., 2006, Determination of polychlorinated biphenyl and polycyclic aromatic hydrocarbon elimination rates in adult green and leopard frogs: Environmental Toxicology and Chemistry, v. 25, p. 1627-1634.

Leonard, W.P., McAllister, K.R., and Friesz, R.C., 1999, Survey and assessment of northern leopard frog (Rana pipiens) populations in Washington state: Northwestern Naturalist, v. 80, p. 51-60.

Licht, L.E., 1991, Habitat selection of Rana pipiens and Rana sylvatica during exposure to warm and cold temperatures: American Midland Naturalist, v. 125, p. 259-268.

Linder, G., and Grillitsch, B., 2000, Ecotoxicology of metals: Pp. 325-459 in Sparling, D.W., Linder, G., and Bishop, C.A., eds., Ecotoxicology of Amphibians and Reptiles, SETAC Press, Pensacola, Florida, 877 pp.

Linzey, D.W., 1967, Food of the northern leopard frog, Rana pipiens pipiens, in central New York: Herpetologica, v. 23, p. 11-17.

Liss, W.J., and Larson, G.L., 1991, Ecological effects of stocked trout on North Cascades naturally fishless lakes: Park Science, v. 11, p. 22-23.

Livo, L.J., 1981, Leopard frog (Rana pipiens) reproduction in Boulder County, Colorado: Unpublished M.A. Thesis, University of Colorado, Denver, Colorado.

Livo, L.J., 1995, Amphibian surveys in Boulder, Clear Creek, and Gilpin counties, Colorado, 1994: Unpublished report, Colorado Division of Wildlife, Denver, Colorado.

Livo, L.J., Hammerson, G.A., and Smith, H.M., 1998, Summary of amphibians and reptiles introduced into Colorado: Northwestern Naturalist, v. 79, p. 1-11.

Long, L.E., Saylor, L.S., and Soule, M.E., 1995, A pH/UV-B synergism in amphibians: Conservation Biology, v. 9, p. 1301-1303.

Longcore, J.R., Longcore, J.E., Pessier, A.P., and Halteman, W.A., 2007, Chytridiomycosis widespread in anurans of northeastern United States: Journal of Wildlife Management, v. 71, p. 435-444.

Lynch, J.D., 1978, The distribution of leopard frogs (Rana blairi and Rana pipiens)(Amphibia, Anura, Ranidae) in Nebraska: Journal of Herpetology, v. 12, p. 157-162.

Maisonneuve, C., and Rioux, S., 2001, Importance of riparian habitats for small mammals and herpetofaunal communities in agricultural landscapes of southern Quebec: Agricultural Ecosystems and Environment, v. 83, p. 165-175.

Manion, J.J., and Cory, L., 1952, Winter kill of Rana pipiens in shallow ponds: Herpetologica, v. 8, p. 32.

Maxell, B.A., 2000, Management of Montana’s amphibians: a review of factors that may present a risk to population viability and accounts on the identification, distribution, taxonomy, habitat use, natural history, and the status and conservation of individual species: Report to USFS Region 1, Order No. 43-0343-0-0224: University of Montana, Wildlife Biology Program, Missoula, Montana, $161 \mathrm{pp}$. Available online at http://www.fs.fed.us/r1/wildlife/ecology/montana\%20amphibian\%20guidlines.pdf Maxell, B.A., 2009, State-wide assessment of status, predicted distribution, and landscape-level habitat suitability of amphibians and reptiles in Montana: PhD Dissertation, University of Montana, $309 \mathrm{pp}$. Mazerolle, M.J., 2001, Amphibian activity, movement patterns, and body size in fragmented peat bogs: Journal of Herpetology, v. 35, p. 13-20. 
Mazerolle, M.J., and Desrochers, A., 2005, Landscape resistance to frog movements: Canadian Journal of Zoology, v. 83, p. 455-464.

McAllister, C., 2007, The effects of recreational trail design and management decisions on northern leopard frog (Rana pipiens) populations in an urban park: Unpublished Master's Thesis, University of Waterloo, Waterloo, Ontario, Canada, 107 pp.

McAllister, K.R., Leonard, W.P., Hays, D.W., and Friesz, R.C., 1999, Washington state status report for the northern leopard frog: Washington Department of Fish and Wildlife, Wildlife Management Program, Olympia, Washington, 45 pp.

McAlpine, D.F., and Dilworth, T.G., 1989, Microhabitat and prey size among three species of Rana (Anura: Ranidae) sympatric in eastern Canada: Canadian Journal of Zoology, v. 67, p. 2244-2252.

McClelland, B.E., and Wilczynski, W., 1989, Release call characteristics of male and female Rana pipiens: Copeia, v. 1989, p. 1045-1049.

McCollum, S.A., and Gates, J.E., 1997, Predator-induced morphological changes in an amphibian: predation by dragonflies affects tadpole shape and color: Oecologia, v. 109, p. 615-621.

McComb, W.C., McGarigal, K., and Anthony, R.G., 1993, Small mammal and amphibian abundance in streamside and upslope habitats of mature Douglas-fir stands, western Oregon: Northwest Science, v. 67, p. 7-15.

McLeod, R., and Gates, J.E., 1998, Response of herpetofaunal communities to forest cutting and burning at Chesapeake Farms, Maryland: American Midland Naturalist, v. 139, p. 164-177.

McDaniel, T.V., Harris, M.L., Bishop, C.A., and Struger, J., 2004, Development and survivorship of northern leopard frogs (Rana pipiens) and green frogs (Rana clamitans) exposed to contaminants in the water and sediments of the St. Lawrence River near Cornwall, Ontario: Water Quality Research Journal of Canada, v. 39, p. 160-174.

McDaniel, T.V., Martin, P.A., Struger, J., Sherry, J., Marvin, C.H., McMaster, M.E., Clarence, S., and Tetreault, G., 2008, Potential endocrine disruption of sexual development in free ranging male northern leopard frogs (Rana pipiens) and green frogs (Rana clamitans) from areas of intensive row crop agriculture: Aquatic Toxicology, v. 88, p. 230-242.

McKinnell, R.G., 1973, The Lucke frog kidney tumour and its herpevirus: American Zoologist, v. 13, p. 97-114.

Means, D.B., and Campbell, H.W., 1982, Effects of prescribed burning on amphibians and reptiles: Pp. 89-97 in Wood, G.W., ed., Prescribed fire and wildlife in southern forests, The Belle W. Baruch Forest Science Institute, Georgetown, South Carolina.

Merrell, D.J., 1968, A comparison of the estimated size and the "effective size" of breeding populations of the leopard frog, Rana pipiens: Evolution, v. 22, p. 274-283.

Merrell, D.J., 1969, Natural selection in a leopard frog population: Journal of the Minnesota Academy of Science, v. 35, p. 86-89.

Merrell, D.J., 1970, Migration and gene dispersal in Rana pipiens: American Zoologist, v. 10, p. 47-52. Merrell, D.J., 1977, Life history of the leopard frog, Rana pipiens, in Minnesota: Bell Museum of Natural History Occasional Papers No. 15, p. 1-23.

Merrell, D.J., and Rodell, C.F., 1968, Seasonal selection in the leopard frog, Rana pipiens: Evolution, v. 22, p. 284-288.

Meteyer, C.U., Loeffler, I.K., Fallon, J.F., Converse, K.A., Green, E., Helgen, J.C., Kersten, S., Levey, R., Eaton-Poole, L., and Burkhart, J.G., 2000, Hind limb malformations in free-living northern leopard frogs (Rana pipiens) from Maine, Minnesota, and Vermont suggest multiple etiologies: Teratology, v. 62, p. 151-171. 
Meyer-Aurich, A., Zander, P., Werner, A., and Roth, R., 1998, Developing agricultural land use strategies appropriate to nature conservation goals and environmental protection: Landscape and Urban Planning, v. 41, p. 119-127.

Milius, S., 2000, New frog-killing disease may not be so new: Science News, v. 157, p. 133.

Miller, J.D., 1978, Observations on the diets of Rana pretiosa, Rana pipiens, and Bufo boreas from western Montana: Northwest Science, v. 52, p. 243-249.

Minshall, G.W., 2003, Responses of stream benthic macroinvertebrates to fire: Forest Ecology and Management, v. 178, p. 155-161.

Mix, K., Rast, W., and Lopes, V.L., 2010, Increases in growing degree days in the alpine desert of the San Luis Valley, Colorado: Water, Air, and Soil Pollution, v. 205, p. 289-304.

Morell, V., 1999, Are pathogens felling frogs?: Science, v. 284, p. 728-731.

Morin, P.J., 1983, Predation, competition, and the composition of larval anuran guilds: Ecological Monographs, v. 53, p. 119-138.

Moseley, K.R., Castleberry, S.B., and Schweitzer, S.H., 2003, Effects of prescribed fire on herpetofauna in bottomland hardwood forests: Southeastern Naturalist, v. 2, p. 475-486.

Mushinsky, H.R., 1985, Fire and the Florida sandhill herpetofaunal community: with special attention to responses of Cnemidophorus sexlineatus: Herpetologica, v. 41, p. 333-342.

Muths, E., Corn, P.S., Pessier, A.P., and Green, D.E., 2003, Evidence for disease-related amphibian decline in Colorado: Biological Conservation, v. 110, p. 357-365.

Nace, G.W., Culley, D.D., Emmons, M.B., Gibbs, E.L., Hutchison, V.H., and McKinnell, R.G., 1996, Amphibians: guidelines for the breeding, care and management of laboratory animals: A report of the Subcommittee on Amphibian Standards, Committee on Standards, Institute of Laboratory Animal Resources and National Research Council National Academy of Sciences, Washington, D.C.

Nash, R.F., Gallup, G.G., and McClure, M.K., 1970, The immobility reaction in leopard frogs (Rana pipiens) as a function of noise-induced fear: Psychonometric Science, v. 21, p. 155-156.

Nelson, J.K., 1999, Monitoring frog and toad populations using vocalization surveys at Rocky Flats Environmental Technology Site, Colorado: Journal of the Colorado-Wyoming Academy of Sciences, v. 31, p. 11.

Northern Prairie Wildlife Research Center, 1997, North American Reporting Center for Amphibian Malformations: Jamestown, North Dakota, Northern Prairie Wildlife Research Center Home Pate, http://www.nbii.gov/narcam, accessed 1 June 2011.

O’Connor, M.P., and Tracy, C.R., 1988, Dependence of body temperatures and evaporative water loss on environmental factors in basking leopard frogs (Rana pipiens): American Zoologist, v. 28, p. A130.

Ouellet, M., Bonin, J., Rodrigue, J., DesGranges, J.L., and Lair, S., 1997, Hindlimb deformities (ectromelia, ectrodactyly) in free-living anurans from agricultural habitats: Journal of Wildlife Diseases, v. 33. P. 95-104.

Pace, A.E., 1974, Systematic and biological studies of the leopard frogs (Rana pipiens complex) of the United States: Museum of Zoology, University of Michigan, 152 pp.

Parris, M.J., 1998, Terrestrial burrowing ecology of newly metamorphosed frogs (Rana pipiens complex): Canadian Journal of Zoology, v. 76, p. 2124-2129.

Parris, M.J., 2000, Experimental analysis of hybridization in leopard frogs (Anura: Ranidae): Larval performance in desiccating environments: Copeia, v. 1, p. 11-19.

Parris, M.J., Reese, E., and Storfer, A., 2006, Antipredator behavior of chytridiomycosis-infected northern leopard frog (Rana pipiens) tadpoles: Canadian Journal of Zoology, v. 84, p. 48-65. 
Parsons, R.H., Thorn, L.M., Salerno, S.M., and Petronis, S., 1990, Salt load effects on osmotic water flow, tritiated water diffusion, and the cardiovascular system in Rana pipiens and Rana catesbeiana: Physiological Zoology, v. 63, p. 571-586.

Patla, D.A., 2005, Protecting amphibians while restoring fish populations: Pp. 275-276 in Lannoo, M., ed., Amphibian declines: the conservation status of United States species, University of California Press, Berkeley, California, 1094 pp.

Pauli, B.D., Coulson, D.R., and Berrill, M., 1999, Sensitivity of amphibian embryos and tadpoles to Mimic (R) 240 LV insecticide following single or double exposures: Environmental Toxicology and Chemistry, v. 18, p. 2538-2544.

Pauli, B.D., Perrault, J.A., and Money, S.L., 2000, RATL: a database of reptile and amphibian toxicology literature: Technical Report Series No. 357E, Canadian Wildlife Service, Headquarters, Hull, PQ, Canada;

Pechmann, J.H.K., and Wilber, H.M., 1994, Putting declining amphibian populations in perspective: natural fluctuations and human impacts: Herpetologica, v. 50, p. 65-84.

Pechmann, J.H.K., Estes, R.A., Scott, D.E., and Gibbons, J.W., 2001, Amphibian colonization and use of ponds created for trial mitigation of wetland loss: Wetlands, v. 21, p. 93-111.

Pechmann, J.H.K., Scott, D.E., Semlitsch, R.D., Caldwell, J.P., Vitt, L.J., and Gibbons, J.W., 1991, Declining amphibian populations: the problem of separating human impacts and natural fluctuations: Science, v. 253, p. 892-895.

Phaneuf, D., DesGranges, J.L., Plante, H., and Rodrigue, J., 1995, Contamination of local wildlife following a fire at a polychlorinated biphenyls warehouse in St. Basile le Grand, Quebec, Canada: Archives of Environmental Contamination and Toxicology, v. 28, p. 145-153.

Pilliod, D.S., Bury, R.B., Hyde, E.J., Pearl, C.A., and Corn, P.S., 2003, Fire and amphibians in North America: Forest Ecology and Management, v. 178, p. 163-181.

Pope, S.E., Fahrig, L., and Merriam, H.G., 2000, Landscape complementation and metapopulation effects on leopard frog populations: Ecology, v. 81, p. 2498-2508.

Porter, K.R., and Hakanson, D.E., 1976, Toxicity of mine drainage to embryonic and larval boreal toads (Bufonidae: Bufo boreas): Copeia, v. 1976, p. 327-331.

Post, D.D., 1972, Species differentiation in the Rana pipiens complex: Unpublished PhD Dissertation, Colorado State University, Fort Collins, Colorado.

Powder River Basin Resource Council, 2002, Draft EIS (Powder River Basin): Available online at http://www.powderriverbasin.org/draft-eis-powder-river-basin/. Accessed online 3 June 2011.

Ralph, S., and Petras, M., 1997, Genotoxicity monitoring of small bodies of water using two species of tadpoles and the alkaline single cell gel (comet) assay: Environmental and Molecular Mutagenesis, v. 29, p. 418-430.

Ramirez, P., Jr., 2002, Oil field produced water discharges into wetlands in Wyoming: U.S. Fish and Wildlife Service Contaminant Report \#R6/718C/02, 19 pp.

Relyea, R.A., 2001a, Morphological and behavioral plasticity of larval anurans in response to different predators: Ecology, v. 82, p. 523-540.

Relyea, R.A., 2001b, The relationship between predation risk and antipredator responses in larval anurans: Ecology, v. 82, p. 541-554.

Relyea, R.A., 2005, The lethal impacts of roundup and predatory stress on six species of North American tadpoles: Archives of Environmental Contamination and Toxicology, v. 48, p. 351-357.

Relyea, R., and Hoverman, J., 2006, Assessing the ecology in ecotoxicology: a review and synthesis in freshwater systems: Ecology Letters, v. 9, p. 1157-1171. 
Relyea, R.A., and Werner, E.E., 2000, Morphological plasticity in four larval anurans distributed along an environmental gradient: Copeia, v. 2000, p. 178-190.

Richards, C.M., 1958, The inhibition of growth in crowded Rana pipiens tadpoles: Physiological Zoology, v. 31, p. 138-151.

Rittschoff, D., 1975, Some aspects of the natural history and ecology of the leopard frog, Rana pipiens: Ph.D. Thesis, University of Michigan, 212 pp.

Rollins-Smith, L.A., Carey, C., Longcore, J., Doersam, J.K., Boutte, A., Bruzgal, J.E., and Conlon, J.M., 2002, Activity of antimicrobial skin peptides from ranid frogs against Batrachochytrium dendrobatidis, the chytrid fungus associated with global amphibian declines: Developmental and Comparative Immunology, v. 26, p. 471-479.

Rorabaugh, J.C., 2005, Rana pipiens: Pp. 570-580 in Lannoo, M., ed., Amphibian Decline: The Conservation Status of North American Species, University of California Press, Berkeley, California. Rosenshield, M.L., Jofre, M.B., and Karasov, W.H., 1999, Effects of polychlorinated biphenyl 126 on green frog (Rana clamitans) and leopard frog (Rana pipiens) hatching success, development, and metamorphosis: Environmental Toxicology and Chemistry, v. 18, p. 2478-2486.

Rouse, J.D., Bishop, C.A., and Struger, J., 1999, Nitrogen pollution: an assessment of its threat to amphibian survival: Environmental Health Perspectives, v. 107, p. 799-803.

Rudolph, D.C., and Dickson, J.G., 1990, Streamside zone width and amphibian and reptile abundance: Southwestern Naturalist, v. 35, p. 472-476.

Ruiz, A.M., Maerz, J.C., Davis, A.K., Keel, M.K., Ferreira, A.R., Conroy, M.J., Morris, L.A., and Fisk, A.R., 2010, Patterns of development and abnormalities among tadpoles in a constructed wetland receiving treated wastewater: Environmental Science and Technology, v. 44, p. 4862-4868.

Russell, K.R., Van Lear, D.H., and Guynn, D.C., Jr., 1999, Prescribed fire effects on herpetofauna: review and management implications: Wildlife Society Bulletin, v. 27, p. 374-384.

Samson, F.B., Knopf, F.L., McCarthy, C.W., Noon, B.R., Ostlie, W.R., Rinehart, S.M., Larson, S., Plumb, G.E., Schenbeck, G.L., Svingen, D.N., and Byer, T.W., 2003, Planning for population viability on northern great plains national grasslands: Wildlife Society Bulletin, v. 31, p. 986-999.

Schlicter, L.C., 1981, Low pH affects the fertilization and development of Rana pipiens eggs: Canadian Journal of Zoology, v. 59, p. 1693-1699.

Schock, D.M., and Bollinger, T.K., 2005, An apparent decline of northern leopard frogs (Rana pipiens) on the Rafferty Dam Mitigation Lands enar Estevan, Saskatchewan: Blue Jay, v. 63, p. 144-154.

Schock, D.M., Bollinger, T.K., Chinchar, V.G., Jancovich, J.K., and Collins, J.P., 2008, Experimental evidence that amphibian ranaviruses are multi-host pathogens: Copeia, v. 1, p. 133-143.

Schotthoefer, A.M., Koehler, A.V., Meteyer, C.U., and Cole, R.A., 2003, Influence of Ribeiroia ondatrae (Trematoda: Digenea) infection on limb development and survival of northern leopard frogs (Rana pipiens): effects of host stage and parasite-exposure level: Canadian Journal of Zoology, v. 81, p. 1144-1153.

Schurbon, J.M., and Fauth, J.E., 2003, Effects of prescribed burning on amphibian diversity in a southeastern U.S. national forest: Conservation Biology, v. 117, p. 1338-1349.

Schuytema, G.S., Nebeker, A.V., Griffis, W.L., and Wilson, K.N., 1991, Teratogenesis, toxicity, and bioconcentration in frogs exposed to dieldrin: Archives of Environmental Contamination and Toxicity, v. 21, p. 332-350.

Seburn, C.N.L., Seburn, D.C., and Paszkowski, C.A., 1997, Northern leopard frog (Rana pipiens) dispersal in relation to habitat: Pp. 64-72 in Green, D.M., ed., Amphibians in Decline: Canadian Studies of a Global Problem, Society for the Study of Amphibians and Reptiles, Herpetological Conservation Number One, St. Louis, Missouri, 338 pp. 
Semlitsch, R.D., 1998, Biological delineation of terrestrial buffer zones for pond-breeding salamanders: Conservation Biology, v. 12, p. 1112-1119.

Semlitsch, R.D., 2000a, Principles for management of aquatic-breeding amphibians: Journal of Wildlife Management, v. 64, p. 615-631.

Semlitsch, R.D., 2000b, Size does matter: the value of small isolated wetlands: National Wetlands Newsletter, January-February, v. 2000, p. 5-13.

Semlitsch, R.D., and Bodie, J.R., 1998, Are small, isolated wetlands expendable?: Conservation Biology, v. 12, p. 1129-1133.

Sexton, O.J., and Phillips, C., 1986, A qualitative study of fish-amphibian interactions in three Missouri ponds: Transactions of the Missouri Academy of Science, v. 20, p. 25-35.

Shaffer, H.B., and Juterbock, J.E., 1994, Night driving: Pp. 163-166 in Heyer, W.R., Donnelly, M.A., McDiarmid, R.W., Hayek, L.C., and Foster, M.C., eds., Measuring and Monitoring Biological Diversity: Standard Methods for Amphibians, Smithsonian Institution Press, Washington, D.C., 364 pp.

Simon, M.P., Vatnick, I., Hopey, H.A, Butler, K., Korver, C., Hilton, C., Weiman, R.S., and Brodkin, M.A., 2002, Effects of acid exposure on natural resistance and mortality of adult Rana pipiens: Journal of Herpetology, v. 36, p. 697-699.

Smith, B.E., 2003, Conservation assessment for the northern leopard frog in the Black Hills National Forest South Dakota and Wyoming: United States Department of Agriculture, Forest Service, Rocky Mountain Region, Black Hills National Forest, Custer, South Dakota, 82 pp.

Smith, B.E., and Keinath, D., 2004, Species assessment for the northern leopard frog (Rana pipiens) in Wyoming: United States Department of Interior, Bureau of Land Management, Wyoming State Office, Cheyenne, Wyoming, 105 pp.

Smith, B.E., and Keinath, D.A., 2007, Northern leopard frog (Rana pipiens): a technical conservation assessment: Report prepared for the USDA Forest Service, Rocky Mountain Region, Species Conservation Project, 67 pp.

Sowers, A.D., Mills, M.A., and Klaine, S.J., 2009, The developmental effects of a municipal wastewater effluent on the northern leopard frog, Rana pipiens: Aquatic Toxicology, v. 94, p. 145-152.

Sparling, D.W., Linder, G., and Bishop, C.A., eds., 2000, Ecotoxicology of amphibians and reptiles: SETAC Press, Pensacola, Florida, 877 pp.

Sparling, D.W., Krest, S.K., Linder, G., 2001, Multiple stressors and declining amphibian populations: an integrated analysis of cause-effect to support adaptive resource management: Pp. 1-7 in Linder, G., Krest, S.K., and Sparling, D.W. (editors): Amphibian decline: an integrated analysis of multiple stressor effects. Racine, Wisconsin.

Sparling, D.W., Linder, G., Bishop, C.A., and Krest, S.K., eds., 2010, Ecotoxicology of amphibians and reptiles, $2^{\text {nd }}$ edition: CRC Press, Taylor \& Francis Group, Boca Raton, Florida, 916 pp.

Stabenau, E.K., Giczewski, D.T., and Maillacheruvu, K.Y., 2006, Uptake and elimination of naphthalene from liver, lung, and muscle tissue in the leopard frog (Rana pipiens): Journal of Environmental Science and Health Part A - Toxic/Hazardous Substances and Environmental Engineering, v. 41, p. 1449-1461.

Stabenau, E.K., Sasser, A., and Schulte, C., 2008, The effects of pyrene exposure on exercise performance, muscle contraction, and mitochondrial O-2 consumption in the leopard frog (Rana pipiens): Journal of Environmental Science and Health Part A - Toxic/Hazardous Substances and Environmental Engineering, v. 43, p. 576-583.

Stebbins, R.C., 2003, A field guide to western reptiles and amphibians, $3^{\text {rd }}$ edition: Houghton Mifflin Harcourt, Boston, Massachusetts, 560 pp. 
Stevens, C.E., Diamond, A.W., and Gabor, T.S., 2002, Anuran call surveys on small wetlands in Prince Edward Island, Canada restored by dredging of sediments: Wetlands, v. 22, p. 90-99.

Sutherland, D., 2005, Parasites of North American frogs: Pp. 109-123 in Lannoo, M., ed., Amphibian declines: the conservation status of United States species, University of California Press, Berkeley, California, 1094 pp.

Tiner, R.W., Jr., 1984, Wetlands of the United States: current status and recent trends: National Wetlands Inventory, U.S. Department of the Interior, U.S. Fish and Wildlife Service, 76 pp.

Trombulak, S.C., and Frissell, C.A., 2000, Review of ecological effects of roads on terrestrial and aquatic communities: Conservation Biology, v. 14, p. 18-30.

Trumbo, J., 2005, An assessment of the hazard of a mixture of the herbicide Rodeo (R) and the nonionic surfactant R-11 (R) to aquatic invertebrates and larval amphibians: California Fish and Game, v. 91, p. 38-46.

Turner, R.E., Redmond, A.M., and Zedler, J.B., 2001, Count it by acre or function-mitigation adds up to net loss of wetlands: National Wetlands Newsletter, v. 23, p. 5-16.

Ultsch, G.R., Graham, T.E., and Crocker, C.E., 2000, An aggregation of overwintering leopard frogs, Rana pipiens, and common map turtles, Graptemys geographica, in northern Vermont: Canadian Field-Naturalist, v. 114, p. 314-315.

Ultsch, G.R., Reese, S.A., and Stewart, E.R., 2004, Physiology of hibernation in Rana pipiens: metabolic rate, critical oxygen tension, and the effects of hypoxia on several plasma variables: Journal of Experimental Zoology Part A - Comparative Experimental Biology, v. 301A, p. 169-176.

U.S. EPA, 1998, Staff background paper \#5.1, Summary of organophosphate pesticide usage, Tolerance Reassessment Advisory Committee, TRAC 5/27/98, 2 p.

USFS, 2004a, Environmental assessment, Yates Petroleum Corporation Thunder Basin Coal Bed Methane Development Project: USDA Forest Service, Medicine Bow-Routt National Forests and Thunder Basin National Grassland, Douglas, Wyoming.

USFS, 2004b, Environmental assessment, Lance Oil and Gas Company Thunderhead Project: Medicine Bow-Routt National Forests and Thunder Basin National Grassland, Douglas, Wyoming.

USFS 2004c, Environmental assessment, Big Porcupine Project: Medicine Bow-Routt National Forests and Thunder Basin National Grassland, Douglas, Wyoming.

U.S. Fish and Wildlife Service, 2009, Endangered and threatened wildlife and plants; 90-day finding on a petition to list the northern leopard frog (Lithobates [=Rana] pipiens) in the western United States as threatened: Federal Register, v. 74, p. 31389-31401.

Vandenlangenberg, S.M., Canfield, J.T., and Magner, J.A., 2003, A regional survey of malformed frogs in Minnesota (USA): Environmental Monitoring and Assessment, v. 82, p. 45-61.

Vatnick, I., Brodkin, M.A., Simon, M.P., Grant, B.W., Conte, C.R., Gleave, M., Myers, R., and Sadoff, M.M., 1999, The effects of exposure to mild acidic conditions on adult frogs (Rana pipiens and Rana clamitans): mortality rates and pH preferences: Journal of Herpetology, v. 33, p. 370-374.

Vertucci, F.A., and Corn, P.S., 1996, Evaluation of episodic acidification and amphibian declines in the Rocky Mountains: Ecological Applications, v. 6, p. 449-457.

Voordouw, M.J., Adama, D., Houston, B., Govindarajulu, P., and Robinson, J., 2010, Prevalence of the pathogenic chytrid fungus, Batrachochytrium dendrobatidis, in an endangered population of northern leopard frogs, Rana pipiens: BMC Ecology, v. 10, p. 1-10.

Wallace, J.E., Steidl, R.J., and Swann, D.E., 2010, Habitat characteristics of lowland leopard frogs in mountain canyons of southeastern Arizona: Journal of Wildlife Management, v. 74, p. 808-815. 
Wauchope, R.D., Buttler, T.M., Hornsby, A.G., Augustijn-Beckers, P.W., and Burt, J.P., 1992, The SCS/ARS/CES pesticide properties database for environmental decision-making: Reviews of Environmental Contaminants and Toxicology, v. 123, p. 1-155.

Welsh, H.H., Jr., and Ollivier, L.M., 1998, Stream amphibians as indicators of ecosystem stress: a case study from California’s redwoods: Ecological Applications, v. 8, p. 1119-1132.

Werner, E.E., 1992, Competitive interactions between wood frog and northern leopard frog larvae - the influence of size and activity: Copeia, v. 1, p. 26-35.

Werner, J.K., 2003, Status of the northern leopard frog (Rana pipiens) in western Montana: Northwestern Naturalist, v. 84, p. 24-30.

Wetzel, R.G., 1983, Limnolgy, $2^{\text {nd }}$ edition: Saunders College Publishing, Fort Worth, Texas.

Whitaker, J.O., Jr., 1961, Habitat and food of mousetrapped young Rana pipiens and Rana clamitans: Herpetologica, v. 17, p. 174-179.

Woodward, B.D., 1982, Tadpole competition in a desert anuran community: Oecologia, v. 54, p. 96100.

Woodward, B.D., 1983, Predator-prey interactions and breeding-pond use of temporary-pond species in a desert anuran community: Ecology, v. 64, p. 1549-1555.

Zampella, R.A., and Bunnell, J.F., 2000, The distribution of anurans in two river systems of a coastal plain watershed: Journal of Herpetology, v. 34, p. 210-221.

Zaranko, D.T., Griffiths, R.W., and Kaushik, N.K., 1997, Biomagnification of polychlorinated biphenyls through a riverine food web: Environmental Toxicology and Chemistry, v. 16, p. 14631471.

Zenisek, C.J., 1963, A study of the natural history and ecology of the leopard frog, Rana pipiens (Schreber): Ph.D. Thesis, Ohio State University, Columbus, 153 pp. 


\section{Tadpole Shrimp (Triops longicaudatus)}

\section{Introduction}

The tadpole shrimp (Triops longicaudatus), also called the longtail tadpole shrimp, American tadpole shrimp or rice tadpole shrimp, is a freshwater crustacean of the order Notostraca. It

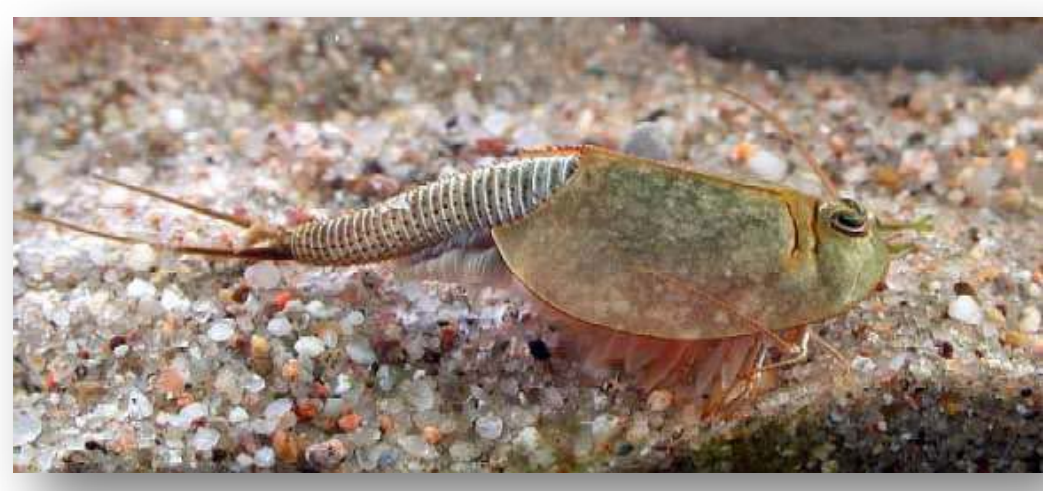

Tadpole Shrimp, courtesy of Dominik Tomaszewski. resembles a miniature horseshoe crab. It is characterized by an elongated, segmented body, flattened shield-like brownish carapace covering two thirds of the thorax and two long filaments on the abdomen. They are called tadpole shrimp because of their superficial resemblance to frog larvae (Golzari and others, 2009). Triops refers to its three eyes and longicaudatus refers to the elongated tail structures. The tadpole shrimp is found in freshwater ponds and pools, often in places where few higher forms of life can exist. Like its relative Triops cancriformis (horseshoe shrimp, endangered in Europe), the tadpole shrimp is considered a living fossil because its basic prehistoric morphology has changed little in the last 70 million years. The tadpole shrimp is widely distributed throughout western United States and its range is expanding eastward; it has recently been found in rice fields in the bootheel of Missouri (Tindall and others, 2009; Ridings and others, 2010).

A simple Google search on the Internet for "Triops longicaudatus" revealed 1,050,000 results and a Google Scholar search provided 579 results (accessed 11 July 2011). “Tadpole shrimp” revealed 107,000 results through Google and 983 results through Google Scholar (accessed 11 July 2011).

\section{Natural History}

The tadpole shrimp is in the crustacean class Branchiopoda, a morphologically diverse group of ecologically important, largely freshwater organisms that has a fossil record extending back to the Upper Cambrian (Walossek, 1993; Brendonck and others, 2008). Most large branchiopod species rely on seasonal wetlands, salt flats, and alkali pans, while other species occur in permanent playas, fishless alkali lakes, and salt lakes (Dumont and Megrea, 2002). These habitats are, for the most part, seasonal pools that are dry for a significant portion of the year, or several years (Dumont and Megrea, 2002). The tadpole shrimp are predominantly benthic and omnivorous, feeding on detritus and living or dead organisms (Martin, 1992). They are also known to feed on mosquito larvae (Maffi, 1962), amphibian tadpoles (Knoepffler, 1979), mayflies (Callibaetis californicus; Walton and others, 1991), and rice seedlings (Crossland, 1964).

Branchiopod crustaceans rely on banks of resting eggs (or "cysts") to bridge periods of drought or frost (Brendonck, 1996) and buffer against the effects of environmental variability. The eggs lay dormant in the substrate until the pool dries and refills during subsequent rains. In the temporally fluctuating environment of temporary aquatic habitats, usually only a portion of the dormant eggs, if any, hatch during each flooding period (Hildrew, 1985). This process can lead to the generation of an egg bank that can remain viable for decades or possibly centuries without rehydration (Belk, 1998), and can harbor potentially great genetic and species diversity (Ellner and Hairston, 1994). Many species of branchiopoda are distributed throughout their range as eggs, blown about as dust or transported by birds or insects (Pennak, 1989). In fact, on the Colorado Plateau, wind is suspected to be the primary dispersal 
mechanism for large branchiopod cysts (Graham and Wirth, 2008). Other modes of cyst dispersal include transport in or upon larger animals (for example, ducks; Proctor, 1964) or attached to dry pieces of wind-blown vegetation.

The eggs of tadpole shrimps are small, light in weight because of their dry alveolar shells, and sticky when laid (Longhurst, 1955). A release from diapause is triggered by changes in temperature, daylight length, dissolved oxygen, or salinity (Scott and Grigarick, 1979; Pearse and others, 1987; Su and Mulla, 2002a). Previous studies on the reproductive and sex ratios of the tadpole shrimp have revealed the occurrence of hermaphrodites along with gonochoric individuals (individual containing only male or only female reproductive organs). Grigarick and others (1961) reported that tadpole shrimp in the rice fields of California exhibited gonochoric and hermaphroditic reproduction. Sex ratios in many populations of tadpole shrimp are skewed towards females (Garcia-Valzco and others, 2009). Tadpole shrimp do not feed until they develop into the juvenile stage when they initially feed on detritus and later become omnivorous. Individuals reach sexual and trophic maturity in as little as six days (Harings, 2008).

Sassaman and others (1997) used electrophoresis to analyze 31 populations of tadpole shrimp at sites ranging from California to Kansas and found that the species is actually a mixture of at least two reproductively isolated species. In the central United States, including the SLV in Colorado, the predominant species is Triops longicaudatus, which is found typically in ephemeral prairie pools. In the southwestern United States, the predominant species is Triops newberryi (Packard), which characteristically inhabits large playa pools. The two species coexist occasionally and in sympatric situations they are reproductively isolated from each other. The two species are genetically distinct at a level greater than is typical of conspecific populations.

It is not uncommon for tadpole shrimp to co-occur in the same ephemeral pond with members of several other branchiopod orders such as Anostraca and Conchostraca (Graham, 1995). Branchiopod communities in ephemeral pools with at least one species in each of the three orders (Notostraca, Anostraca, and Conchostraca) have been reported in a number of studies (for example, Horne, 1971; O’Brian and DeNoyelles, 1972; McKay and others, 1990). Tadpole shrimp have also been shown to structure macroinvertebrate communities in playa lake microcosms (Yee and others, 2005). Yee and others (2005) found that removing tadpole shrimp shortly after hatching reduced the abundances of many other taxa, and decreased subsequent taxonomic richness and diversity. Direct effects of tadpole shrimp removal include the reduction of prey species abundance, which in turn may alter biotic interactions among other taxa. Indirect effects include physical modification of the environment during foraging through surface sediments. Walton (2001) also found that the successional pattern and size structure of aquatic insect communities differed among ponds in the California desert (Coachella Valley) depending on the presence of the tadpole shrimp, Triops newberryi. The densities of aquatic insects in Coachella Valley ponds were nearly an order of magnitude lower when Triops was present.

Both developing and adult tadpole shrimp can survive long periods in hypoxic situations that alter Hemoglobin (Hb) concentration (Scholnick and Snyder, 1996; Guadagnoli and others, 2005), which affords the animal an increase in oxygen-carrying capacity. Tadpole shrimp also have been found to reduce oxygen demand to match oxygen supply (Harper and Reiber, 2006).

A major selective force on the biota of ephemeral environments is the limited time individuals have to grow to reproductive age before the environment becomes inhospitable (Davis and Madison, 2000). The ability of the tadpole shrimp to develop and grow quickly is crucial to its success. Much of the research on tadpole shrimp has focused on the desiccation-resistant eggs, whereas almost all research on the behavior of the species has focused on the adult form (Davis and Madison, 2000). Young tadpole shrimp typically inhabit the surface areas of ephemeral pools, whereas older individuals 
are usually benthic. Davis and Madison (2000) postulated several reasons why it is adaptive for young tadpole shrimp to be surface water inhabitants. First, the higher oxygen concentration in surface water would promote rapid growth and earlier maturation of the young. Scholnick (1995) found that individuals raised in hyperoxic conditions grew faster and produced eggs four days earlier than those raised in hypoxic conditions. Second, surface water is warmer, and therefore could accelerate development of young tadpole shrimp. Oxygen consumption rates are three times more sensitive to temperature in immature tadpole shrimp than in older individuals, whose oxygen consumption rates remain relatively constant with changes in temperature (Hillyard and Vinegar, 1972). As a result, young tadpole shrimp ( $<5$ days) raised at higher temperatures grow faster than those raised at lower temperatures, a pattern that is not seen in individuals older than five days. Individuals raised at higher temperatures produced eggs a day earlier than those raised at lower temperatures (Scholnick, 1995). Additionally, there is some evidence that older individuals grow faster in colder temperatures (Scott and Grigarick, 1978). Diet differences between young and adult tadpole shrimp could also lead to vertical habitat segregation. Adult tadpole shrimp are primarily benthic feeders (Kaestner, 1970), but young tadpole shrimp do not have the appendages needed for efficient benthic feeding. These differences in body morphology make it possible for older individuals to spend more time lower in the water column, which eases selective pressures on younger individuals. Predation pressure on young and old tadpole shrimp may also favor segregation of habitat. Larger and older tadpole shrimp are depredated by birds (Takahashi, 1977), which are likely to attack individuals in surface waters. In contrast, young tadpole shrimp, are too small for avian predators and can benefit from the higher oxygen and warmer temperatures at the surface with less risk from avian predation. Young tadpole shrimp are also extremely vulnerable to cannibalism by adults (Scott and Grigarick, 1978; Murataw, 1995) making it particularly advantageous for young tadpole shrimp to swim higher in the water column, away from benthic adults.

Factors affecting survival and growth of tadpole shrimp are water temperature (Fry and Mulla, 1996; Hillyard and Vinegar, 1972) and breeding density (Takahashi and Gohda, 1981; Weeks, 1990; Weeks and Sassaman, 1990). Unfavorable temperatures can suppress hatching of eggs (Hall, 1961; Moore, 1967; Horne, 1971). For instance, in Wyoming the seasonal appearance of seven different branchiopods was thermally dependent, whereas survival of adult shrimp was unaffected by wide fluctuations in temperature (Horne, 1967). A similar pattern was also found in Texas ephemeral ponds (Horne, 1971).

Succession of macroinvertebrates in playas of the Southern High Plains of western Texas was studied by Moorhead and others (1998). They found that the playas were all dry within 90 days. Species richness and diversity increased significantly over time; some taxa increased in abundance (especially insects), whereas others decreased (most crustaceans). Trophic structure also changed over time, with a significant reduction in detritivores and filter feeders as time progressed coincident with an increase in the abundance of predators (Moorhead and others, 1998). These results suggested a rapid development of macroinvertebrate assemblage in playas, beginning with an early dominance of crustacean detritivores and filter-feeders (for example, tadpole shrimp), followed by later dominance of herbivorous and predaceous insects.

\section{Threats}

Worldwide changes in land use, brought about mainly by agriculture and urbanization, have led to a global loss and deterioration of temporary pools. Large branchiopods are used in the United States for assessment of ephemeral wetland habitat functions and values (Rogers, 1998), and five species in the United States are currently listed as threatened or endangered in California and Oregon. 
The application of insecticides can be a threat to tadpole shrimp, and various synthetic pyrethroids and organophosporous pesticides have been used to control tadpole shrimp, especially in rice fields of southern California (Walton and others, 1990b). Copper sulfate has also been used to control tadpole shrimp populations in rice fields (Grigarick and others, 1985).

Salinity has a negative effect on the tadpole shrimp (Horne, 1967). Horne (1967) conducted field and laboratory experiments on tadpole shrimp by exposing them to different concentrations of salinity. Definite decreases occurred in percentage hatch of eggs subjected to osmotic concentrations greater than 22 mmoles/liter (999 ppm), and eggs failed to hatch during the 2-week incubation period in higher salinities (66 mmole/liter). After having been exposed for 2 weeks to the latter solution, tadpole shrimp eggs hatched if the environment was subsequently diluted. Tadpole shrimp are also less resistant to increasing salinities if the magnesium concentration is high (Horne, 1968).

The introduction of exotic fishes to naturally fishless waters is often associated with declines of species native to those waters. Mosquitofish (Gambusia affinis) have been introduced to waters worldwide for mosquito control. Taxa negatively affected by mosquitofish potentially include tadpole shrimp. Leyse and others (2003) tested the effects of mosquitofish on a fairy shrimp (Linderiella occidentalis) in experimental ponds that included a community of native aquatic invertebrates. Survival of fairy shrimp was significantly reduced in ponds with mosquitofish, with only 16.9 percent survival in ponds with mosquitofish and 64 percent survival in control ponds. Fish presence also reduced the abundance and biomass of other invertebrates. They concluded that introduction of mosquitofish into naturally fishless wetlands may lead to lower diversity of highly specialized aquatic fauna.

Climate change has the potential to threaten tadpole shrimp populations. The species most directly impacted by changes in climate may be the obligate aquatic organisms with life histories that are tightly coupled to hydrologic conditions. Vernal pool branchiopods, such as the tadpole shrimp, fit this definition (Pyke, 2005). Pyke (2005) assessed the potential impacts of climate change on vernal pool ecosystems and endemic branchiopods in the Central Valley of California. He examined the potential changes in hydrological regimes for vernal pools from various climate change scenarios. Current climate change predictions for terrestrial areas in the Northern Hemisphere indicate higher maximum and minimum near-surface air temperatures, decreasing diurnal temperature ranges, more intense precipitation events, increased summer continental drying, and an increased risk of drought (Houghton and others, 2001; Stott and others, 2001; Johns and others, 2003). Pyke (2005) predicted that the warmer, higher-precipitation conditions would result in a net shift toward longer, more frequent periods of inundations for vernal pools in the Central Valley. An increased duration of inundation has the potential to yield increases in both the diversity and abundance of aquatic predators (Schneider, 1997). Several authors have noted negative correlations between the abundance of predators and branchiopods (Sublette and Sublette, 1967; Dodson, 1987; Loring and others, 1988). Increased predation could be mitigated by changes in the relative frequency of reproductively suitable, but more ephemeral, vernal pools (Pyke, 2005).

\section{Management}

Literature found related to management and tadpole shrimp mostly focused on its role as a pest in ricefields and its capabilities as a mosquito-control agent. No studies that examined the effects of mowing, haying, or burning were found. The following is a selection of citations found related to management of tadpole shrimp:

- The tadpole shrimp is a pest in rice fields in at least seven countries on four continents (Grigarick and others, 1961; Grigarick, 1984). Alternatively, these shrimp have been used to control weeds in rice fields in Japan (Takahashi, 1977; 1994), and also have been proposed as a 
biological control agent of mosquitoes (Tietze and Mulla, 1991; Fry and others, 1994). In the United States, tadpole shrimp are sporadic pests in rice fields, mainly in California (Grigarick and others, 1961; Rosenberg, 1947). Recently, tadpole shrimp were found in ricefields in Missouri, representing a range expansion into the northern Mississippi River alluvial plains (Tindall and others, 2009). Damage occurs when the shrimp feed upon and uproot young seedlings and the characteristic increase in suspended silt as a result of their burrowing action decreases the photosynthetic capacity of the rice plant (Rosenberg, 1947). Tadpole shrimp can be controlled after hatch by chemical applications (Grigarick and others, 1961). In contrast, tadpole shrimp are considered beneficial to rice fields in Japan, where cultural practices differ from those in the United States (Fry and Mulla, 1992). In Japan, rice seedlings transported from nurseries to fields have reached a size at which shrimp are no long able to dislodge or harm them. This rice culture practice promotes the use of tadpole shrimp for weed control because they feed upon and uproot young weed plants (Takahashi, 1977).

- Tadpole shrimp have been noted to devour mosquito larvae (Mail, 1934; Maffi, 1962; Scott and Grigarick, 1979; Tietze and Mulla, 1989), which led to the supposition that they could be used in mosquito control efforts. In recent studies, Tietze and Mulla (1989; 1990; 1991) have demonstrated reduction in mosquito populations by tadpole shrimp through active predation. Tietze and Mulla (1991) also reported that the surface swimming behavior of tadpole shrimp interferes with the oviposition activity of gravid mosquitoes on the water surface. Furthermore, tadpole shrimp were demonstrated to have the potential to enhance the efficacy of microbial control agents such as Bacillus thuringiensis spp. israelensis (Bti) for mosquito control as their digging activity and vertical foraging process in the water column facilitate the availability of Bti toxin particles to mosquito larval feeding (Fry and others, 1994; Fry-O’Brien and Mulla, 1996; Kumar and Hwant, 2006). However, when another version of larvicidal oil was used, Bacillus sphaericus Neide and Golden Bear-1111®, it caused 100 percent mortality of tadpole shrimp within 48 hours after treatment in the laboratory even at very low dosages (Su and Mulla, 2005).

- The effectiveness of tadpole shrimp for controlling mosquitoes depends on the species of mosquito and local habitat features. For example, Harings (2008) conducted experiments with tadpole shrimp and the mosquito, Culex pipiens, and concluded that tadpole shrimp would probably be ineffective control agents of this particular species' larvae, especially when algae are highly abundant.

- To develop and promote tadpole shrimp as predators for controlling mosquitoes, eggs and mature adult shrimp were introduced in 2000 in a date garden in the Coachella Valley, southern California that was devoid of preexisting tadpole shrimp (Su and Mulla, 2002b). One year after the introduction of the shrimp eggs and adults, it was found that the plots with relatively high numbers of tadpole shrimp had reduced numbers of mosquitoes (Psorophora columbiae) by 73 to 99 percent.

- Pond or field flooding regimens may directly affect hatch rates of tadpole shrimp eggs by providing soil conditions either unsuitable for or amenable to hatching (Fry and Mulla, 1992). As in other floodwater organisms, desiccation of eggs is an integral part of tadpole shrimp biology in natural situations. Qualitative observations suggest that their eggs do not readily hatch on flooding when the soil or substrate containing eggs is moist (Igarishi, 1970). Therefore, in intermittent flooding systems with controlled irrigation, soil moisture content may be managed by manipulation of flood intervals. Potentially, control of soil moisture content may be used alternatively either to maximize shrimp numbers or to eliminate their hatch altogether (Fry and Mulla, 1992). Fry and Mulla (1992) examined the relationship between drying (moisture 
content) of soil after flooding and tadpole shrimp hatches at two locations in southern California. They found that soil moisture content is indeed a very important factor influencing the hatching rates of tadpole shrimp. Decreasing soil moisture may provide a physiological cue to tadpole shrimp eggs that allows hatching to occur at the next flooding, provided embryonic development is complete. In the field, no hatch was apparent from soils measuring $>24.3$ percent moisture. They suggested that if large populations of tadpole shrimp are desired as either mosquito or weed control agents, flooding of the habitat containing tadpole shrimp eggs can begin as soon as the soil surface is dry. The only other apparent requirement is that the water temperature exceed a lower thermal limit. For tadpole shrimp collected from the Central Valley of California, this lower limit is $14^{\circ} \mathrm{C}$ (Scott and Grigarick, 1979).

- Irrigation practices may have a large effect on the population of tadpole shrimp where they exist in agricultural systems (Fry and Mulla, 1992). In flood-irrigated fields or other areas where water supplies can be manipulated, tadpole shrimp populations can be manipulated as well. Fry and Mulla (1992) suggested that this type of water management could ultimately be used to increase shrimp populations where they are beneficial organisms playing a role as mosquito or weed control agents. Similarly, the control of flooding regiments could also be used to inhibit hatching of tadpole shrimp where they are considered pests (for example, rice fields in California). Water management would reduce the use of pesticides necessary to control the shrimp.

- Hamasaki (1999) showed that tadpole shrimp did not occur in rice paddy fields employing organic farming methods, although they occurred in conventionally farmed fields. Organic fields had lower water $\mathrm{pH}$ (high acidification) than conventional fields and he suggested that water $\mathrm{pH}$ could be responsible for this difference (Hamasaki and Ohbayashi, 2000). Hamasaki and Ohbayashi (2000) examined survival of tadpole shrimp under different $\mathrm{pH}$ conditions and the effect of rectifying the acidity of organic farming paddy soil using $\mathrm{Ca}(\mathrm{OH})_{2}$. Treatments with $\mathrm{pH}$ of 4.4 to 5.3 killed all larvae within 12 hours. At treatments with $\mathrm{pH} 5.9$ to 6.6, the survival rate of the larvae until 24 hours was more than 50 percent, and the rate increased with increasing $\mathrm{pH}$. Treatment of soil with $\mathrm{Ca}(\mathrm{OH})_{2}$ increased the $\mathrm{pH}$ to 6.7 and increased survival to 60 percent. They concluded that the boundary of suitable and unsuitable water $\mathrm{pH}$ for larval survival was between 5.7 and 5.9, and the larvae can grow to ovipositional stage by treating soil acidity (Hamasaki and Ohbayashi, 2000).

- Selected rice fields on the Sacramento National Wildlife Refuge Complex were aerially sprayed one time during May or June 1982 with either ethyl (0.11 kg AI/ha) or methyl (0.84 kg AI/ha) parathion for control of tadpole shrimp (Custer and others, 2008). No sick or dead vertebrate wildlife were found in or adjacent to the treated rice fields after spraying. Specimens of the following birds and mammals were assayed for brain cholinesterase (CheE) activity to determine exposure to either form of parathion: house mouse (Mus musculus); black-tailed jackrabbit (Lepus californicus); mallard (Anas platyrhynchos); ring-necked pheasant (Phasianus colchicus); American coot (Fulica americana); and red-winged blackbird (Agelaius phoeniceus). Both mice and pheasants from methyl parathion-treated fields had overall mean ChE activities that were significantly $(\mathrm{P}<.05)$ inhibited compared with controls, and 7, 40, 54, and 57 percent of individual blackbirds, pheasants, mice, and coots, respectively, had inhibited brain ChE activities (for example, less than -2 SD of control mean)(Custer and others, 1985).

- Colonization and succession of mosquitoes and macroinvertebrate predators such as tadpole shrimp were studied in 30- $\mathrm{m}^{2}$ ponds (mesocosms) during summer and fall 1987 (Walton and others, 1990a). Larval abundance of $C x$. tarsalis Coquillett was lower during the hot, summer 
months than during the fall. In all studies, larval populations declined markedly 2-3 wk after habitat flooding. Although predator abundances differed in these studies, sometimes by an order of magnitude, the common predators colonized mesocosms in the following order: tadpole shrimp, hydrophilid beetle larvae, dytiscid beetle larvae, mesoveliids, dragonfly and damselfly naiads, and notonectids. The similarity of the colonization phenologies probably resulted from the vagility of the adult insects and species-specific developmental rates. Stepwise multiple regression was used to identify factors potentially affecting larval mosquito populations. For most studies, coleopteran larvae were related inversely to per capita change in the entire larval population and the third- and fourth-instar subpopulation (for example, large coleopteran larval populations were associated with large declines in the $C x$. tarsalis larval population). Maximum water temperatures and pond age (days after flooding) also were identified as significant factors affecting larval abundance and per capita change of mosquitoes. Potentially lethal water temperatures $\left(\geq 35^{\circ} \mathrm{C}\right)$ occurred during the summer; however, the declines in larval abundance of $C x$. tarsalis were not restricted to (or obviously associated with) periods of high water temperature. Study results indicated that predation by coleopteran larvae and factor(s) associated with pond age, such as mosquito ovipositional preferences, significantly affected $C x$. tarsalis larval populations (Walton and others, 1990a).

- Methyl farnesoate (MF), shown to inhibit adult metamorphosis in several crustaceans, was shown to be a native, juvenilizing factor that delays adult metamorphosis of tadpole shrimp (Nelson, 2006). Juvenile hormone III, possessing a structure similar to that of MF, has been established as a hormone that regulates metamorphosis in insects. Methyl farnesoate may have an analogous role in crustaceans. The effect of MF on oocyte production, performed exclusively by adults, and MF metabolism were assayed. Treatment with MF reduced oocyte production in individuals treated during the larval/juvenile stages, suggesting retention of the juvenile morphotype and inhibition of gonad development. When administered to adults, no reduction in oocyte production was observed. MF-synthesis by the enzyme farnesoic acid O-methyl transferase was found in the several tissues. Nelson (2000) concluded that MF is synthesized by the tadpole shrimp and regulates adult metamorphosis; thus it is a native, juvenilizing agent in tadpole shrimp.

\section{Research Priorities}

No suggested list of research priorities or information needs for tadpole shrimp were found during this literature review.

\section{Bibliography}

Angeler, D.G., Viedma, O. and Sanchez-Carrillo, and Alvarez-Cobelas, M., 2008, Conservation issues of temporary wetland Branchiopoda (Anostraca, Notostraca: Crustacea) in a semiarid agricultural landscape: what spatial scales are relevant?: Biological Conservation, v. 141, p. 1224-1234.

Belk, D., 1998, Global status and trends in ephemeral pool invertebrate conservation: implications for California fairy shrimp: Pp. 147-150 in Whitham, C.W., Bauder, E.T., Belk, D., Ferren, W.R., Jr., Ferren, W.R., Jr., and Ornduff, R., eds., Ecology, Conservation, and Management of Vernal Pool Ecosystems - Proceedings from a 1996 Conference, California Native Plant Society, Sacramento, California.

Brendonck, L., 1996, Diapause, quiescence, hatching requirements: what we can learn from large freshwater branchiopods (Crustacea: Branchiopoda: Anostraca, Notostraca, Conchostraca): Hydrobiologia, v. 320, p. 85-97. 
Brendonck, L., Rogers, D.C., Olesen, J., Weeks, S., and Hoeh, W.R., 2008, Global diversity of large branchiopods (Crustacea: Branchiopoda) in freshwater: Hydrobiologia, v. 595, p. 167-176.

Croel, R.C., and Kneitel, J.M., 2011, Ecosystem-level effects of bioperturbation by the tadpole shrimp Lepidurus packardi in temporary pond mesocosms: Hydrobiologia, v. 665, p. 169-181.

Crossland, N.O., 1964, New agricultural pest in Africa: Nature, v. 202, p. 342-343.

Custer, T.W., Hill, E.F., and Ohlendorf, H.M., 1985, Effects on wildlife of ethyl and methyl parathion applied to California rice fields: California Fish and Game, v. 71, p. 220-224.

Davis, J.M., and Madison, D., 2000, The ontogeny of light-dark response in Triops longicaudatus as a response to changing selective pressures: Crustaceana, v. 73, p. 283-288.

Debrey, L.D., Schell, S.P., and Lockwood, J.A., 1991, Sympatric occurrence of 3 species of Eubranchiopoda in a vernal prairie pond in southeastern Wyoming: American Midland Naturalist, v. 126, p. 399-400.

Dodson, S.I., 1987, Animal assemblages in temporary desert rock pools: aspects of the ecology of Dasyhelea sublettei (Diptera: Ceratopogonidae): Journal of the North American Benthological Society, v. 6, p. 75-71.

Dumont, H.J., and Negrea, S., 2002, Introduction to the Class Branchiopoda: Guides to the Microinvertebrates of the Continental Waters of the World, Backhuys, Leiden.

Echaniz, S.A., and Vignatti, A.M., 2010, Diversity and changes in the horizontal distribution of crustaceans and rotifers in an episodic wetland of the central region of Argentina: Biota Neotropica, v. 10, p. 133-141.

Ellner, S., and Hariston, N.G., Jr., 1994, Role of overlapping generations in maintaining genetic variation in a fluctuating environment: American Naturalist, v. 143, p. 403-417.

Fjellheim, A., Tysse, A., and Bjerknes, V., 2001, Reappearance of highly acid-sensitive invertebrates after liming of an alpine lake ecosystem: Water, Air, and Soil Pollution, v. 130, p. 1391-1396.

Fox, R., Triops longicaudatus, Tadpole shrimp: Invertebrate Anatomy OnLine, Lander University. Online at http://webs.lander.edu/rsfox/invertebrates/triops.html. Accessed 11 July 2011.

Fry, L.L., and Mulla, M.S., 1992, Effect of drying period and soil-moisture on egg hatch of the tadpole shrimp (Notostraca, Triopsidae): Journal of Medical Entomology, v. 85, p. 65-69.

Fry, L.L., and Mulla, M.S., 1996, Optimal conditions for rearing the tadpole shrimp, Triops longicaudatus (Notostraca: Triopsidae), a biological control agent against mosquitoes: Journal of the American Mosquito Control Association, v. 12, p. 446-453.

Fry, L.L., Mulla, M.S., and Adams, C.W., 1994, Field introductions and establishment of the tadpole shrimp, Triops longicaudatus (Notostraca: Triopsidae), a biological control agent of mosquitos: Biological Control, v. 4, p. 113-124.

Fry-O’Brien, L.L., and Mulla, M.S., 1996, Effect of tadpole shrimp, Triops longicaudatus, (Notostraca: Triopsidae), on the efficacy of the microbial control agent Bacillus thuringiensis var Israelensis in experimental microcosms: Journal of the American Mosquito Control Association, v. 12, p. 33-38.

Garcia-Velazco, H., Obregon-Barboza, H., Rodriguez-Jaramillo, C., and Maeda-Martinez, A.M., 2009, Reproduction of the tadpole shrimp Triops (Notostraca) in Mexican waters: Current Science, v. 96, p. 91-97.

Golzari, A., Khodabandeh, S., and Seyfabadi, J., 2009, Some biological characteristics of tadpole shrimp, Triops cancriformis, from seasonal pools of West Azarbaijan (Iran): J. Agric. Sci. Technol., v. 22, p. 81-90.

Graham, T.B., 1995, Sympatric occurrence of Eubranchiopoda in ephemeral pools: a comment: American Midland Naturalist, v. 133, p. 371-372. 
Graham, T.B., and Wirth, D., 2008, Dispersal of large branchiopod cysts: potential movement by wind from potholes on the Colorado Plateau: Hydrobiologia, v. 600, p. 17-27.

Grigarick, A.A., 1984, General problems with rice invertebrate pests and their control in the United States: Protection Ecology, v. 7, p. 105-114.

Grigarick, A.A., Lange, W.H., and Finfrock, D.C., 1961, Control of the tadpole shrimp, Triops longicaudatus, in California rice fields: Journal of Economic Entomology, v. 54, p. 36-40.

Guadagnoli, J.A., Braun, A.A., Roberts, S.P., and Reiber, C.L., 2005, Environmental hypoxia influences hemoglobin subunit composition in the branchiopod crustacean Triops longicaudatus: Journal of Experimental Biology, v. 208, p. 3543-3551.

Hall, R.E., 1961, On some aspects of the natural occurrence of Chirocephalus diaphanous Prevost: Hydrobiologia, v. 17, p. 205-217.

Hamasaki, K., 1999, Occurrence of American tadpole shrimp, Triops longicaudatus (LeConte), in paddy fields cultivated under conventional and organic farming methods: Japanese Journal of Applied Entomology and Zoology, v. 43, p. 35-40.

Hamasaki, K., and Ohbayashi, N., 2000, Effect of water $\mathrm{pH}$ on the survival rate of larvae of the American tadpole shrimp, Triops longicaudatus (LeConte) (Notostraca: Triopsidae): Applied Entomology and Zoology, v. 35, p. 225-230.

Harings, N.M., 2008, Behavioral and morphological ontogeny of the tadpole shrimp Triops longicaudatus (Leconte) (Notostraca: Triopsidae): Unpublished M.S. Thesis, Eastern New Mexico University, Portales, New Mexico.

Harper, S.L., and Reiber, C.L., 2006, Metabolic, respiratory and cardiovascular responses to acute and chronic hypoxic exposure in tadpole shrimp Triops longicaudatus: Journal of Experimental Biology, v. 209, p. 1639-1650.

Hazelwood, D.H., and Hazelwood, S.E., 1985, The effect of temperature on oxygen consumption in four species of freshwater fairy shrimp (Crustacea: Anostraca): Freshwater Invertebrate Biology, v. 4, p. 133-137.

Hengherr, S., Heyer, A.G., Brummer, F., and Schill, R.O., 2011, Trehalose and vitreous states: desiccation tolerance of dormant stages of the crustaceans Triops and Daphnia: Physiological and Biochemical Zoology, v. 84, p. 147-153.

Hildrew, A.G., 1985, A quantitative study of the life history of a fairy shrimp (Branchiopoda: Anostraca) in relation to the temporary nature of its habitat, a Kenyan rainpool: Journal of Animal Ecology, v. 54, p. 99-110.

Hillyard, S.D., and Vinegar, A., 1972, Respiration and thermal tolerance of the phyllopod crustacean Triops longicaudatus and Thamnocephalus platyurus inhabiting desert ephemeral ponds: Physiological Zoology, v. 45, p. 189-196.

Horne, F.R., 1966, Some aspects of ionic regulation in the tadpole shrimp Triops longicaudatus: Comparative Biochemistry and Physiology, v. 19, p. 313-316.

Horne, F., 1971, Some effects of temperature and oxygen concentration on phyllopod ecology: Ecology, v. 52, p. 343-347.

Hossack, B.R., Newell, R.L., and Rogers, D.C., 2010, Branchiopods (Anostraca, Notostraca) from protected areas of western Montana: Northwest Science, v. 84, p. 52-59.

Houghton, J.T., Ding, Y., Griggs, D.J., Noguer, M., Van der Linden, P.J., and Xiaosu, C., 2001, Climate change 2001: the scientific basis. Contribution of Working Group I to the Third Assessment Report of the Intergovernmental Panel on Climate Change (IPCC), Cambridge, Cambridge University Press.

Igarishi, K., 1970, Ecological studies on Triops longicaudatus (Notostraca) inhabiting Shonaie District, Japan: Journal of the Yamagata Agricultural and Forestry Society, v. 23, p. 33-39. 
Jocque, M., Graham, T., and Brendwonck, L., 2007, Local structuring factors of invertebrate communities in ephemeral freshwater rock pools and the influence of more permanent water bodies in the region: Hydrobiologia, v. 592, p. 271-280.

Johns, T.C., Gregory, J.M., Ingram, W.J., Johnson, C.E., Jones, A., Lowe, J.A., Mitchell, J.F.B., Roberts, D.L., Sexton, D.M.H., and Stevenson, D.S., 2003, Anthropogenic climate change for 1860 to 2100 simulated with the HadCM3 model under updated emissions scenarios: Climate Dynamics, v. 20, p. 583-612.

Kaestner, A., 1970, Invertebrate zoology, v. 3, p. 95-100.

Knoepffler, L.P., 1979, Triops cancriformis (Bosc.) crustace phyllopodes predatur de tetards et de jeunes amphibiens: Vie et Milieu (C), v. 28-29, p. 117-121.

Kumar, R., and Hwang, J., 2006, Larvicidal efficiency of aquatic predators: a perspective for mosquito biocontrol: Zoological Studies, v. 45, p. 447-466.

Leyse, K.E., Lawler, S.P., and Strange, T., 2004, Effects of an alien fish, Gambusia affinis, on an endemic California fairy shrimp, Linderiella occidentalis: implications for conservation of diversity in fishless waters: Biological Conservation, v. 118, p. 57-65.

Longhurst, A.R., 1955, Evolution of the Notostraca: Evolution, v. 9, p. 84-86.

Loring, S.J., MacKay, W.P., and Whitford, W.G., 1988, Ecology of small desert playas: Pp. 89-113 in Thames, J.L., and Ziebell, C.D., eds., Small water impoundments in semi-arid regions, University of New Mexico Press, Albuquerque, New Mexico.

Macdonald, K.S., III, Sallenave, R., and Cowley, D.E., 2011, Morphologic and genetic variation in Triops (Branchiopoda: Notostraca) from ephemeral waters of the Chihuahuan Desert of North America: Journal of Crustacean Biology, v. 31, p. 468-484.

Mackay, W.P., Loring, S.J., Frost, T.M., and Whitford, W.G., 1990, Population dynamics of a playa community in the Chihuahuan desert: Southwestern Naturalist, v. 35, p. 393-402.

Maffi, M., 1962, Triops granaries (Lucas) (Crustacea) as a natural enemy of mosquito larvae: Nature, v. 195, p. 722.

Mail, G.A., 1934, The mosquitoes of Montana: Montana Agricultural and Experimental Station Bulletin, v. 288.

Mantovani, B., Cesari, M., and Scanabissi, F., 2003, Molecular taxonomy and phylogeny of the "living fossil” lineages Triops and Lepidurus (Branchiopoda: Notostraca): Zoologica Scripta, v. 33, p. 367374.

Martin, J.W., 1992, Branchiopoda: Pp. 25-224 in Harrison, F.W., and Humes, A.G., eds., Microscopic anatomy of invertebrates, Crustacea, Vol. 9, Wiley-Liss, New York, New York.

Mogi, M., 2007, Insects and other invertebrate predators: Journal of the American Mosquito Control Association, v. 23, p. 93-109.

Moore, W.G., 1967, Factors affecting egg-hatching in Streptocephalus seali (Branchiopoda, Crustacea): Proceedings of the Symposium on Crustacea (Marine Biological Association of India), Part II, p. 724735.

Murataw, V.M., 1995, Cannibalism in Triops cancriformis: Vyestsi Akademii Ahrarnykh Navuk Byelarusi, v. 2, p. 91-93.

Murugan, G., Maeda-Martinez, A.M., Obregon-Barboza, H., and Hernandez-Saavedra, N.Y., 2002, Molecular characterization of the tadpole shrimp Triops (Branchiopoda: Notostraca) from the Baja California Peninsula, Mexico: new insights on species diversity and phylogeny of the genus: Hydrobiolgia, v. 486, p. 101-113.

Murphy, K.M., 1999, Temperature effects on the induction of diapause in tadpole shrimp, Triops longicaudatus, embryos: Unpublished M.A. Thesis, California State University, Fresno, California. 
Nelson, W., 2006, Juvenilizing effects of methyl farnesoate on reproduction and development in the Riceland tadpole shrimp, Triops longicaudatus: Unpublished M.S. Thesis, California State University, Fresno, California.

Obregon-Barboza, H., Maeda-Martinez, A.M., and Murugan, G., 2001, Reproduction, molting, and growth of two Mexican uniparental forms of the tadpole shrimp Triops (Branchiopoda: Notostraca) under a recirculating culture system: Hydrobiologia, v. 462, p. 173-184.

O’Brian, W.J., and DeNoyelles, F., Jr., 1972, Photosynthetically elevated pH as a factor in zooplankton mortality in nutrient enriched ponds: Ecology, v. 53, p. 605-613.

Olesen, J., 2007, Monophyly and phylogeny of Branchiopoda, with focus on morphology and homologies of branchiopod phyllopodous limbs: Journal of Crustacean Biology, v. 27, p. 165-183.

Pearse, V., Pearse, J., Buchsbaum, M., and Buchsbaum, R., 1987, Crustaceans: Pp. 481-528 in Living Invertebrates, The Boxwood Press, Pacific Grove, California.

Pennak, R.W., 1978, Freshwater invertebrates of the United States: John Wiley and Sons, New York, New York.

Pennak, R.W., 1989, Fresh-water invertebrates of the United States. Protozoa to Mollusca, $3^{\text {rd }}$ ed.: John Wiley and Sons, Inc., New York, New York.

Proctor, V.W., 1964, Viability of crustacean eggs recovered from ducks: Ecology, v. 45, p. 656-658.

Pyke, C.R., 2005, Assessing climate change impacts on vernal pool ecosystems and endemic branchiopods: Ecosystems, v. 8, p. 95-105.

Ridings, J.W., Schell, S.R., and Stearnes, W.T., 2010, The first record of American tadpole shrimp (Triops longicaudatus) in Illinois: Transactions of the Illinois State Academy of Science, v. 103, p. 49-50.

Rogers, D.C., 1998, Aquatic macroinvertebrate occurrences and population trends in constructed and natural vernal pools in Folsom, California: Pp. 224-235 in Whitham, C.W., Bauder, E.T., Belk, D., Ferren, W.R., Jr., Ferren, W.R., Jr., and Ornduff, R., eds., Ecology, Conservation, and Management of Vernal Pool Ecosystems - Proceedings from a 1996 Conference, California Native Platn Society, Sacramento, California.

Rosenberg, L.E., 1947, Apus as a pest in California rice fields: Pp. $42-48$ in Calif. Dept. Agric. Bull., v. 36.

Sassaman, C., Simovich, M., and Fugate, M., 1997, Reproductive isolation and genetic differentiation in North American species of Triops (Crustacea: Branchiopoda: Notostraca): Hydrobiologia, v. 359, p. 125-147.

Schneider, D., 1997, Predation and food web structure along a habitat duration gradient: Oecologia, v. 110, p. 567-575.

Scholnick, D.A., 1995, Sensitivity of metabolic-rate, growth, and fecundity of tadpole shrimp Triops longicaudatus to environmental variation: Biological Bulletin, v. 189, p. 22-28.

Scholnick, D.A., and Snyder, G.K., 1996, Response of the tadpole shrimp Triops longicaudatus to hypoxia: Crustaceana, v. 69, p. 937-948.

Scott, S.R., and Grigarick, A.A., 1979, Laboratory studies of factors affecting egg hatch of Triops longicaudatus (LeConte) (Notostraca: Triopsidae): Hydrobiologia, v. 63, p. 145-152.

Stott, P.A., Tett, S.F.B., Jones, G.S., Allen, M.R., Ingram, W.J., and Mitchell, J.F.B., 2001, Attribution of twentieth century temperature change to natural and anthropogenic causes: Climate Dynamics, v. 17, p. 1-21.

Su, T., and Mulla, M.S., 2002a, Factors affecting egg hatch of the tadpole shrimp Triops newberryi, a potential biological control agent of immature mosquitoes: Biological Control, v. 23, p. 18-26. 
Su, T., and Mulla, M.S., 2002b, Introduction and establishment of tadpole shrimp Triops newberryi (Notostraca: Triopsidae) in a date garden for biological control of mosquitoes in the Coachella Valley, southern California: Journal of Vector Ecology, v. 27, p. 138-148.

Su, T., and Mulla, M.S., 2002c, Spatial occurrence and hatch of field eggs of the tadpole shrimp Triops newberryi (Notostraca: Triopsidae), a potential biological control agent of immature mosquitoes: Journal of Vector Ecology, v. 27, p. 128-137.

Sublette, J.E., and Sublette, M.S., 1967, The limnology of playa lakes on the Llano Estacado, New Mexico and Texas: Southwestern Naturalist, v. 12, p. 369-406.

Takahashi, F., 1977, Pioneer life of the tadpole shrimps, Triops spp. (Notostraca: Triopsidae): Applied Journal of Entomology and Zoology, v. 12, p. 104-117.

Takahashi, F., 1994, Use of the tadpole shrimp (Triops spp.) as a biological agent to control paddy weeds in Japan: Pp. 128-138 in Bay-Peterson, J., ed., Integrated management of paddy and aquatic weeds in Asia, FFTC, Taipei.

Takahashi, F., and Gohda, M., 1981, The type of egg production curve with respect to population preservation: ecological studies of tadpole shrimps (Branchiopoda: Triopsidae) for the biological control of weeds in rice paddies: Verh. Internat. Verein. Limnol., v. 21, p. 1531-1540.

Tasch, P., 1969, New observations on the Notostracan Triops longicaudatus in natural and cultural situations: Transactions of the Kansas Academy of Science, v. 72, p. 323-329.

Taylor, C.M., Bryant, R.M., Jr., and Hartman, R.E., 1987, Eastward range extension of the tadpole shrimp, Triops longicaudatus (Leconte), in Oklahoma: Proceedings of the Oklahoma Academy of Sciences, v. 67, p. 75-76.

Terwilliger, N.B., and Ryan, M.C., 2006, Functional and phylogenetic analyses of phenoloxidases from brachyuran (Cancer magister) and branchiopod (Artemia fransiscana, Triops longicaudatus) crustaceans: Biological Bulletin, v. 210, p. 38-50.

Tietze, N.S., and Mulla, M.S., 1989, Prey size selection by Triops longicaudatus (Notostraca: Triopsidae) feeding on immature stages of Culex quinquefasciatus: Journal of the American Mosquito Control Association, v. 5, p. 392-396.

Tietze, N.S., and Mulla, M.S., 1990, Influence of tadpole shrimp, Triops longicaudatus (Notostraca: Triopsidae), stocking rate on Culex tarsalis development in experimental field microcosms: Journal of the American Mosquito Control Association, v. 6, p. 265-269.

Tietze, N.S., and Mulla, M.S., 1991, Biological control of Culex mosquitos (Diptera, Culicidae) by the tadpole shrimp, Triops longicaudatus (Notostraca, Triopsidae): Journal of Medical Entomology, v. 28, p. 24-31.

Tindall, K.V., Fothergill, K., Minson, W., and Ottis, B., 2009, A new pest of rice in Missouri: range expansion of Triops longicaudatus (Crustacea: Notostraca: Triopsidae) into the northern Mississippi river alluvial plains: Florida Entomologist, v. 92, p. 503-505.

Walossek, D., 1993, The Upper Cambrian Rehbachiella and the phylogeny of Branchiopoda and Crustacea: Fossils and Strata, v. 32, p. 1-202.

Walton, W.E., 2001, Effects of Triops newberryi (Notostraca: Triopsidae) on aquatic communities in ponds in the Colorado desert of southern California: Israel Journal of Zoology, v. 47, p. 491-511.

Walton, W.E., Darwazeh, H.A., Mulla, M.S., and Schreiber, E.T., 1990a, Impact of selected synthetic pyrethroids and organophosphorous pesticides on the tadpole shrimp, Triops longicaudatus (LeConte)(Notostraca: Triopsidae): Bulletin of Environmental Contamination and Toxicology, v. 45, p. 62-68. 
Walton, W.E., Tietze, N.S., and Mulla, M.S., 1990b, Ecology of Culex tarsalis (Diptera: Culicidae): factors influencing larval abundance in mesocosms in southern California: Journal of Medical Anthropology, v. 27, p. 57-67.

Walton, W.E., Tietze, N.S., and Mulla, M.S., 1991, Consequences of tadpole shrimp predation on mayflies in some California ponds: Freshwater Biology, v. 25, p. 143-154.

Weeks, S.C., 1990, Life-history variation under varying degrees of intraspecific competition in the tadpole shrimp Triops longicaudatus (LeConte): Journal of Crustacean Biology, v. 10, p. 498-503.

Weeks, S.C., and Sassaman, C., 1990, Competition in phenotypically variable and uniform populations of tadpole shrimp Triops longicaudatus (Notostraca: Triopsidae): Oecologia, v. 82, p. 552-5559.

Williams, T.A., and Muller, G.B., 1996, Limb development in a primitive crustacean, Triops longicaudatus: subdivision of the early limb bud gives rise to multibranched limbs: Dev Genes Evol, v. 206, p. 161-168.

Wooten, D., Triops longicaudatus: Zooplankton of the Great Lakes, Central Michigan University. Online at http://www.cst.cmich.edu/users/mcnau1as/zooplankton\%20web/Triops/Triops.html. Accessed 11 July 2011.

Yee, S.H., Willig, M.R., and Moorhead, D.L., 2005, Tadpole shrimp structure macroinvertebrate communities in playa lake microcosms: Hydrobiologia, v. 541, p. 139-148. 


\section{Summary}

Table 1. A summary of general and specific (when reported in the literature) habitat requirements for the 10 focal species in the Alamosa / Monte Vista / Baca National Wildlife Refuge Complex, Colorado. This table includes the species common name, the size of wetland or area, general habitats, nesting/breeding habitats, and foraging habitats. Text in this table can be found in the individual species accounts with appropriate citations.

\begin{tabular}{llll}
\hline $\begin{array}{l}\text { Species } \\
\text { (common name) }\end{array}$ & Size of wetland or area & General habitats & Nesting/Breeding habitats \\
\hline
\end{tabular}

- 6-19.3 ha;

- Daub (1993) sampled wetlands ranging from $<1$ to 19.3

American

Avocet

concluded that ha, and the avocet is an area-dependent species.

- $\quad>8$ ha (Prescott and others, 1995).
- Seasonal wetlands and habitats dominated by Baltic • Found in tilled, alkali, ephemeral, rush (Juncus balticus), sedges (Carex spp.), and grasses $<40 \mathrm{~cm}$ tall over semipermanent wetlands, habitats dominated by cattail (Typha spp.) and softstem bulrush (Scirpus validus) $>40 \mathrm{~cm}$ tall, saltgrass habitats, or upland shrub habitats;

- Use exposed, sparsely vegetated salt flats, sandbars, peninsulas, mudflats, or islands adjacent to shallow ( $<1$ m deep) water, conditions that occur in wetlands, lakes, fallow and flooded fields, or impoundments.

semipermanent, and permanent wetlands, and in impoundments, sewage lagoons, and evaporation ponds;

- Unvegetated ground or in areas with short, sparse vegetation that provides unobstructed views from nests;

- Distance of avocet nests to water range from 0 to $300 \mathrm{~m}$, although most nests are located within $60 \mathrm{~m}$ of water;

- $\quad$ Prefer islands for breeding and this may be due to greater protection from nest predators.
- Main foods taken by avocets are aquatic invertebrates of the water column and in sediment; also eat terrestrial invertebrates, small fish, and seeds;

- $\quad$ Ceratopogonidae (biting midges) and Chironomidae (nonbiting midges) were the dominant families of invertebrates eaten by avocets in migratory stopover sites in the Southern Great Plains;

- Avocets forage at various water depths, depending on age and bill length: Young (0-3 week-old)

chicks forage at water depths of 0 $90 \mathrm{~mm}$, but mainly at about $8 \mathrm{~mm}$. Older (3-6 week-old) chicks forage at depths from 0 to 100 $\mathrm{mm}$, but mostly at about $53 \mathrm{~mm}$. Adult females forage at $>80 \mathrm{~mm}$, and adult males forage at about $100 \mathrm{~mm}$. 


\begin{tabular}{lll}
\hline $\begin{array}{l}\text { Species } \\
\text { (common name) }\end{array}$ & Size of wetland or area & General habitats
\end{tabular}

- Three characteristics: open water, emergent vegetation, and open shoreline. Prefer to nest in moist sedge and rush meadows characterized by low plant height;

- Seasonal wetlands and

- Adjacent open water is also a habitat requirement;

habitats dominated by baltic • Nest site selection varies seasonally rush (Juncus balticus), sedges (Carex spp.), and grasses $<40 \mathrm{~cm}$ tall over semipermanent wetlands,

Wilson's Phalarope

- $\quad$ There is some evidence for area sensitivity;

- the species was rare in patches of CRP grassland that were $<100$ ha. habitats dominated by cattail and softstem bulrush (Schoenoplectus tabernaemontani) $>40 \mathrm{~cm}$ tall, saltgrass habitats, or upland shrub habitats. for this species. They nest in upland vegetation early in the breeding season and wet-meadow vegetation later in the season;

They usually nest $<100 \mathrm{~m}$ from shoreline;

- In Nebraska, habitat measurements around nests were $26-32 \mathrm{~cm}$ average height, 46-55 cm maximum vegetation height, 18-23 percent bare area, 99.9 percent grass cover, 3876-4385 stems $/ \mathrm{m}^{2}$ stem density, $0.74 \mathrm{~cm}$ litter depth, 4.2-4.6 $\mathrm{m}$ from water, $1.5 \mathrm{~mm}$ stem diameter, $829 \mathrm{~g} / \mathrm{m}^{2}$ above-ground biomass, $1.7 \mathrm{~cm}$ interstem distance, and 32-44 ha lake surface area.
- Main foods eaten by Wilson's phalaropes are small aquatic invertebrates (dipterans, crustaceans, particularly brine flies and brine shrimp) in freshwater or hypersaline environments;

- $\quad$ They also feed on some terrestrial invertebrates and occasionally on seeds of aquatic plants;

- $\quad$ Forage in open-water, flooded meadows, and less frequently in upland habitats and long beaches;

- Forages principally while swimming.
- Area-independent in their selection of wetlands.
- In Iowa, mean water depth in 71

- Across their breeding range, soras primarily use wetlands with shallow and intermediate water depths, dominated by robust or fineleaved emergent vegetation, especially cattails (Typha spp.), sedges (Carex spp., Cyperus spp.), burreeds (Sparganium spp.), and bulrushes (Scirpus spp.); breeding territories was $38.4 \mathrm{~cm} \pm$ 16.1 standard deviation (SD)(range 0-92) and was not significantly different from the Virginia rail (Rallus limicola);

- Mean vegetation height was 128.0 $\mathrm{cm} \pm 42.5 \mathrm{SD}$, and mean number of stems $/ \mathrm{m}^{2}$ in territories was 121.9 $\mathrm{cm} \pm 80.9 \mathrm{SD}$;

- $\quad$ Soras did not use areas where heavy snow, ice, and high water
- The main foods eaten by soras are the seeds of wetland plants and aquatic invertebrates;

- $\quad$ Proportion of invertebrates in their diet increases in the spring;

- Common plant foods include seeds of wild or cultivated rice, smartweeds, sedges, bulrushes, and grasses;

- Principal animal foods include adults, larvae, and pupae of a variety of aquatic insects (Orders 


\begin{tabular}{|c|c|c|c|c|}
\hline $\begin{array}{l}\text { Species } \\
\text { (common name) }\end{array}$ & Size of wetland or area & General habitats & Nesting/Breeding habitats & Foraging habitats \\
\hline $\begin{array}{l}\text { Sora } \\
\text { (continued) }\end{array}$ & & $\begin{array}{l}\text { - The Breeding Bird Atlas } \\
\text { Colorado (1998) reported } \\
\text { soras breeding in a variety of } \\
\text { wetlands in Colorado, } \\
\text { including cattail marshes, } \\
\text { grass or sedge marshes, wet } \\
\text { meadows, and irrigated } \\
\text { hayfields especially in } \\
\text { mountain parks; } \\
\text { Soras prefer cattails with } \\
\text { shallow water for breeding } \\
\text { and escape, and } 80 \text { percent } \\
\text { of Atlas reports came from } \\
\text { marshes, with cattails } \\
\text { usually the dominant } \\
\text { vegetation. }\end{array}$ & $\begin{array}{l}\text { had flattened emergent vegetation } \\
\text { until early May, new sedge growth } \\
\text { was } 20-30 \mathrm{~cm} \text { in height and } 80-100 \\
\text { stems } / \mathrm{m}^{2} \text { provided some cover. }\end{array}$ & $\begin{array}{l}\text { Coleoptera, Diptera, Hemiptera, } \\
\text { Odonata) and snails (Gastropoda); } \\
\text { Soras generally feed from a } \\
\text { standing position. In autumn, } \\
\text { soras strip seed heads of maturing } \\
\text { smartweeds and annual grasses; } \\
\text { They occasionally feed by } \\
\text { swimming in open water like a } \\
\text { coot; } \\
\text { - Stands of robust emergent } \\
\text { vegetation interspersed with } \\
\text { shorter, seed-producing } \\
\text { vegetation, and vegetative debris } \\
\text { that provides good substrate for } \\
\text { invertebrates near the water } \\
\text { surface; } \\
\text { May be attracted to shallower } \\
\text { portions of wetlands during brood- } \\
\text { rearing and premigration periods } \\
\text { where seed-producing plants such } \\
\text { as sedges, bulrushes, smartweeds, } \\
\text { beggarticks (Bidens spp.), and } \\
\text { grasses provide food; } \\
\text { In the late summer, soras may } \\
\text { leave wetlands for short periods to } \\
\text { feed in upland fields and row } \\
\text { crops. }\end{array}$ \\
\hline $\begin{array}{l}\text { White-faced } \\
\text { Ibis }\end{array}$ & - Not specified & $\begin{array}{l}\text { Prefer, almost exclusively, } \\
\text { areas with emergent } \\
\text { vegetation of some type; }\end{array}$ & $\begin{array}{l}\text { Usually nest in emergent vegetation } \\
\text { or low trees and shrubs over } \\
\text { shallow water, but can also nest on } \\
\text { the ground on small islands; }\end{array}$ & $\begin{array}{l}\text { Main foods taken are aquatic and } \\
\text { moist-soil insects, crustaceans, } \\
\text { and earthworms; } \\
\text { Forages in flooded hay meadows, } \\
\text { agricultural fields, and wetlands } \\
\text { (for example, pond and reservoir } \\
\text { margins, mudflats, and marshes) } \\
\text { with short, emergent vegetation; }\end{array}$ \\
\hline
\end{tabular}




\begin{tabular}{|c|c|c|c|c|}
\hline $\begin{array}{l}\text { Species } \\
\text { (common name) }\end{array}$ & Size of wetland or area & General habitats & Nesting/Breeding habitats & Foraging habitats \\
\hline $\begin{array}{l}\text { White-faced } \\
\text { Ibis (continued) }\end{array}$ & & $\begin{array}{l}\text { They inhabit primarily } \\
\text { freshwater wetlands and } \\
\text { marshes, especially those } \\
\text { containing cattail (Typha } \\
\text { spp.) and bulrush (Scirpus } \\
\text { spp.); } \\
\text { The landscape mosaic must } \\
\text { consist of wetlands that have } \\
\text { new vegetation growth and } \\
\text { that contain suitable water } \\
\text { levels (approximately } 1 \mathrm{~m} \text { in } \\
\text { the SLV, Colorado) from } \\
\text { late April through the end of } \\
\text { July to sustain ibises through } \\
\text { the breeding season. }\end{array}$ & $\begin{array}{l}\text { Ibises need some degree of } \\
\text { isolation by marshes or small } \\
\text { islands for both nesting colonies } \\
\text { and social night roosts; } \\
\text { At two locations in Utah all nests } \\
\text { were in hardstem bulrush or alkali } \\
\text { bulrush; } \\
\text { A nest's height, above the water or } \\
\text { ground, may vary depending upon } \\
\text { substrate type or other conditions; } \\
\text { In one Utah colony, nests ranged } \\
\text { from } 99.0-202.2 \text { cm above water } \\
\text { that was } 61 \text { cm deep; } \\
\text { The availability of feeding areas } \\
\text { within } 15-25 \text { km of breeding } \\
\text { colonies is a very important } \\
\text { landscape feature for the white- } \\
\text { faced ibis; } \\
\text { The importance of foraging areas } \\
\text { was demonstrated the summer of } \\
\text { 2003 at the Monte Vista NWR in } \\
\text { Colorado where nesting colonies } \\
\text { were deserted in the middle of the } \\
\text { breeding season. It is believed that } \\
\text { the primary reason for } \\
\text { abandonment and low reproduction } \\
\text { on the Refuge was due to the } \\
\text { minimal or lack of shallow-water } \\
\text { wet meadows where ibises forage. } \\
\text { Most ibises nesting in Colorado } \\
\text { favor tall emergent vegetation such } \\
\text { as bulrushes and cattails growing as } \\
\text { "islands” surrounded by water } \\
\text { more than } 45 \text { cm deep. }\end{array}$ & $\begin{array}{l}\text { Dominant plant species in } \\
\text { foraging areas generally are } \\
\text { sedges (Carex spp.), spikerushes } \\
\text { (Eleocharis spp.), salt-tolerant } \\
\text { grassworts (Salicornia spp.), } \\
\text { saltgrass (Distichlus stricta), and } \\
\text { greasewood (Sarcobatus } \\
\text { vermiculatus); } \\
\text { In Nevada, Colorado, Utah, Idaho, } \\
\text { California, and Oregon irrigated } \\
\text { crops of alfalfa, barley, and hay } \\
\text { are important feeding sites for } \\
\text { ibises; } \\
\text { In Nevada, white-faced ibises feed } \\
\text { in recently flooded agricultural } \\
\text { fields where vegetation is }<5 \text { to } 90 \\
\text { cm high, and they show a strong } \\
\text { preference for alfalfa fields. } \\
\text { Strong preferences were also } \\
\text { found for large (>30 ha), level (<5 } \\
\text { percent slope) fields with clay or } \\
\text { clay-loam soils and pools of } \\
\text { standing water; } \\
\text { Laubhan and Gammonley (2000) } \\
\text { speculated that differences in food } \\
\text { abundance, vegetation structure } \\
\text { and composition, and behavioral } \\
\text { strategies during the breeding } \\
\text { season, all influenced the ibis’ } \\
\text { selection of foraging habitats in } \\
\text { the SLV of Colorado. }\end{array}$ \\
\hline
\end{tabular}




\begin{tabular}{|c|c|c|c|c|}
\hline $\begin{array}{l}\text { Species } \\
\text { (common name) }\end{array}$ & Size of wetland or area & General habitats & Nesting/Breeding habitats & Foraging habitats \\
\hline Black Tern & $\begin{array}{l}\text { Preferred marshes } \\
\text { > } 20 \text { ha and only } \\
\text { rarely used smaller } \\
\text { marshes ( } 5 \text { ha } \\
\text { minimum) unless part } \\
\text { of larger wetland } \\
\text { complexes } \\
\text { In eastern South } \\
\text { Dakota, found that } \\
\text { terns nested in larger } \\
\text { basins and wetland } \\
\text { complexes; } \\
\text { The minimum area } \\
\text { requirement for the } \\
\text { black tern as a } \\
\text { semipermanent } \\
\text { wetland basin of } 12.4 \\
\text { ha. }\end{array}$ & $\begin{array}{l}\text { - Freshwater lakes, rivers, } \\
\text { other interior wetlands, } \\
\text { plowed fields, and coastal } \\
\text { wetlands; } \\
\text { More likely to occur in } \\
\text { wetlands with surrounding } \\
\text { grasslands that were }<50 \\
\text { percent tilled for agriculture. }\end{array}$ & $\begin{array}{l}\text { - Use a wide variety of vegetation } \\
\text { types in nesting areas; } \\
\text { Nests are usually built on floating } \\
\text { substrates of matted or decaying } \\
\text { marsh vegetation and often mixed } \\
\text { with mud; } \\
\text { Floating substrates can also be } \\
\text { detached root masses, logs and } \\
\text { boards, muskrat (Ondatra } \\
\text { zibethicus) feeding platforms or } \\
\text { clippings, algae or peat mats, lily } \\
\text { pads, dried cowpies, and old nests } \\
\text { of grebes, American Coots (Fulica } \\
\text { americana), and Forster's terns } \\
\text { (Sterna forsteri). These substrates } \\
\text { are usually anchored to or lodged in } \\
\text { emergent vegetation or dense beds } \\
\text { of submerged rooted aquatics; } \\
\text { Nonfloating substrates include } \\
\text { muskrat lodges, raised mud } \\
\text { patches, marshy hummocks, rooted } \\
\text { flattened vegetation, and upturned } \\
\text { tree roots with attached vegetation; } \\
\text { Nests can be particularly prone to } \\
\text { flooding; } \\
\text { In Colorado, black terns breed in } \\
\text { large cattail marshes next to open } \\
\text { water; } \\
\text { Rockwell (1911) described a nest at } \\
\text { Barr Lake as built on a dense carpet } \\
\text { of cattails blown over by the wind } \\
\text { about } 3 \text { m from shore in a sparsely } \\
\text { covered spot amid dense cattail } \\
\text { growth and over about } 15 \text { cm of } \\
\text { water, another on a large round top } \\
\text { of a duck blind floating in almost } \\
\text { waist deep water at the edge of } \\
\text { cattails in a small "rush-bound” } \\
\text { pond, and a third on a mass of dead }\end{array}$ & $\begin{array}{l}\text { Breeding black terns are mainly } \\
\text { insectivorous, but fish make up a } \\
\text { large part of the diet in some } \\
\text { habitats and regions; } \\
\text { - } \quad \text { Forage over freshwater lakes, } \\
\text { rivers, and other interior wetlands; } \\
\text { - They also forage over plowed } \\
\text { fields and coastal wetlands. }\end{array}$ \\
\hline
\end{tabular}




\begin{tabular}{|c|c|c|c|c|}
\hline $\begin{array}{l}\text { Species } \\
\text { (common name) }\end{array}$ & Size of wetland or area & General habitats & Nesting/Breeding habitats & Foraging habitats \\
\hline $\begin{array}{l}\text { Black Tern } \\
\text { (continued) }\end{array}$ & & & $\begin{array}{l}\text { floating cattails; } \\
\text { Nest semi-colonially, placing their } \\
\text { nests in clusters in favorable areas } \\
\text { of marshes; clusters are typically } \\
\text { about } 11-50 \text { nests but can range } \\
\text { from two to hundreds; } \\
\text { - Nests are usually } 5 \text { to } 20 \mathrm{~m} \text { apart, } \\
\text { but sometimes as close as } 1 \mathrm{~m} \text {; } \\
\text { - Up to } 25 \text { percent to } 30 \text { percent of } \\
\text { birds nest "solitarily," or from } 20 \text { to } \\
30 \text { m up to } 600 \text { m from other nests; } \\
\text { Generally select nest sites with an } \\
\text { approximate } 50: 50 \text { vegetation } \\
\text { cover to open water ratio that is } \\
\text { well interspersed with water. }\end{array}$ & \\
\hline
\end{tabular}

- $\quad$ No specific area requirements found although they "typically occur in large expanses of prairie or coastal grasslands, heathlands, shrubsteppe, and tundra."

- $\quad$ Require large (minimum 100 ha) tracts of land for successful nesting.

- Small mammals, particularly Microtus, are the main foods taken by short-eared owls;

- Most often in grasslands, prairies, and wetlands (68 percent of habitat observations), less commonly in shrublands, and rarely in scrub oak or pinyon-juniper woodlands.
- $\quad$ On the Great Plains, short-eared owls prefer to nest within large patches of relatively tall (30 to 60 $\mathrm{cm}$ ), dense, ungrazed grassland;

- Herkert and others (1999) in Illinois found that they required relatively short grass $(<50 \mathrm{~cm}$ tall) and most grasslands in the region needed to be mowed or burned to maintain this condition.
Less frequently, this species will hunt birds;

- Short-eared owls hunt primarily on the wing, approximately 0.3 to $3.0 \mathrm{~m}$ above ground;

- They also hover 2-30 m above ground or, less frequently, perched on poles or hills.
- Density of this species was

Brewer's Sparrow significantly correlated with total shrub cover, and capture rates were significantly
- Sagebrush-steppe obligate species;

- Throughout most of its range in the United States, it is most closely associated with landscapes dominated by big
- Breeds in shrublands and the average canopy height is usually $<1.5 \mathrm{~m}$;

- Compared with surrounding habitat, nests are located in significantly taller, denser shrubs
- The main foods taken by Brewer's sparrows are small insects, mainly gleaned from foliage and bark of shrubs and dwarf trees;

- Brewer's sparrows forage mostly in shrubs ( $>75$ percent of over 600 


\begin{tabular}{|c|c|c|c|c|}
\hline $\begin{array}{l}\text { Species } \\
\text { (common name) }\end{array}$ & Size of wetland or area & General habitats & Nesting/Breeding habitats & Foraging habitats \\
\hline $\begin{array}{l}\text { Brewer’s } \\
\text { Sparrow } \\
\text { (continued) }\end{array}$ & $\begin{array}{l}\text { correlated with shrub } \\
\text { cover and dead wood } \\
\text { cover; } \\
\text { They were positively } \\
\text { influenced by factors } \\
\text { indicating more } \\
\text { structurally complex } \\
\text { habitat; } \\
\text { Appear to be area- } \\
\text { sensitive, and isolated } \\
\text { stands of sagebrush } \\
\text { smaller than } 2 \text { ha are } \\
\text { not likely to be used } \\
\text { as nesting habitat. }\end{array}$ & $\begin{array}{l}\text { sagebrush (Artemisia } \\
\text { tridentata), where it is } \\
\text { usually the most abundant } \\
\text { bird species; } \\
\text { Also prefer small openings } \\
\text { (for example., }<1 \text { ha) of } \\
\text { short vegetation surrounded } \\
\text { by sagebrush. }\end{array}$ & $\begin{array}{l}\text { (primarily big sagebrush) with } \\
\text { reduced bare ground and } \\
\text { herbaceous cover; } \\
\text { Available cover may be the } \\
\text { primary factor in nest-site } \\
\text { selection; } \\
\text { - Nests are located toward the edge } \\
\text { of the densest portion of sagebrush } \\
\text { relative to nests of the sage sparrow } \\
\text { and the sage thrasher; } \\
\text { Brewer's sparrows prefer nest } \\
\text { shrubs to be entirely alive or mostly } \\
\text { alive } \\
\text { They have also been found nesting } \\
\text { in willow in Colorado. }\end{array}$ & $\begin{array}{l}\text { observation periods) and less on } \\
\text { open ground between shrubs or at } \\
\text { the base of bunchgrasses; } \\
\text { Shrubs selected by foraging } \\
\text { sparrows differ significantly from } \\
\text { those randomly available; they are } \\
\text { larger, more vigorous, and more } \\
\text { likely to consist of sagebrush } \\
\text { rather than green (Chrysothamnus } \\
\text { viscidiflora) or gray (C. } \\
\text { nauseosus) rabbitbrush. }\end{array}$ \\
\hline $\begin{array}{l}\text { Savannah } \\
\text { Sparrow }\end{array}$ & $\begin{array}{l}\text { - } \\
\text { Area-incidence } \\
\text { functions indicated } \\
\text { that savannah } \\
\text { sparrows require open } \\
\text { areas of 10-15 ha in } \\
\text { grasslands and } \\
\text { blueberry barrens; } \\
\text { In South Dakota, } \\
\text { savannah sparrows } \\
\text { were found to be } \\
\text { area-sensitive and } \\
\text { used only large } \\
\text { grassland patches. }\end{array}$ & $\begin{array}{l}\text { In Colorado, croplands, } \\
\text { montane grassland, and } \\
\text { emergent marshes accounted } \\
\text { for } 58 \text { percent of habitats } \\
\text { reported. Salt meadows, } \\
\text { mountain sagebrush, } \\
\text { montane carr, and willow } \\
\text { carr made up another } 22 \\
\text { percent of sightings; } \\
\text { Irrigated hay meadows are } \\
\text { an important component of } \\
\text { savannah sparrow habitats in } \\
\text { mountain parks and western } \\
\text { valleys in Colorado. }\end{array}$ & $\begin{array}{l}\text { Breeding range habitat is open } \\
\text { country including grassy meadows, } \\
\text { cultivated fields (especially alfalfa), } \\
\text { lightly grazed pastures, roadsides, } \\
\text { coastal grasslands, sedge bogs, } \\
\text { edge of salt marshes, and tundra; } \\
\text { They avoid areas with extensive } \\
\text { tree cover, generally occurring in } \\
\text { fields with some herbaceous plants } \\
\text { or weeds; } \\
\text { In arid parts of their range, they are } \\
\text { generally restricted to irrigated } \\
\text { areas or to the grassy margins of } \\
\text { ponds; } \\
\text { Savannah sparrows prefer dense } \\
\text { ground vegetation, especially } \\
\text { grasses, and moist microhabitats } \\
\text { are favored; } \\
\text { In Colorado, moist, grassy, } \\
\text { mountain meadows are favored } \\
\text { breeding habitats, but irrigated hay } \\
\text { meadows and alfalfa are also } \\
\text { important throughout Colorado. }\end{array}$ & $\begin{array}{l}\text { During the breeding season, } \\
\text { primarily forage on adult and } \\
\text { larval insects, spiders, seeds and } \\
\text { fruits; } \\
\text { Occasionally, they will eat insect } \\
\text { eggs, millipedes, isopods, } \\
\text { amphipods, decapods, mites, and } \\
\text { small mollusks; } \\
\text { Mainly forages on the ground in } \\
\text { short vegetation in pastures, sedge } \\
\text { bogs, tundra, beach wrack, mud } \\
\text { flats (near cover), and dunegrass; } \\
\text { In winter, they forage primarily on } \\
\text { small seeds of grasses and other } \\
\text { herbs, small-seeded fruits, insects, } \\
\text { and spiders. }\end{array}$ \\
\hline
\end{tabular}




\begin{tabular}{|c|c|c|c|c|}
\hline $\begin{array}{l}\text { Species } \\
\text { (common name) }\end{array}$ & Size of wetland or area & General habitats & Nesting/Breeding habitats & Foraging habitats \\
\hline $\begin{array}{l}\text { Northern } \\
\text { Leopard Frog }\end{array}$ & $\begin{array}{l}\text { No specific area } \\
\text { requirements found, } \\
\text { but because NLFs } \\
\text { have a complicated } \\
\text { life history, they } \\
\text { require a broad range } \\
\text { of habitats in close } \\
\text { proximity; } \\
\text { Three categories of } \\
\text { major habitat type } \\
\text { were described by } \\
\text { Merrell and Rodell } \\
\text { (1968): winter habitat } \\
\text { (overwintering in } \\
\text { lakes, streams, and } \\
\text { ponds); summer } \\
\text { habitat (feeding by } \\
\text { adults in upland } \\
\text { areas); and, tadpole } \\
\text { habitat (up to three } \\
\text { months spent as } \\
\text { tadpoles in shallow } \\
\text { breeding ponds); } \\
\text { Their complicated } \\
\text { movement patterns } \\
\text { during the year } \\
\text { should also be } \\
\text { considered; } \\
\text { Prefer smaller (less } \\
\text { than } 5 \text { ha) seasonal } \\
\text { and semi-permanent } \\
\text { ponds. }\end{array}$ & $\begin{array}{l}\text { Typical habitats described } \\
\text { in Colorado include wet } \\
\text { meadows and the banks and } \\
\text { shallows of marshes, ponds, } \\
\text { glacial kettle ponds, beaver } \\
\text { ponds, lakes, reservoirs, } \\
\text { streams, and irrigation } \\
\text { ditches; } \\
\text { Adult NLFs are usually } \\
\text { found at the water's edge, } \\
\text { but they may roam far from } \\
\text { permanent water during } \\
\text { mild wet weather; } \\
\text { Winter months are spent at } \\
\text { the bottom of water bodies } \\
\text { such as ponds and streams; } \\
\text { Adult NLFs typically avoid } \\
\text { upland areas that have grass } \\
\text { cover one meter tall, } \\
\text { wooded areas, open areas } \\
\text { lacking vegetation, and in } \\
\text { heavily grazed or mowed } \\
\text { areas. }\end{array}$ & $\begin{array}{l}\text { - NLFs breed in shallow, quiet areas } \\
\text { of permanent bodies of water, in } \\
\text { beaver ponds, and in seasonally } \\
\text { flooded areas adjacent to or } \\
\text { contiguous with permanent pools or } \\
\text { streams; } \\
\text { Breeding areas contain vegetation, } \\
\text { mats of algae, and clear water; } \\
\text { They use small (usually } \leq 5 \text { ha) } \\
\text { ponds in which to breed; } \\
\text { Egg masses are attached to } \\
\text { vegetation just below the surface of } \\
\text { warm shallows about } 7 \text { to } 25 \mathrm{~cm} \\
\text { deep; } \\
\text { At elevations of } 1,570 \text { to } 2,520 \mathrm{~m} \\
\text { in Colorado and southern } \\
\text { Wyoming, egg masses average } \\
\text { about 3,000 eggs (range } 645- \\
6,272 \text { ). }\end{array}$ & $\begin{array}{l}\text { - There is little information on the } \\
\text { food habits of the NLF in } \\
\text { Colorado; however, invertebrates } \\
\text { most likely dominate the diet of } \\
\text { adult frogs; } \\
\text { - Gehlback (1965) reported that } \\
\text { NLFs ate tenebrionid beetles in } \\
\text { northwestern New Mexico; } \\
\text { - } \text { Drake (1914) studied the food } \\
\text { habits of NLFs in Ohio and found } \\
\text { that the diet consisted of molluscs, } \\
\text { crustaceans, spiders, and insects; } \\
\text { They use moist upland habitats } \\
\text { surrounding their breeding ponds } \\
\text { for summertime foraging }\end{array}$ \\
\hline
\end{tabular}




\begin{tabular}{|c|c|c|c|c|}
\hline $\begin{array}{l}\text { Species } \\
\text { (common name) }\end{array}$ & Size of wetland or area & General habitats & Nesting/Breeding habitats & Foraging habitats \\
\hline $\begin{array}{l}\text { Tadpole } \\
\text { Shrimp }\end{array}$ & $\begin{array}{l}\text { - No area requirements } \\
\text { found in the } \\
\text { literature. }\end{array}$ & $\begin{array}{l}\text { Rely on seasonal wetlands, } \\
\text { salt flats, and alkali pans, } \\
\text { permanent playas, fishless } \\
\text { alkali lakes, and salt lakes; } \\
\text { These habitats are, for the } \\
\text { most part, seasonal pools } \\
\text { that are dry for a significant } \\
\text { portion of the year, or } \\
\text { several years; } \\
\text { Young tadpole shrimp } \\
\text { typically inhabit the surface } \\
\text { areas of ephemeral pools, } \\
\text { whereas older individuals } \\
\text { are usually benthic. }\end{array}$ & $\begin{array}{l}\text { - Rely on banks of resting eggs } \\
\text { (or “cysts”) to bridge periods } \\
\text { of drought or frost and buffer } \\
\text { against the effects of } \\
\text { environmental variability; } \\
\text { The eggs lay dormant in the } \\
\text { substrate until the pool dries } \\
\text { and refills during subsequent } \\
\text { rains; } \\
\text { In the temporally fluctuating } \\
\text { environment of temporary } \\
\text { aquatic habitats, usually only a } \\
\text { portion of the dormant eggs, if } \\
\text { any, hatch during each } \\
\text { flooding period; } \\
\text { This process can lead to the } \\
\text { generation of an egg bank that } \\
\text { can remain viable for decades } \\
\text { or possibly centuries without } \\
\text { rehydration. }\end{array}$ & $\begin{array}{l}\text { Predominantly benthic and } \\
\text { omnivorous, feeding on detritus } \\
\text { and living or dead organisms; } \\
\text { They are also known to feed on } \\
\text { mosquito larvae, amphibian } \\
\text { tadpoles, mayflies (Callibaetis } \\
\text { californicus), and rice seedlings. }\end{array}$ \\
\hline
\end{tabular}

Publishing support provided by:

Denver Publishing Service Center

For more information concerning this publication, contact:

Center Director, USGS Fort Collins Science Center

2150 Centre Ave., Bldg. C

Fort Collins, CO 80526-8118

(970) 226-9398

Or visit the Fort Collins Science Center Web site at:

http://www.fort.usgs.gov/ 